Universidad deValladolid

PROGRAMA DE DOCTORADO EN

INVESTIGACIÓN EN CIENCIAS DE LA SALUD

TESIS DOCTORAL:

Evaluación del uso de una dosis de vacuna oral inactivada como respuesta

a la epidemia de cólera en Zambia y posterior administración de la segunda dosis (8 meses después) para incrementar la duración de la protecclón vacunal.

Presentada por EVA FERRERAS BARRERA para optar al grado de

Doctora por la Universidad de Valladolid

Dirigida por:

FRANCISCO JAVIER LUQUERO ALCALDE $Y$ JOSE MARIA EIROS BOUZA 

A mi madre y a mi padre 

AGRADECIMIENTOS 

El trabajo presentado en esta tesis esta hecho con convicción, esfuerzo, constancia, ilusión y amor. Valores que aprendí de mis abuelas, abuelos y bisabuelas que llevo dentro de mi corazón.

Gracias a mis padres y familia por vuestro sostén y amor infinito. Gracias Mari por todo el apoyo logistico durante mi carrera académica (y muchas otras cosas más).

Agradecida a mis años en el Centro Nacional de Epidemiología, por ser mi punto de partida para convertirme en epidemióloga y por los buenos años compartidos. En especial a Dionisio Herrera, Fernando Simón, Marivi Martinez de Aragón, Nuria Aragonés, Gemma Molist, Diana Gómez y Olivier Nuñez. Gracias por darme estructura para volar.

Gracias Mariajo, Teresa, Yedra y Txuri por vuestra amistad y sororidad durante el camino. ¡Y a Sara por ese empujón final!.

Gracias José María Eiros por tu tesón y cariño guiando este viaje a buen puerto.

Gracias Fran Luquero por reconocerme, por tu mentorización y apoyo académico. Y por todos los valores profesionales y personales que he aprendido a lo largo de estos años.

Grand merci à mes colleagues pour le partage des conaissances tequniques et leur amitié sans frontières: Alex Blake, Marc Poncin, Christel Saussier and Andrew Azman. Nous sommes ensemble dans la lutte!.

This project could not have been possible without the the support of the Ministry of Health of Zambia, MSF-OCG, JHU and WHO. Especial thanks to Guideon Zulu and Clara Mwili from the Lusaka District Health Office. I also want to thank the MSF-OCG for their financial, logistical and human support during the vaccine effectiveness study and WHO for the financial support for the systematic review and the coverage survey.

Je suis très reconnaissante à Marie-Laure Quilici et Jean Rauzier pour leur soutien au niveau du renforcement des capacités pour le lancement de la PCR lors du projet en Zambie et pour la formation qu'il m'ont donnée au sein du Centre National De Référence des Bacteries pathogènes entériques, à l'Institut Pasteur à Paris. 
I would like to thank my colleagues, study teams and MSF team in Lusaka: especially Marc Poncin, Jean-Guy Audéoud, Sarah St-Arnaud and Ankur Rakesh for their support and enthusiasm provided enabling the fieldwork to run smoothly. I wish to express my gratitude to John Mwamba, Orbrie Chewie, Hannah Mzyece and Loveness Moonde for their commitment during the culture capacity building at Kanyama Health Clinic, the field supervision and leadership to the field teams. And to the national field work team for their intense and excellent work: especially to Lawrence Mtenge, Melody Kalombo and Christine Zulu.

Finally, I would like to express my deepest gratitude to all people we interviewed for their generosity and patience. 


\section{LISTA DE SIGLAS Y ACRÓNIMOS}

Ac: Anticuerpos

Ag: Antígeno

APC: Células presentadoras de antígenos

APW: Agua peptonada alcalina

BivWC: Vacuna inactivada bivalente con células enteras inactivadas de Vibrio cholerae 01 y 0139

CC: Caso-cohorte

CFTR: Regulador de la conductancia transmembrana de la fibrosis quística

CHOVI: Programa "Iniciativa de Vacunas de Cólera"

CT: Toxina colérica

CTC: Centros de tratamiento de cólera

CTX: Bacteriofago filamentoso

CV: Cobertura vacunal

DS: Desviación stándar

ECA: Ensayo clínico aleotorizado

EV: Efectividad vacunal

FICR: Federación Internacional de la Cruz Roja y Sociedades de la Media Luna Roja

GTFCC: Grupo de Trabajo Global para el Control del Cólera

HR: Cociente de riesgo

IC: Intervalo de confianza

ICG: Grupo Coordinador Internacional

IQR: Rango intercuartílico

IVI: Instituto International de Vacuna

JMP: Programa Conjunto de Monitoreo del Abastecimiento del Agua, el

Saneamiento y la Higiene

LPS: lipopolisacárido

MCC: Casos y controles pareado

MH: Mueller- Hinton

MICE: Imputación multiple por ecuaciones encadenadas

MS: Ministerio de Salud de Zambia 
MSF: Médicos sin Fronteras

OCV: Vacunas orales inactivadas

OMS: Organización Mundial de la Salud

OR: Odds ratio

PCR: Reacción en cadena de la polimerasa

PRISMA: Preferred Reporting Items for Systematic reviews and Meta-analyses for Protocols

RDT: Test de diagnóstico rápido

RR: Riesgo relativo

sIgA: Inmunoglobulina A secretora

TCBS: Agar tiosulfato-citrato-bilis-sacarosa

TCP: Pili corregulado con la toxina

TNCC: Test-negativo de casos y controles

UNICEF: Fondo Internacional de Emergencia de las Naciones Unidas para la Infancia

USA: Estados Unidos de América

UTH: Hospital Universitario de Lusaka

VPI: Isla de patogenicidad de Vibrio

VSP: Vibrio seventh pandemic

WC-rBS: Vacuna inactivada monovalente con células enteras inactivadas de Vibrio cholerae 01 y subunidad B de toxina colérica recombinante

WHA: World Health Assembly

Zambia: República de Zambia 


\section{ÍNDICE DE CAPITULOS}

SUMMARY

RESUMEN

1 INTRODUCCIÓN

1.1 Origen, aspectos generales y carga de la enfermedad.

1.2 Genética del Vibrio cholerae

1.3 Biología Molecular de la toxina colérica

1.4 Respuesta inmunológica al Vibrio cholerae

1.5 Vacunas y uso en los últimos años

1.5.1 Dukoral ${ }^{\circledR}$

1.5.2 mORC-VAX ${ }^{\mathrm{TM}}$ y Shanchol ${ }^{\mathrm{TM}}$

1.5.3 Euvichol ${ }^{\circledR}$

1.5.4 OraVacs $^{\mathrm{TM}}$

1.5.5 Vaxchora $^{\mathrm{TM}}$

1.6 Contexto: Zambia

1.7 Cólera en Zambia

2 JUSTIFICACIÓN

3 OBJETIVOS

3.1 Objetivo general 
4.1 Marco y diseño general del proyecto de investigación

4.2 Revisión sistemática y meta-análisis de vacunas inactivadas orales $\begin{array}{ll}\text { frente al cólera } & \mathbf{6 0}\end{array}$

4.2.1 Estrategia de búsqueda y criterios de selección. 60

$\begin{array}{ll}4.2 .2 \text { Definiciones } & 60\end{array}$

$\begin{array}{lll}\text { 4.2.3 Análisis de los datos } & 61\end{array}$

$\begin{array}{lll}4.3 & \text { Población objeto de estudio } & 63\end{array}$

$\begin{array}{lll}4.4 & \text { Estudio de eficacia vacunal de una dosis }\end{array}$

$\begin{array}{ll}\text { 4.4.1 Vigilancia de cólera } & 64\end{array}$

4.4.2 Diseño del estudio $\quad 65$

4.4.3 Definición y selección de los participantes del estudio 66

4.4.4 Procedimiento del estudio 68

4.4.5 Verificación del estado vacunal y de variables potencialmente confusoras.

4.4.6 Procedimientos de laboratorio $\quad 69$

$\begin{array}{lll}4.4 .7 & \text { Análisis estadístico } & 71\end{array}$

4.4.7.1 Análisis de casos y controles (MCC y TNCC) 72

4.4.7.2 Análisis de caso-cohorte $\quad 72$

$\begin{array}{ll}\text { 4.4.7.3 Análisis de indicador de sesgo } & 73\end{array}$

$\begin{array}{ll}\text { 4.4.7.4 Análisis de datos faltantes (missings) } & 74\end{array}$

4.5 Encuesta de cobertura de la campaña de vacunación.

$\begin{array}{ll}\text { 4.5.1 Diseño del estudio } & 74\end{array}$

$\begin{array}{ll}\text { 4.5.2 Recogida de datos } & 75\end{array}$

$\begin{array}{lll}\text { 4.5.3 Análisis de los datos } & 76\end{array}$

4.6 Herramientas para la recogida y análisis de los datos 77 
5.1 Revisión sistemática y meta-análisis de vacunas inactivadas orales $\begin{array}{ll}\text { frente al cólera } & 81\end{array}$

5.1.1 Descripción de los ensayos clínicos 82

5.1.2 Descripción de los estudios observacionales 83

5.1.3 Estimaciones con el esquema de dos dosis 85

5.1.4 Estimaciones con el esquema de una dosis 87

5.1.5 Estimaciones con el esquema de tres dosis 88

5.1.6 Duración de la protección 89

$\begin{array}{ll}5.1 .7 & \text { Estimaciones por grupo de edad }\end{array}$

5.2 Descripción del brote de cólera de 2016 en Zambia 92

5.3 Descripción de la campaña de vacunación con vacuna oral frente al cólera de 2016.

5.4 Encuesta de cobertura vacunal después de la primera dosis. 94

5.4.1 Descripción de la muestra y cobertura vacunal global 94

5.4.2 Cobertura vacunal por municipios 95

5.4.3 Coberturas vacunales por edad y sexo 96

5.5 Evaluación de la efectividad vacunal $\quad 97$

5.5.1 Características basales de los participantes del estudio. 97

5.5.2 Descripción de las características de los casos sospechosos y confirmados

5.5.3 Descripción de los casos confirmados y sus controles pareados 98

5.5.4 Descripción de las caracteristicas de los participantes de la cohorte 100

$\begin{array}{ll}\text { 5.5.5 Análisis de eficacia vacunal } & 101\end{array}$

5.5.5.1 Análisis con el diseño de casos y controles pareado 101

5.5.5.2 Análisis con el diseño de test-negativo de casos y controles 103

5.5.5.3 Análisis con el diseño de caso-cohorte 103

5.5.5.4 Análisis estratrificado por edad, severidad y área seleccionada para la $\begin{array}{ll}\text { campaña de vacunación. } & 104\end{array}$

$\begin{array}{ll}\text { 5.5.6 Análisis de indicador de sesgo } & 105\end{array}$ 
5.5.7 Factores de confusión y de modificación de efecto: Selección del modelo para el estimador ajustado. 105

$\begin{array}{ll}\text { 5.5.7.1 Diseño de casos y controles pareado } & 105\end{array}$

5.5.7.2 Diseño de test-negativo de casos y controles 107

$\begin{array}{ll}\text { 5.5.7.3 Diseño de caso-cohorte } & 107\end{array}$

$\begin{array}{ll}\text { 5.5.8 Valores faltantes } & 111\end{array}$

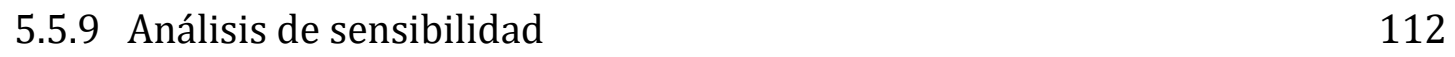

5.5.9.1 Análisis de sensibilidad considerando el estado vacunal. 112

5.5.9.2 Análisis de sensibilidad considerando la distancia entre el caso y su control 113

5.6 Encuesta de cobertura al final de la campaña de vacunación con 0CV.115

$\begin{array}{ll}\text { 5.6.1 Descripción de la muestra } & 115\end{array}$

5.6.2 Segunda ronda de vacunación: Diciembre de $2016 \quad 116$

5.6.3 Primera ronda de vacunación: Abril de 2016116

5.6.4 Cobertura vacunal global con dos dosis y con una dosis única 117

$\begin{array}{ll}\text { 5.6.5 Análisis estratificado } & 117\end{array}$

$\begin{array}{ll}\text { 5.6.6 Causas del rechazo a la vacunación } & 121\end{array}$

$\begin{array}{ll}\text { 5.6.7 Eventos adversos después de la inmunización. } & 121\end{array}$

6 DISCUSIÓN 125

6.1 Revisión sistemática y meta-análisis de vacunas inactivadas orales $\begin{array}{lr}\text { frente al cólera. } & 125\end{array}$

6.2 Evaluación de la efectividad vacunal con una dosis 128

6.3 Encuesta de cobertura de la campaña de vacunación. 133

7 CONCLUSIONES Y RECOMENDACIONES $\quad 139$

$\begin{array}{llr}7.1 & \text { Revisión sistemática y metaanálisis } & 139\end{array}$

7.2 Efectividad vacunal a corto plazo con una dosis de vacuna 140 
7.3 Cobertura vacunal de la campaña con una pauta de dos dosis de vacuna administradas de forma tardía

8.1 Systematic review and meta-analysis of killed whole-cell oral cholera vaccines

8.2 Short-term effectiveness of a single-dose of OCV

9 BIBLIOGRAFÍA

- Protection against cholera from killed whole-cell oral cholera vaccines: a systematic review and meta-analysis.

- Single-Dose Cholera Vaccine in Response to an Outbreak in Zambia.

- Delayed second dose of oral cholera vaccine administered before high-risk period for cholera transmission: Cholera control strategy in Lusaka, 2016.

- Evaluation of the SD bioline cholera rapid diagnostic test during the 2016 cholera outbreak in Lusaka, Zambia.

- Alternative observational designs to estimate the effectiveness of one dose of oral cholera vaccine in Lusaka, Zambia.

10.2 Anexo 2. Listado de enfermedades bajo vigilancia semanal e incluida en el sistema de alerta temprana de Zambia 
10.5 Anexo 5. Cuestionarios $\quad 264$

10.5.1Cuestionario general estudio de eficacia vacunal 265

10.5.2 Cuestionario de seguimiento de la cohorte 273

10.5.3 Cuestionario de la encuesta de cobertura vacunal 274 


\section{TABLE OF CONTENT}

SUMMARY

RESUMEN

1 INTRODUCTION

1.1 Origin, general features and disease burden

1.2 Genetics of Vibrio cholerae

1.3 Molecular Biology of cholera toxin

1.4 Inmune response to Vibrio cholerae

1.5 Cholera vaccines and use over recent years

1.5.1 Dukoral ${ }^{\circledR}$

1.5.2 mORC-VAX $^{\mathrm{TM}}$ and Shanchol ${ }^{\mathrm{TM}}$

1.5.3 Euvichol ${ }^{\circledR}$

1.5.4 OraVacs $^{\text {TM }}$

1.5.5 Vaxchora $^{\mathrm{TM}}$ 
4.2 Systematic review and meta-analysis of killed whole-cell oral cholera vaccines

$\begin{array}{ll}\text { 4.2.1 Search strategy and selection criteria } & 60\end{array}$

$\begin{array}{ll}4.2 .2 \text { Definitions } & 60\end{array}$

$\begin{array}{lll}4.2 .3 \text { Data analysis } & 61\end{array}$

$\begin{array}{lll}4.3 & \text { Study population } & 63\end{array}$

$\begin{array}{lll}4.4 & \text { One dose vaccine effectiveness study }\end{array}$

$\begin{array}{lll}\text { 4.4.1 Cholera surveillance } & 64\end{array}$

$\begin{array}{ll}4.4 .2 \text { Study design } & 65\end{array}$

4.4.3 Definition and selection of cases 66

$\begin{array}{ll}\text { 4.4.4 Study procedures } & 68\end{array}$

4.4.5 Ascertainment of vaccination status and potentially confounding $\begin{array}{ll}\text { variables } & 68\end{array}$

$\begin{array}{ll}\text { 4.4.6 Laboratory procedures } & 69\end{array}$

$\begin{array}{ll}\text { 4.4.7 Statistical analysis } & 71\end{array}$

$\begin{array}{lll}\text { 4.4.7.1 Case-control analysis (MCC and TNCC) } & 72\end{array}$

$\begin{array}{lll}\text { 4.4.7.2 Case-cohort analysis } & 72\end{array}$

$\begin{array}{lll}\text { 4.4.7.3 Bias indicator analysis } & 73\end{array}$

$\begin{array}{lll}\text { 4.4.7.4 Missing data } & 74\end{array}$

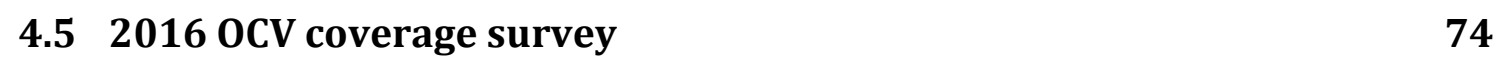

$\begin{array}{ll}4.5 .1 \text { Study design } & 74\end{array}$

$\begin{array}{lll}\text { 4.5.2 Data collection } & 75\end{array}$

$\begin{array}{lll}\text { 4.5.3 Data analysis } & 76\end{array}$

$\begin{array}{ll}4.6 & \text { Tools for data collection and analysis }\end{array}$ 
5.1 Systematic review and meta-analysis of killed whole-cell oral cholera vaccines

5.1.1 Clinical trials description 82

5.1.2 Observational studies description 83

5.1.3 Two-doses estimations 85

$\begin{array}{lll}5.1 .4 & \text { One-dose estimations } & 87\end{array}$

5.1.5 Three-doses estimations 88

5.1.6 Protection duration $\quad 89$

$\begin{array}{lll}5.1 .7 & \text { Estimations by age-group } & 90\end{array}$

5.2 Description of the 2016 cholera epidemic in Lusaka 92

5.3 Description of the 2016 vaccination campaign with OCV 93

5.4 Coverage survey after the first round 94

5.4.1 Sample description and overall vaccine coverage 94

5.4.2 Vaccine coverage by townships 95

5.4.3 Vaccine coverage by age and sex 96

5.5 One-dose vaccine Effectiveness 97

5.5.1 Baseline characteristics of the study population 97

5.5.2 Characteristics of suspected and confirmed cholera cases 98

5.5.3 Characteristics of confirmed cholera cases and controls. 98

$\begin{array}{ll}\text { 5.5.4 Characteristics of cohort members } & 100\end{array}$

$\begin{array}{ll}\text { 5.5.5 Vaccine effectiveness anyalisis } & 101\end{array}$

$\begin{array}{lll}\text { 5.5.5.1 Matched case-control analysis } & 101\end{array}$

5.5.5.2 Test-negative case-control analysis 103

$\begin{array}{lll}\text { 5.5.5.3 Case-cohort analysis } & 103\end{array}$

5.5.5.4 Main case control analysis stratified by age, severity and vaccinated area 104

$\begin{array}{ll}\text { 5.5.6 Bias indicator analysis } & 105\end{array}$

5.5.7 Model selection for the multivariate analysis: Adjustment for confounder $\begin{array}{ll}\text { and effect modifier. } & 105\end{array}$

$\begin{array}{lll}\text { 5.5.7.1 Matched case-control analysis } & 105\end{array}$

$\begin{array}{lll}\text { 5.5.7.2 Test-negative case-control analysis } & 107\end{array}$ 
$\begin{array}{ll}\text { 5.5.8 Missing data } & 111\end{array}$

$\begin{array}{ll}\text { 5.5.9 Sensitive analysis } & 112\end{array}$

$\begin{array}{lll}\text { 5.5.9.1 Sensitive analysis considering vaccination status } & 112\end{array}$

5.5.9.2 Sensitive analysis considering the distance between the control and their case 113

5.6 Coverage survey at the end of OCV campaign 115

$\begin{array}{ll}\text { 5.6.1 Sample description } & 115\end{array}$

5.6.2 Second vaccination round: December $2016 \quad 116$

5.6.3 First vaccination round: Abril de $2016 \quad 116$

5.6.4 Overall two dose and single dose vaccination coverage 117

5.6.5 Stratified analysis by age, sex and township 117

$\begin{array}{ll}\text { 5.6.6 Reasons for non-vaccination } & 121\end{array}$

$\begin{array}{ll}\text { 5.6.7 Adverse events following immunization } & 121\end{array}$

6 DISCUSSION 125

6.1 Systematic review and meta-analysis of killed whole-cell oral cholera $\begin{array}{lr}\text { vaccines } & 125\end{array}$

\begin{tabular}{ll}
6.2 & One-dose vaccine Effectiveness \\
\hline
\end{tabular}

6.3 Coverage survey at the end of OCV campaign 133

8 CONCLUSIONS AND RECOMENDATIONS 145

8.1 Systematic review and meta-analysis of killed whole-cell oral cholera $\begin{array}{ll}\text { vaccines } & 145\end{array}$

8.2 Short-term effectiveness of a single-dose of OCV 145

8.3 Coverage survey of the 2016 oral cholera vaccination campaign $\quad 147$

9 REFERENCES 
- Protection against cholera from killed whole-cell oral cholera vaccines: a systematic review and meta-analysis.

- Single-Dose Cholera Vaccine in Response to an Outbreak in Zambia.

- Delayed second dose of oral cholera vaccine administered before high-risk period for cholera transmission: Cholera control strategy in Lusaka, 2016.

- Evaluation of the SD bioline cholera rapid diagnostic test during the 2016 cholera outbreak in Lusaka, Zambia.

- Alternative observational designs to estimate the effectiveness of one dose of oral cholera vaccine in Lusaka, Zambia.

10.2 Anexo 2. List of priority diseases under weekly surveillance included in the Zambia early warning system

10.3 Anexo 3. Informed consents

10.3.1 Informed consent for adults

10.3.2 Informed consent for gardians

10.3.3 Assent form for minors

10.5.1 General questionnaire for vaccine effectiveness study

10.5.2 Cohort follow-up questionnaire 



\section{ÍNDICE DE TABLAS}

Tabla 1. Diversidad del $V C$ en el medio ambiente. .26

Tabla 2. Características fenotípicas y genotípicas de cepas $V C 01$ 31

Tabla 3. Resumen de los estudios de eficacia vacunal que cumplían los criterios de inclusión en su análisis principal

Tabla 4. Resumen de los estudios de efectividad vacunal que cumplían los criterios de inclusión en su análisis principal .84

Tabla 5. Resúmen del riesgo de sesgos de los estudios obervacionales .85

Tabla 6. Cobertura administrativa de la primera ronda de vacunación .94

Tabla 7. Cobertura administrativa de la segunda ronda de vacunación. .94

Tabla 8. Coberturas vacunales por municipios .95

Tabla 9. Presentación clínica y tratamiento de los casos sopechosos de cólera......98

Tabla 10. Características de los pacientes con cólera, pacientes con diarrea no colérica y sus controles pareados.

Tabla 11. Características de los participantes de la cohorte y los casos confirmados.

Tabla 12. Estimaciones de efectividad vacunal cruda y ajustada.

Tabla 13. Análisis estratificados por edad, severidad de la enfermedad y área seleccionada por la campaña para la vacunación

Tabla 14. Análisis de indicador de sesgo

Tabla 15. Características de los vacunados y los no vacunados según el diseño.106

Tabla 16. Características de los vacunados y no vacunados en el diseño de caso-cohorte

Tabla 17. Resúmen de las varibales incluidas en los modelos multivariados 110

Tabla 18. Porcentaje de valores faltantes de las variables analizadas como posibles factores de confusión

Tabla 19. Estimaciones ajustadas de la EV considerando diversas estrategias de manejo de datos faltantes y por diseño.

Tabla 20. Análisis de sensibilidad del estado vacunal excluyendo a los individuos sin carné de vacunación y considerando los individuos sin carné como vacunados 
Tabla 21. Análisis de sensibilidad del estado vacunal en los paticipantes que vivían en las áreas objeto de la campaña de vacunación excluyendo los pares cuya distancia entre el control y su caso era de más de $150 \mathrm{~m}$, más de 300m y sin exclusión de distancia.

Tabla 22. Motivos de rechazo a participar en la encuesta........................................... 115

Tabla 23. Cobertura vacunal (CV) por grupo de edad, sexo y municipio .................118

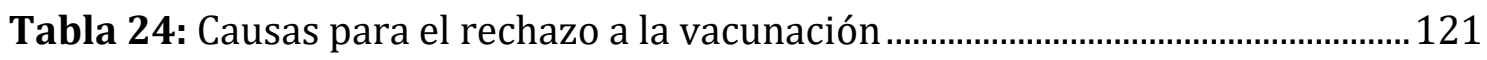

Tabla 25. Eventos adversos reportados después de la inmunización ....................... 122 


\section{ÍNDICE DE FIGURAS}

Figura 1. Presentación clínica y deposiciones coléricas.................................................23

Figura 2. Mecanismos de transmisión seguidos por VC ...............................................25

Figura 3. Casos anuales de cólera en países endémicos.................................................26

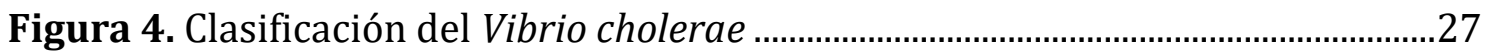

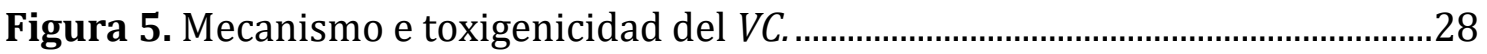

Figura 6. Estructura del CTX y el RS1 en diferentes variantes del VC $01 \ldots \ldots \ldots \ldots \ldots . . . . .29$

Figura 7. Representación de la estructura molecular de la toxina colérica.................31

Figura 8. Mecanismo de acción de la toxina colérica............................................................33

Figura 9. Progresión de Ac después de la infección por Vibrio cholerae......................35

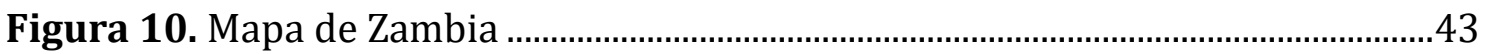

Figura 11. Curvas epidémicas de cólera en Lusaka durante el periodo

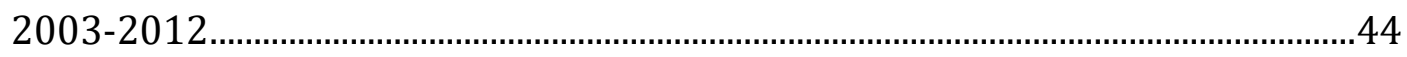

Figura 12. Diagrama resumen del diseño del proyecto de investigación.....................59

Figura 13. Áreas perceptoras de la campaña masiva de vacunación frente al cólera en Lusaka, Zambia, 2016 y coberturas administrativas.

Figura 14. Mapa de Lusaka por municipios

Figura 15. Descripción de las diferentes muestras recogidas para cultivo, test rápido y análisis de $\mathrm{PCR}$

Figura 16. Diagrama de flujo PRISMA con los detalles de la revisión sistemática y el proceso de extracción de datos.

Figura 17. Resumen del riesgo de sesgos para ensayos clínicos siguiendo la herramienta de Cochrane Collaboration.

Figura 18. Análisis agrupado principal de efectividad y eficacia de dos dosis de OCV. .86

Figura 19. Gráficos en embudo para evaluar el sesgo de publicación. .87

Figura 20. Eficacia y efectividad vacunal por tiempo de seguimiento (desde la vacunación) y número de dosis. .88

Figura 21. Eficacia con dos dosis por tiempo (en meses) desde la vacunación.......89

Figura 22. Eficacia por grupo de edad. .90

Figura 23. Relación entre la protección vacunal, tiempo de seguimiento y la 
media de edad de los pacientes con cólera.

Figura 24. Casos sospechosos de cólera por semana epidemiológica en el municipio de Bauleni ( área vacunada), áreas vacunadas (excluyendo Bauleni)

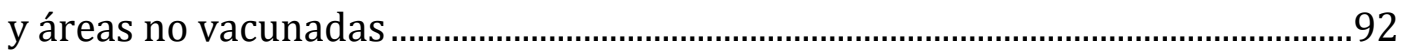

Figura 25. Distribución de la cobertura vacunal por edad y sexo .................................96

Figura 26. Diagrama de flujo del estudio ................................................................................97

Figura 27. Casos sospechosos en Lusaka en 2016 ........................................................ 102

Figura 28. Mapa de Lusaka por municipios .............................................................. 115

Figura 29. Pirámide poblacional de las personas participantes de la encuesta ...116

Figura 30. Cobertura vacunal con dos dosis por edad y sexo......................................119

Figura 31. Cobertura vacunal con al menos una dosis por edad y sexo....................119

Figura 32. Distribución geográfica de la CV en Kanyama, Chawama y George .....120 
SUMMARY 



\section{Introduction}

Cholera is an acute intestinal infectious disease that produces watery diarrhea with a massive loss of body fluids that can rapidly lead to severe dehydration and death in absence of adequate treatment (mortality over 50\%). Vibrio cholerae bacteria is the causal agent. The virulence of the pathogenic serogroups of Vibrio cholerae (01 and 0139) is associated with the cholera toxin, responsible for most of the clinical symptoms of the disease, especially the characteristic and profuse watery diarrhea. Current outbreaks are caused by 01 serogroup.

Cholera is transmitted through food and/or water supplies contaminated by the feces of infected people, or by drinking untreated water from sources that constitute the bacteria natural environmental reservoir. People living in places with lack of access to clean and safe drinking water and poor sanitation are particularly at risk of cholera.

Improving access to clean potable water and adequate sanitation remain the mainstay of cholera prevention and control. During ongoing epidemics, identification and appropriate treatment of people with cholera, implementation of clean water and sanitation facilities and promotion of hygiene practices should remain the principal control measures.

Since 2011, the World Health Organization (WHO) recommends the use of oral cholera vaccines (OCVs) during outbreaks and in cholera-endemic areas, as part of an integrated approach to cholera prevention and control. The immune response and protection against cholera is found in the intestinal mucosa. Three killed whole-cell oral cholera (OCV) vaccines are currently prequalified by WHO: Dukoral ${ }^{\circledR}$, Shanchol ${ }^{\mathrm{TM}}$ and Euvichol ${ }^{\circledR}$. In 2013, WHO created a global stockpile of OCVs to ensure vaccine availability for cholera control in outbreaks and humanitarian emergency situations, managed by the International Coordinating Group (ICG) and for use in endemic areas, managed by the OCV working group of the Global Task Force on Cholera Control (GTFCC). Supply of OCV remains low relative to the size of the global at-risk population. In addition, the recommended 
regimen for the WHO-prequalified vaccines is two doses given with an interval of 2 weeks. However, recent data suggest that a one-dose regimen (instead of two doses) could be sufficient to provide substantial protection in the short-term, which could highly increase the impact of reactive campaigns. A timely response is critical to reduce the magnitude and duration of cholera outbreaks. Public health decision-making regarding where, when and how to carry out reactive, timely and efficient vaccination campaigns is complicated since there are few data on vaccine efficacy and effectiveness and they vary according to the composition of the vaccine, the place where outbreak occurs, the study design and the duration of follow-up.

In April 2016, an emergency vaccination campaign using one dose of OCV was organized in response to a cholera outbreak that had started in Lusaka, Zambia in February 2016. In December 2016, a second round of vaccination was conducted, with the objective of increasing the duration of protection, before the high-risk season for cholera transmission which starts around January.

This work aims to gain evidence in the use of OCV in the fight against cholera through a systematic review and meta-analysis on OCV, an observational study in Lusaka to estimate the short-term effectiveness of one dose of OCV (Shanchol ${ }^{\mathrm{TM}}$ ) that was part of the integrated response to the 2016 cholera outbreak, and a study measuring vaccination coverage for the first and second rounds of the vaccination campaign.

\section{Objectives}

\subsection{Overall objective}

To assess the use of one dose of an oral vaccine dose in response to cholera epidemics in Lusaka followed by a second dose administration 8 months later to increase the duration of vaccine protection against cholera. 


\subsection{Specific objectives}

- To conduct a systematic review and meta-analysis to generate average estimates of OCV efficacy and direct effectiveness from the available literature. The outcomes are:

○ Vaccine efficacy and effectiveness:

- Overall

- By place

- By age group

- To estimate the short-term vaccine effectiveness of one-dose of oral cholera vaccine (Shanchol ${ }^{\mathrm{TM}}$ ) in individuals vaccinated during an emergency cholera vaccination campaign in Lusaka in 2016.

- To assess the vaccination coverage for the 2016 OCV campaign by:

○ Estimating the proportion of people vaccinated with two doses

- Estimating the percentage of people vaccinated with at least one dose

○ Estimating the percentage of people vaccinated with a single dose

- Estimating the proportion of people vaccinated during the first round

$\circ$ Estimating the proportion of people vaccinated during the second round

- Estimating the percentage of second dose drop-out

○ Evaluating the acceptability of the intervention as perceived by the population

○ Determining if the target population remained stable during the eight-month period between the two doses 


\section{Material and methods}

\subsection{Study oversight}

This work was funded by MSF (vaccine effectiveness study) and WHO (systematic review and meta-analysis, and coverage survey). Study design, data collection and data analysis was led by Epicentre. The study protocol was approved by the Ethical Review Boards of the University of Zambia and the Johns Hopkins Bloomberg School of Public Health (USA). Vaccine and treatment were provided free of charge. Vaccines were funded by the Global Alliance for Vaccines and Immunizations (Gavi). The participation in the study was voluntary and participants gave their signed informed consent before being included in the study.

\subsection{Systematic review and meta-analysis of killed whole-cell oral cholera vaccines}

For this systematic review and meta-analysis, we searched PubMed, Embase, Scopus, and the Cochrane Review Library on July 9, 2016, and ISI Web of Science on July 11, 2016, for randomised controlled trials and observational studies that reported estimates of direct protection against medically attended confirmed cholera conferred by OCVs. We included studies published on any date in English, Spanish, French, or Chinese. We extracted from the published articles the primary efficacy and effectiveness estimates from each study together with estimates of the number of vaccine doses, follow- up duration since vaccination, and age group. The main meta-analysis outcome was average efficacy and direct effectiveness of two OCV doses, which we estimated with random-effect models. This study is registered with PROSPERO, number CRD42016048232.

\subsection{One dose vaccine effectiveness study}

We conducted a matched case-control (MCC), test-negative case-control (TNCC), and case-cohort studies in 2016 in Lusaka immediately following the mass vaccination campaign. Confirmed (by culture and/or PCR) cholera cases served as cases in all three study designs. 


\subsubsection{Case-control analysis (MCC and TNCC)}

Age- and sex-matched controls were selected among neighbors of the confirmed cases in the MCC study. In the TNCC, control subjects were suspect cholera cases with negative cholera culture and PCR results. We compared the odds of vaccination between confirmed cholera cases and controls (non-cholera diarrhea or matched) using univariate and multivariable conditional logistic regression models. We calculated the vaccine effectiveness (VE) as (1-OR) x 100.

\subsubsection{Case-cohort analysis}

We recruited a cohort of randomly selected individuals living in areas targeted by the OCV campaign and considered at risk of cholera. We estimated unadjusted and adjusted hazard ratios (HR) of medically attended cholera comparing those who received one dose of vaccine to those who did not. The hazard ratio (HR) was then translated into overall VE through using the formula: $V E=(1-H R) \times 100$.

\subsubsection{Bias indicator analysis}

We also conducted an indicator bias analysis where the non-cholera diarrhea cases were compared with controls matched by age, sex and residence place in order to assess possible health seeking behavior bias. Because the vaccine was not expected to provide protection against non-cholera diarrhea, in the absence of bias, we expected a null association between vaccination and non-cholera diarrhea

\subsection{OCV campaign coverage}

Vaccination coverage was estimated after each round of the campaign from a sample randomly selected from areas targeted for vaccination using a crosssectional survey design to establish the vaccination status of the individuals recruited. The study population included all individuals older than 12 months residing in the areas targeted for vaccination. Households were selected using spatial random sampling. One individual was randomly selected in each household among all eligible individuals being part of the household at the time of the survey. Vaccination status was ascertained either by vaccination card or verbal reporting. 


\section{Results}

Seven trials (accounting for 695 patients with cholera) and six observational studies (217 patients with cholera) met the inclusion criteria for the systematic review, with an average two-dose efficacy of 58\% (95\% confidence interval (CI): $\left.42-69, I^{2}=58 \%\right)$ and effectiveness of 76\% (95\% CI: $\left.62-85, I^{2}=0\right)$. Two-dose efficacy estimates of OCV were similar during the first 2 years after vaccination, with estimates of 56\% (95\% CI: 42-66, $I^{2}=45 \%$ ) in the first year and 59\% (95\% CI: 49$67, I^{2}=0$ ) in the second year. The efficacy decreased to $39 \%$ (95\% CI: $13-57$, $I^{2}=48 \%$ ) in the third year, and 26\% (95\% CI: $\left.-46-63, I^{2}=74 \%\right)$ in the fourth year. Average two-dose efficacy in children younger than 5 years (30\% [95\% CI: 15-42], $\left.I^{2}=0 \%\right)$ was lower than in those 5 years or older (64\% [95\% CI: 58-70], $I^{2}=0 \%$; $\mathrm{p}<0 \cdot 0001)$.

The first case of the 2016 February outbreak was reported on $4^{\text {th }}$ February 2016 (week 5). A sharp increase of suspected cases occurred at week 10. The highest (overall) number of cases was observed during week 12, with 150 suspected cholera cases. The one-dose OCV vaccination campaign started at week 14 and finished at week 16. Overall, 424.100 doses were administered resulting in an estimated administrative coverage of $73.4 \%$. The last confirmed case was reported on 30 ${ }^{\text {th }}$ May 2016 (week 22). The outbreak was officially declared over on June 15th, 2016 (week 24).

We recruited 211 suspected cases (66 confirmed cholera cases and 145 noncholera diarrhea cases), 1055 matched controls and a cohort of 921 people. Adjusted vaccine effectiveness for one dose of OCV was 88.9\% (95\% CI: 42.797.8\%) in the MCC study, 80.2\% (95\% CI: 16.9-95.3\%) in the TNCC design and 89.4\% (95\% CI: 64.6-96.9\%) in the case-cohort study. The bias-indicator analysis included 145 persons with non-cholera diarrhea and 725 matched controls. In that analysis, the odds of vaccination did not vary significantly between the two groups in the crude or adjusted analyses ( $\mathrm{p}=0.29$ in the adjusted analysis) suggesting the absence of selection bias. 
We interviewed 505 randomly selected individuals after the first round and 442 after the second round. The vaccination coverage with two doses was $58.1 \%$ (25/43; 95\%CI: 42.1-72.9) in children 1-4 years old, 59.5\% (69/116; 95\%CI: 49.9-68.5) in children 5-15 years old and 19.9\% (56/281; 95\%CI: 15.4-25.1) in adults above 15 years old. The overall dropout rate was 10.9\% (95\%CI: 8.1-14.1). Overall, 69.9\% ( $n=309 / 442 ; 95 \% C I$ : 65.4-74.1) reported to have received at least one OCV dose.

\section{Conclusions}

- The past three decades of evidence points towards OCV being a safe, effective, and important tool to fight cholera. Two OCV doses provide protection against cholera for at least three years. One OCV dose provides at least short-term protection, which has important implications for outbreak management. OCVs are effective tools for cholera control.

- Three study designs confirmed the short-term effectiveness of a single dose of OCV. Major healthcare-seeking behavior bias did not appear to affect our estimates. Most of the protection among vaccinated individuals could be attributed to the direct effect of the vaccine. Our results indicate that the use of single dose regimens provides high short-term protection in areas with little to no recent exposure to cholera and support recommendations for the use of one-dose regimen to improve and accelerate the response in cholera outbreaks.

- The areas at highest risk of suffering of cholera were targeted for vaccination and reached relatively high vaccine coverage after each round. However, the long delay between doses in those areas known to have considerable population movements, resulted in many individuals receiving only one OCV dose. 
The results of this systematic review and meta-analysis served as evidence for the background document prepared by the Strategic Advisory Group of Experts (SAGE) Working Group on Oral Cholera Vaccines, the WHO Secretariat, and the CDC in March 31, 2017. This document, reviewed the previous oral cholera vaccine WHO position paper (2010) with updated information on OCV, described and proposed recommendations about safety, efficacy, effectiveness and duration of OCVs protection during the 5 years following immunization.

The short-term OCV effectiveness study in Lusaka served as evidence to generate recommendations on the use of vaccines for cholera control in epidemics in the WHO cholera position paper of August 2017. ("Based on available evidence on short-term protection conferred by WC vaccines, a single-dose strategy using those vaccines could be considered in areas experiencing cholera outbreaks.") 
RESUMEN 



\section{Introducción y justificación}

El cólera es una infección intestinal aguda que produce una diarrea acuosa con una pérdida masiva de fluidos y que puede evolucionar a una deshidratación severa y muerte en ausencia de tratamiento, alcanzando una letalidad mayor del 50\%. El agente causal es la bacteria Vibrio cholerae. La virulencia en las variedades patogénicas del Vibrio cholerae (01 y 0139) está asociada a la toxina colérica, responsable de la mayoría de los síntomas clínicos de la enfermedad, en especial de la peculiar diarrea acuosa y profusa. El serotipo 01 es el causante de las pandemias registradas hasta ahora.

La transmisión se produce a través de la ingesta de agua no tratada procedente de fuentes que actúan como reservorio ambiental natural de la bacteria, o de comida y/o suministros de agua contaminados por heces de personas infectadas. Las personas que viven en lugares con suministros de agua contaminados y un nivel deficiente de saneamiento, se encuentran particularmente en riesgo de cólera

La prevención y control del cólera está estrechamente relaccionado con el acceso al agua potable e infraestructuras de saneamiento. Durante una epidemia, la respuesta está enfocada en la identificación y tratamiento temprano de los casos, la provisión de agua potable, de medidas hacia una gestión adecuada del saneamiento y en la promoción de buenos hábitos de higiene.

Desde 2011 la Organización Mundial de la Salud (OMS) recomienda la vacunación dentro del arsenal de respuesta frente a epidemias. La respuesta y protección inmunológica frente al cólera se encuentra en la mucosa intestinal. Las vacunas orales frente al cólera (OCV) precalificadas por la OMS son: Dukoral ${ }^{\circledR}$, Shanchol ${ }^{\mathrm{TM}} \mathrm{y}$ Euvichol ${ }^{\circledR}$. En 2013, la OMS estableció una reserva global de OCV para garantizar su disponibilidad para el control del cólera en caso de brote o crisis humanitaria financiada por GAVI y gestionada por el Grupo Coordinador Internacional (ICG) (en los casos epidémicos) y el Grupo de Trabajo Global para el Control del Cólera (GTFCC) (en los casos endémicos), ya que dicha reserva es limitada frente a las necesidades epidémicas y endémicas de cólera mundiales existentes. Además. las 
vacunas precalificadas por la OMS establecen un régimen de dos dosis con un intervalo de 2 semanas. La toma de decisiones de salud pública sobre dónde, cuándo y cómo realizar las campañas de vacunación reactivas, oportunas y eficientes es complicada ya que existen pocos datos de eficacia y efectividad vacunal que varían a su vez según la composición de la vacuna, el lugar donde se produce el brote, el diseño del estudio y la duración del seguimiento.

La respuesta temprana y oportuna es factor clave para reducir la magnitud y duración de los brotes de cólera. Datos recientes sugieren que el uso de una dosis (en lugar de dos) podría proporcionar una protección considerable a corto plazo, pudiendo incrementar en gran medida el impacto de las campañas reactivas de vacunación.

En abril de 2016, se organizó una campaña de vacunación de emergencia con una dosis de OCV dentro de las medidas de respuesta al brote de cólera que comenzó en Lusaka (Zambia) en febrero de 2016. En diciembre de 2016, se realizó una segunda ronda de vacunación, con el objetivo de incrementar la duración de la protección, antes del período de alto riesgo para la transmisión del cólera.

El trabajo que presentamos a continuación pretende contribuir a la generación de evidencia científica hacia la lucha frente al cólera mediante una revisión sistemática y metaanálisis de las $\mathrm{OCV}$, un estudio que pretende estimar la efectividad vacunal a corto plazo de una dosis de OCV (Shanchol ${ }^{\mathrm{TM}}$ ) usada en Zambia en el contexto citado y una evaluación de la cobertura vacunal de la primera y segunda ronda de la campaña de vacunación en dicho país.

\section{Objetivos}

\subsection{Objetivo general}

Evaluar el uso de una dosis de vacuna oral inactivada en respuesta a la epidemia de cólera de 2016 en Zambia y la administración de la segunda dosis (8 meses después) para incrementar la duración de la protección de la vacuna. 
Este objetivo global se aborda mediante los siguientes objetivos específicos.

\subsection{Objetivos específicos}

- Llevar a cabo una revisión sistemática y metanálisis de la literatura disponible para generar estimaciones promedio de eficacia y efectividad directa de la vacuna inactivada oral frente al cólera.

- Estimación de eficacia y efectividad vacunal global.

○ Estimaciones en función del lugar.

○ Estimaciones en función del grupo de edad.

- Estimar la efectividad a corto plazo de una dosis de vacuna oral frente al cólera como medida de respuesta frente al brote de Lusaka, Zambia, en 2016.

- Determinar la protección a corto plazo de una dosis de vacuna oral frente al cólera Shanchol ${ }^{\mathrm{TM}}$.

- Evaluar la cobertura vacunal de la campaña de vacunación en Lusaka, Zambia en 2016 con dos dosis en una pauta de intervalo de 8 meses.

- Estimar la proporción de personas vacunadas con dos dosis.

- Estimar el porcentaje de personas vacunadas con al menos una dosis.

- Estimar la proporción de personas vacunadas con una dosis.

- Estimar la proporción de personas vacunadas durante la primera ronda.

- Estimar la proporción de personas vacunadas durante la segunda ronda.

- Calcular la tasa de abandono en la segunda dosis.

- Evaluar la aceptabilidad de la intervención percibida por la población.

- Entender si la población diana continúa estable en los ocho meses entre ambas rondas de vacunación. 


\section{Materiales y métodos}

\subsection{Marco y diseño general del proyecto de investigación}

Este proyecto fue financiado por MSF (el estudio de efectividad vacunal) y la OMS (la revisión sistemática y meta-análisis y la encuesta de cobertura vacunal). El diseño, recogida de datos y análisis fue liderado por Epicentre. El protocolo del estudio fue aprobado por los comités de ética de la Universidad de Lusaka (Zambia) y la Escuela de Salud Pública de la Universidad Johns Hopkins (USA). La distribución de la vacuna y tratamiento contra el cólera fue gratuito. La participación en el estudio fue voluntaria.

\subsection{Revisión sistemática y meta-análisis de vacunas inactivadas orales frente al cólera}

Se realizaron búsquedas de ensayos controlados aleatorios y estudios observacionales que reportaban estimaciones de protección directa por vacunas orales frente al cólera confirmado y atendido médicamente a través de PubMed, Embase, Scopus y la Cochrane Review Library el 9 de julio de 2016, y el ISI Web of Science el 11 de julio de 2016. Se incluyeron estudios publicados en cualquier fecha en inglés, español, francés o chino. Se estudiaron las estimaciones primarias de eficacia y efectividad de cada estudio publicado y las estimaciones por número de dosis de vacuna, duración del seguimiento y grupo de edad. Para estudiar la eficacia promedio y la efectividad directa de dos dosis de OCV utilizamos modelos de efectos aleatorios. Este estudio está registrado en PROSPERO, número CRD42016048232.

\subsection{Estudio de eficacia vacunal de una dosis}

Se plantearon tres estudios para estudiar la eficacia vacunal de una dosis vacuna tras la campaña masiva de vacunación en Lusaka, Zambia en mayo de 2016: un estudio de casos y controles pareado (MCC), un test- negative de casos y controles (TNCC), y un caso-cohorte (CC) .. Los casos confirmados (por cultivo y/o PCR) servían como casos para los tres diseños. 


\subsubsection{Análisis de casos y controles (MCC y TNCC)}

En el estudio de MCC, los controles se eligieron de forma aleatoria entre los vecinos de la misma edad y sexo que su caso confirmado. En el de TNCC, los sujetos-control eran casos sospechosos con diarrhea no colérica (negativos a cultivo y PCR). Se compararon las probabilidades de vacunación entre los casos confirmados y los sujetos control (pareados o con diarrea no colérica según el diseño) por medio de modelos de regresión logística condicional univariable y multivariable. Se calculó el nivel de protección de la vacuna como: $\mathrm{EV}=(1-\mathrm{OR})$ x 100.

\subsubsection{Análisis de caso-cohorte}

Se reclutó una cohorte de individuos seleccionados al azar procedentes de áreas consideradas de alto riesgo de transmisión de cólera. Se estimó el cociente de riesgo (HR) de cólera (atendido médicamente) comparando aquellos que recibieron la vacuna con los que no la recibieron. La EV se calculó mediante la fórmula: $E V=(1-H R) \times 100$.

\subsubsection{Análisis de indicador de sesgo}

Se realizó un análisis de indicador de sesgo anidado, donde los casos de diarrea no colérica eran comparados con controles emparejados por edad, sexo y residencia, para detectar posibles sesgos relacionados con diferencias en la búsqueda de atención sanitaria, si estuvieran presentes. En el análisis de indicador de sesgo se esperaba una asociación nula entre la vacuna y la diarrea no colérica.

\subsection{Encuesta de cobertura de la campaña de vacunación.}

Se estimó la cobertura vacunal después de cada ronda mediante una muestra procedente de las áreas seleccionadas para la campaña de vacunación usando una encuesta transversal. El estado vacunal se determinó mediante la presentación del carné de vacunación o autorreportado. Los hogares fueron seleccionaron por muestreo espacial aleatorio.

\section{Resultados}

7 ensayos clínicos (695 pacientes con cólera) y 6 estudios observacionales (217 pacientes con cólera) cumplían los criterios de inclusión, con una eficacia media de 
dos dosis del 58\% (IC 95\% 42-69, $I^{2}=58 \%$ ) y una efectividad del 76\% (62-85, $I^{2}=0$ ). La eficacia media de dos dosis en menores de 5 años (30\% [IC 95\% 15-42], $I^{2}=0 \%$ ) fue más baja que para aquellos a partir de 5 años de edad (64\% [58-70], $I^{2}=0 \% ; \mathrm{p}<0 \cdot 0001$ ). La eficacia de dos dosis de OCV fue similar durante los dos primeros años posteriores a la vacunación, con estimaciones del 56\% (IC 95\% 42$\left.66, I^{2}=45 \%\right)$ en el primer año y del 59\% (49-67, $\left.I^{2}=0\right)$ en el segundo año. La eficacia disminuye al 39\% (13 to $57, I^{2}=48 \%$ ) durante el tercer año, y al 26\% (-46 to $63, I^{2}=74 \%$ ) durante el cuarto año.

El primer caso de cólera en Lusaka (Zambia) fue notificado el 4 de febrero de 2016 (semana epidemiológica 5). En la semana epidemiológica 10 se produjo un fuerte incremento de casos sospechosos. El mayor número de casos notificados se observó durante la semana epidemiológica 12, con un total de 150 casos sospechosos. La campaña de vacunación con una dosis de OCV empezó en la semana epidemiológica 14 y terminó en la semana 16. En total se adminisitraron 424.100 dosis resultando una cobertura administrativa del 73,4\%. El último caso confirmado fue notificado el 30 de mayo de 2016 (semana epidemiológica 22). La declaración oficial del final del brote fue el 15 de junio de 2016 (semana epidemiológica 24).

Se reclutaron 211 casos sospechosos (66 casos confirmados de cólera y 145 casos de diarrea no colérica), 1055 controles pareados y una cohorte de 921 personas. La efectividad vacunal de una dosis de OCV fue del 88.9\% (IC 95\%: 42.7-97.8\%) en el estudio de MCC, 80.2\% (IC 95\%: 16.9-95.3\%) en el estudio de TNCC y del 89.4\% (IC 95\%: 64.6-96.9\%) en el estudio de caso-cohorte. Incluimos 145 personas con diarrea no colérica en el análisis de indicador de sesgo y 725 controles pareados. En dicho análisis encontramos que la probabilidad de vacunación no variaba significativamente en los dos grupos tanto en el análisis crudo como ajustado $(\mathrm{P}=$ 0.29), sugiriendo una ausencia de sesgo de selección.

La cobertura vacunal con dos dosis fue del 58.1\% (25/43; IC 95\%: 42.1-72.9) en los menores entre 1 y 5 años de edad, 59.5\% (69/116; IC 95\%: 49.9-68.5) en menores entre 5 y 15 años de edad y del 19.9\% (56/281; IC 95\%: 15.4-25.1) en 
personas adultas mayores de 15 años. El porcentaje de abandono global fue del 10.9\% (IC 95\%: 8.1-14.1). Globlamente, el 69.9\% (n = 309/442; IC95\%CI: 65.474.1) reportó haber recibido al menos una dosis de OCV.

\section{Conclusiones}

- Las últimas tres décadas de evidencia científica apuntan a que las vacunas orales frente al cólera son una herramienta segura, efectiva e importante para combatir la infección por cólera. Dos dosis de vacuna oral frente al cólera proporcionan una protección de al menos 3 años. Una dosis de vacuna oral frente al cólera proporciona al menos una protección a corto plazo, lo que tiene implicaciones importantes para el manejo de brotes.

- Los tres diseños del estudio observacional en Lusaka confirmaron la efectividad a corto plazo de una dosis de OCV administrada durante un brote. Las estimaciones obtenidas no parecen estar afectadas por el sesgo de comportamiento de búsqueda de atención médica. La mayor parte de la protección entre las personas vacunadas podría atribuirse al efecto directo de la vacuna. Los resultados indican que la pauta vacunal de una dosis brinda protección en poblaciones con poca o nula exposición al cólera y respaldan el uso de pautas de una dosis para mejorar la respuesta durante un brote de cólera.

- La campaña de vacunación se realizó en las áreas con mayor riesgo de padecer brotes de cólera, obteniendo una cobertura vacunal relativamente alta después de cada ronda. Sin embargo, la larga demora entre las dos rondas en áreas sujetas a un considerable movimiento de población resultó en que, al final de la campaña, muchas personas recibieran una sola dosis de OCV.

Los resultados de la revisión y meta-análisis presentados en este trabajo sirvió como evidencia científica durante la preparación del documento de actualización elaborado por el Grupo de trabajo de Asesores Estratégicos de Expertos en 
vacunas frente al cólera (SAGE), la OMS y el CDC el 31 de marzo de 2017, en el que revisaban el anterior documento de posición de la OMS sobre las vacunas orales frente al cólera de 2010, para describir y elaborar recomendaciones sobre la seguridad, eficacia, efectividad y duración de la protección de las OCV durante los 5 años seguidos a la inmunización.

El estudio de eficacia vacunal de una dosis a corto plazo sirvió de evidencia científica para generar recomendaciones sobre el uso de vacunas para el control del cólera en epidemias recogidas en el documento de posición de la OMS sobre las vacunas orales frente al cólera de agosto de 2017; en la recomendación de considerar la estrategia de una dosis en brotes de cólera. 
INTRODUCCIÓN 



\section{INTRODUCCIÓN}

\subsection{Origen, aspectos generales y carga de la enfermedad.}

El cólera es una infección intestinal aguda que produce una diarrea acuosa y profusa muy característica, con una pérdida masiva de fluidos y que puede evolucionar a una deshidratación severa y muerte en un plazo de 12 a 24 horas, desde el inicio de síntomas y en ausencia de tratamiento, alcanzando una letalidad (TL) mayor del 50\%. La mayoría de las infecciones son asintomáticas o vienen acompañadas de una diarrea leve. Aun así, puede causar brotes explosivos y fallecimiento por shock hipovolémico antes de la llegada al centro sanitario. La muerte por cólera es fácilmente evitable mediante rehidratación oral, y/o intravenosa en los casos graves, disminuyendo la TL a menos del 1\%. (1)
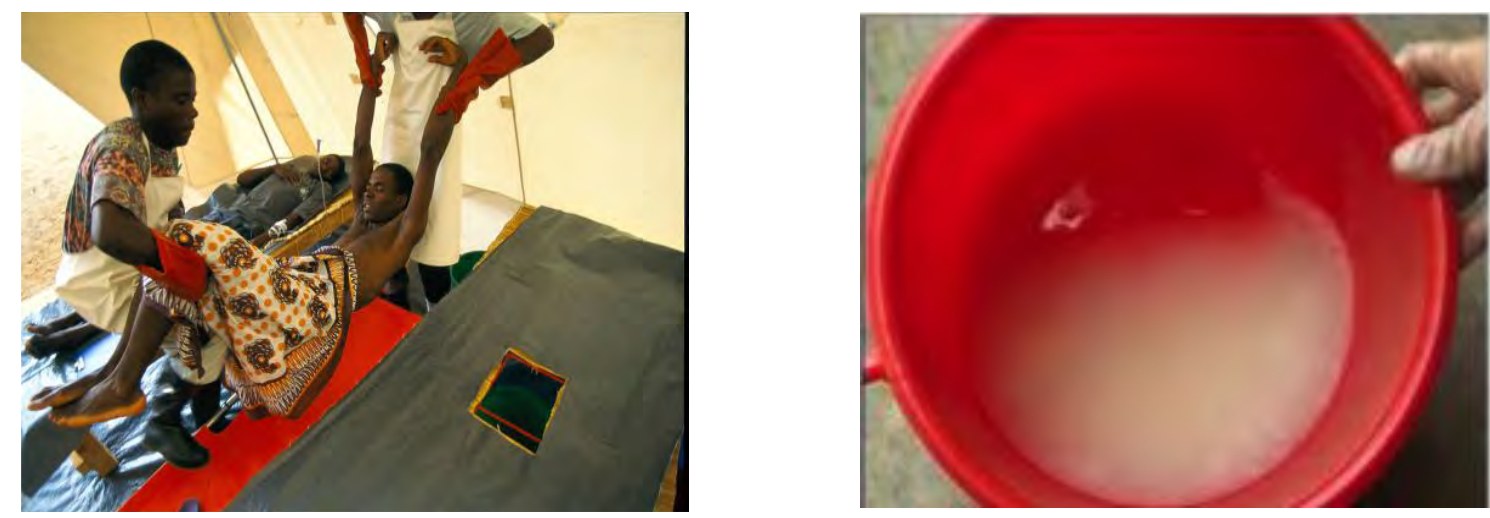

Figura 1. Presentación clínica y deposiciones coléricas

Esta enfermedad es muy antigua. Las primeras descripciones datan del siglo $\mathrm{V}$ antes de Cristo procedentes del delta del Ganges (en el golfo de Bengala) en la India, donde ha persistido durante siglos. En 1817 el cólera se propagó a través del subcontinente indio. En 1854 John Snow describió la epidemiologia del cólera como una enfermedad transmisible, sugiriendo que el agente infeccioso se podría encontrar en las heces y que la transmisión podría producirse a través de sistemas de abastecimiento de agua contaminada. (2). En 1854 Flippo Pancini observó el bacilo con forma de coma por primera vez al microscopio y Robert Koch lo aisló en 1884. 
La transmisión se produce a través de la ingesta de agua no tratada procedente de fuentes que actúan como reservorio ambiental natural del organismo, o de comida y/o suministros de agua contaminados por heces de personas infectadas. En contextos endémicos, el cólera suele afectar a la misma población y la fuente de infección se encuentra a menudo en ecosistemas marinos, donde la bacteria puede persistir en estado libre o en asociación con el fitoplancton, zooplancton o factores bióticos y abióticos (por ejemplo, usando la quitina de los copépodos como fuente de carbono y nitrógeno). No obstante, la trasmisión persona-persona, via contaminación fecal, tiene un rol esencial en la epidemiología de la enfermedad tanto en contextos endémicos como epidémicos. Personas que viven en lugares con suministros de agua contaminados y un nivel deficiente de saneamiento, se encuentran particularmente en riesgo de cólera; en especial en condiciones de hacinamiento, como en el caso de los campos de refugiados saturados, siendo el riesgo de epidemia muy alto ya que la bacteria permanece altamente infecciosa durante al menos 5 horas después del paso del hospedador humano al medio acuático $(3,4)$. Otros factores de riesgo a nivel individual son la hipoclorhidria gástrica, la ausencia de lactancia materna (en niños) y pertenecer al grupo sanguíneo 0 (5-7). 


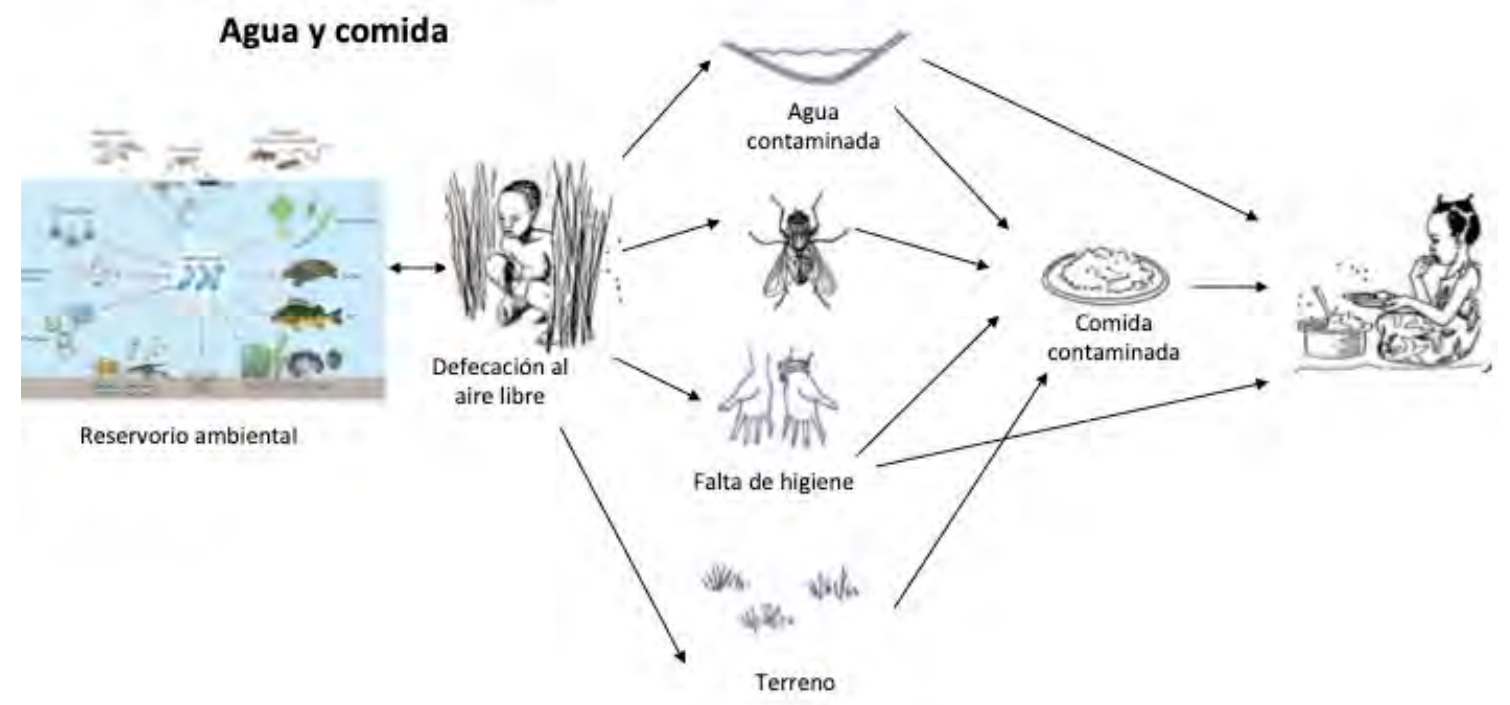

Figura 2. Mecanismos de transmisión seguidos por VC

Durante el último siglo el cólera se ha ido eliminado de los países industrializados gracias al conocimiento y las mejoras en la infraestructura dirigida al acceso de agua potable y al tratamiento de aguas residuales. En España el último brote epidémico fue en 1979. Los primeros casos aparecieron en Melilla en julio de 1979 y de ahí pasó a la península siguiendo la ruta habitual de emigración europea a través de Málaga y Barcelona. El brote finaliza el 24 de octubre con un total de 264 casos (8). Sin embargo, hoy en día sigue siendo una causa importante de morbilidad y mortalidad en los países de mediano y bajo ingreso, donde es un indicador de infraestructura en agua potable y saneamiento inadecuados. Según un análisis de 2015, la carga global anual de cólera se estimó en aproximadamente 2,86 millones de casos y 91.000 defunciones por año. El cólera es endémico en más de 50 países y la mayoría de los casos notificados proceden del África subsahariana (9). Aproximadamente la mitad de la carga de mortalidad se debe a menores de 5 años. 


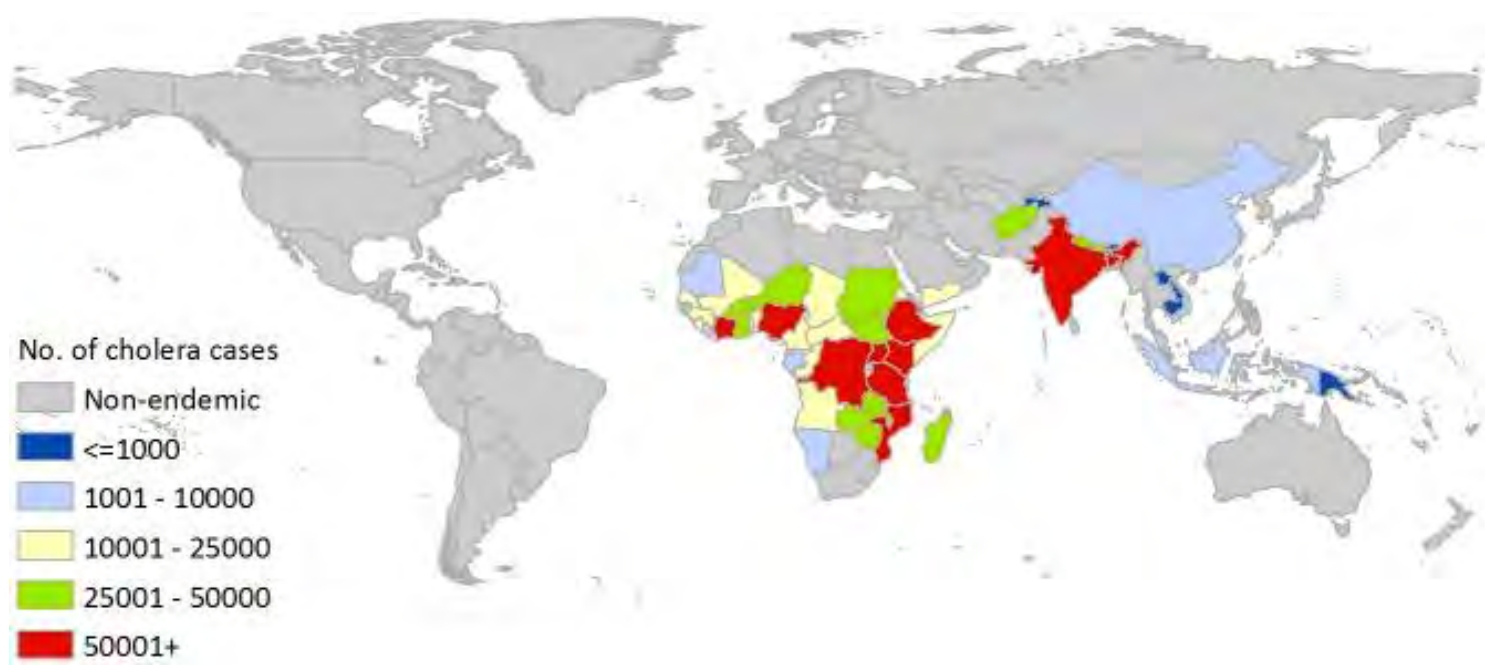

Figura 3. Casos anuales de cólera en países endémicos. Tomado de (9)

El Vibrio cholerae es una bacteria gram-negativa y se clasifica en serogrupos de acuerdo con la estructura del antígeno-0 de la membrana. En el medio ambiente existen más de 200 serogrupos, pero sólo el 01 y el 0139 tienen relevancia clínica (por secretar toxina colérica) y, de éstos, únicamente el Vibrio cholerae 01 es el agente causal de las pandemias registradas hasta el momento. El resto de serogrupos, llamados no-01/no-0139, se encuentran de forma natural en ecosistemas acuáticos (particularmente en aguas salinas costeras y estuarios y a menudo en asociación con el zooplancton y mariscos) y son raramente toxigénicos $(<1 \%)$; pero podrian constituir un reservorio potencial de cepas que podrían adquirir genes de virulencia (toxina colérica) y, por tanto, contribuir a la evolución de las cepas patogénicas (10).

Tabla 1. Diversidad del $V C$ en el medio ambiente

\begin{tabular}{l|c|c}
\multicolumn{1}{c|}{ Serogrupo } & Cápsula & Toxigenicidad \\
\hline $01($ Tox +$)$ & - & + \\
$01($ Tox-) & - & - \\
$02-0138$ & $+0-$ & - \\
$0139($ Tox +$)$ & + & + \\
$0140-0200$ & $+0-$ & -
\end{tabular}

Entre 1817 y 1923 se han registrado 6 pandemias (con fechas de inicio: 1817, $1829,1852,1863,1881$ y 1889) afectando a todos los continentes. Actualmente 
nos encontramos en la séptima pandemia que comienzó en 1961 en Indonesia y llegó a África en 1970. La plausibilidad de la transmisión de la bacteria entre países y dentro del mismo en los diferentes periodos de tiempo viene dada por las diferencias genéticas entre cepas. El biotipo Clásico parece ser el responsable de las primeras 6 pandemias. Sin embargo, en la actual ha sido desplazado por el biotipo El Tor. Entre 1970 y 2007 ha habido al menos 12 introducciones al continente Africano. Podemos distinguir principalmente dos serotipos tanto entre las cepas clásicas como entre las cepas El Tor; el serotipo Ogawa y el Inaba. Un tercer serotipo, el Hikojima, se encuentra raramente de manera estable.

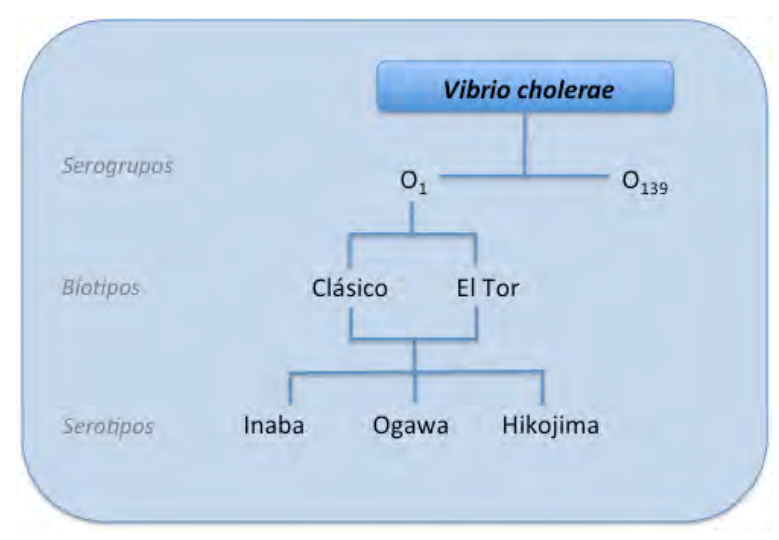

Figura 4. Clasificación del Vibrio cholerae

A raíz de los brotes en India y Bangladesh producidos en 1992 y causados por el serogrupo $0139(11,12)$, se abrió la sospecha de que este serogrupo pueda ser el causante potencial de una nueva pandemia. (13).

La prevención y control del cólera están estrechamente relaccionados con el acceso al agua potable e infraestructuras de saneamiento. Durante una epidemia, el foco de la respuesta está en la identificación y tratamiento temprano de los casos, la provisión de agua potable, de medidas hacia un adecuado saneamiento y en la promoción de buenos hábitos de higiene. Desde 2011 la OMS recomienda la vacunación dentro de las medidas de respuesta (14).

La persistencia o el control del cólera en África va a ser un indicador clave de los esfuerzos mundiales para alcanzar los Objetivos de Desarrollo Sostenible apoyados por el PNUD (Programa de las Naciones Unidas para el Desarrollo) (15). 


\subsection{Genética del Vibrio cholerae}

La virulencia en las variedades patogénicas del Vibrio cholerae (01 y 0139) está asociada a un bacteriofago filamentoso (CTX), procedente de una familia de virus que participan en la conversión lisogénica de bacterias gram-negativas patógenas y que contiene los genes que codifican la toxina colérica (CT), responsable de la mayoría de los síntomas clínicos de la enfermedad, en especial de la peculiar diarrea acuosa y profusa. Existen al menos 200 especies de bacteriófagos que infectan al VC, conocidos como vibriofagos. La expresión de las partículas del fago es específica al biotipo (16).

El anclaje e integración del CTX al cromosoma bacteriano del VC se realiza a través del pili corregulado con la toxina (TCP) que, además de actuar como receptor, es un factor para la colonización del tracto intestinal, siendo éste el hábitat natural de ambos, fago y bacteria. El TCP está codificado por un elemento genético móvil llamado isla de patogenicidad de Vibrio (VPI), "Vibrio seventh pandemic (VSP) islands" en las cepas de la $7^{a}$ pandemia (17).

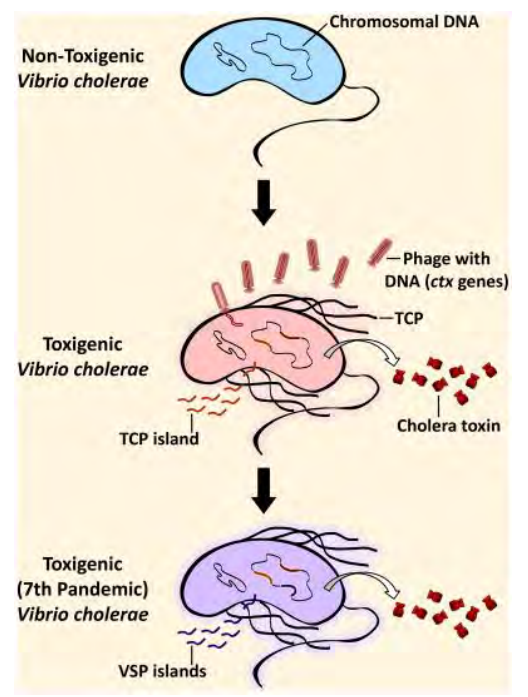

Figura 5. Mecanismo e toxigenicidad del VC. Tomado de (18)

Durante la infección, el Vibrio cholerae expresa CT y TPC. Existe una co-evolución de los elementos genéticos que median la transferencia de genes de virulencia con las especies de bacterias patogénicas que infectan, pudiendo emerger cepas toxigénicas nuevas a través de este mecanismo (19). El genoma del Vibrio cholerae consta de dos cromosomas: uno largo y otro corto. Normalmente el CTX se inserta 
en un sitio especifico (llamado att) cerca del terminal de replicación del cromosoma largo, aunque se han documentado integraciones alternativas en el cromosoma pequeño (20).

Desde el punto de vista funcional, el CTX que contiene las cepas de VC consiste en dos grupos de genes distintos: el núcleo y la región RS2. El núcleo incluye los genes ctxAB, que codifican la CT; y otros 5 genes, Psh, Cep, pIIICTX/orfU, Ace y Zot, necesarios para la morfogénesis del fago y la actividad enterotóxica (Ace y Zot) $(21,22)$. El ctxA es idéntico en los dos fagos Clásico y El Tor, mientras que el ctxB difiere en dos aminoácidos en los residuos 39/18 y 68/47 (19,21). La región RS2 codifica las proteínas necesarias para la replicación (RstA), integración (RstB) y regulación (RstR) de la recombinación del CTX en el cromosoma del VC. Variaciones en la secuencia del RstR clasifican variaciones del CTX y por tanto de las cepas de VC (El biotipo Clásico contiene el profago CTXcla y el biotipo El Tor el CTXEI Tor o CTX-1). Las cepas de El Tor contienen además un satélite conocido como RS1, que es similar al RS2 con un gen más (el rstC), que codifica una proteína antirepresora que promueve la transcripción de genes necesarios para generar partículas infecciosas $(19,23)$. El sistema de recombinación que cataliza la integración de los plásmidos del CTX en los cromosomas de las cepas Vibrio cholerae no toxigénicas, a través del att del RS1, viene codificado por las secuencias RS (rstABCR) (17)

(a) EI Tor

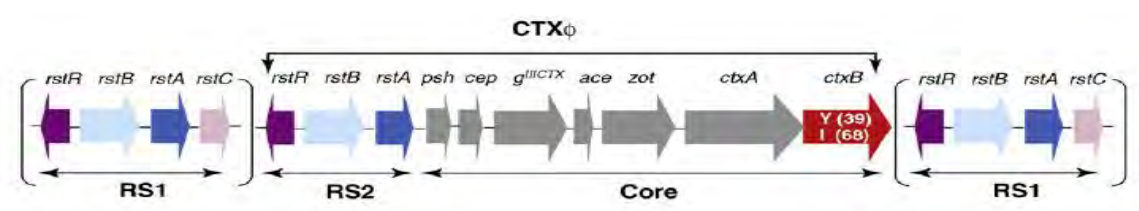

(b) Classical
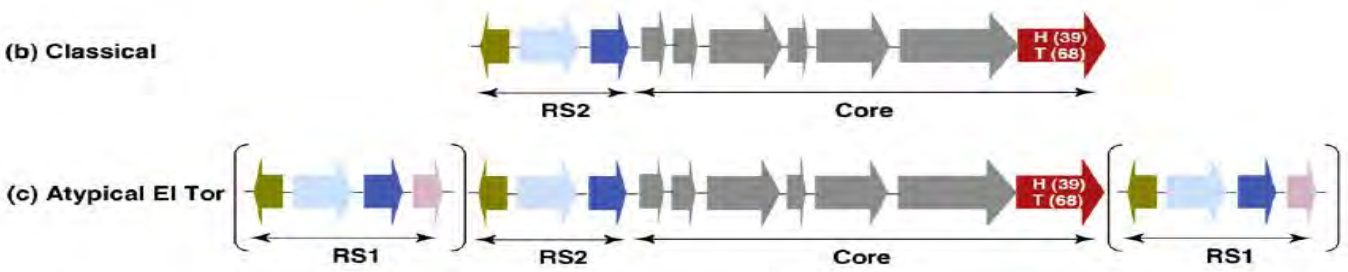

(d) Hybrid

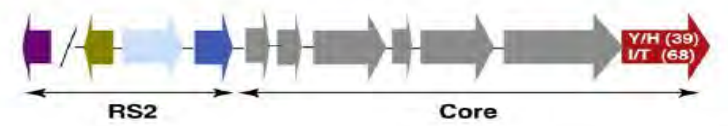

TAENDS in Microbiology

Figura 6. Estructura del CTX y el RS1 en diferentes variantes del VC 01. Tomado de (22) 
Desde el punto de vista filogenético, la actual séptima pandemia se puede dividir en tres grupos en función de las características de la CT, representando 3 olas independientes de transmisión (24). Las dos cepas más frecuentes en los últimos 100 años pertenecen a los biotipos Clásico y El Tor. Esta clasificación se basa, no solo en diferencias fenotípicas (capacidad de hemolizar eritrocitos ovinos, aglutinar eritrocitos de aves, producir la reacción de Voges-Proskauer, susceptibilidad a la polimixina B y la posesión de fagos específicos al biotipo (19)) y genotípicas, sino que además determina unas diferencias en la patogenia y en los patrones de transmisión y supervivencia. Esto hace que las cepas de El Tor estén más asociadas a infecciones asintomáticas y de mayor supervivencia tanto en el ambiente como en el hospedador humano (y siendo por tanto más eficientes en la transmisión) que las cepas del Clásico que manifiestan una clínica más severa $(22,25)$.

Además de los biotipos el Clásico y El Tor, una nueva variante, el llamado biotipo El Tor atípico, se ha desarrollado a partir de 1991 (17,22). Esta cepa ha evolucionado desde la variante El Tor con adquisición de algunos de los atributos del genoma del Clásico (alelos rstRcla y ctxB1), mediante recombinación genética de ambos. Esta variante El Tor atípico, que produce la CT del Clásico, ha desplazado el biotipo El Tor en Bangladesh a partir de 2001 (26) y se ha propagado a otros países en Asia ( India, Vietnam,...) y África (la primera cepa fue en Mozambique durante la epidemia de $2004(27,28)$ ) mostrando una gran diversidad genética e indicando que su difusión es resultado de la expansión multiclonal en lugar de un clon único. Las cepas El Tor se clasifican en 2 grupos, ola 2 y ola 3, en función de las variaciones genómicas y el CTX que albergan: CTX-1 (ola 1) y CTX-2 (ola 2) $(24,29)$. Las cepas causantes de la epidemia de cólera en Haiti muestran una relación con las cepas aisladas en Bangladesh entre 2002 y 2008, que se diseminaron a Nepal antes de alcanzar Haiti en 2010 (30).

Entre 1991 y 2004 se aislaron cepas de El Tor, en varios países Asiáticos y Africanos, que pueden albergar tanto el alelo ctxB de El Tor como el del Clásico. Asi mismo, muchas de estas cepas llevan tanto el rstRcla como el rstRel. Estas variedades se han denominado híbridas y contienen tanto el gen para la toxina 
colérica B (ctxB) del tipo El Tor y/o del Clásico a diferencia de las cepas alteradas que solo contienen el del Clásico (31).

Tabla 2. Características fenotípicas y genotípicas de cepas VC 01

\begin{tabular}{|c|c|c|c|c|c|c|c|c|c|}
\hline \multirow[t]{2}{*}{ Blotype or variant } & & \multicolumn{5}{|c|}{ Phenotypes ${ }^{b}$} & \multicolumn{3}{|c|}{ Genotypes } \\
\hline & & CCA & PB & VP & Phage IV & Phage 5 & $\operatorname{tcp} A$ & $r s t R$ & $\operatorname{ct} \times B$ \\
\hline \multirow[t]{2}{*}{ Trpical biotypes } & Classical & - & $s$ & - & 5 & $r$ & $\mathrm{Cla}_{\mathrm{a}}$ & $\mathrm{Cla}_{\mathrm{a}}$ & B1 \\
\hline & El Tor & + & $r$ & + & $r$ & 5 & El & $\mathrm{El}$ & B3 \\
\hline \multirow[t]{6}{*}{ Atypical variants } & Matlab (type 1) & - & r & - & $r$ & $t$ & $\mathrm{Cla}_{\mathrm{a}}$ & $\mathrm{Cla}$ & B1 \\
\hline & Matlab (type II) & $\sim$ & s & - & r & s & $\mathrm{Cla}$ & EI & $\mathrm{B3}$ \\
\hline & Matlab (type lii) & - & $r$ & - & $r$ & 8 & $\mathrm{Cla}$ & $C|a / E|$ & $B 1 / 83$ \\
\hline & Altered $\mathrm{El}$ Tor & + & $r$ & + & $r$ & 8 & $\mathrm{Er}$ & $\mathrm{Cl} S \mathrm{EI}$ & $B 1$ \\
\hline & Mozambique & + & $r$ & + & $r$ & s & E & $\mathrm{Cla}$ & B1 \\
\hline & Hybrid El Tor & + & $r$ & + & $r$ & 5 & El & ClaEl & $B 1$ \\
\hline
\end{tabular}

Tomado de (22)

El reciente serogrupo 0139 proviene de las cepas del biotipo El Tor con una modificación genética del lipopolisacárido y la adición de una cápsula a las cepas parentales mediante transferencia horizontal genómica del locus rfb (32).

\subsection{Biología Molecular de la toxina colérica}

La molécula de la CT consiste en una proteína heterogénea estructurada en dos subunidades: un oligómero de $56 \mathrm{kDa}$ compuesto por 5 subunidades B idénticas (de 8-10/11.6 kDa cada una) unidas circularmente (CTB o ligera) y una subunidad A de $28 \mathrm{kDa}$ toxoactiva (CTA o pesada). A su vez, la subunidad A está intregrada por dos cadenas polipeptídicas, la CTA1 y la CTA2. La CTA1 confiere toxigenicidad mediada, mientras que CTA2 tiene la función de insertar el CTA dentro del pentámero CTB (mediante enlace no-covalente) $(19,33,34)$.

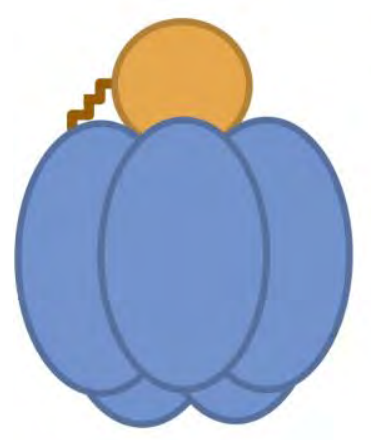

\section{A subunit enzymatic toxicity

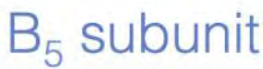 cell binding}

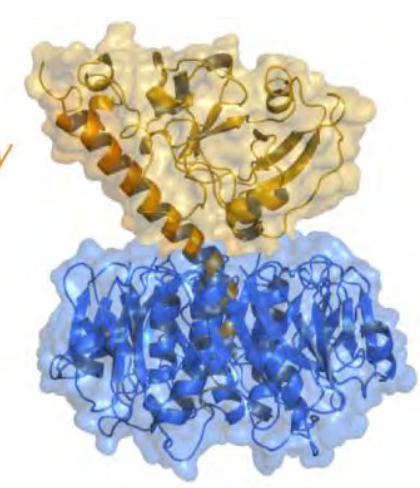

Figura 7. Representación de la estructura molecular de la toxina colérica.Tomado de (35). 
El Vibrio cholerae libera la CT, encontrándose más del 90\% de esta exoenterotoxina en forma extracelular y soluble. Una vez en el lumen del intestino delgado, la CT se internaliza en los enterocitos del hospedador a través del receptor ganglósido GM1, para el cual la CTB tiene una afinidad muy alta, siendo por tanto esta subunidad ligera la responsable de la unión celular. Como se ha mencionado en el apartado anterior, las secuencias de la CTA son idénticas para las cepas del Clásico y El Tor mientras que la secuencia de la CTB varía en dos nucleótidos. De cualquier manera, estos residuos no forman parte de la unión al GM1 ni influencian su afinidad (29).

Una vez endocitada, la CT viaja por transmisión retrógrada hasta el retículo endoplasmático, donde CTA y CTB se disocian. La CTA1 se trasloca al citosol donde cataliza la reacción de ribosilación del ADP con la subunidad Gsa de la adenilatociclasa resultando en un incremento del AMP-cíclico. Los niveles altos de AMPcíclico producen un desequilibrio en el flujo electrolítico a través de la membrana epitelial de la célula que se traduce en un aumento de la salida de cloro mediante el regulador de la conductancia transmembrana de la fibrosis quística (CFTR). Una inhibición de la absorción de sodio disminuye la captación de agua por la célula. Al mismo tiempo, un incremento de la exportación de cloro y bicarbonato producen un aumento de la salida de sodio, y por tanto de la secreción de agua por gradiente iónico. El efecto combinado produce una pérdida voluminosa de fluidos por el intestino del orden de 500 a $1000 \mathrm{ml} / \mathrm{h}$, que en casos extremos puede llegar a 3040 l por día. El 80-90\% de la secreción de fluido colérico ocurre en el primer metro del yeyuno proximal (36). 


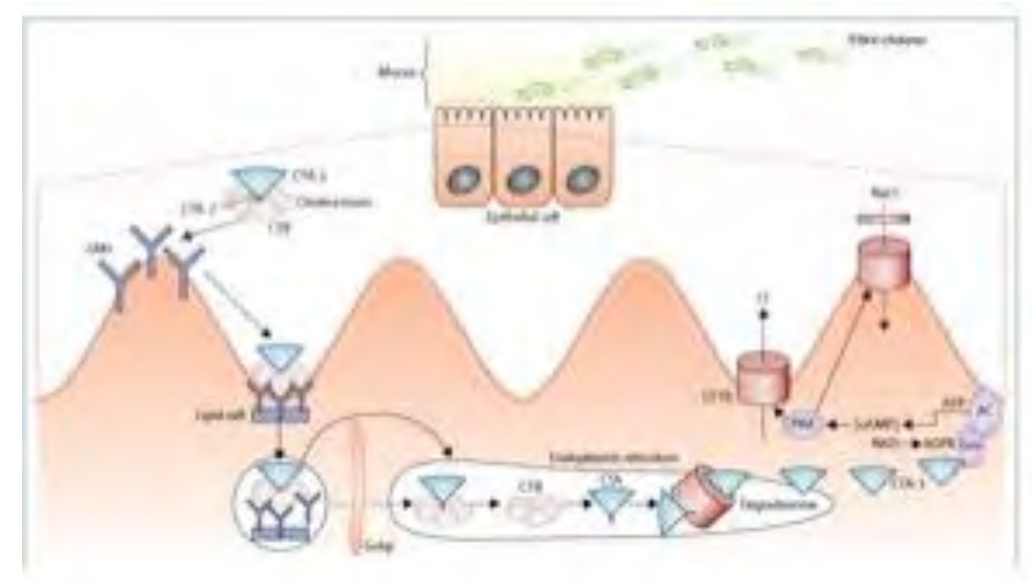

Figura 8. Mecanismo de acción de la toxina colérica. Tomado de (37)

El biotipo El Tor produce también la toxina RTX que contribuye a la patogénesis del $V C$ (37). Esta RTX no es producida por el biotipo Clásico.

\subsection{Respuesta inmunológica al Vibrio cholerae}

La infección por el Vibrio cholerae, aunque no es invasiva ni inflamatoria en cuanto a que no produce grandes cambios en la mucosa intestinal ni en la integridad del intestino delgado, induce una respuesta tanto frente a la CT como al lipopolisacárido (LPS) de la membrana de la bacteria, activando los dos tipos de respuesta inmunitaria: la innata y la adaptativa (o adquirida).

Durante la fase aguda, se produce la activación de citocinas proinflamatorias (incluyendo la interleucina-1 $\beta$ y el factor de necrosis tumoral), la expresión de diversas proteínas bactericidas y la migración de neutrófilos a la lamina propia. (38). La susceptibilidad al Vibrio cholerae depende de la variabilidad natural de la respuesta del sistema inmune innato (3).

Las células presentadoras de antígenos (APC), que fagocitan y procesan la bacteria, juegan un papel esencial en la iniciación de la inmunidad adaptativa mediante la activación de los linfocitos T CD3+ a través de la presentación del antígeno (Ag). La CTB facilita la presentación de ciertos Ags por los macrófagos y los enterocitos. 
Después de la fase inicial infecciosa, se desarrolla una inmunidad adaptativa de larga duración. La respuesta adaptativa incluye inmunoglobulina A secretora ( $\operatorname{IgA}$ ) producida localmente en el intestino, IgA sérica, IgG, anticuerpos (Ac) vibriocidas, células secretoras de Ac, células $\mathrm{T}$ y células $\mathrm{B}$ y $\mathrm{T}$ de memoria específicas para la protección a largo plazo. Las células CD3+ activadas producen factores humorales de inmunidad, como la IL-2, que actúa como factor de crecimiento de los linfocitos $\mathrm{T}$, amplificando la vigilancia de la inmunidad $\mathrm{Ag}$ dependiente. La inmunología del linfocito T es una compleja respuesta en cascada, que implica la maduración de las células CD3+CD4+ del estadío naïve a un estadío de memoria. Esto coincide con un cambio en la secreción de citocinas hacia la maduración y expansión de las células B que producen los Ac específicos frente al Ag "no propio" $(39,40)$. Aproximadamente 8 días depués del inicio de la infección se produce un pico de linfocitos circulantes específicos para el Ag de Vibrio cholerae que expresan los receptores de quimiocina en el intestino. Estos linfocitos pronto se vuelven indetectables en sangre, ya que regresan a la mucosa intestinal, donde llevan a un aumento de la sIgA, específica para CTP, LPS o la CTB. La mayoría de los Ac vibriocidas séricos son frente al LPS y actúan como marcadores de la presencia de Ac intestinales contra Ags específicos en la superficie bacteriana, en lugar de cómo mediadores de la protección (41). La respuesta tanto de los Ac séricos, como la de los Ac vibriocidas, alcanza un máximo entre 1 y 3 semanas después de la infección $(3,42)$.

Un año después de la infección, los Ac vibriocidas e IgA específica a la CT disminuyen hasta niveles basales. Aun así, en voluntarios sanos infectados con Vibrio cholerae, cuyos niveles de sIgA en la mucosa vuelven a niveles de referencia pasados unos meses, muestran una capacidad persistente para desarrollar una respuesta inmune anamnésica cuando vuelven a ser desafiados con Ags de Vibrio cholerae, desarrollando una secreción máxima de Ac intestinales a los tres días. Por lo tanto, es posible que la rapidez de la respuesta anamnésica en la reexposición pueda mediar en la protección contra el Vibrio más que la de los Ac preformados. De hecho, el Vibrio cholerae induce una respuesta de células B de memoria detectable durante al menos 1 año después de la infección (43-45). Se ha visto que personas que cohabitan con una persona que ha enfermado por cólera y que 
presentan células B de memoria especificas para el Ag-0 tienen un menor riesgo de infección por Vibrio cholerae, incluso sin evidencia de Ac vibriocidas circulantes en el tiempo de exposición(46).

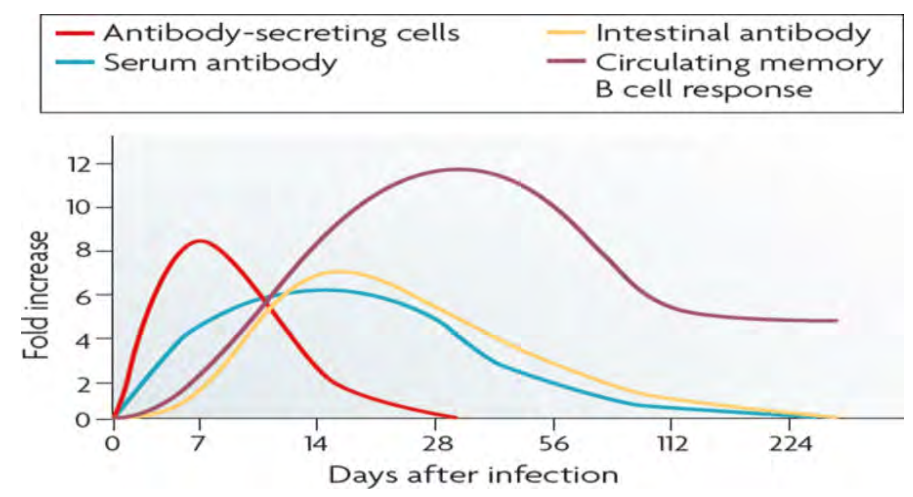

Figura 9. Progresión de Ac después de la infección por Vibrio cholerae. Tomado de (3)

Partiendo de la base que el Vibrio cholerae no penetra en la mucosa intestinal, solo los Ac antibacterianos y antitoxina presentes en el lumen intestinal o en la superficie de la mucosa pueden ser efectivos.

Los Ac antitoxinas actúan por inhibición de la unión de la CT al GM1 más que por interacción con la CTA. Los Ac IgG tienen una potencia neutralizadora mayor que la de la clase IgM, los cuales no tienen apenas efecto. El mecanismo de acción de los Ac vibriocidas está menos claro. Freter sugiere que estos Ac actuan por inhibición de la adhesión del Vibrio cholerae a la mucosa superficial además de incrementar el movimiento peristáltico que facilita la expulsión de vibrios y de la toxina. También los Ac vibriocidas podrían alterar la producción de CT. En cualquier caso, la respuesta inmunológica antibacteriana es fundamental para la inmunidad a largo plazo.

Independientemente del mecanismo de acción, los Ac IgG, IgA e IgM son capaces de mediar protección si estan presentes en el intestino. Sin embargo, el lugar de síntesis podria ser fuera del mismo, pudiendo derivar de la circulación sanguínea ya que se ha observado una correlación inversa entre títulos de Ac vibriocidas en zonas endémicas y la incidencia de la enfermedad (47). Varios artículos muestran 
una correlación entre el título de Ac vibriocidas y la protección frente Vibrio cholerae. $(48,49)$

Según estudios experimentales, no existe una protección cruzada entre los serogrupos 01 y 0139 (50), la protección es más pronunciada en la producida por la infección por el biotipo Clásico que por la de El Tor (51) y existe una protección cruzada contra el serotipo Inaba como Ogawa después de una infección por Inaba, mientras que la infección por Ogawa solo confiere protección contra su serotipo homólogo (52).

\subsection{Vacunas y uso en los últimos años}

La infección por cólera está extremadamente extendida en zonas endémicas, generalmente en forma subclínica. Durante la década de 1880, Koch y colegas observaron que personas que padecían una infección inicial por cólera quedaban protegidas contra infecciones posteriores durante la misma epidemia, sugiriendo el desarrollo de cierta inmunidad adquirida (53). Observaciones epidemiológicas en este sentido sugirieron imitar la inmunidad natural con cepas atenuadas de Vibrio cholerae como enfoque para el desarrollo de vacunas (54).

El creador de la primera vacuna frente al cólera fue el médico español Jaime Ferrán (1851-1929) a partir del cultivo de bacterias tomadas de una persona enferma por cólera durante la epidemia de 1884 en Marsella, donde fue enviado para estudiar el brote. Durante la epidemia de 1885 en España, inoculó con dicha vacuna a unas 50.000 personas en Valencia. Sin embargo, los informes de eficacia de la vacuna realizados por las comisiones científicas de aquella época mostraron resultados dispares y controvertidos ya que los cultivos utilizados contenían poca cantidad de V. cholerae y además presentaban otros microorganismos $(55,56)$.

Sawtschenko y Sabolotny desarrollaron la primera vacuna oral frente al cólera en 1893 cuando ellos y sus estudiantes ingirieron $V$. Cholerae cultivado en medio agar e inactivado con calor. Permanecieron asintomáticos después de infectarles con $V$. cholerae, pero a pesar de estos resultados, quedaban incógnitas sobre la 
pragmaticidad de la inmunización oral ya que se requerían múltiples dosis altas (53)

Durante los años 1920-1930 se llevaron a cabo en India ensayos clincos con Bilivaccine, una preparado comercial en forma de pastilla con 70 billones de $V$. cholerae. La pauta vacunal era de tres dosis durante tres días consecutivos. Aunque se demostró que proporcionaba una protección frente al cólera, se consideró inferior a la proporcionada por la vacuna parenteral. Con lo que se abandonó el método de la via oral (53).

La primera generación de vacunas frente al cólera fueron, por tanto, de administración parenteral y fueron utilizadas a lo largo del siglo XX. Durante los años 60 y 70 se realizaron estudios clínicos que encontraron que estas vacunas conferían una protección limitada (de alrededor del 50\%), de corto plazo (menos de 6 meses) y con frecuentes efectos secundarios (57). De hecho, la OMS catalogó la vacunación como medida ineficaz para el control del cólera en 1993.

Concluyendo con el apartado anterior, estudios posteriores revelaron que la base de la protección inmunológica frente al cólera parece ser que se encuentra en la mucosa intestinal $(56,58,59)$, de modo que el enfoque de inmunización oral parecía ser el más eficiente. En los últimos tiempos se han desarrollado vacunas orales contra el cólera tanto vivas (atenuadas genéticamente) como inactivadas $(4,60)$.

En contextos endémicos, las vacunas atenuadas no han mostrado mucha eficacia (61). Sin embargo, las vacunas orales inactivadas (OCV) han mostrado una protección de al menos 5 años usando la pauta de dos dosis (62). Además de aportar una protección directa a los individuos vacunados, las OCV confieren inmunidad indirecta (de rebaño), siendo una medida de Salud Púlbica muy costoefectiva (63).

En 2016, fecha en la que comienza el trabajo de campo de la presente tesis, cuatro formulaciones de vacunas orales se encontraban disponibles: 
- Dukoral ${ }^{\circledR}$ : Vacuna inactivada monovalente con células enteras inactivadas de Vibrio cholerae 01 y subunidad B de toxina colérica recombinante (WC-rBS). Producida por Valneva, Suecia. Comercializada en aproximadamente 60 países. Precalificada para uso internacional por la OMS en 2001.

- Shanchol ${ }^{\mathrm{TM}}$ : Vacuna inactivada bivalente con células enteras inactivadas de Vibrio cholerae 01 y 0139 (BivWC). Producida por Shantha Biotechnics, India. Autorizada en India (febrero 2009), Filipinas, Nepal, Malasia y Costa de Marfil. Precalificada para uso internacional por la OMS en noviembre 2011.

- mORC-VAX ${ }^{\mathrm{Tm}}$ : Vacuna inactivada bivalente con células enteras inactivadas de Vibrio cholerae 01 y 0139. Producida por Vabiotech, Vietnam. Autorizada sólo en Vietnam (2009).

- Euvichol ${ }^{\circledR}$ : Vacuna inactivada bivalente con células enteras inactivadas de Vibrio cholerae 01 y 0139. Producida por EuBiologics, Corea del Sur. Precalificada para uso internacional por la OMS en diciembre de 2015.

- OraVacs ${ }^{\mathrm{TM}}$ : Vacuna inactivada monovalente con células enteras inactivadas de Vibrio. cholerae 01 y subunidad B de toxina colérica recombinante. Producida por Shanghai United Cell Biotechnology, China. Autorizada en China y Filipinas.

- Vaxchora ${ }^{\mathrm{TM}}$ : Vacuna viva atenuada de Vibrio cholerae 01 Clásico Inaba cepa 569B (CVD 103-HgR). Producida por PaxVax, Estados Unidos de América (USA). Autorizada en Junio de 2016 en EUA.

\subsubsection{Dukoral ${ }^{\circledR}$}

Dukoral ${ }^{\circledR}$ se desarrolló en Suecia durante los años ochenta y fue la primera vacuna autorizada a nivel intenacional en 1991. Es una vacuna oral monovalente producida a partir de células enteras de Vibrio cholerae (Clásico y El Tor, Inaba y Ogawa), inactivadas por calor (el biotipo Clásico) y con formalina (el biotipo El Tor), y subunidad B de toxina cólerica recombinante (originalmente contenía la subunidad B de toxina cólerica nativa a partir de una cepa salvaje). La vacuna se administra con una solución tampón de bicarbonato sódico con la finalidad de proteger la toxina $\mathrm{B}$ de ser destruida por los ácidos gástricos. Produce una inmunización activa estimulando la produccion de sIgA y Ac antitoxina a nivel del intestino y se utiliza sobre todo para personas que viajan a áreas endémicas de 
cólera. La seguridad e inmunogenicidad han sido evaluadas en estudios postautorización, incluyendo individuos inmunodeprimidos y embarazadas (64).

La eficacia vacunal de Dukoral ${ }^{\circledR}$ frente al cólera ha sido evaluada en tres ensayos clínicos aleatorizados, doble ciego y controlados con placebo. Uno fue realizado en Bangladesh (región endémica) y dos en Perú (región no endémica). El estudio de Bangladesh (en Matlab) se realizó con 62.285 participantes entre 2 y 15 años y mujeres a partir de 15 años a los que se les administraron 3 dosis de vacuna versus placebo. La eficacia protectora de Dukoral ${ }^{\circledR}$ en la población general fue del 85\% (Intervalo de confianza (IC) del 95\%: 56-95) durante los seis meses iniciales de seguimiento. La duración de la protección conferida por la vacuna variaba según la edad, con una duración de seis meses en la población infantil (2-5 años) y de dos años en la población adulta. La eficacia fue más notoria frente al biotipo Clásico que El Tor. Este estudio también sugiere que, en las personas adultas, dos dosis de vacuna parecían ser tan eficaces como tres y que, aunque el componente de la subunidad B de toxina colérica confería una mejor inmunidad a corto plazo (especialmente en la población infantil), la parte celular de la vacuna era la responsable de la inmunidad de largo plazo (65-68). En el segundo ensayo clínico, realizado en Perú con reclutas del ejército entre 16-45 años, la eficacia protectora a corto plazo frente al cólera tras dos dosis de vacuna fue del 86\% (IC del 95\%: 3697)(69). El tercer estudio, un ensayo aleatorio de doble ciego realizado en Perú, no logró mostrar eficacia protectora de la vacuna (dos dosis) frente al cólera durante el primer año (debido a razones metodológicas (70)). Tras una dosis de recuerdo (tercera) al cabo de 10-12 meses de la inmunización primaria, la eficacia protectora durante el segundo año fue del 61\% (IC del 95\%: 28-79)(71).

La efectividad vacunal (EV) ha sido evaluada mediante estudios obervacionales durante dos campañas de vacunación masivas realizadas en Mozambique (diciembre de 2003 - enero de 2004) y en Zanzíbar (febrero de 2009 - mayo de 2010). En el estudio de casos y controles realizado en Mozambique, la efectividad de 2 dosis de Dukoral ${ }^{\circledR}$ fue del 84\% (IC del 95\%: 43-95) a los cinco meses de seguimiento (72). Todas las muestras de este estudio pertenecían a la cepa El Tor atípico (que produce la CT del Clásico) (27). En el análisis de cohorte longitudinal 
realizado en Zanzíbar, la eficacia protectora después de 2 dosis de Dukoral fue del 79\% (IC del 95\%: 47-92) durante un período de seguimiento de 15 meses. Además de la protección directa, se demostró que Dukoral ${ }^{\circledR}$ proporciona una protección indirecta (inmunidad de rebaño) significativa en las personas no vacunadas residentes en zonas con alta cobertura vacunal $(63,73)$. No conocemos estudios de la efectividad de Dukoral ${ }^{\circledR}$ tras la administración de una dosis de recuerdo.

\subsection{2 mORC-VAX ${ }^{\mathrm{TM}}$ y Shanchol ${ }^{\mathrm{TM}}$}

$\mathrm{ORC}$ VAX ${ }^{\mathrm{TM}}$ fue desarrollado en Vietnam a finales de los años 80 como vacuna inactivada monovalente con células enteras inactivadas de Vibrio cholerae 01. A diferencia de Dukoral ${ }^{\circledR}$ no requiere administrarse con una solución tampón puesto que no posee la subunidad B de toxina colérica recombinante.

Durante los años 90 se realizó un ensayo clínico en Vietnam que probó la seguridad de la vacuna con una eficacia del 66\% a los 8-10 meses. En 1997 se añadieron células enteras inactivadas de $V$. cholerae 0139 y fue autorizada en Vietnam como mORC-VAX ${ }^{\mathrm{m}}$, siendo la primera vacuna usada en poblaciones endémicas.

Un estudio observacional post-autorización durante la epidemia de cólera de 2003 en Hue (Vietnam) después de la vacunación entre 1998 y 2000 estimó una efectividad vacunal global a los 3-5 años de la vacunación del 50\% (IC del 95\%: 963) (74). Otro estudio durante la epidemia de cólera de Hanoi en 2007-2008 mostró una efectividad del 76\% (IC del 95\%: 5-94) a los 3-5 meses después de la campaña de vacunación sugiriendo que la vacuna podía proteger incluso después del comienzo de un brote (75).

La vacuna fue reformulada en 2004 en colaboración con el Instituto International de Vacuna (IVI) de Corea para cumplir con los requisitos de la OMS y de buenas prácticas de producción. Ensayos clínicos de fase II en Vietnam e India muestran que esta vacuna es segura e inmunogénica, con unos títulos de Acs mayores que los observados con ORC-VAX $(76,77)$. Un estudio aleatorizado y controlado con placebo con 66.900 personas mayores de 1 año de edad, en Calcuta en 2006, 
demostró una eficacia vacunal del $65 \%$ a los 3 años de seguimiento. Todos los episodios de cólera de este estudio pertenecían a la cepa El Tor atípico (78). En este estudio también se vió que la vacuna produce una protección indirecta 3 años después de la vacunación, probablemente debido a la reducción de la transmisión en la zona (79).

En 2009 fue autorizada en Vietnam como mORC-VAX ${ }^{\text {TM }}$ (donde forma parte del Programa Ampliado de Inmunización Nacional) y en India como Shanchol ${ }^{\mathrm{TM}}$ para producción nacional. En 2011 la OMS precalificó Shanchol ${ }^{\mathrm{TM}}$ para uso internacional. Se ha usado en Haiti, islas Salomón, Tailandia, Guinea y Sudán del Sur entre otros países (80).

\subsubsection{Euvichol ${ }^{\circledR}$}

Euvichol ${ }^{\circledR}$ presenta la misma formulación que Shanchol ${ }^{\mathrm{TM}}$ y mORC-VAX $^{\mathrm{TM}}$ pero producida por EuBiologics Co., Ltd.; laboratorio seleccionado por el programa "Iniciativa de Vacunas de Cólera" (CHOVI), financiado por la Fundación Bill y Melinda Gates y con la transferencia tecnológica del IVI, con el objetivo de aumentar el número de productores de vacuna frente al cólera para su uso en salud pública.

La vacuna tiene una vida útil de 24 meses a $2-8{ }^{\circ} \mathrm{C}$ y de 30 días a $37{ }^{\circ} \mathrm{C}$. La pauta vacunal consiste en dos dosis administradas con un intervalo de dos semanas. No require solución tampón. La diferencia entre Euvichol ${ }^{\circledR}$ y Euvichol-Plus ${ }^{\circledR}$ reside en la presentación, el primero en frascos de vidrio (como Shanchol ${ }^{\mathrm{TM}}$ ) y el segundo en viales de plástico, presentación más sencilla para la logística y administración de la vacuna (81).

Los ensayos clínicos precomerciales de fase I realizados en Corea en 2013 en 20 individuos sanos (hombres) confirmaron que la vacuna era segura, bien tolerada e inmunogénica. En un ensayo clínico para evaluar la seguridad con 2.999 personas sanas (de 1 a 40 años de edad), aparte de los efectos adversos raros o poco frecuentes ya descritos, no se produjo ningún efecto adverso grave durante el período de estudio. 
En 2014 se llevó a cabo un ensayo clínico controlado aleatorio en Filipinas. Se seleccionaron un total de 1.263 participantes (486 niños y niñas de 1 a 17 años y 777 personas adultas de 18 años y más). El estudio mostró que dos dosis de Euvichol® inducía una fuerte respuesta inmune a Vibrio cholerae 01 Inaba y 01 Ogawa en comparación con Shanchol ${ }^{\mathrm{TM}}$ tanto en la población infantil como adulta. La inmunidad a Vibrio cholerae 0139 fue menos pronunciada para ambas vacunas. No se informaron diferencias significativas en cuanto a eventos adversos (82). En diciembre de 2015 fue precalificada por la OMS.

\subsubsection{OraVacs ${ }^{\mathrm{TM}}$}

La fórmula de OraVacs $^{\mathrm{TM}}$ es la misma que Dukoral ${ }^{\circledR}$ con la diferencia de la forma farmacéutica, presentandose en cápsulas con recubrimiento entérico. Fue adquirida por el gobierno chino después del terremoto de 2008. Estudios preclínicos y datos de seguridad e inmunogenicidad estan disponibles en chino en la literatura. Sin embargo no hay disponible ninguna evaluación en cuanto a su eficacia. Está autorizada en China y Filipinas y su principal mercado es el de turistas (83).

\subsubsection{Vaxchora $^{\mathrm{TM}}$}

Esta vacuna viva atenuada fue producida a partir de una cepa de Vibrio cholerae 01 Inaba de la sexta pandemia por delección de la CTA y adición de un marcador de resistencia de mercurio. Se empezó a desarrollar en los años 80 y estuvo comercializada en los años 90 como Orochol $^{\circledR}$. Su producción se suspendió en 2003 por razones comerciales. Actualmente la produce PaxVax. Su eficacia fue evaluada a través de un ensayo clínico aleatorizado, doble ciego controlado por placebo en 197 personas entre 18 y 45 años infectadas posteriormente con Vibrio cholerae (84). En zonas endémicas la respuesta vibriocida es baja, con lo que requiere una cantidad más elevada de antígeno en su formulación. Está autorizada en USA para personas que viajan a países con transmisión activa de cólera.

\subsection{Contexto: Zambia}

La República de Zambia se encuentra al centro-sur de Africa y es un país interior limítrofe con Angola, República Democrática del Congo, Tanzania, Malawi, 
Mozambique, Zimbaue, Botsuana y Namibia. Se divide en 10 provincias, y cada una se fracciona en distritos, con un total de 105 a lo largo de todo el país.

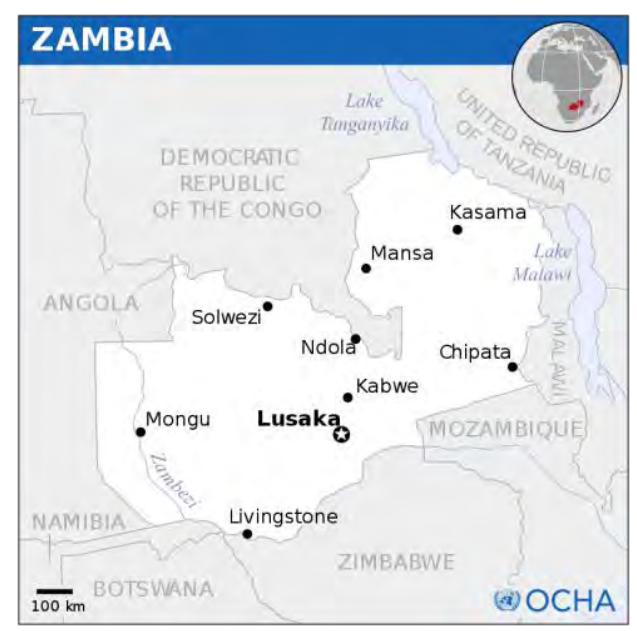

Figura 10. Mapa de Zambia

Zambia tiene una extensión de 752.614 kilómetros cuadrados, es fundamentalmente montañoso y presenta numerosas depresiones ocupadas por ríos y hundimientos tectónicos. La altitud media no supera los $1.500 \mathrm{~m}$. Al sur del país se encuentran las cataratas Victoria (Patrimonio de la Humanidad). Se caracteriza por tener un clima tropical con una estación seca de mayo a noviembre y de lluvias de noviembre a abril.

El país ha experimentado un rápido crecimiento económico en la última década siendo el segundo mayor productor de cobre de África, que representa el $90 \%$ del valor de las exportaciones.

La población en 2016 (proyección del censo de 2010) era de 15.933.883 habitantes y está compuesta por más de 70 grupos étnicos. El 44\% de la población vive en las ciudades o áreas urbanas. Salvo en la capital, Lusaka, el resto de principales urbes están en la región minera próxima a la República Democrática de el Congo (85).

\subsection{Cólera en Zambia}

El cólera es una enfermedad endémica en Zambia. El país ha registrado largos periodos con transmisión continuada con una recurrencia anual de 13.154 casos 
en 1991, 11.659 casos en 1992 y 11.327 casos en 1999. En respuesta al gran brote en 1999 el Ministerio de Salud (MS) de Zambia promovió la cloración de agua en las casas dentro del programa "Sistema de agua segura". Aunque no se reportaron casos en los siguientes tres años, a partir de noviembre de 2003 se volvieron a dar brotes anuales en Zambia afectando principalmente a la capital, Lusaka (86).

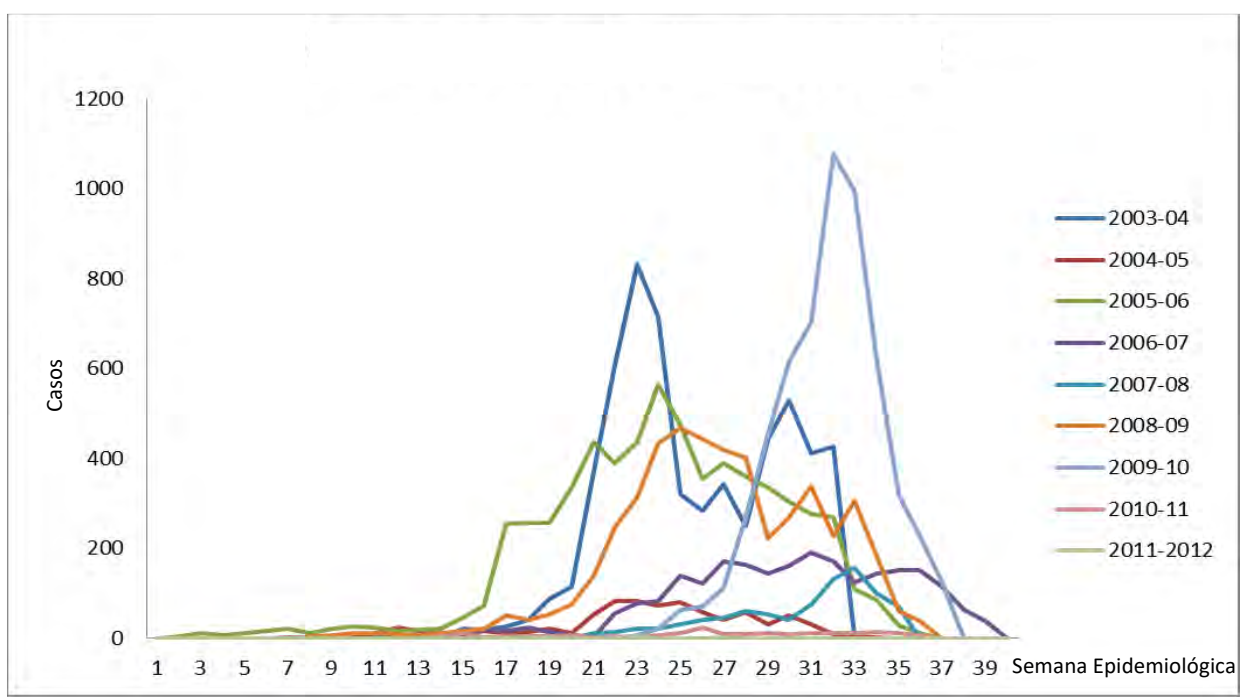

Figura 11. Curvas epidémicas de cólera en Lusaka durante el periodo 2003-2012

Tras 5 años sin notificación de casos de cólera confirmados (desde 2011), un brote comenzó el 4 de febrero de 2016 en Lusaka, alcanzando el pico en la semana epidemiológica 10. La cepa circulante identificada por laboratorio fue Vibrio cholerae 01 Ogawa. Este brote representaba una preocupación para las autoridades de salud pública ya que los niveles de protección natural contra el Vibrio cholerae podían haber disminuido en la población, pudiéndose disparar la magnitud de la epidemia.

El MS organizó una respuesta integral a la epidemia que incluia el manejo clínico de casos, el tratamiento farmacológico y las medidas de prevención a nivel de agua, saneamiento y educación para la higiene. Además el MS, con el apoyo de Médicos sin Fronteras (MSF) y la OMS, llevó a cabo una campaña de vacunación en respuesta al brote con el objetivo de interrumpir la transmisión de Vibrio cholerae en Lusaka y limitar así la probabilidad de propagación en el país. 
Históricamente, el riesgo de cólera es heterogéneo dentro de Lusaka, encontrándose la mayor carga de la enfermedad en los municipios de la parte occidental y norte de la ciudad. Esta población representaba alrededor de 500.000 personas (un 17\% de la población de Lusaka) y comprendía aquellas áreas con el menor acceso a agua potable, alcantarillado y saneamiento de la ciudad (87).

Debido a la gran cantidad de personas en riesgo y la escasez mundial de dosis de vacuna, el MS decidió implementar una estrategia de dosis única, en lugar de hacer una campaña de vacunación de dos dosis como se indica en la ficha técnica de las vacunas precalificadas por la OMS, para permitir que un mayor número de personas vulnerables se pudieran vacunar con las dosis disponibles. Esta decisión fue tomada de acuerdo con la evidencia disponible en el momento que sugería que el uso de una dosis de OCV podía aportar una protección a corto plazo y, que en contextos epidémicos con una limitación del stock de vacunas, podría ser una estrategia de elección preferible a la de dos dosis (88-92). Esta decisión dejaba abierta la posibilidad de completar el régimen de vacunación con una segunda dosis cuando el stock estuviera disponible. La segunda dosis se distribuyó 8 meses después. 
INTRODUCCIÓN | 46 



\section{JUSTIFICACIÓN}

En 1999, la OMS recomendó el uso preventivo de la vacuna oral frente al cólera en situaciones de emergencia con alto riesgo de producirse un brote de cólera y estableció una reserva de 2 millones de vacunas para su uso en situaciones de emergencia y endemicidad (93).

A pesar de que las pautas de tratamiento y prevención del cólera están adecuadamente establecidas y son bastante efectivas, el control del cólera sigue siendo deficiente tanto en contextos epidémicos como endémicos. La emergencia y persistencia de esta enfermedad refleja deficiencias en los programas de agua y saneamiento, limitaciones en la detección temprana y seguimiento de epidemias de los sistemas de vigilancia y en la accesibilidad a los servicios de salud.

Considerando dicha situación, la 64 Asamblea Mundial de la Salud apeló por una estrategia integral y ampliada para el control y prevención del cólera. En la resolución WHA 64.15 de 2011 se incluye la consideración de usar la vacuna frente al cólera "cuando sea apropiado, junto con los otros métodos recomendados de prevención y control y no como sustituto de los mismos" (94).

En 2013, la OMS estableció una reserva global de vacunas orales frente al cólera para garantizar su disponibilidad para el control del cólera en caso de brote o crisis humanitaria (95). Gavi, The Vaccine Alliance, se comprometió a financiar hasta 70 millones de dosis (aproximadamente 1,85\$ por dosis) entre 2014 a 2018 para ampliar el apoyo a la vacunación en contextos de emergencia y de no emergencia (en zonas de alto riesgo). Estas reservas, coincidiendo con la precalificación por la OMS de dos vacunas de bajo coste, Shanchol ${ }^{\mathrm{TM}}$ en 2011 y Euvichol ${ }^{\circledR}$ en 2015, allanaron el camino para aumentar el acceso y uso de la vacuna. Los países que deseen usar estas vacunas deben solicitarlas a través de dos mecanismos:

- Mecanismo de emergencia: a través del Grupo Coordinador Internacional (ICG)(96) formado por UNICEF, MSF, La Federación Internacional de la Cruz Roja y Sociedades de la Media Luna Roja (FICR) y la OMS. 
- Mecanismo de no emergencia: vía el Grupo de Trabajo Global para el Control del Cólera (GTFCC)(97), dispositivo de colaboración entre instituciones implicadas en el control del cólera creado a raíz de la WHA 64.15.

Debido a que esta reserva es limitada, las solicitudes son revisadas basadas en el riesgo de transmisión de cólera en el país demandante y otros factores contextuales, como la capacidad y compromiso para el control del cólera a largo plazo y más allá del uso de la vacuna. Existe una reserva mínima de vacunas para emergencias. Para las situaciones de no emergencia las dosis se van asignando en función de la disponibilidad restante.

Las vacunas orales frente al cólera se han convertido por tanto en una herramienta estándar de control y prevención del cólera. Sin embargo, las estimaciones de la eficacia y efectividad vacunal varían en función de la composición de la vacuna, la ubicación, el diseño del estudio y la duración del seguimiento. Por otro lado, las vacunas precalificadas por la OMS establecen un régimen de dos dosis con un intervalo de 2 semanas. Esto presenta desafíos para la toma de decisiones de salud pública para la realización de campañas de vacunación reactivas, oportunas y eficientes.

Un ejemplo de esto lo encontramos en la epidemia de cólera en Lusaka, Zambia, de 2016, en la cual el MS decidió incluir una campaña de vacunación reactiva dentro del paquete de medidas de lucha frente al brote. El stock de vacunas insuficiente para realizar dos dosis con un intervalo de dos semanas provocó que se decidiera vacunar con una dosis única en primera instancia. Esta situación también se produjo el año anterior en Juba (98), Sudán del Sur. Por tanto Zambia fue el segundo caso en que se ha utilizado una pauta de una dosis (a parte de un ensayo clinico en Bangladesh y posteriores utilizaciones en Haiti y Mozambique $(92,99))$.

Ante la escasez de vacunas precalificadas por la OMS para atender las necesidades epidémicas y endémicas de cólera mundiales (100), si una dosis de OCV provee una protección significativa, esta estrategia de vacunación sería más rentable y por tanto aumentaría la facilidad de uso de dicha estrategia para el control de brotes 
en contextos donde el stock de OCV es limitado. A la luz de la poca experiencia de implementación de este tipo de campañas para detener brotes en curso, la OMS recomienda documentar y difundir los resultados de estas intervenciones para ampliar el conocimiento del impacto de campañas de vacunación reactiva.

Esta situación presenta una oportunidad única para obtener nueva evidencia científica sobre la efectividad de este régimen para prevenir la enfermedad del cólera. Mediante este proyecto hemos pretendido contribuir en la generación de evidencia científica y establecer recomendaciones para la toma de decisiones hacia la lucha y control del cólera a través de:

- Una revisión sistemática de la literatura disponible y posterior metaanálisis para disponer de un resumen de la evidencia hasta el momento de eficacia y efectividad vacunal en general y de como puede variar según el contexto y la edad.

- Un estudio de efectividad vacunal en Zambia, con tres tipos de diseño, para entender la protección a corto plazo de una dosis de OCV Shanchol ${ }^{\mathrm{TM}}$ como parte de la estrategia de control de la epidemia.

- Una encuesta de cobertura después de la segunda ronda de la campaña de vacunación con OCV para evaluar la estrategia de ejecutar una primera ronda de vacunación para controlar el brote y una segunda ronda a los 8 meses para aumentar la duración de la protección e incrementar potencialmente la población inmunizada antes de la siguiente temporada de cólera. Esto podría permitir entender cuántas personas recibieron dos dosis de la vacuna y cuántas permanecen parcialmente vacunadas o no vacunadas antes del comienzo de la temporada de cólera 2017 en Lusaka. 
JUSTIFICACIÓN | 52 
OBJETIVOS 



\section{OBJETIVOS}

\subsection{Objetivo general}

Evaluar el uso de una dosis de vacuna oral inactivada en respuesta a la epidemia de cólera de 2016 en Zambia y la administración de la segunda dosis (8 meses después) para incrementar la duración de la protección de la vacuna.

Este objetivo global se aborda mediante los siguientes objetivos específicos.

\subsection{Objetivos específicos}

- Realización de una revisión sistemática y metanálisis de la literatura disponible para generar estimaciones promedio de eficacia y efectividad directa de la vacuna inactivada oral frente al cólera. (Ver Anexo 1: Publicación relacionada $\mathrm{n}$ ำ1)

○ Estimación de eficacia y efectividad vacunal global.

- Estimaciones en función del lugar.

○ Estimaciones en función del grupo de edad.

- Estimación de la efectividad a corto plazo de una dosis de vacuna oral frente al cólera como medida reactiva frente al brote de Lusaka, Zambia, en 2016. (Ver Anexo 1: Publicación relacionada nํ2)

- Determinar la protección a corto plazo de una dosis de vacuna oral frente al cólera Shanchol ${ }^{\mathrm{TM}}$.

- Evaluación de la cobertura vacunal de la campaña de vacunación en Lusaka, Zambia en 2016 con dos dosis en una pauta de intervalo de 8 meses. (Ver Anexo 1: Publicación relacionada nํ3).

- Evaluar la proporción de personas vacunadas con dos dosis.

- Evaluar el porcentaje de personas vacunadas con al menos una dosis.

- Evaluar la proporción de personas vacunadas con una dosis.

- Evaluar la proporción de personas vacunadas durante la primera ronda. 
- Evaluar la proporción de personas vacunadas durante la segunda ronda.

- Calcular la tasa de abandono en la segunda dosis.

- Evaluar la aceptabilidad de la intervención percibida por la población.

- Entender si la población diana continúa estable en los ocho meses entre ambas rondas de vacunación. 
MATERIALES Y MÉTODOS 



\section{MATERIALES Y MÉTODOS}

\subsection{Marco y diseño general del proyecto de investigación}

Este proyecto fue financiado por MSF (el estudio de eficacia vacunal) y la OMS (la revisión sistemática y meta-análisis y la encuesta de cobertura vacunal). El diseño, recogida de datos y análisis fue liderado por Epicentre. El protocolo del estudio fue aprobado por los comités de ética de la Universidad de Lusaka (Zambia) y la Escuela de Salud Pública de la Universidad Johns Hopkins (USA). La distribución de la vacuna y tratamiento contra el cólera fue gratuito. La participación en el estudio fue voluntaria mediante consentimiento firmado por la propia persona o por su tutor/a legal en el caso de los menores de edad. La privacidad y confidencialidad de los datos recogidos de las personas participantes fue garantizada durante y después del estudio.

El diseño del proyecto incluye tres components principales: la revisión de la evidencia científica sobre la protección de las vacunas orales frente al cólera y la generación de estimaciones promedio de eficacia y efectividad vacunal, el estudio de efectividad de una dosis de vacuna oral frente al cólera y la encuesta de cobertura vacunal tras la segunda dosis de vacuna.

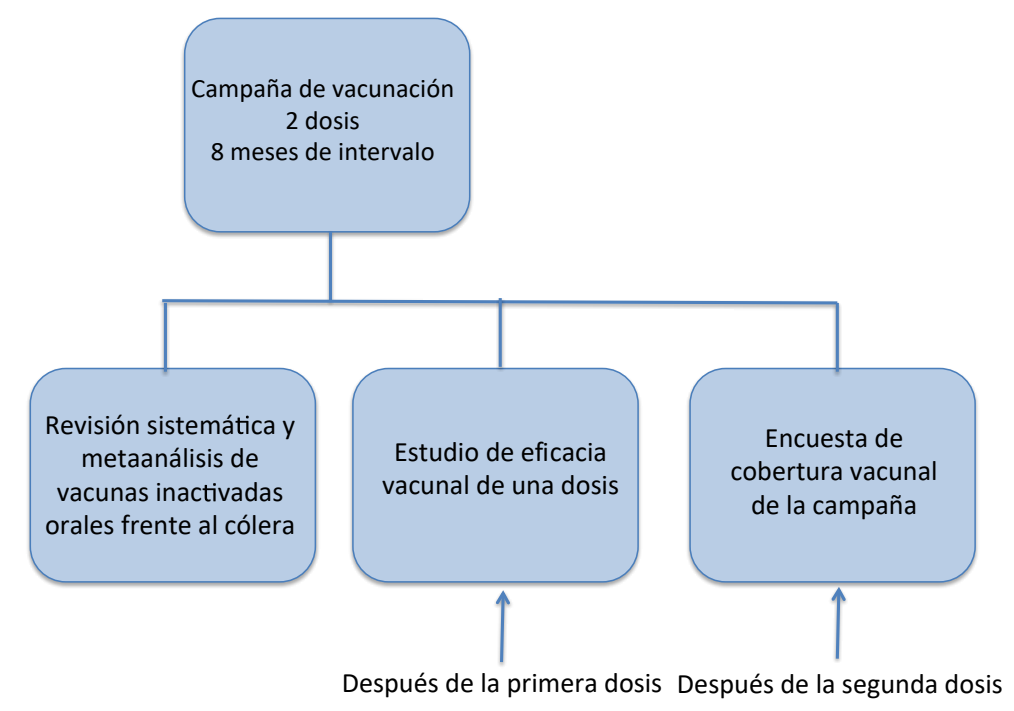

Figura 12. Diagrama resumen del diseño del proyecto de investigación 


\subsection{Revisión sistemática y meta-análisis de vacunas inactivadas orales frente al cólera}

\subsubsection{Estrategia de búsqueda y criterios de selección.}

Para la realización de la revisión sistemática y meta-análisis nos basamos en las directrices del protocolo PRISMA (Preferred Reporting Items for Systematic reviews and Meta-analyses for Protocols. http://www.prisma-statement.org/). Las directrices PRISMA se componen de una lista de 27 elementos de verificación que facilitan la preparación y presentación de un protocolo sólido para la revisión sistemática, garantizando la planificación previa de la revisión y promoviendo, por tanto, un trabajo coherente, íntegro y transparente.

La búsqueda bibliográfica fue realizada a través de las bases de datos PubMed, Embase, Scopus y Cochrane Review Library el 9 de julio de 2016 y en ISI Web of Science el 11 de julio de 2016. Las palabras clave que utilizamos fueron: "cólera" y "vacuna" y ("eficacia" o "eficacia" o "protección") en el título o resumen. En la búsqueda inicial no pusimos restricciones en la fecha de publicación o idioma. Para identificar publicaciones adicionales consultamos a la GTFCC.

Dos revisoras (Qifang Bi y Eva Ferreras) evaluamos de forma independiente cada resúmen para su inclusión en la revisión del artículo completo. Las diferencias fueron resueltas mediante discusión y consenso. Revisamos resúmenes en inglés, español, francés y chino. Cada artículo se categorizó y se seleccionó para la revisión de texto completo si reportaban eficacia vacunal total o directa mediante un ensayo clínico aleatorizado (ECA) o efectividad vacunal mediante un estudio observacional. Los duplicados fueron eliminados antes de la revisión del resúmen utilizando el software covidence.

\subsubsection{Definiciones}

- Eficacia vacunal: Reducción relativa del riesgo de infección por cólera confirmado médicamente en individuos que recibieron la vacuna versus los que no la recibieron, estimada mediante un ECA. 
- Efectividad vacunal: Reducción relativa del riesgo de infección por cólera confirmado médicamente en individuos que recibieron la vacuna frente a los que no la recibieron, estimada mediante un estudio de casos y controles, de cohortes o de caso-cohorte.

- Cólera confirmado: Presencia de Vibrio cholerae en heces o frotis rectal determinado por PCR, cultivo o prueba de diagnóstico rápido.

\subsubsection{Análisis de los datos}

Durante el proceso de revisión del texto completo, ambas revisoras extrajimos las estimaciones primarias de efectividad o eficacia vacunal, total o directa, y las incorporamos a una base de datos electrónica, de forma independiente. Las diferencias fueron resueltas mediante discusión y consenso. Excluimos de la extracción las estimaciones procedentes de análisis secundarios de los estudios (p. ej., reanálisis presentados en manuscritos separados) utilizando métodos estadísticos alternativos o medidas de protección. Los datos relevantes fueron obtenidos del texto, figuras y tablas. Nos pusimos en contacto con los autores cuando faltaban datos.

Se obtuvieron estimaciones por número de dosis de vacuna, duración y grupo de edad. Los resultados principales de estos meta-análisis fueron la eficacia y efectividad promedio de dos dosis de OCV. Dadas las estimaciones diversas, y con frecuencia los manuscritos múltiples de cada estudio, enfocamos los análisis primarios en las estimaciones de protección de dos dosis reflejando la duración del punto final primario. Para cada estimación, se extrajeron los siguientes datos: diseño del estudio, lugar del estudio, criterios de inclusión, tipo de vacuna (BivWC o WC-rBS), fechas de la campaña de vacunación, tiempo de seguimiento, método para la confirmación de los casos, tipo de estimador (de eficacia o de efectividad vacunal), IC del 95\%, número de pacientes o controles vacunados o no vacunados, número de dosis, intervalo entre dosis (si hubiera más de una), cobertura vacunal, distribución de la edad de los casos y distribución de los serotipos y biotipos de los casos. 
El riesgo de sesgo para cada estudio fue evaluado por dos revisores (Qifang Bi y Andrew Azman), de forma independiente, empleando la Escala de NewcastleOttawa para los estudios observacionales y la herramienta de la Colaboración Cochrane para los ECA. Para evaluar el sesgo de publicación se produjeron gráficos en embudo con los resultados primarios (dos dosis).

A partir de las estimaciones puntuales de eficacia y efectividad vacunal reportadas y los IC al 95\%, calculamos el error estándar para cada una de las estimaciones. Para los estudios que reportaron IC unilaterales, reconstruimos IC al 95\% bilaterales usando métodos estándar (asintóticos)(101). Estimamos la eficacia y efectividad vacunal promedio por separado, en función de estos errores estándar, utilizando modelos de efectos aleatorios con el estimador empírico de Bayes de la varianza entre estudios ( $\tau 2$ ) usando el paquete metafor en R $(102,103)$. Evaluamos la heterogeneidad utilizando el estadístico $\mathrm{I}^{2}$, que se interpreta como la proporción de la variación total en las estimaciones debida a la heterogeneidad entre estudios más que a la varianza en el muestreo (103). Evaluamos las diferencias entre subgrupos (p. ej., tipo de vacuna, grupo de edad o número de dosis) mediante el ajuste de modelos de meta-regresión lineales incluyendo el subgrupo como un moderador, e hicimos la prueba de Wald para estimar el efecto del subgrupo (104). Dado que los estimadores individuales de la protección vacunal corresponden a la protección en diferentes marcos temporales de la vacunación, calculamos la duración media ponderada de la varianza inversa de cada estimador promedio para ayudar a la interpretación de nuestros resultados.

Exploramos la asociación entre los estimadores de protección vacunal, la edad media de los casos y la duración del estudio a través de la valoración visual de las relaciones y modelos de regresión lineal con funciones splines polinomiales. En uno de los estudios que reportó estimadores de cada uno de los 5 años de seguimiento(62), usamos un modelo de regresión lineal con el logaritmo de la mediana de la edad de los pacientes como variable independiente para estimar la asociación con la eficacia vacunal. 
Este estudio está registrado en el registro de revisión sistemática PROSPERO (2016: CRD42016048232). (105)

\subsection{Población objeto de estudio}

La campaña de vacunación con OCV comenzó el 9 de abril, cuando se alcanzó el pico de la epidemia en Bauleni (semana epidemiológica 14), y terminó el 23 de abril (semana epidemiológica 16). Cuatro áreas fueron seleccionadas para la campaña teniendo en cuenta las tasas de ataque de cólera de la epidemia en curso y el histórico de epidemias de cólera en Lusaka. Las áreas escogidas fueron Bauleni, Kanyama (compuesto por los municipios de Kanyama West, Old Kanyama, New Kanyama y John Laing), George (George-Soweto y George) y Chawama (Misisi-Kuku, John Howard y Chawama).

La vacunación fue dirigida a todos los individuos a partir de 12 meses de edad y residentes en los municipios citados en el párrafo anterior. Al final de la campaña se administraron un total de 424.100 dosis con una cobertura administrativa total de las zonas seleccionadas del 73,4\%. (106).

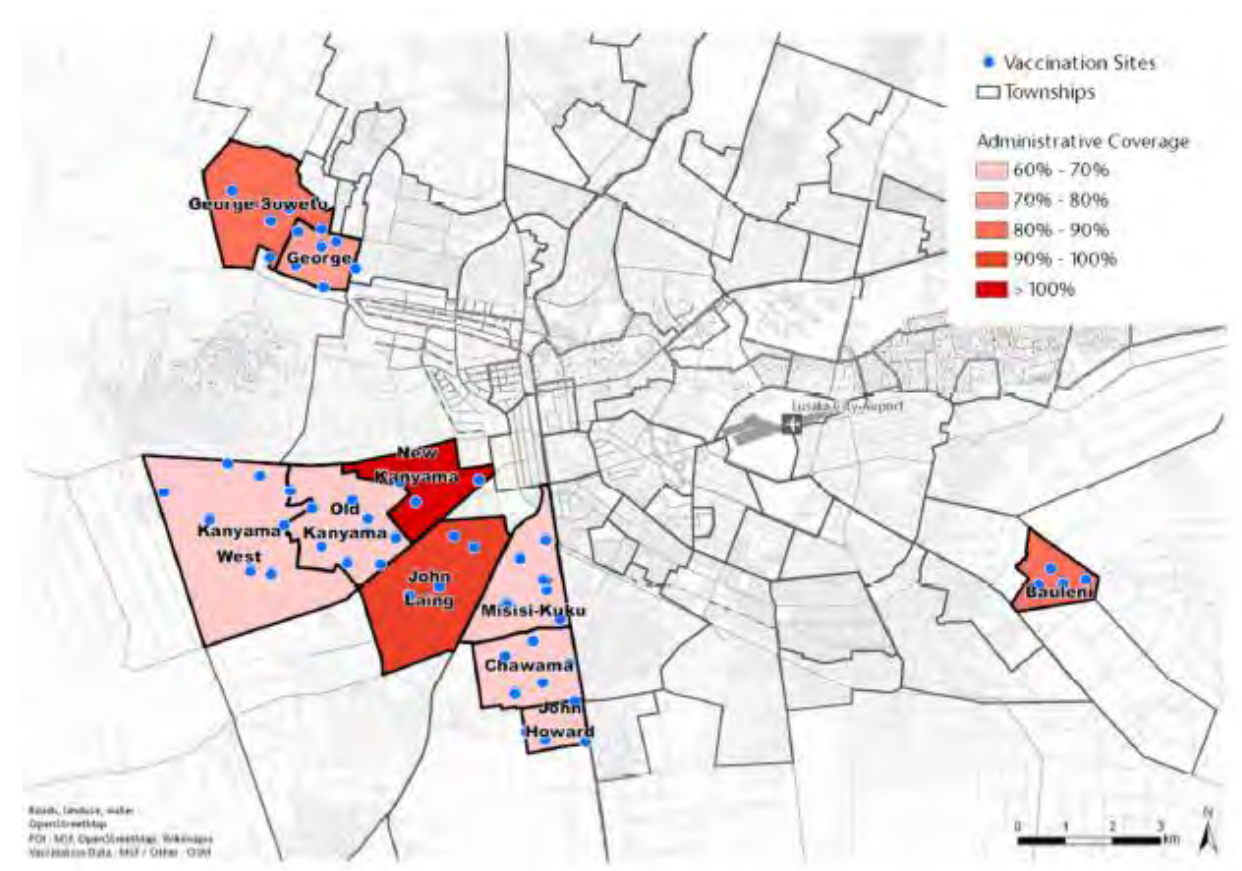

Figura 13. Áreas perceptoras de la campaña masiva de vacunación frente al cólera en Lusaka, Zambia, 2016 y coberturas administrativas. Tomado de (107) 
La población objeto del estudio incluía a todos los individuos elegibles para la campaña de vacunación y que residían (definido como dormir y comer durante al menos las dos semanas previas) en las áreas de Bauleni, Kanyama, Chawama y George durante la primera ronda (para el estudio de efectividad vacunal y la encuesta de cobertura vacunal tras la primera ronda) y durante la segunda ronda (para la encuesta de cobertura vacunal tras la finalización de las dos rondas de la campaña)

\subsection{Estudio de eficacia vacunal de una dosis}

\subsubsection{Vigilancia de cólera}

El cólera es una de las 24 enfermedades bajo vigilancia semanal e incluida en el Sistema de Alerta Temprana (ver Anexo 2). Los centros de salud notifican semanalmente a la oficina de salud de su distrito correspondiente, éstas a su vez a la oficina de salud provincial que notifica al departamento de vigilancia del Instituto Nacional de Salud Pública de Zambia.

Las áreas con alto riesgo de infección por Vibrio cholerae en Lusaka están definidas a partir de datos históricos de la enfermedad y de acceso a sistemas de agua potable y saneamiento adecuado, representando aproximadamente el 35\% de la población de la capital, situada principalmente en las áreas periurbanas occidentales (87). El sistema de vigilancia fue reforzado en los cinco centros de tratamiento de cólera (CTC) ubicados en Kanyama, Bauleni, Chawama, Matero y George (figura 15) desde el 14 de abril de 2016 hasta el final del brote. Estas clínicas cubrían todas las áreas con alto riesgo en Lusaka y proporcionaban tratamiento gratuito. Se implementó un sistema de notificación temprana basado en el uso estandarizado de la definición de caso sospechoso y el uso de registros específicos para cólera. El personal médico fue formado en la definición de caso, la importancia de la notificación inmediata y sistemática de cada caso sospechoso, en el uso de registros y en la recogida y transporte de muestras de heces. Dichas muestras eran enviadas al laboratorio del CTC de Kanyama para la realización de pruebas de test rápido y cultivo; así como la preparación para el envío de muestras para el análisis por reacción en cadena de la polimerasa (PCR). 


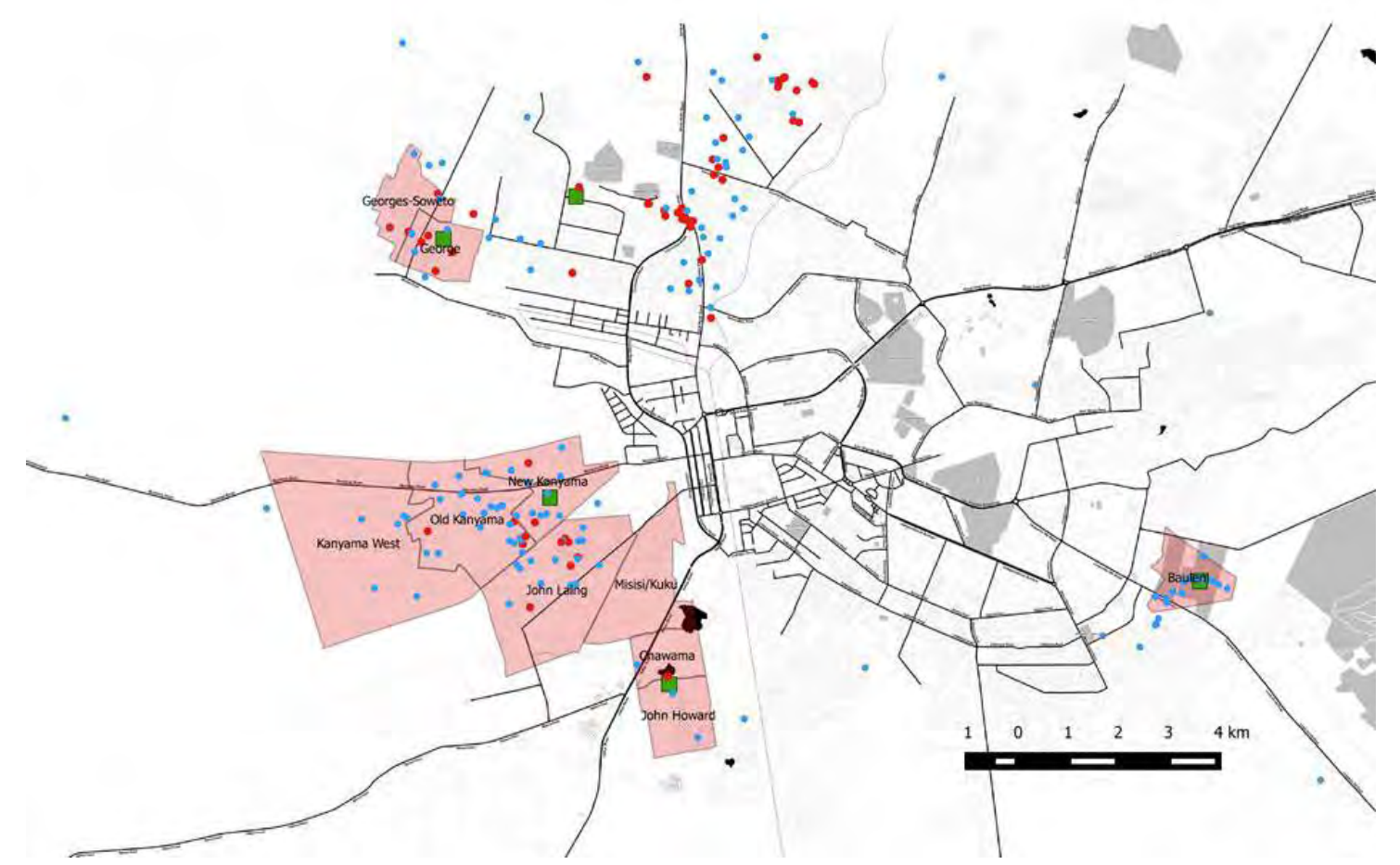

Figura 14. Mapa de Lusaka por municipios

En puntos azules los casos de diarrea no colérica, en puntos rojos lo casos confirmados de cólera, en puntos verdes los CTC y en rosa las áreas seleccionadas para la campaña de vacunación con OCV.

La definición de caso sospechoso utilizada fue la siguiente: diarrea acuosa, aguda y no sanguinolenta, con más de 3 deposiciones en las últimas 24 horas.

De cada caso sospechoso se recogia la siguiente información: fecha de admisión, fecha de aparición de los síntomas, edad, sexo, localidad, grado de deshidratación en la admisión, fecha de alta, estatus (recuperado, abandono, transferido o fallecido) y resultado del test de diagnóstico rápido (RDT).

\subsubsection{Diseño del estudio}

En situación de epidemia, el diseño más común para evaluar la efectividad vacunal de forma observacional es el de casos y controles ya que en enfermedades poco frecuentes el odds ratio (OR) aproxima el riesgo relativo (RR) y por tanto se puede usar para estimar la EV (108).

En nuestro estudio empleamos tres tipos de diseños:

- Casos y controles pareado (MCC), 
- Test-negativo de casos y controles (TNCC),

- Caso-cohorte (CC).

En la redacción del borrador del plan de análisis previo al estudio decidimos que el estudio de casos y controles pareado serviría para el analisis primario si reclutabamos al menos 40 casos confirmados y si no, usariamos el de caso-cohorte ya que tiene mayor poder estadístico con tamaños muestrales pequeños. Además realizamos un diseño de test-negativo de casos y controles para controlar por el posible sesgo de búsqueda de atención sanitaria entre los individuos vacunados y no vacunados (109). Este posible sesgo también fue evaluado mediante un análisis del indicador de sesgo.

\subsubsection{Definición y selección de los participantes del estudio}

Consideramos como caso sospechoso de cólera cualquier persona ingresada en uno de los CTC por diarrea acuosa aguda entre el 25 de abril y la declaración oficial del final del brote (15 de junio de 2016).

Todos los casos sospechosos eran elegibles para ser incluidos como participantes del estudio siempre que proporcionaran su consentimiento por escrito (ver Anexo 3) y cumplieran con los siguientes requesitos:

- Ser residente en el área de estudio desde el 9 de abril de 2016 (primer día de la campaña de vacunación).

- Ser mayor de 12 meses a 9 de abril de 2016.

- Que la diarrea comenzara después del 9 de abril de 2016.

- Producir al menos tres deposiciones acuosas en las 24 horas posteriores al inicio de la diarrea.

- Su residencia fuera localizable por el equipo del estudio tras el alta del paciente.

En el caso de que un paciente tuviera más de un episodio de diarrea acuosa aguda durante el periodo de estudio, solo se incluía el primer episodio en el mismo. 
Se recogieron muestras de heces de todos los casos sospechosos que aceptaron a participar en el estudio para realizar las pruebas confirmatorias por cultivo y PCR (consultar la sección de procedimientos de laboratorio para más detalles)

En función de los resultados de laboratorio, los casos sospechosos se dividían en dos grupos:

- Caso confirmado de cólera: aquellos positivos a cultivo y/o PCR

- Caso sospechoso con diarrea no colérica: aquellos negativos a cultivo y PCR

Por cada caso se seleccionaron cinco personas de control de forma sistemática en el vecindario del caso. Para ello, comenzando con el primer hogar a la derecha de la casa del caso, ibamos visitando todas las casas consecutivas hasta que identificabamos un control elegible, reclutándo una persona por hogar.

Una persona del mismo vecindario, sexo y grupo de edad (1-4, 5-9, 10-19, 20-29, 30-39 y $\geq 40$ años) que el caso sospechoso de cólera era elegible para ser un control pareado si:

- No había buscado tratamiento para la diarrea entre el 1 de enero de 2016 y la fecha de inicio de la diarrea de su caso pareado;

- Y habría buscado tratamiento en un CTC si hubiera desarrollado diarrea acuosa severa.

La elegibilidad para la selección de los controles también requería los mismos criterios de consentimiento, residencia y edad que los aplicados a los casos.

Para el análisis primario se usaron los controles pareados con los casos confirmados. Para evaluar si los resultados de la efectividad podrían atribuirse a un sesgo, se compararon los casos sospechosos con diarrea no cólerica con sus correspondientes controles (análisis del indicador de sesgo) 
Los miembros de la cohorte eran individuos seleccionados al azar procendentes de las áreas consideradas de alto riesgo de transmisión de cólera (algunas de ellas seleccionadas y otras no por la campaña reactiva de OCV) en una cantidad proporcional al tamaño de la población del municipio proveniente. Los hogares fueron seleccionados aleatoriamente, seleccionando puntos GPS en polígonos georreferenciados en los límites del municipio. Los participantes tenían los mismos criterios de elegibilidad que los descritos anteriormente.

En la Figura 17 se muestra un diagrama de flujo que explica la inclusión de los participantes en el estudio.

\subsubsection{Procedimiento del estudio}

A cada caso sospechoso que aceptaba participar en el estudio se le realizaba una entrevista en el CTC. Después de entrevistar al caso, se seleccionaban cinco controles entre el vecindario y se les entrevistaban en sus casas dentro de la misma semana de la entrevista de su caso correspondiente. El equipo del estudio ignoraba cuales de los casos sopechosos eran confirmados para V cholerae ni como se iba a usar la información sobre el estado vacunal en el análisis.

Entre el 17 de abril y el 25 de mayo de 2016, reclutamos una cohorte de 906 individuos. Una vez en el hogar, se elegía una persona al azar (110). El equipo de investigación hizo un seguimiento de los participantes hasta el 24 de Julio de 2016 (final del estudio). La ocurrencia de episodios de diarrea (con o sin ingreso en un centro de salud), y el estado vacunal de los individuos que no se habían vacunado previamente era chequeado durante el seguimiento. Consideramos como casos aquellos participantes del estudio registrados en el registro nacional de casos sospechosos de cólera al final del estudio.

\subsubsection{Verificación del estado vacunal $y$ de variables potencialmente confusoras.}

Las variables del estado vacunal, datos clínicos, demográficos, socioeconómicos y ambientales eran recogidas a través de un cuestionario estructurado y 
administrado a todos los paticipantes del estudio por medio de tabletas usando el software Kobo Toolbox 1.4.8 (Cambridge, MA, USA) y por un equipo capacitado de entrevistadores y entrevistadoras.

Las entrevistas se realizaron de forma presencial en los CTC (a los casos) y en las casas (a los controles y miembros de la cohorte). A los participantes se les preguntaba si se habían vacunado durante la campaña de inmunización mostrándoles fotos de un vial y de una persona adulta tomando la vacuna, y aportando detalles de la campaña para asegurar la adecuada identificación de la vacuna. A aquellas personas que reportaban haber sido vacunadas, se les preguntaban si habían recibido el carné de vacunación y en caso afirmativo dicho carné era verificado y fotografiado si estaba disponible. Para aquellas personas que reportaban haber sido vacunadas pero que no estaban en posesión del carné de vacunación, el estado vacunal era registrado como autorreportado.

Consideramos a un individuo vacunado si reportaba haber recibido la vacuna al menos 7 días antes del inicio de los síntomas (o de su caso correspondiente si la persona entrevistada era un control).

\subsubsection{Procedimientos de laboratorio}

Por cada caso sospechoso se recogía una muestra de heces en un cubo nuevo (no usado previamente ni limpiado con lejía) y era trasladada al laboratorio de la clinica de Kanyama donde se realizaba el RDT y el cultivo con las heces frescas. Además, se recogían dos gotas de la muestra fecal en papel de filtro (Whatman 903) para la realización de análisis de la PCR. También se inoculaban unos 50 mg de heces en $5 \mathrm{ml}$ de agua peptonada alcalina (APW) y se incubaban a $37^{\circ} \mathrm{C}$ durante 4-6 horas y se repetían los tres procedimientos (cultivo, RDT e inoculación de papel de filtro) con este medio enriquecido. 


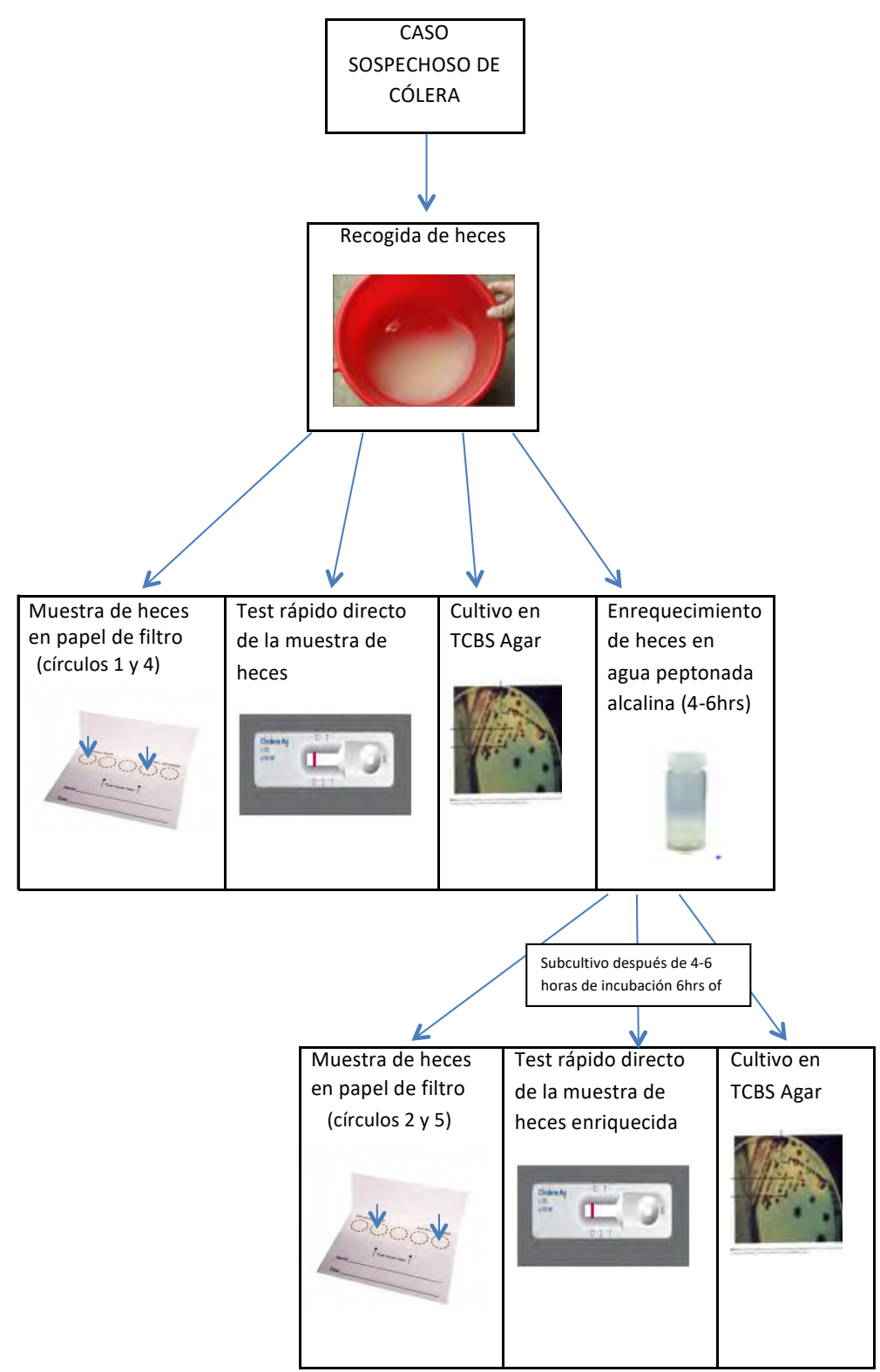

Figura 15. Descripción de las diferentes muestras recogidas para cultivo, test rápido y análisis de PCR

Las pruebas de diagnóstico rápido (directo en las heces y después del enriquecimiento en APW) se realizaron in situ por el personal técnico de laboratorio del estudio, con el objetivo de tener una monitorización de las inclusiones del estudio a tiempo real, pero no se usaron para la confirmación de los casos debido a la información limitada sobre el rendimiento del SD Bioline. Con los datos obtenidos se hizo una evaluación del SD Bioline comparándolo con el cultivo (método estándar para la confirmación) y la PCR. Para más información sobre los resultados de dicha evaluación consultar el artículo relacionado "Evaluation of the 
SD bioline cholera rapid diagnostic test during the 2016 cholera outbreak in Lusaka, Zambia" en el Anexo 1: Publicaciones relacionadas.

Para definir los casos confirmados de cólera y casos de diarrea acuosa no colérica se usó el cultivo y la PCR. El cultivo se realizó en el laboratorio de la clínica Kanyama bajo la supervisión del Hospital Universitario de Lusaka (UTH) usando métodos estandard. (111). Se realizan dos cultivos por cada muestra en medio TCBS (agar tiosulfato-citrato-bilis-sacarosa), una con las heces frescas y otra con las heces enriquecidas con APW. Con las colonias sugestivas de Vibrio cholerae en TCBS se realizó un sub-cultivo en medio agar Mueller-Hinton (MH). Las colonias que crecieron en el medio $\mathrm{MH}$ se serotiparon usando antisuero polivalente 01 , 0139, 01 Inaba y 01 Ogawa.

La PCR se realizó en el UTH y en el Instituto Pasteur de Paris en paralelo (como garantía de control de calidad) utilizando las muestras en el papel de filtro de Whatman 903 seco. En un microtubo, se introducía un círculo del papel de filtro que contenía dos gotas de heces frescas y se rehidrataba con $150 \mu \mathrm{L}$ de agua estéril. Luego se añadía $200 \mu \mathrm{L}$ de solución de Chelex al 2\% y se agitaba con vórtex a alta velocidad. Se hervía durante 8 minutos y centrifugaba durante 2 minutos. La PCR se realizaba con $2 \mu \mathrm{L}$ del sobrenadante para detectar un espaciador intergénico en una región específica del Vibrio cholerae (gen ISR) . En las muestras positivas para Vibrio cholerae, se amplificó el gen $r f b$ para la identificación de los serogrupos 01 y 0139, como se describe Hoshino et al (112). En muestras negativas, se repitió la PCR para Vibrio cholerae con $4 \mu \mathrm{L}$ de sobrenadante. Si volvia a salir negativo, se realizaba una PCR de ARN 16S para evaluar la presencia de ADN y/o inhibidores de PCR. Ver Anexo 4: Algoritmo para la confirmación por PCR.

\subsubsection{Análisis estadístico}

En el análisis primario se evaluaba la protección conferida por una dosis de vacuna oral frente al cólera confirmado por cultivo o PCR a través de un diseño de casos y controles pareado. Además usamos otros dos enfoques analíticos: el del testnegativo de casos y controles y el del caso-cohorte. 


\subsubsection{Análisis de casos y controles (MCC y TNCC)}

En el diseño de MCC y el del TNCC, comparamos las probabilidades de vacunación entre los casos confirmados y los sujetos control (pareados o con diarrea no colérica según el diseño) por medio de modelos de regresión logística condicional univariable y multivariable. Calculamos el nivel de protección de la vacuna como: $\mathrm{EV}=(1-\mathrm{OR}) \times 100$

En el MCC, para detectar un 75\% de efectividad vacunal (basado en el metaanálisis), con una dosis de OCV, con una potencia del $80 \%$ y un error alfa del 5\%, calculamos que necesitabamos reclutar 29 casos y 145 controles (con una relación 1:5).

Comparamos factores de riesgo demográficos, ambientales y socioeconómicos para la transmisión de cólera, entre los casos y sus controles para explorar su potencial efecto confusor sobre la protección vacunal. Definimos como posibles variables confusoras aquellas asociadas con el evento de interés (cólera confirmado) y con la exposición (vacunación con OCV). Desde un planteamiento conservador, consideramos que las variables están "asociadas" cuando el valor de p para la variable en el modelo univariado (para el evento de interés o para la exposición) era inferior a 0,2. También contemplamos como posibles variables de confusión aquellas que modificaran la EV en más del $5 \%$ en los modelos bivariados. Todas estas posibles variables confusoras las incluimos en el modelo multivariado ajustado final. Todos los valores de p y el IC al 95\% fueron bilaterales. Determinamos como significación estadística valores de p inferiores a 0,05.

Además realizamos análisis estratificados por edad, gravedad (grado de deshidratación) y por cobertura vacunal a nivel local para explorar por las principales interacciones.

\subsubsection{Análisis de caso-cohorte}

Para el diseño del caso-cohorte, contando con un 15\% de pérdidas de seguimiento de las participantes y que un $2 \%$ de la muestra presentara cólera, reclutaríamos 
909 (775 x $1.15 \times 1.02)$ personas seleccionadas de las áreas consideradas con alto riesgo de transmisión de cólera (algunas de las áreas fueron seleccionadas para la campaña de vacunación y otras no).

Estimamos el cociente de riesgo (HR) de cólera (atendido médicamente) comparando aquellos que recibieron la vacuna con los que no la recibieron. La EV se calculó mediante la fórmula: $\mathrm{EV}=(1-\mathrm{HR}) \times 100$. Desarrollamos modelos de riesgo proporcionales de Cox con el estado vacunal como variable independiente y un tiempo origen del 9 de abril de 2016 (el primer día de la campaña de vacunación). Los casos que no vinieran de la cohorte contribuían una personatiempo de 0.01 dias antes del inicio de sus síntomas siguiendo el estándar para los análisis de caso-cohorte (113). De forma conservativa, los individuos de la cohorte que reportaron diarrea durante el seguimiento pero sin evidencia de cólera confirmado (cruzando datos con el registro nacional de cólera) permanecían "en riesgo" de cólera después de la fecha de la diarrea. Exploramos el incumplimiento de la no proporcionalidad de los riesgos de forma visual y mediante regresión lineal generalizada de residuos de Schoenfeld del estado vacunal a través del logaritmo del tiempo. (114)

\subsubsection{Análisis de indicador de sesgo}

El estudio primario de MCC fue diseñado para minimizar el sesgo y la confusión. Aun así, implementamos un análisis de indicador de sesgo anidado para detectar posibles sesgos relacionados con diferencias en la búsqueda de atención sanitaria, si estuvieran presentes. Puesto que no esperabamos que la vacuna confiriese protección contra la diarrea no colérica, en el análisis de indicador de sesgo esperabamos una asociación nula entre la vacuna y la diarrea no colérica. La selección de los casos en el análisis de indicador de sesgo era la definida en la sección de Definición y selección de los participantes del estudio como caso sospechoso con diarrea no colérica. Por cada caso se seleccionaron 5 controles pareados por vecindario, sexo y grupo de edad (al igual que en el MCC). Para analizar el posible sesgo, desarrollamos el análisis de indicador de sesgo mediante 
modelos de regresión logística condicinal ajustados y crudos, al igual que en el MCC.

\subsubsection{Análisis de datos faltantes (missings)}

Exploramos tres estrategias diferentes para el tratamiento de los datos faltantes en el análisis multivariante:

\section{Método de eliminación de observaciones:}

Consiste en eliminar toda la información del resgistro del individuo en el que falte algún dato de alguna de las variables de interés.

\section{Métodos que utilización de todos los datos disponibles:}

Consiste en utilizar toda la información, tanto de los casos completos como incompletos, considerando los datos faltantes como una variable ficticia dummy.

\section{Método de imputación de los datos faltantes}

Consiste en reemplazar cada valor faltante por un conjunto de $n$ valores, obteniéndose así $n$ conjuntos completos de datos, lo que da lugar a $n$ estimaciones con sus respectivas varianzas o errores estándar. Entonces, se combinan las estimaciones dando lugar a estimaciones e IC que incorporan la incertidumbre causada por la pérdida de datos.

Para ello usamos la técnica de imputación multiple por ecuaciones encadenadas (MICE) que básicamente actualiza una a una las variables con datos faltantes según series completas de distribuciones condicionadas. $(115,116)$. Siguiendo este proceso, creamos 100 conjuntos de bases de datos imputados que utilizamos para los análisis multivariados.

\subsection{Encuesta de cobertura de la campaña de vacunación.}

\subsubsection{Diseño del estudio}

Una vez finalizada la primera ronda de la campaña de vacunación, se hizo una estimación de la cobertura vacunal usando una sub-cohorte de las áreas seleccionadas para la campaña procedente de la cohorte. Después de la segunda 
ronda se realizó una segunda encuesta transversal para estimar la cobertura del total de la campaña.

La población del estudio incluía a todos los individuos mayores de 12 meses residentes en Bauleni, Kanyama, John Laing, Chawama y George durante la segunda ronda de vacunación (del 16 al 24 de diciembre de 2016). Los residentes se definieron como personas que vivían (dormir y comer) en estos municipios durante al menos las dos semanas anteriores.

Para el cálculo del tamaño muestral, consideramos que el $50 \%$ de las personas recibirían las dos dosis, con un intervalo de confianza al 95\% (equivalente a un error alfa del 5\%) y una precisión del 5\%. Puesto que se trataba de una muestra aleatoria simple, no era necesario tener en cuenta el efecto de diseño. Suponiendo un 15\% de datos faltantes, planeamos visitar 442 hogares. Un hogar se definió como un grupo de personas que dormían bajo el mismo techo y compartían las comidas todos los días durante al menos las dos semanas anteriores.

La selección de la muestra representativa de la población fue mediante muestreo espacial (110) para ambas encuestas. Para ello generábamos un punto aleatorio en el área de muestreo que reteníamos si coincidía con un hogar (con un error de +/10 metros). El proceso se repetía hasta alcanzar el tamaño muestral final. En cada hogar se seleccionaba, con ayuda de un software en la tableta, un individuo al azar entre todos los individuos elegibles que formaban parte del hogar en el momento de la encuesta. Si la persona seleccionada no cumplía con los criterios de elegibilidad, se seleccionaba el siguiente hogar de la derecha. Si la persona seleccionada se negaba a participar, se generaba un nuevo punto aleatorio.

\subsubsection{Recogida de datos}

La recogida de datos se realizó mediante un cuestionario estandarizado y se llevó a cabo por tres equipos formados por 3 personas encuestadoras y 1 líder de grupo capacitadas en los procedimientos del estudio y recopilación de datos.

Cada encuestador/a disponía de una lista de coordenadas GPS de los hogares seleccionados por muestreo aleatorio espacial. En cada hogar seleccionado, se 
seleccionaba un individuo al azar entre los componentes del hogar con al menos 1 año de edad. Los equipos realizaban entrevistas personales después de obtener el consentimiento por escrito. Se recogían datos demográficos (edad, sexo y tamaño del hogar), estatus vacunal (autorreportado y confirmado mediante el carné de vacunación), razones para la no vacunación (pregunta abierta) y datos de aceptabilidad (eventos adversos, gusto y creencias sobre la vacuna)

Si la persona seleccionada estaba ausente en el hogar, se organizaba una segunda visita más tarde durante el mismo día o en un segundo día. Si durante la segunda visita no se podía encontrar a la persona seleccionada o ésta se negaba a participar, se saltaba ese hogar.

Se registraron todas las visitas, ausencias y rechazos. Se utilizó un cuestionario estandarizado para recopilar información demográfica (edad, sexo y tamaño del hogar), sobre la recepción y disponibilidad del carné de vacunación en el momento de la encuesta, el estado vacunal (autorreportado y confirmado por la tarjeta), razones para la no vacunación (pregunta abierta) y datos de aceptabilidad (eventos adversos, gusto y creencias sobre la vacuna).

\subsubsection{Análisis de los datos}

El principal resultado de la encuesta fue la cobertura de la segunda dosis de OCV en la población diana. Estimamos intervalos de confianza del 95\% (test exacto de Fisher). La cobertura de la vacuna se calculó:

$$
\left(\frac{N o \text { individuos que reportaron ser vacunados }}{\text { Población de la encuesta }} \times 100\right)
$$

La cobertura de vacunación incluyó tanto la vacunación confirmada con el carné como la autorreportada. 
Además, calculamos la cobertura vacunal con dos dosis (pauta completa), con al menos una dosis y la cobertura vacunal de la primera ronda. La tasa de abandono entre ambas rondas se calculó de la siguiente manera:

$$
\left(\frac{N^{\mathrm{o}} \text { vacunados en la } 1^{\underline{a}} \text { ronda }-N \text { oovacunados durante la } 1^{\underline{a}} \text { y } 2^{\underline{a}} \text { ronda }}{N^{\underline{0}} \text { vacunados en la } 1^{\underline{a}} \text { ronda }} \times 100\right)
$$

Los indicadores sobre la aceptabilidad de la campaña de vacunación se centraron en las razones de la no vacunación y los eventos de efectos secundarios entre los participantes. Los indicadores se calcularon como proporciones con intervalos de confianza al 95\%. Para generar los mapas, utilizamos la regresión logística con funciones spline en un marco general de modelos aditivos.

\subsection{Herramientas para la recogida y análisis de los datos}

Los datos del studio fueron recogidos mediante cuestionarios electrónicos usando el software Kobo Toolbox 1.4.8 (Cambridge, MA, USA). El análisis de los datos se hizo mediante el software estadístico R, versión 3.2.3. 
MATERIALES Y MÉTODOS | 78 
RESULTADOS 



\section{RESULTADOS}

\subsection{Revisión sistemática y meta-análisis de vacunas inactivadas orales frente al cólera}

Identificamos 6.224 documentos potencialmente elegibles para la evaluación; 6.223 mediante búsqueda bibliográfica usando como palabras clave en el resúmen o título "cólera" y "vacuna" y "eficacia" /"efectividad" /"protección", y uno mediante sugerencia de experto. Tras la eliminación de duplicados y de enlaces obsoletos nos quedamos con 2.257 resúmenes para revisar la publicación entera, de las cuales 34 fueron elegibles para la evaluación del texto completo y, de éstas, 19 cumplian los criterios de inclusión para la extracción de datos. Al final de este proceso, extrajimos datos de 7 ensayos clínicos (5 realizados en Asia y dos en América del Sur) $(62,65,66,69,71,78,92,117-122)$ y 6 estudios observacionales (4 realizados en Africa, 1 en Asia y 1 en el Caribe) $(72,73,88-90,123)$

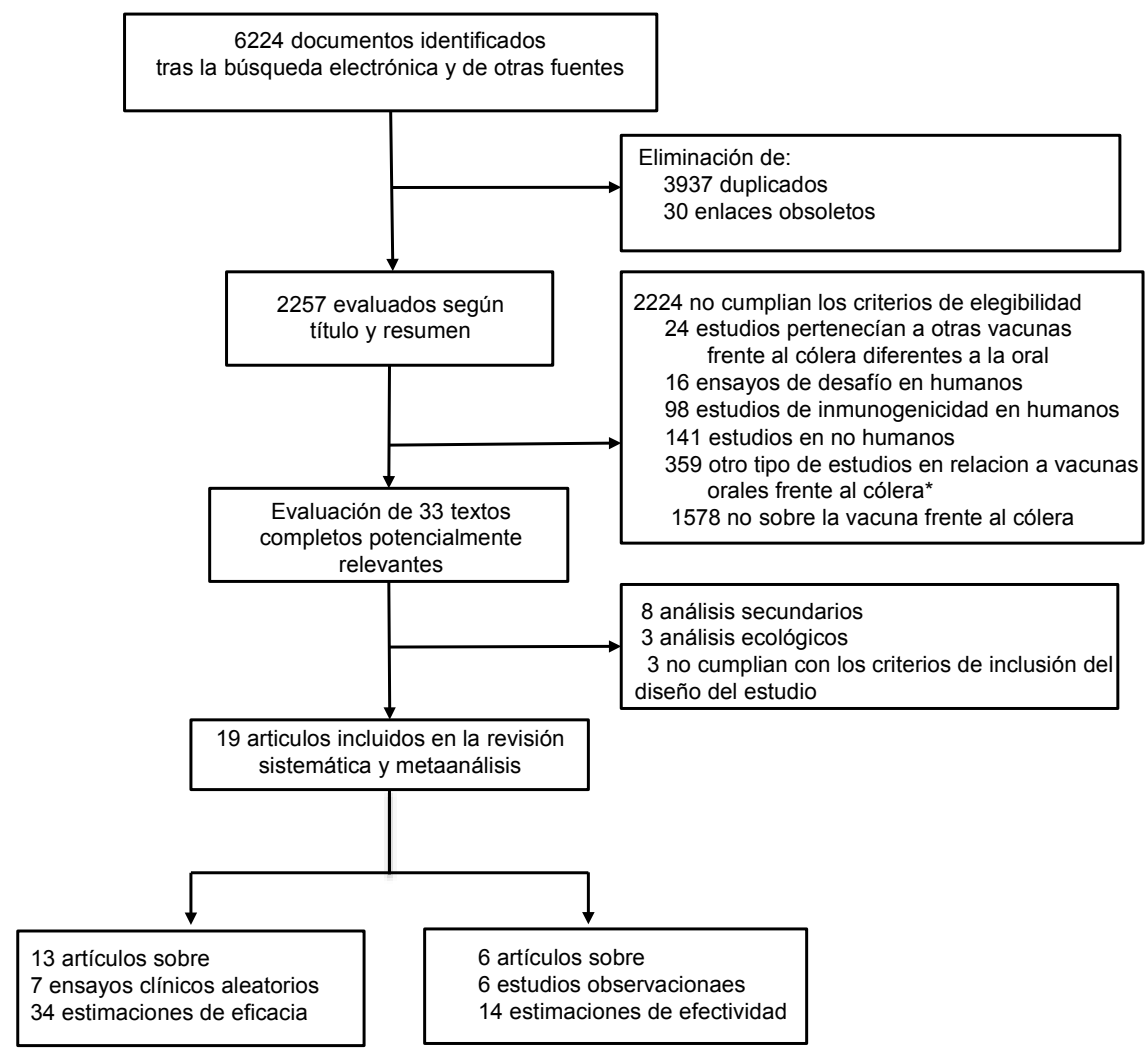

Figura 16. Diagrama de flujo PRISMA con los detalles de la revisión sistemática y el proceso de extracción de datos. * comentarios, revisiones, información para toma de decisiones de 
política de salud pública, estudios de modelización y estudios relacionados con cualquiera de las vacunas frente al cólera cuyo evento es diarrea no colérica.

\subsubsection{Descripción de los ensayos clínicos}

Cinco de los siete ensayos clínicos eran aleatorizados y controlados con placebo $(66,69,71,92,118)$ y dos sin placebo $(117,122)$. La aletaorización fue a nivel individual y de hogar o vecindario $(62,117,122)$. En todos los estudios la enfermedad fue confirmada por cultivo para Vibrio cholerae. En dos de los ensayos la variable principal de estudio fue la toma con una pauta de tres dosis $(63,68)$, cuatro usaron dos dosis $(62,69,117,122)$ y uno usó una dosis $(89)$. El intervalo de tiempo entre la primera y la segunda dosis en los ensayos estaba entre 14 y 42 días $(59,63)$.

Tabla 3. Resumen de los estudios de eficacia vacunal que cumplían los criterios de inclusión en su análisis principal

\begin{tabular}{|c|c|c|c|c|c|c|c|c|}
\hline & Lugar & Diseño del estudio & Vacuna & $\begin{array}{c}\text { Duración del } \\
\text { estimador(es)* }\end{array}$ & № dosis & Población & Serotipos & $\begin{array}{l}\text { № pacientes } \\
\text { con cóleraף }\end{array}$ \\
\hline Sur et al & Kolkata, India & $\begin{array}{c}\text { ECA vecindario y } \\
\text { controlado con placebo }\end{array}$ & BivWC & 2,3 y 5 años & 2 & $\begin{array}{c}\text { Personas no } \\
\text { embarazaras } \\
\text { mayores de } 1 \text { año }\end{array}$ & $\begin{array}{l}\text { Inaba y } \\
\text { Ogawa }\end{array}$ & 166 \\
\hline Taylor et al & Lima, Peru & $\begin{array}{c}\text { ECA individual } \\
\text { y controlado con placebo }\end{array}$ & BivWC & 2 años & 3 & $\begin{array}{l}\text { Personas no } \\
\text { embarazaras } \\
\text { entre } 2 \text { y } 65 \text { años }\end{array}$ & $\begin{array}{l}\text { Inaba y } \\
\text { Ogawa }\end{array}$ & 7 \\
\hline Sanchez et al & Lima, Peru & $\begin{array}{c}\text { ECA individual y } \\
\text { controlado con placebo }\end{array}$ & BivWC & 5 meses & 2 & $\begin{array}{l}\text { Reclutas hombres } \\
\text { entre } 17 \text { y } 65 \text { años }\end{array}$ & $\begin{array}{c}\text { Sin } \\
\text { información }\end{array}$ & 16 \\
\hline Clemens et al & Matlab, Bangladesh & $\begin{array}{c}\text { ECA individual y } \\
\text { controlado con placebo }\end{array}$ & $\begin{array}{l}\text { BivWC o } \\
\text { WC-rBs }\end{array}$ & $\begin{array}{l}6 \text { meses y } 1, \\
3(P) \text { y } 4 \text { años }\end{array}$ & 3 & $\begin{array}{l}\text { Menores entre } 2-15 \\
\text { años y mujeres } \\
\text { mayores de } 15 \text { años } \\
\text { no embarazadas }\end{array}$ & $\begin{array}{l}\text { Inaba y } \\
\text { Ogawa }\end{array}$ & 81 y $68 ¥$ \\
\hline Quadri et al§ & Dhaka, Bangladesh & ECA vecindario & WC-rBs & 2 años & 2 & $\begin{array}{c}\text { Personas no } \\
\text { embarazaras } \\
\text { mayores de } 1 \text { año }\end{array}$ & $\begin{array}{l}\text { Inaba y } \\
\text { Ogawa }\end{array}$ & 139 \\
\hline Quadri et al & Dhaka, Bangladesh & $\begin{array}{c}\text { ECA individual } \\
\text { y controlado con placebo }\end{array}$ & WC-rBs & 6 meses & 1 & $\begin{array}{c}\text { Personas no } \\
\text { embarazaras } \\
\text { mayores de } 1 \text { año }\end{array}$ & $\begin{array}{l}\text { Inaba y } \\
\text { Ogawa }\end{array}$ & 101 \\
\hline Trach et al & Hue, Vietnam & ECA vecindario & WC-rBs & 10 meses & 2 & $\begin{array}{l}\text { Personas a partir de } \\
\qquad 1 \text { año }\end{array}$ & Ogawa & 117 \\
\hline
\end{tabular}

*Cuando las estimaciones contienen múltiples duraciones (por ej, tiempo desde la vacunación), el estimador principal se marca con una (P). Algunas de las publicaciones notificaban estimadores multiples con diferente duraciones acumulativas. Hemos incluido las duraciones del estimador principal. đNúmero total de pacientes con cólera tanto de los grupos vacunados como de placebo. ¥Eficacia vacunal con al menos una dosis; 81 con WC-rBS y 68 con BivWC. § El estudio no tenía grupo placebo así que usamos el grupo no intervenido como grupo de comparación. Los 139 pacientes se refieren a los pacientes en la vacunación, el grupo de intervención sólo se usó para evaluar la protección total. 
Dos de los estudios presentaban un riesgo de sesgo bajo en todos los dominios de calidad del estudio $(92,118)$, tres presentaban un riesgo bajo en casi todos los dominios pero con al menos un área con riesgo poco claro de sesgo $(69,71,119)$ y uno presentaba al menos un dominio con riesgo de sesgo alto $(117,122)$

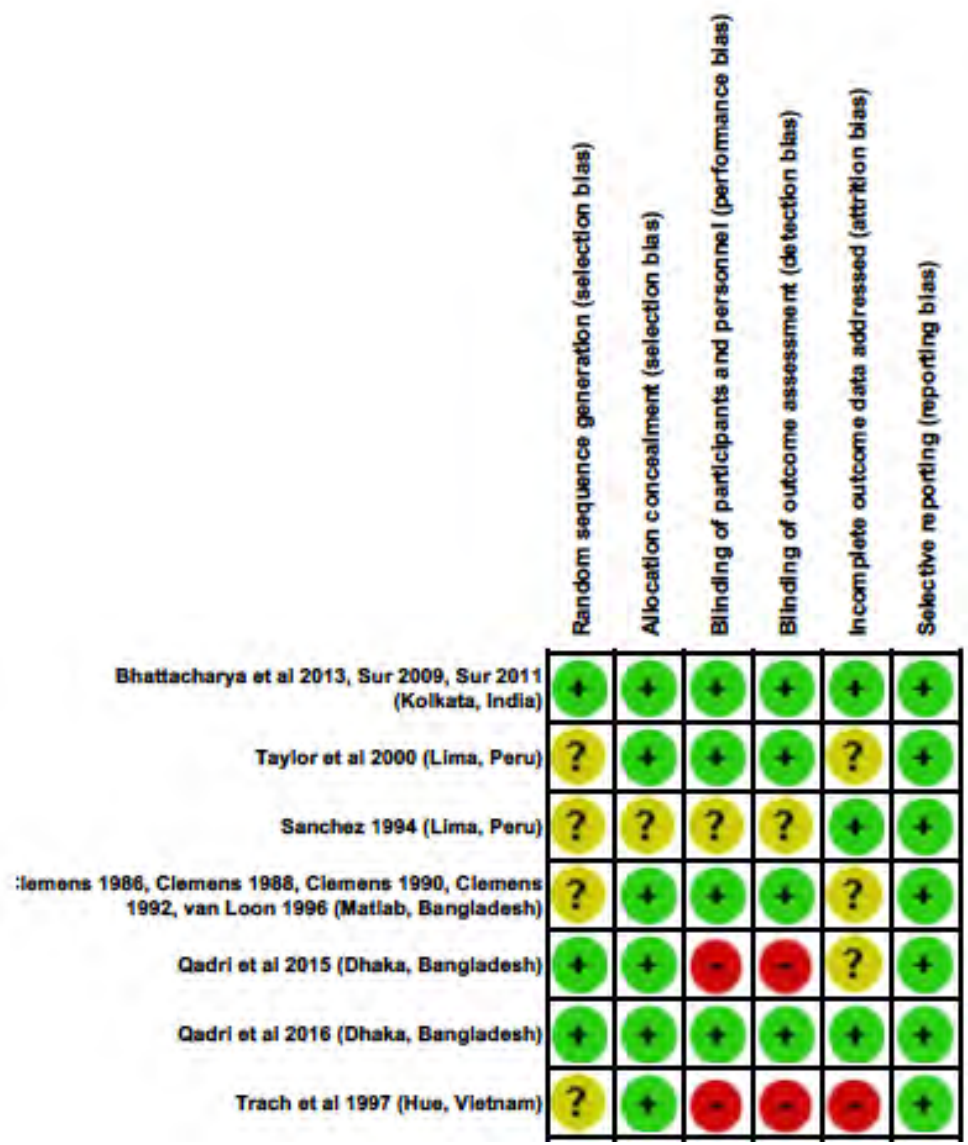

Figura 17. Resumen del riesgo de sesgos para ensayos clínicos siguiendo la herramienta de Cochrane Collaboration. El punto verde representan riesgo bajo de sesgo, el Amarillo riesgo no claro de sesgo y el rojo riesgo alto de sesgo. Tomado de (105)

\subsubsection{Descripción de los estudios observacionales}

De los seis estudios de efectividad elegibles, cuatro eran estudios de casos y controles $(72,88,89,123)$, uno de cohorte (73) y otro de caso-cohorte (90). La mayoria de los estudios reclutaban individuos que buscaban tratamiento por diarrea en un centro de salud (que formaba dentro del estudio) y que cumplían con la definición de caso sospechoso de cólera de la OMS, siendo confirmado posteriormente mediante cultivo de heces, excepto en dos de los estudios en los cuales se usaron técnicas de PCR (90) y de test rápido(89) para la confirmación. En los estudios de casos y controles, tres de los estudios usaban controles 
comunitarios $(72,88,89)$ y uno controles hospitalarios con diarrea no colérica (123). La variable principal de estudio fue el régimen con dos dosis, excepto en uno de los estudios que estimaba la efectividad con una sóla dosis (90). El intervalo de tiempo entre las dos dosis variaba entre 12 a 25 días $(72,73)$

Tabla 4. Resumen de los estudios de efectividad vacunal que cumplían los criterios de inclusión en su análisis principal

\begin{tabular}{|c|c|c|c|c|c|c|c|c|}
\hline & Lugar & Diseño del estudio & Vacuna & $\begin{array}{l}\text { Duración del } \\
\text { estimador }\end{array}$ & № dosis & Población & Serotipos & $\begin{array}{l}\text { № pacientes } \\
\text { con cólera* }\end{array}$ \\
\hline Wiezba et al & Distrito de Puri, India & Caso control & BivWC & 34 meses & 2 & $\begin{array}{l}\text { Personas no } \\
\text { embarazaras } \\
\text { a partir de } 1 \text { año }\end{array}$ & Ogawa & 35 \\
\hline Ivers et al & $\begin{array}{l}\text { Departamento de Artibonite, } \\
\text { Haiti }\end{array}$ & Caso control & BivWC & 22 meses & 2 & $\begin{array}{l}\text { Personas } \\
\text { a partir de } 1 \text { año }\end{array}$ & $\begin{array}{l}\text { Inaba y } \\
\text { Ogawa }\end{array}$ & 44 \\
\hline Luquero et al & $\begin{array}{c}\text { Distritos de Boffa y Forecariah, } \\
\text { Guinea }\end{array}$ & Caso control & BivWC & 4 meses & 2 & $\begin{array}{l}\text { Personas } \\
\text { mayores de } 1 \text { año }\end{array}$ & Ogawa & $26 \S$ \\
\hline Khatib et al & Zanzibar, Tanzania & Cohorte & WC-rBs & 15 meses & 2 & $\begin{array}{c}\text { Personas no } \\
\text { embarazaras } \\
\text { a partir de } 2 \text { año }\end{array}$ & Ogawa & 39 \\
\hline Lucas et al & Beira, Mozambique & Caso control & WC-rBs & 4 meses & 2 & $\begin{array}{l}\text { Personas no } \\
\text { embarazaras } \\
\text { a partir de } 2 \text { año }\end{array}$ & Ogawa & 39 \\
\hline Azman et al & Juba, Sudán del Sur & Caso control & BivWC & 2 meses & 1 & $\begin{array}{l}\text { Personas a partir de } \\
\quad 1 \text { año }\end{array}$ & Inaba & 34 \\
\hline
\end{tabular}

${ }^{*}$ Número total de pacientes con cólera tanto de los grupos vacunados como de no vacunado. ${ }^{\S}$ Los resultados principales están basados en RDT, no PCR o cultivo, aunque los resultados varían poco según el método de diagnóstico.

Tres de los seis estudios presentaban un riesgo de sesgo de selección bajo y cuatro $(72,88-90)$ tenian un riesgo de sesgo bajo en relación con la comparablilidad de los grupos tanto en el diseño como en el análisis. Ninguno de los estudios de casos y controles reportó las tasas de participación de las participantes para evaluar el riesgo de sesgo. La cohorte y el caso-cohorte tenían un riesgo de sesgos no claro debido al reporte inadecuado de la calidad del seguimiento de la cohorte y las posibles diferencias entre las participantes que se perdieron en el seguimiento con las que quedaron en la cohorte. 
Tabla 5. Resúmen del riesgo de sesgos de los estudios obervacionales

\begin{tabular}{|c|c|c|c|}
\hline $\begin{array}{c}\text { ESTUDIOS DE } \\
\text { CASOS Y CONTROLES }\end{array}$ & $\begin{array}{l}\text { Selección } \\
\text { Max **** }\end{array}$ & $\begin{array}{c}\text { Comparación } \\
\text { Max } * *\end{array}$ & $\begin{array}{l}\text { Exposición } \\
\text { Max } * * *\end{array}$ \\
\hline Lucas et al, 2005 & $* * * *$ & $* *$ & $* *$ \\
\hline Luquero et al, 2012 & $* * * *$ & $* *$ & $*$ \\
\hline Ivers et al, 2015 & $* * * *$ & $* *$ & $* *$ \\
\hline Wiezba et aL, 2015 & $*$ & $*$ & $* *$ \\
\hline
\end{tabular}

\begin{tabular}{|cccc}
\hline $\begin{array}{c}\text { ESTUDIOS DE } \\
\text { COHORTE }\end{array}$ & $\begin{array}{c}\text { Selección } \\
\text { Max } * * *\end{array}$ & $\begin{array}{c}\text { Comparación } \\
\text { Max }\end{array}$ & $\begin{array}{c}\text { Resultado } \\
\text { Max } * * *\end{array}$ \\
\hline Khatib et al, 2012 & $*$ & $*$ & $* *$ \\
Azman et al, 2016 & $* *$ & $* *$ & $* *$ \\
\hline
\end{tabular}

El caso-cohorte de Azman et al fue evaluado como una cohorte puesto que no existen herramientas de evaluación de riesgo de sesgo para estudios caso-cohorte. El máximo de asteriscos (que indica el riesgo mas bajo de sesgo) está indicado al lado de MAX para cada criterio

\subsubsection{Estimaciones con el esquema de dos dosis}

La media de la eficacia vacunal, procedente de los ensayos clínicos $(69,71,78,117,119,122)$, fue del 58\% (95\% CI 42-69, $\left.I^{2}=58 \%\right)$ estudiados para un intervalo de tiempo de entre 4 y 36 meses (28 meses de media ponderada) después de la vacunación. Para los estudios obervacionales $(72,73,88,89,123)$, las estimaciones fueron estudiadas entre 5 y 34 meses después de la vacunación (18 meses de media ponderada). La media de la efectividad vacunal fue del 76\% (62$\left.85, I^{2}=0\right)$. 


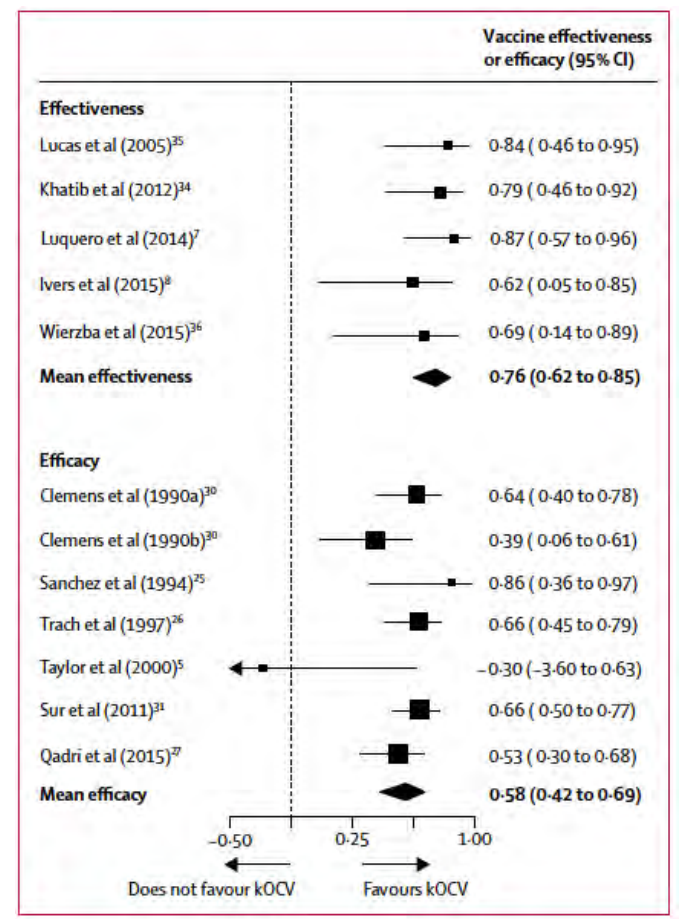

Figura 18. Análisis agrupado principal de efectividad y eficacia de dos dosis de OCV. Tomado de (105)

Los IC al 95\% en la figura (usados en el meta-análisis) están basados en la reconstrucción de unos IC al 95\% bilaterales de las estimaciones del error estándar del estimador para cada estudio, no siendo necesariamentes los mismos que los del artículo original.

Las estimaciones no varían de forma significativa por tipo de vacuna $(p=0 \cdot 53$, BivWC $v s$ WC-rBS) pero si por diseño de estudio $(\mathrm{p}=0.04$, estudio obervacional $v s$ ensayo clínico). Hicimos un análisis de sensibilidad excluyendo los ensayos clínicos que usaban vacunas WC-rBS y encontramos que tanto la eficacia $(57 \cdot 4 \%$, con 28 meses de duración media ponderada) como la efectividad vacunal $(72 \cdot 3 \%$, con 22 meses de duración media ponderada) eran muy parecidas aunque ligeramente menores que las estimadas por los análisis agrupados. No encontramos signos de sesgo de pulicación a partir de la evaluación visual de gráficos en embudo para los estudios observacionales y los ensayos clínicos por separado. 

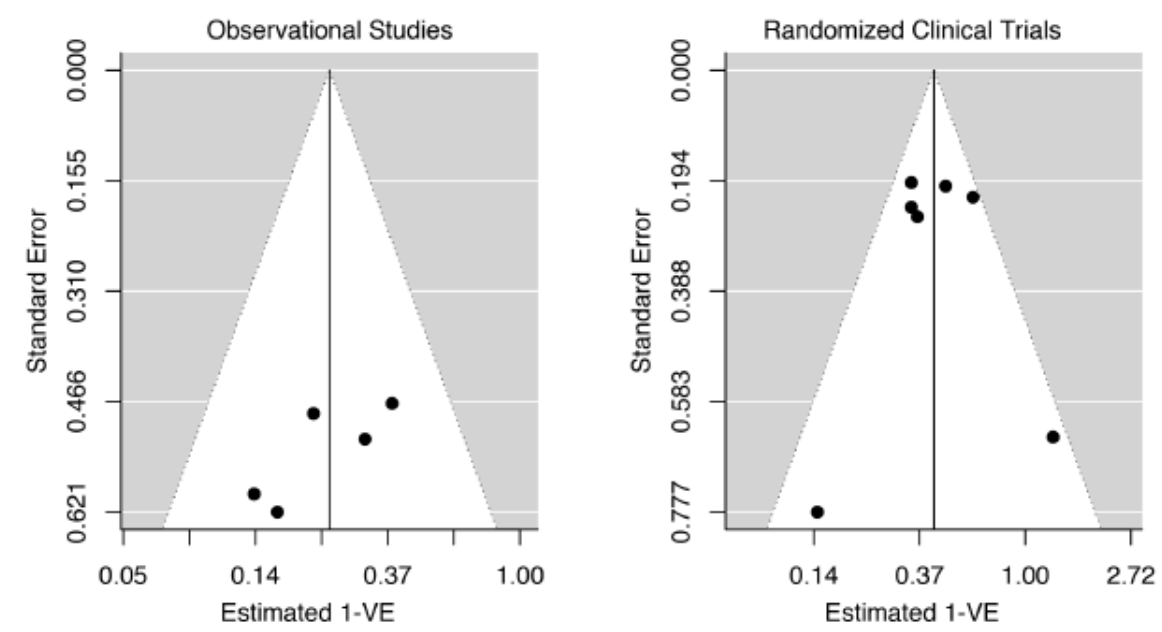

Figura 19. Gráficos en embudo para evaluar el sesgo de publicación. Tomado de (105)

El gráfico de la izquierda representa las estimaciones principales para el régimen de dos dosis a partir de los estudios observacionales y el de la derecha para los ensayos clínicos.

\subsubsection{Estimaciones con el esquema de una dosis}

Solo un estudio de eficacia (92) y otro de efectividad (90) estudiaban el régimen con una dosis como variable principal de estudio. En ambos estudios la protección fue estimada a corto plazo ( 6 y 2 meses respectivamente). Cuatro de los estudios observacionales proporcionan estimadores de protección con una dosis única como variable resultado secundaria $(73,88,89,123)$. Dos estudios que contienen estimadores de eficacia con una dosis (o datos suficientes para estimarlo) no cumplían los criterios de inclusión para la variable evento "cólera confirmado por laboratorio" $(69,124)$.

Dada la escasez de evidencia científica en cuanto a la protección de una dosis de OCV a más largo plazo, y las discusiones globales sobre el uso de una dosis única en brotes, nos centramos en estimar la protección a corto plazo (hasta 1 año después de la vacunación). La efectividad promedio a corto plazo de una dosis de OCV con celulas inactivadas fue del $69 \%$ (IC 95\% 35-85, $\mathrm{I}^{2}=62 \%$ ), esto sólo incluia dos estimadores de efectividad acumulativa que abarcaban más de 1 año $(73,88)$ (ver figura 18D). El único ensayo clínico publicado con una dosis estimó una eficacia a los 6 meses del 40\% (95\% CI 11-60; figura 18B). Las estimaciones no variaban por diseño del estudio ( $\mathrm{p}=0,47 \%$ ensayo clínico vs estudio observacional). La media de 
la efectividad de una dosis a corto plazo (69\% [95\% CI 35-85]; figura 18D) es similar a la de dos dosis (83\% [79-91]; $p=0 \cdot 31$; figura 18C), bien que toda la evidencia viene de poblaciones donde la transmisión de cólera esta presente de forma regular y por tanto con posible inmunidad natural.

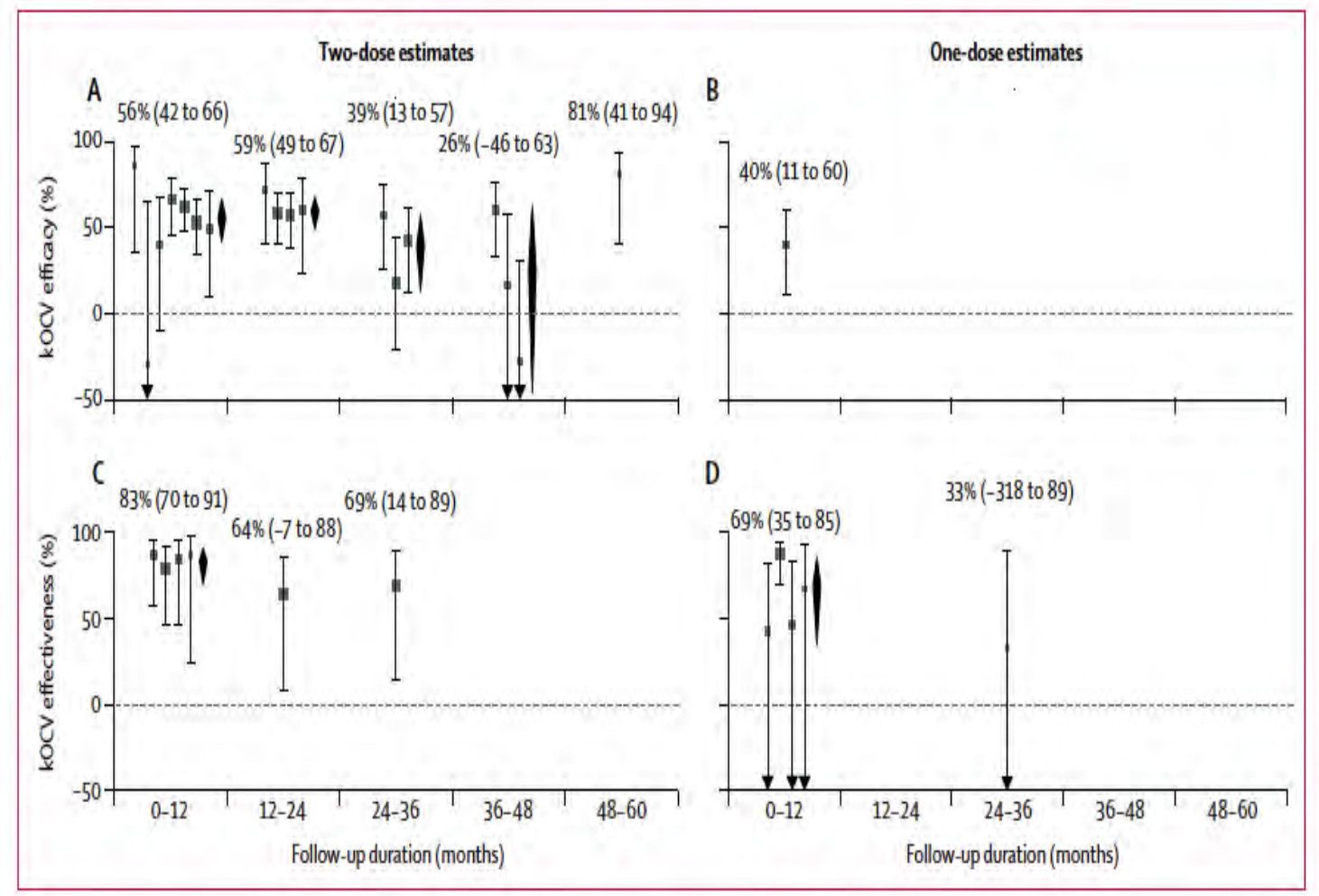

Figura 20. Eficacia y efectividad vacunal por tiempo de seguimiento (desde la vacunación) y número de dosis. Tomado de (105)

Los tiempos de seguimiento se muestran como el punto medio del intervalo de tiempo durante el cual se midió la VE. (A) Estimaciones de eficacia vacunal con dos dosis a los 0-12 meses, 12-24 meses, 24-36 meses y 48-60 meses. (B) Estimaciones de eficacia vacunal con una dosis a los 0-12 meses. (C) Estimaciones de efectividad vacunal con dos dosis a los 0-12 meses, 12-24 meses y 24-36 meses. (D) Estimaciones de efectividad vacunal con dos dosis a los 0-12 meses y 12-24 meses. Las estimaciones se agrupan por período de análisis representando el cero el día de la primera dosis de la vacuna (dosis dependiente). Las barras y cuadrados grises muestran un IC al 95\% y estimaciones de eficacia o efectividad. Los rombos negros muestran la eficacia o efectividad promedio y el IC al 95\%. Los estudios se agruparon por período de tiempo y no todos los estudios cubren el período completo de 12 meses.

\subsubsection{Estimaciones con el esquema de tres dosis}

En dos de los ensayos clínicos se usaron tres dosis de vacuna con una pauta de 6 semanas entre las dosis (tanto con BivWC como con WC-rBS) (66). Al cabo de tres 
años, los resultados del estudio mostraban que la eficacia no era significativamente diferente entre dos y tres dosis (64\% vs 50\%) para el grupo de WC-rBS, pero la eficacia de dos dosis era significativamente menor que la de tres dosis para el grupo de BivWC (39\% vs 52\%) (119). El segundo estudio proporcionaba una tercera dosis de recuerdo 10 meses después del régimen principal de dos dosis y encontraba que la eficacia vacunal dos años después de la primera dosis era del $82 \%$ (IC 95\% 27-95) (71).

\subsubsection{Duración de la protección}

La media de las estimaciones de eficacia vacunal eran similares durante los dos primeros años después de la vacunación, con estimaciones del 56\% (IC 95\% 42$\left.66, I^{2}=45 \%\right)$ en el primer año y del $59 \%\left(49-67, I^{2}=0\right)$ en el segundo año. La eficacia se reducía al 39\% (IC 95\% 13-57, $I^{2}=48 \%$ ) en el tercer año y al 26\% (-46$63, I^{2}=74 \%$ ) en el cuarto año. A partir del cuarto año, los estimadores de eficacia varian altamente entre estudios y el intervalo de confianza de la media de la eficacia pasa por el cero. Sólo un estudio reportó eficacia al quinto año, con una estimación del 81\% (IC 95\% 41-94) (62)

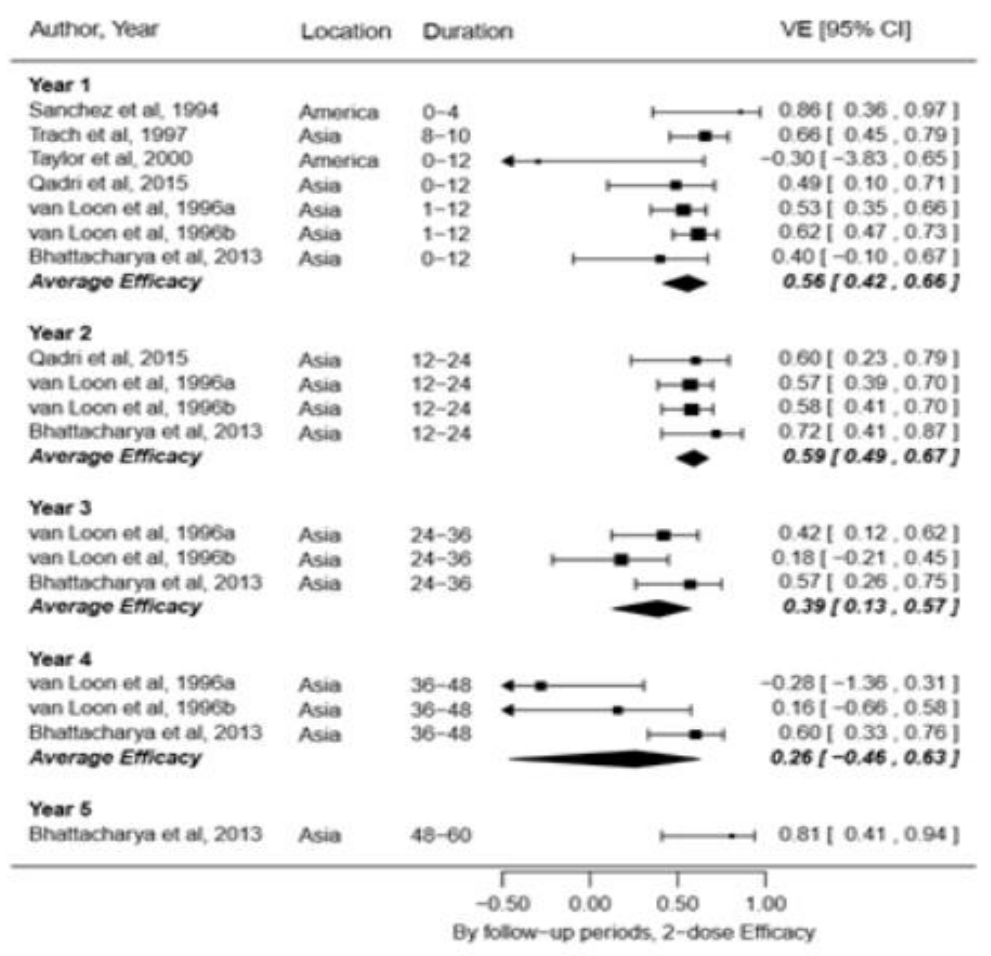

Figura 21. Eficacia con dos dosis por tiempo (en meses) desde la vacunación. (105) 


\subsubsection{Estimaciones por grupo de edad}

En cinco estudios $(69,78,117,119,122)$ tenemos estimaciones por grupos de edad (menores de 5 años, 5-15 años y mayores de 15 años). La media de las estimaciones de eficacia en menores de 5 años fue del 30\% (IC 95\% 15-42; $I^{2}=0 \%$, con una duración media ponderada de la estimación de 31 meses), que es significativamente menor $(\mathrm{p}<0.0001)$ que en los de 5 años y más $(64 \%$; IC 95\% 58-70; $I^{2}=0 \%$, con una duración media ponderada de la estimación de 34 meses), incluyendo estimaciones de eficacia en personas a partir de 15 años de edad. (Ver figura 22)

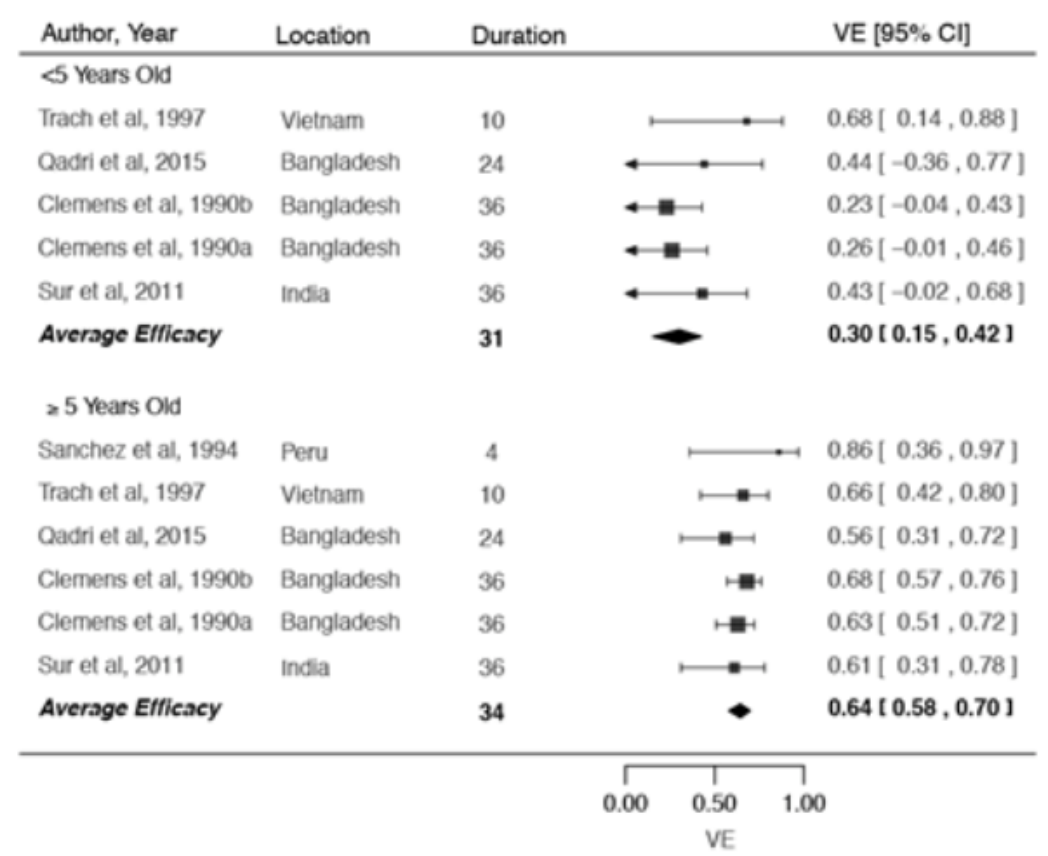

Figura 22. Eficacia por grupo de edad. Tomado de (105)

En algunos de los estudios los datos de mayores de 5 años es a partir de 15 años de edad.

La media de efectividad en menores de 5 años fue del 78\% (IC 95\% 37-96, $I^{2}=0 \%$, con una duración media ponderada de la estimación de 9 meses), siendo similar $(\mathrm{p}=0$-77) a la efectividad en individuos de 5 años y mayores (70\%, IC 44-84; $I^{2}=0 \%$, con una duración media ponderada de la estimación de 14 meses). Sin embargo, la estimación para menores de 5 años viene unicamente de dos estudios que contienen un total de 18 pacientes menores de 5 años $(72,88)$. En menores en edad escolar (5-15 años), la media de la eficacia es del 80\% (IC 95\%41-93), basado en dos ensayos clínicos $(118,122)$. 
Dadas las diferencias en la protección por grupos de edad, investigamos si podiamos explicar la heterogeneidad en las estimaciones de eficacia y efectividad a través de la distribución de la edad de los casos dentro de cada estudio. La mayoria de los estudios no reportaba esta información, con lo que escribimos a los autores para obtenerla, siendo facilitada para 7 de $\operatorname{los} 10$ estudios $(62,66,73,89,90,122,123)$. Encontramos que, en general, a mayor edad de los pacientes mayor era la protección estimada (ver figura 20). El ejemplo más claro lo vemos en el ensayo clinico de 5 años de duración en Calcuta (62), donde un modelo lineal simple predecía un aumento en eficacia de 2 puntos porcentuales (IC $95 \% 0.55-3.4, \mathrm{r}^{2}$ ajustado $=0 \cdot 82$ ) por cada $10 \%$ de incremento en la mediana de edad. Análisis adicionales son necesarios para explorar esta relación entre el aumento de edad y la eficacia, ya que los datos en los estudios (por ejemplo, las estimaciones de un año a otro) están correlacionados y además sólo usamos una muestra de datos que pudimos obtener de los autores del estudio.

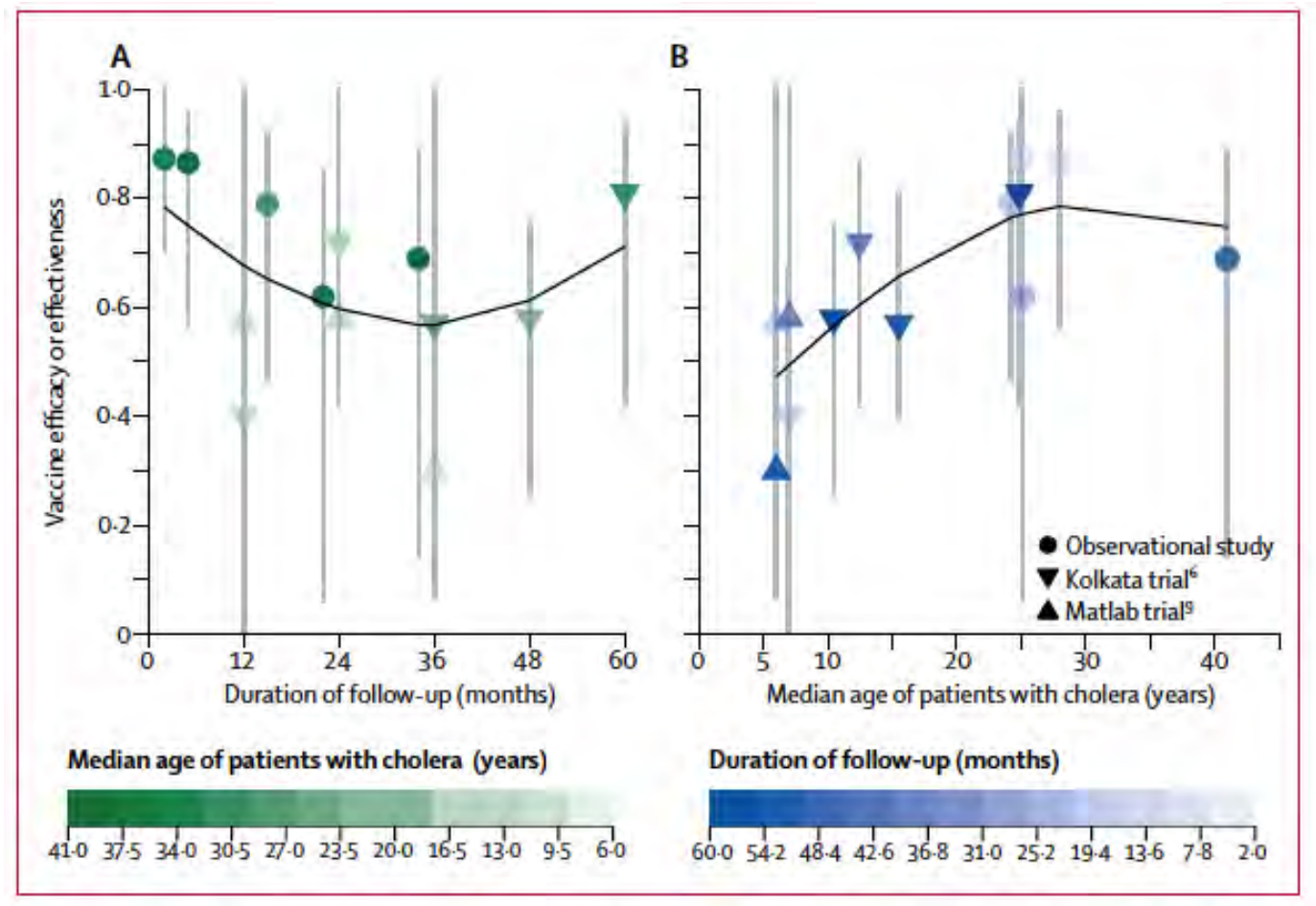

Figura 23. Relación entre la protección vacunal, tiempo de seguimiento y la media de edad de los pacientes con cólera. (A) Relación entre la protección y los meses de seguimiento. Las zonas sombreadas muestran la mediana de edad de los pacientes con cólera. (B) Relación entre la protección y la mediana de edad de los pacientes con cólera en años. Las zonas sombreadas muestran la duración de seguimiento. Las líneas en negro se crearon con una función spline polinomial con tres grados de libertad. Estos gráficos solo incluyen un conjunto de datos donde teníamos la distribución de la edad de los pacientes. Las barras de error son con un IC al 95\%. Tomado de (105) 


\subsection{Descripción del brote de cólera de 2016 en Zambia}

El 4 de febrero de 2016 (semana epidemiológica 5) fue notificado el primer caso de cólera en Kanyama, siendo el primer caso confirmado de cólera en Lusaka desde 2011. Mediante análisis de laboratorio se identificó al Vibrio cholerae 01 El Tor Ogawa como la cepa circulante causante del brote.

En la semana epidemiológica 10 se produjo un fuerte incremento de casos sospechosos (de 14 a 118), la mayoría provenientes de Bauleni (84\%). El mayor número de casos notificados se observó durante la semana epidemiológica 12, con un total de 150 casos sospechosos. El último caso confirmado fue notificado el 30 de mayo de 2016 (semana epidemiológica 22) procedente de Kanyama. La declaración oficial del final del brote fue el 15 de junio de 2016 (semana epidemiológica 24) tras 14 días sin ningún caso confirmado. El número total de casos registrados por el MS al final del brote fue de 1139 casos (sospechosos y confirmados) y de 20 defunciones (10 de ellas en la comunidad). La letalidad fue de $1.76 \%$ entre los casos hospitalizados y de $0.88 \%$ una vez excluidos los que llegaban fallecidos al centro de salud.

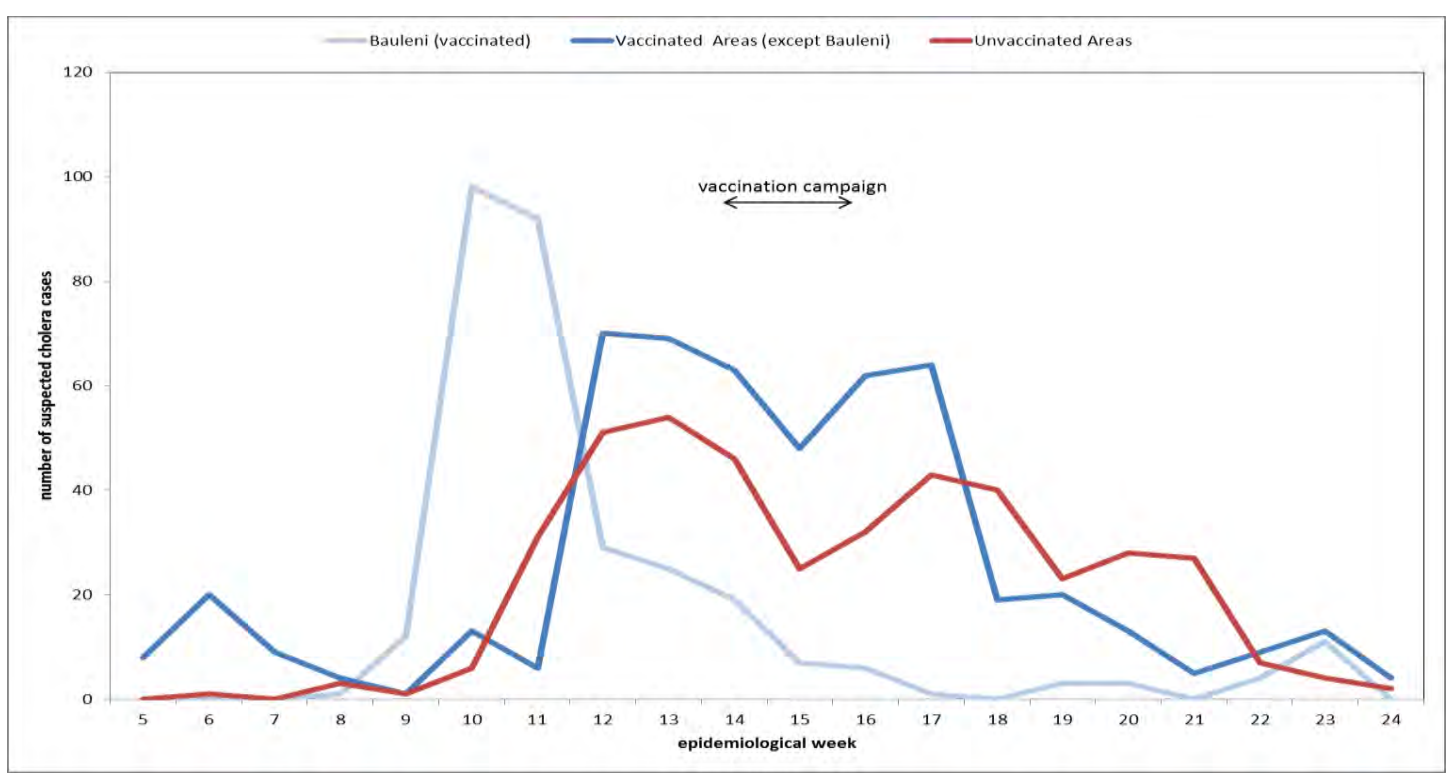

Figura 24. Casos sospechosos de cólera por semana epidemiológica en el municipio de Bauleni ( área vacunada), áreas vacunadas (excluyendo Bauleni) y áreas no vacunadas 
La tasa de ataque total en Lusaka fue de 4,89 por 10.000 habitantes. Éstas fueron significativamente mayores en los menores de 5 años de edad que en los mayores: 5.80 vs 4,71 por 10.000 habitantes (razón de tasas de ataque: 1.23 ; IC 95\%: 1.061.42); y entre los hombres respecto a las mujeres: 5.20 vs 4.59 por 10.000 habitantes (razón de tasas de ataque: 1.13; IC 95\%: 1.01-1.27).(107)

\subsection{Descripción de la campaña de vacunación con vacuna oral frente al cólera de 2016.}

El 24 de marzo el MS envió una demanda al ICG de 598.131 dosis de vacuna frente al cólera de la reserva global para emergencias (125). Entre el 7 y el 8 de abril la OCV Shanchol ${ }^{\mathrm{TM}}$ (Shantha Biotechnics, Hyderabad, India) llegó a Zambia y su uso fue aprobado por situación de emergencia (ya que no estaba previamente registrada en el país).

La campaña de vacunación con una dosis (a partir de ahora lo llamaremos "primera ronda") de OCV empezó, dirigida por el MS con el apoyo de MSF, el 9 de abril de 2016 (semana epidemiológica 14), cuando ya se había alcanzado el pico en Bauleni, y terminó el 23 de abril (semana 16). La elección de las áreas donde iba a implentarse la campaña de vacunación se hizo en función de las zonas con las tasas de ataque más altas durante la epidemia presente y de aquellas históricamente conocidas por ser propensas a padecer cólera. Las áreas seleccionadas fueron por tanto: Bauleni, Kanyama (que incluye John Laing, New Kanyama, Old Kanyama y Kanyama West), George (incluyendo George Soweto) y Chawama (incluyendo John Howard y Misisi-Kuku.

En total se adminisitraron 424.100 dosis resultando en un $73,4 \%$ de cobertura administrativa (107).

Para más información sobre la implementación de la primera ronda consultar articulo "Implementation research: reactive mass vaccination with single-dose oral cholera vaccine, Zambia." Anexo 1: Artículos relacionados. 
La epidemia siguió extendiendose por algunas areas que estaban consideradas de bajo riesgo y que no eran objeto de la campaña de vacunación (ver figura 24) hasta el 15 de junio que fue la declaración oficial del final del brote.

Tabla 6. Cobertura administrativa de la primera ronda de vacunación

\begin{tabular}{lccc}
\hline $\begin{array}{l}\text { Area } \\
\text { Vacunada }\end{array}$ & $\begin{array}{c}\text { Población } \\
\text { diana }\end{array}$ & $\begin{array}{c}\text { Población } \\
\text { vacunada }\end{array}$ & $\begin{array}{c}\text { Cobertura } \\
\text { administrativa }\end{array}$ \\
\hline Bauleni & $\mathbf{2 9 , 2 4 6}$ & $\mathbf{2 5 , 0 2 3}$ & $85.6 \%$ \\
Kanyama & 252,853 & 192,252 & $76,00 \%$ \\
George & 107,152 & 87,768 & $81,90 \%$ \\
Chawama & 188,792 & 118,701 & $62,90 \%$ \\
TOTAL & $\mathbf{5 7 8 , 0 4 3}$ & $\mathbf{4 2 3 , 7 4 4}$ & $\mathbf{7 3 . 3 \%}$ \\
\hline
\end{tabular}

Entre el 16 y 24 de diciembre de 2016, el país condujo la segunda ronda de la campaña de vacunación con el objetivo de incrementar la duración de la protección de la vacuna. La población diana era la que había recibido la primera dosis. En total se administraron 437.143 dosis resultando en una cobertura administrativa global del 80.4\%. (126)

Tabla 7. Cobertura administrativa de la segunda ronda de vacunación

\begin{tabular}{lccc}
\hline $\begin{array}{l}\text { Area } \\
\text { Vacunada }\end{array}$ & $\begin{array}{c}\text { Población } \\
\text { diana* }\end{array}$ & $\begin{array}{c}\text { Población } \\
\text { vacunada }\end{array}$ & $\begin{array}{c}\text { Cobertura } \\
\text { administrativa* }\end{array}$ \\
\hline Bauleni & 24.000 & 26.672 & $111.0 \%$ \\
Kanyama & 192.326 & 193.557 & $100.6 \%$ \\
George & 87.191 & 92.276 & $106.0 \%$ \\
Chawama & 118.031 & 124.635 & $106.0 \%$ \\
TOTAL & 421.548 & 437.140 & $103.7 \%$ \\
\hline
\end{tabular}

*La población diana fue definida por el número de personas vacunadas en cada area durante la primera ronda.

\subsection{Encuesta de cobertura vacunal después de la primera dosis.}

\subsubsection{Descripción de la muestra y cobertura vacunal global}

Seguido a la primera ronda de la campaña de vacunación con OCV, entre el 17 de abril y el 25 de mayo se reclutaron 505 personas procedentes de las áreas vacunadas en Lusaka como parte de una cohorte. La mediana de edad de los 
participantes fue de 20 años (rango intercuartilico: 9-30 años). La participación fue mayor entre los hombres (59\%) que entre las mujeres. La media de habitantes por hogar fue de 5 personas (desviación estándar: 2,3). La tasa de participación fue del $100 \%$.

En total, el 68,5\% (n=346/505; 95\%IC: 64,3-72,5) de la población encuestada reportó haber recibido una dosis de vacuna durante la primera ronda en abril de 2016. De éstos, el 50,9 \% poseía carné de vacunación.

\subsubsection{Cobertura vacunal por municipios}

Por municipios, Bauleni alcanzó una buena cobertura (80,0\%; IC: 64,0-96,0). La buena movilización de la comunidad podría ser explicada por el pequeño tamaño de población de Bauleni y la alta tasa de enfermedad en el momento de la campaña. Para los otros municipios no existe una relación directa entre el tamaño de población y la cobertura estimada ya que, por ejemplo en George, uno de los municipios más poblados, fue uno de los municipios con mejor cobertura $(87,3 \%$; IC 95\%: 79,5-95,1).

Tabla 8. Coberturas vacunales por municipios

\begin{tabular}{lc} 
& $\%(\mathbf{9 5 \% C I})$ \\
\hline Bauleni & $80,0(64,0-96,0)$ \\
Chawama & $69,3(58,8-79,8)$ \\
George & $87,3(79,5-95,1)$ \\
George-Soweto & $72,7(53,7-9,8)$ \\
John-Howard & $50,0(31,1-68,9)$ \\
Jhon Laing & $49,1(35,5-62,6)$ \\
Kanyama West & $59,3(46,0-72,5)$ \\
Misisi-Kuku & $67,2(55,6-78,8)$ \\
New Kanyama & $73,3(57,2-89,4)$ \\
Old Kanyana & $71,3(61,7-80,8)$ \\
\hline
\end{tabular}

De forma inseperada, puesto que cobertura administrativa fue una de las más altas, la cobertura vacunal más baja se observó en John Laing (49.1\%; IC: 35,5-62,6\%.), indicando que la población diana posiblemente no fuera muy precisa. En Chawama la cobertura no fue muy alta $(69,3$; IC: $58,8-79,8)$. Esto podria ser debido a que, a pesar de que se establecieron muchos puestos de vacunación, entre el 19 y 21 de 
abril ocurrieron unos disturbios violentos no relacionados con la actividad de vacunación (127) que interrumpieron la dinámica de la campaña de vacunación durante 2 días.

\subsubsection{Coberturas vacunales por edad y sexo}

Los resultados de la encuesta muestran que la cobertura vacunal fue mayor entre las mujeres que entre los hombres. Un claro desequilibrio está presente entre los participantes de entre 15 y 60 años donde los hombres están en gran medida infravacunados.

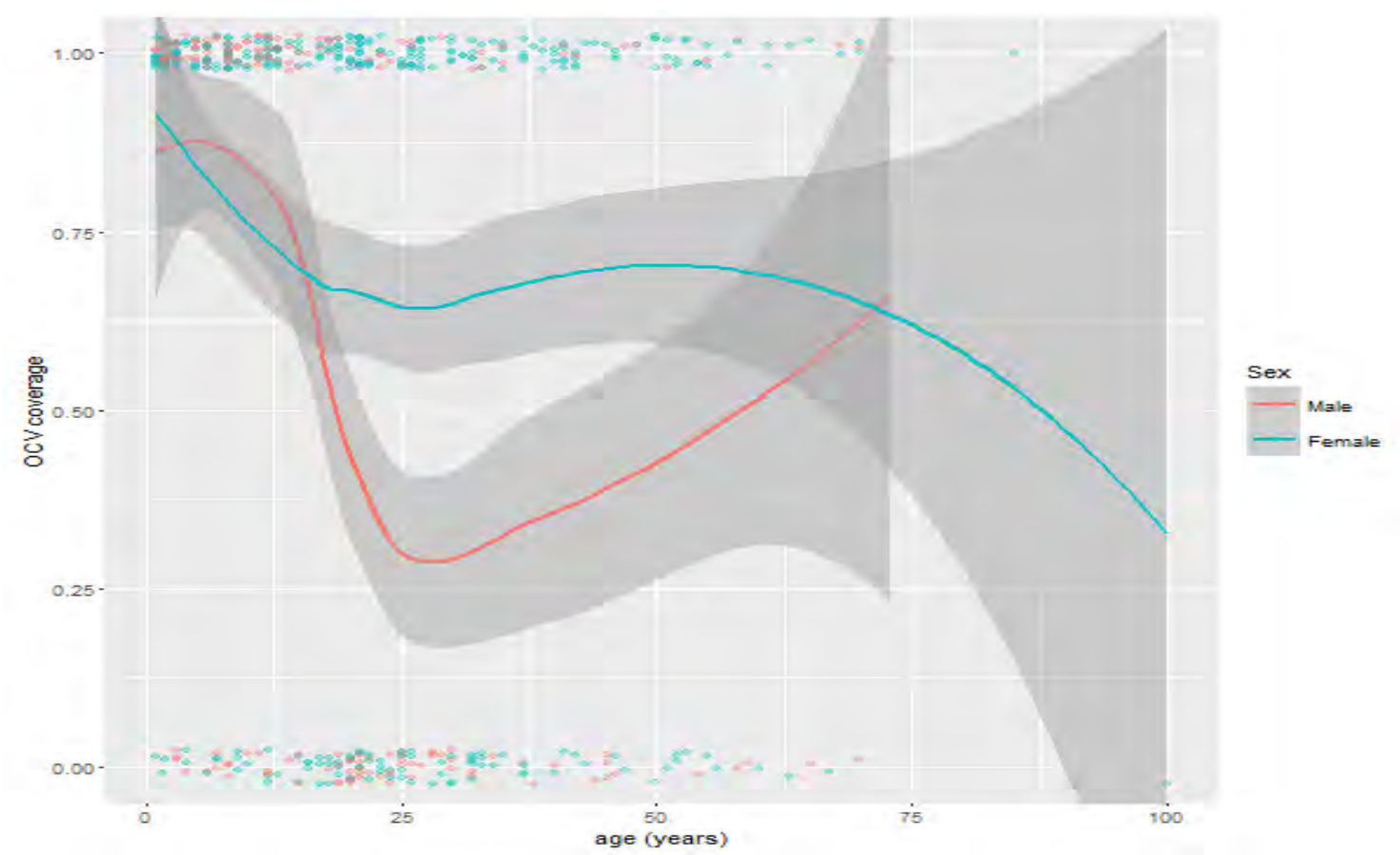

Figura 25. Distribución de la cobertura vacunal por edad y sexo 


\subsection{Evaluación de la efectividad vacunal}

\subsubsection{Características basales de los participantes del estudio.}

Entre el 25 de abril y el 15 de junio de 2016, ingresaron y recibieron tratamiento en los CTC dentro del área del estudio 251 casos sospechosos de cólera, 211 de los cuales se incluyeron en el estudio. Entre el 17 de abril y el 25 de mayo de 2016 reclutamos una cohorte de 921 personas, 505 procedentes de áreas donde fue objeto la campaña de vacunación y 416 de áreas fuera de las zonas objeto de la campaña.

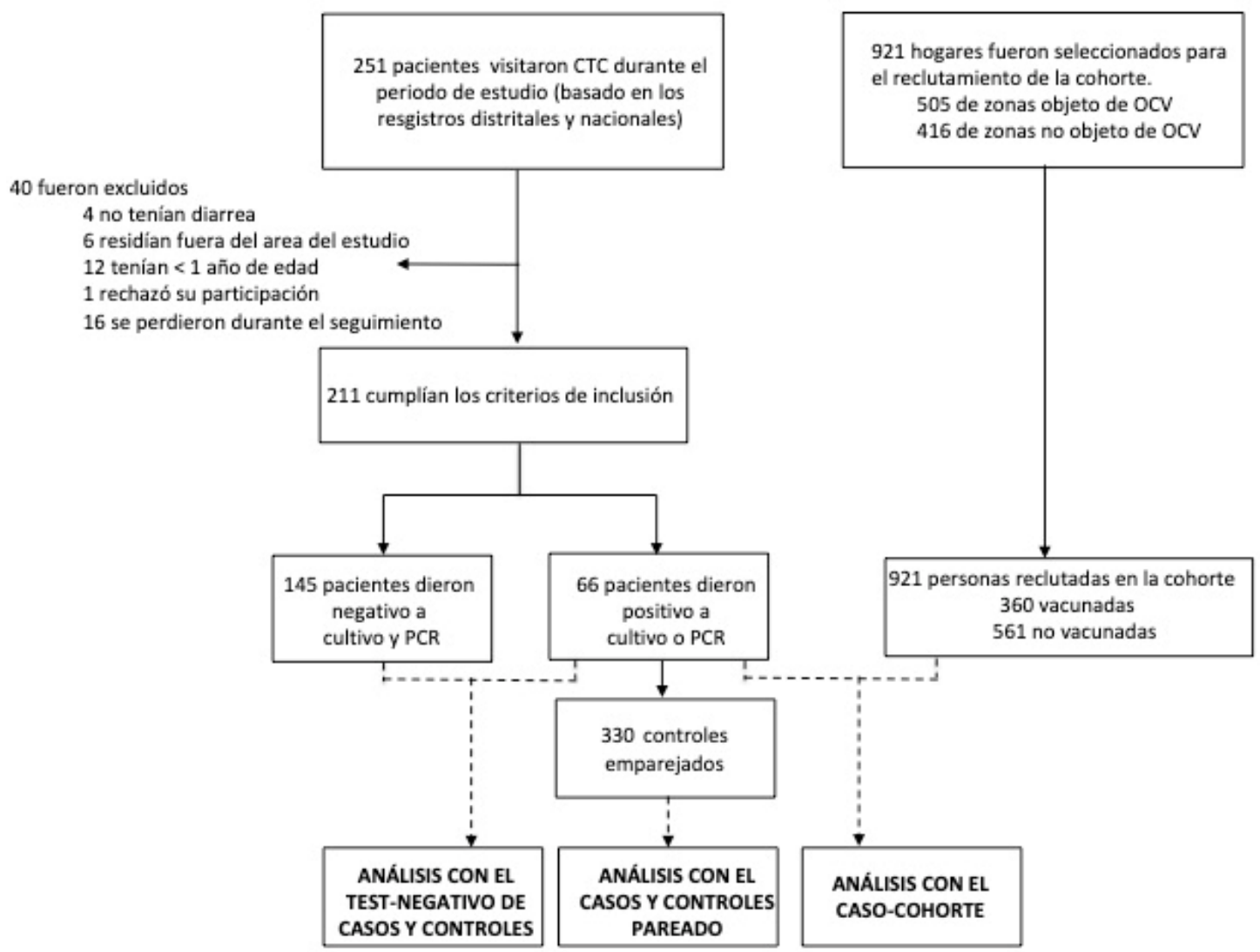

Figura 26. Diagrama de flujo del estudio 


\subsubsection{Descripción de las características de los casos sospechosos y confirmados}

La edad media de los casos sospechosos fue de 21,6 años (desviación estándar: 18,2), siendo el 28\% de los mismos menores de 5 años. La mitad de los casos sopechosos eran mujeres y el $42 \%$ entre los casos confirmados. El $82 \%$ de los casos ingresados presentaban algún grado de deshidratación al ingreso, 55\% con un grado severo y siendo más común entre los casos confirmados que los casos con diarrea no colérica (89\% vs 39\%).

Tabla 9. Presentación clínica y tratamiento de los casos sopechosos de cólera

\begin{tabular}{|lcc|}
\hline & $\begin{array}{c}\text { Casos con } \\
\text { diarrea no colérica } \\
\mathrm{n}=145(\%)\end{array}$ & $\begin{array}{c}\text { Casos con cólera } \\
\mathrm{n}=66(\%)\end{array}$ \\
Edad media (desviación estandar) & $22(19.13)$ & $23(16.16)$ \\
Mujeres & $77(53)$ & $28(42)$ \\
Serotipo & $\mathrm{NA}$ & $66(100)$ \\
Ogawa & $37(25)$ & $0(0)$ \\
Grado de deshidratación en la admisión & $51(35)$ & $7(11)$ \\
A (sin desidratación) & $56(39)$ & $89(90)$ \\
B (leve) & $12(8)$ & $26(40)$ \\
C (severa) & $26(18)$ & \\
\hline Tomaron antibióticos en los 2 días previos a la admisión. & & \\
Tomaron antibióticos antes de la recogida de la muestra & & \\
\hline
\end{tabular}

\subsubsection{Descripción de los casos confirmados y sus controles pareados}

El tamaño de los hogares de los casos confirmados era mayor que de entre aquellos con diarrea no colérica. Los casos confirmados presentaban más a menudo un familiar con cólera en sus hogares la semana anterior y/o en la actualidad, usaban letrinas inundadas con mayor frecuencia y las compartían con más frecuencia con alguien con diarrea respecto los casos sospechosos con diarrea no colérica. Los casos de diarrea no colérica tenían más probabilidad de recibir la OCV que los casos confirmados de cólera. 
Tabla 10. Características de los pacientes con cólera, pacientes con diarrea no colérica y sus controles pareados

\begin{tabular}{|c|c|c|c|c|c|}
\hline & $\begin{array}{l}\text { Casos con } \\
\text { cólera } \\
(n=66)\end{array}$ & Valor $p$ & $\begin{array}{l}\text { Casos con } \\
\text { diarrea no } \\
\text { colérica } \\
(n=145)\end{array}$ & Valor $\mathrm{p}^{* *}$ & $\begin{array}{r}\text { Controles } \\
\text { pareados } \\
\mathbf{n}=330(\%)\end{array}$ \\
\hline Edad media (DS) & $22.7(16.2)$ & 0.545 & $21.1(19.1)$ & 0.93 & $22.6(15.2)$ \\
\hline Mujeres (\%) & $28(42.4)$ & 0.151 & $77(53.1)$ & 1 & $140(42.4)$ \\
\hline $\begin{array}{l}\text { Media del tamaño de los hogares } \\
\text { (DS) }\end{array}$ & $5.8(3.4)$ & 0.113 & $5.2(2.4)$ & 0.89 & $5.9(2.6)$ \\
\hline \multicolumn{6}{|l|}{$\begin{array}{l}\text { Nivel educativo y alfabetización } \\
(\%)\end{array}$} \\
\hline No sabe leer ni escribir & $13(19.7)$ & 1 & $38(26.2)$ & 1 & $52(15.8)$ \\
\hline Sin educación formal & $1(1.5)$ & 0.764 & $2(1.4)$ & 0.72 & $6(1.8)$ \\
\hline Educación primaria & $21(31.8)$ & 0.455 & $45(31.0)$ & 0.42 & $115(34.8)$ \\
\hline Educación secundaria & $31(47.0)$ & 0.144 & $51(35.2)$ & 0.58 & $152(46.1)$ \\
\hline Educación universitaria & $0(0)$ & 0.985 & $9(6.2)$ & 0.98 & $5(1.5)$ \\
\hline $\begin{array}{l}\text { Irían a un centro de salud si } \\
\text { episodio de diarrea }(\%)\end{array}$ & $64(97.0)$ & 0.223 & $144(99.3)$ & 0.11 & $328(99.4)$ \\
\hline $\begin{array}{l}\text { Un habitante del hogar tuvo } \\
\text { cólera la semana anterior ( } \%)\end{array}$ & $20(30.8)$ & $<0.001$ & $9(6.2)$ & $<0.001$ & $9(2.7)$ \\
\hline $\begin{array}{l}\text { Un habitante del hogar tiene } \\
\text { cólera }(\%)\end{array}$ & $13(20.6)$ & $<0.001$ & $5(3.5)$ & $<0.001$ & $6(1.8)$ \\
\hline $\begin{array}{l}\text { Bebe agua de una fuente segura* } \\
(\%)\end{array}$ & $34(53.1)$ & 0.705 & $74(53.2)$ & 0.43 & $153(47.7)$ \\
\hline \multicolumn{6}{|l|}{$\begin{array}{l}\text { Trató el agua la semana previa } \\
\text { (ebullición, cloración, filtración) } \\
(\%)\end{array}$} \\
\hline Nunca & $32(49.2)$ & 1 & $52(36.6)$ & 1 & $123(37.3)$ \\
\hline Alguna vez & $25(38.5)$ & 0.214 & $61(43.0)$ & 0.15 & $146(44.2)$ \\
\hline Siempre & $8(12.3)$ & 0.08 & $29(20.4)$ & 0.11 & $61(18.5)$ \\
\hline $\begin{array}{l}\text { Comparte la fuente de consumo } \\
\text { de agua con alguien con cólera la } \\
\text { semana previa }\end{array}$ & $17(28.8)$ & $<0.001$ & $9(7.4)$ & $<0.001$ & $25(8.3)$ \\
\hline $\begin{array}{l}\text { Comió comida de la calle la } \\
\text { semana previa }(\%)\end{array}$ & $52(80.0)$ & 0.333 & $104(73.8)$ & 0.66 & $252(77.5)$ \\
\hline $\begin{array}{l}\text { Tienen jabón (autorreportado) } \\
(\%)\end{array}$ & $45(69.2)$ & 0.513 & $106(73.6)$ & 0.72 & $221(67.0)$ \\
\hline $\begin{array}{l}\text { Usa un servicio de saneamiento } \\
\text { gestionado de manera segura* } \\
\text { (autorreportado) }(\%)\end{array}$ & $3(4.6)$ & 0.423 & $11(7.6)$ & 0.44 & $24(7.3)$ \\
\hline $\begin{array}{l}\text { La letrina que usa está inundada } \\
\text { (autorreportado) }(\%)\end{array}$ & $8(14.3)$ & 0.047 & $7(5.3)$ & 0.007 & $14(4.5)$ \\
\hline $\begin{array}{l}\text { Comparte la letrina con alguien } \\
\text { con diarrea }(\%)\end{array}$ & $16(25.4)$ & 0.006 & $15(10.6)$ & $<0.001$ & $21(6.5)$ \\
\hline $\begin{array}{l}\text { * según definido por JMP de WHO/ } \\
\text { **Valor p de la regresión univariabl }\end{array}$ & ndicional & tada po & ictores de e & rejamient & actors \\
\hline
\end{tabular}


Los casos confirmados tenían más probabilidad de tener al menos un familiar con cólera la semana anterior a la entrevista, compartir agua de consumo con un paciente con cólera, usar una letrina inundada y compartir la letrina con alguien con diarrea la semana anterior. Ver tabla 10.

\subsubsection{Descripción de las caracteristicas de los participantes de la cohorte}

Existe una sobrerrepresentación de las mujeres en la cohorte. Los participantes de la cohorte tuvieron un comportamiento de menor riesgo en relación al manejo del agua potable que los casos: lo trataban con más frecuencia y usaban agua embotellada o bebían de fuentes de agua potable. Reportaban que compartían agua, hogar o letrina con alguien con diarrea con menor frecuencia que los casos. También reportaban con menor frecuencia tener un vecino con diarrea durante la semana anterior. 
Tabla 11. Características de los participantes de la cohorte y los casos confirmados

\begin{tabular}{|c|c|c|c|}
\hline & $\begin{array}{l}\text { Cohorte } \\
(n=909)\end{array}$ & $\begin{array}{l}\text { Casos } \\
(n=66)\end{array}$ & Valor $p$ \\
\hline Edad media (DS) & $22.9(15.9)$ & $22.7(16.2)$ & 0.916 \\
\hline Mujeres (\%) & 61.2 & 42.4 & 0.003 \\
\hline \multicolumn{4}{|l|}{ Nivel educativo y alfabetización (\%) } \\
\hline No sabe leer ni escribir & 10.8 & 19.7 & 0.094 \\
\hline Sin educación formal & 1.3 & 1.5 & 0.094 \\
\hline Educación formal & 87.9 & 78.8 & 0.094 \\
\hline \multicolumn{4}{|l|}{$\begin{array}{l}\text { Tipo de tratamiento de agua de consumo } \\
\text { (\%) }\end{array}$} \\
\hline Cloración & 63.3 & 85.7 & 0.022 \\
\hline Ebullición & 31.8 & 14.3 & 0.022 \\
\hline Filtración & 5 & 0 & 0.022 \\
\hline $\begin{array}{l}\text { Agua de consumo de una bomba, botella } \\
\text { comercial o grifo (\%) }\end{array}$ & 79.7 & 50.6 & $<0.001$ \\
\hline \multicolumn{4}{|l|}{ Trata el agua (\%) } \\
\hline Nunca & 31.4 & 49.2 & $<0.001$ \\
\hline Alguna vez & 33.3 & 38.3 & $<0.001$ \\
\hline Siempre & 35.3 & 12.6 & $<0.001$ \\
\hline Usa fuente de agua mejorada* (\%) & 79.7 & 50.6 & $<0.001$ \\
\hline $\begin{array}{l}\text { Un vecino tuvo diarrea la semana anterior } \\
\text { (\%) } \\
\text { diarrhea the last week (\%) }\end{array}$ & 6.2 & 25.9 & $<0.001$ \\
\hline $\begin{array}{l}\text { Comparte la fuente de consumo de agua } \\
\text { con alguien con diarrea (\%) }\end{array}$ & 1.3 & 30.1 & $<0.001$ \\
\hline $\begin{array}{l}\text { Comparte la letrina con alguien con diarrea } \\
(\%)\end{array}$ & 2.5 & 25.3 & $<0.001$ \\
\hline $\begin{array}{l}\text { Un habitante del hogar tuvo cólera la } \\
\text { semana anterior (\%) }\end{array}$ & 0.3 & 37.3 & $<0.001$ \\
\hline $\begin{array}{l}\text { Comparte la letrina con alguien con diarrea } \\
\text { o un habitante del hogar tuvo cólera la } \\
\text { semana anterior (\%) }\end{array}$ & 3.8 & 46.5 & $<0.001$ \\
\hline Defeca en un baño dentro de casa (\%) & 17.7 & 4.5 & 0.012 \\
\hline Número de niños menores de 5 años (\%) & $1.7(0.8)$ & $2.06(0.95)$ & 0.001 \\
\hline $\begin{array}{l}\text { Número de niños menores de } 5 \text { años } \\
\text { vacunados de sarampión }\end{array}$ & $1.6(0.7)$ & $2(0.93)$ & $<0.001$ \\
\hline * según definido por JMP de WHO/UNIC & & & \\
\hline
\end{tabular}

\subsubsection{Análisis de eficacia vacunal}

\subsubsection{Análisis con el diseño de casos y controles pareado}

Entre los 211 casos sospechosos de cólera incluidos en el estudio, 66 eran positivos a Vibrio cholerae 01 por cultivo y/o PCR, representando un 31\% del total.

(Ver figura 27) 


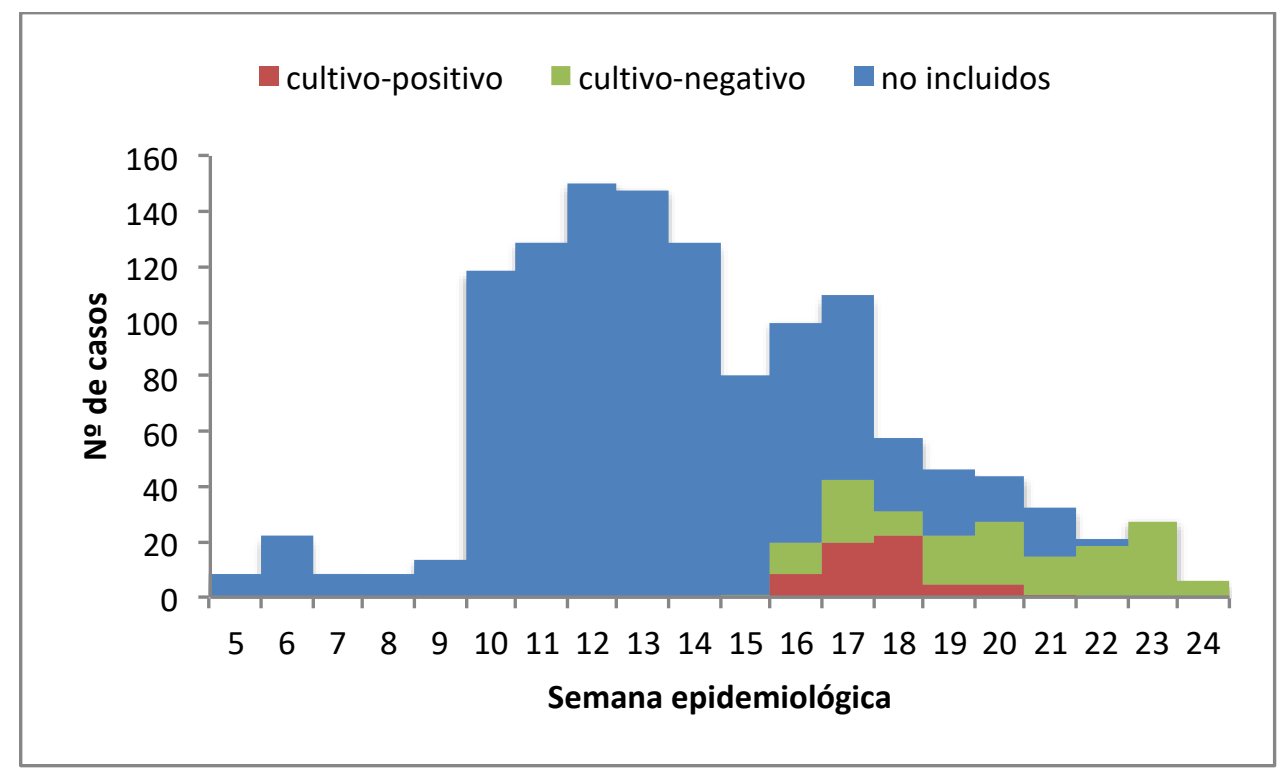

Figura 27. Casos sospechosos en Lusaka en 2016.

Todas las muestras aisladas correspondian a Vibrio cholerae 01 serotipo Ogawa. De ellos, 63 no estaban vacunados mientras que 3 sí lo estaban. En total fueron entrevistados 330 controles apareados de los cuales 44 estaban vacunados. La mediana de la distancia entre la casa de los casos y la de sus respectivos controles era de 49 metros (rango intercuartilico: 16,8-119). Las características de los casos confirmados y de sus controles pareados era similares excepto que los casos reportaban tener familiares que habían padecido cólera recientemente y compartir una fuente de agua de consumo/letrina con alguna persona con cólera/diarrea la semana previa a la entrevista. (Tabla 10)

La vacunación con una dosis de OCV estaba asociada con la protección frente al cólera, tanto en el análisis crudo (EV= 84,7\%; IC 95\%: 27,0-96,6\%) como después de ajustar por potenciales confusores (EV= 88,9\%; IC 95\%: 42,7 -97,8\%) 
Tabla 12. Estimaciones de efectividad vacunal cruda y ajustada

\begin{tabular}{|c|c|c|c|c|c|c|}
\hline & $\begin{array}{l}\text { Vacunados } \\
\text { (una dosis) } † \\
\text { № de partic }\end{array}$ & $\begin{array}{c}\text { No } \\
\text { vacunados } \\
\text { pantes }(\%)\end{array}$ & $\begin{array}{c}\text { Efectividad vacunal } \\
\text { cruda }\end{array}$ & $\begin{array}{c}\text { Valor } \\
\text { p }\end{array}$ & $\begin{array}{c}\text { Efectividad vacunal } \\
\text { ajustada } \\
\text { (IC 95\%) }\end{array}$ & $\begin{array}{c}\text { Valor } \\
\text { p }\end{array}$ \\
\hline \multicolumn{7}{|l|}{$\begin{array}{l}\text { Test-negativo de casos y } \\
\text { controles }\end{array}$} \\
\hline Casos de cólera & $3(5)$ & $63(95)$ & Ref & & Ref & \\
\hline Casos diarrea no colérica & $39(27)$ & $106(73)$ & $87,1 \%(62,4-97,0)$ & $<0.01$ & $* 80,2 \%(16,9-95,3)$ & 0,03 \\
\hline \multicolumn{7}{|l|}{ Casos y controles pareado } \\
\hline Casos de cólera & $3(5)$ & $63(95)$ & Ref & & Ref & \\
\hline Controles pareados & $44(13)$ & $286(87)$ & $84,7 \%(27-96,6)$ & 0,02 & $* * 88,9 \%(42,7-97,8)$ & $<0,01$ \\
\hline \multicolumn{7}{|l|}{ Caso-cohorte } \\
\hline Casos de cólera & $3(5)$ & $63(95)$ & Ref & & Ref & \\
\hline $\begin{array}{l}\text { Persona-tiempo a riesgo } \\
\text { (días)) }\end{array}$ & $48.765,6$ & 1.8826 & $86,7 \%(56,6-95,9)$ & $<0,01$ & $+89,4 \%(64,6-96,9)$ & $<0,01$ \\
\hline
\end{tabular}

*TNCC: Efectividad vacunal ajustada por edad, nivel educativo, frecuencia de tratamiento del agua de consumo y contacto (variable combinada que considera como "expuesto"aquellos con un familiar en el hogar con cólera en la semana previa o que compartían el agua de consumo con un paciente con cólera). Vivir en un area seleccionada por la campaña de vacunación se incluyó como una variable de estratificación en el modelo de regresión logística condicional.

**MCC: Ajustada por contacto. Vivir en un area seleccionada por la campaña de vacunación se incluyo como una variable de estratificación en el modelo de regresión

†CC: Efectividad vacunal ajustada por edad, sexo, número de menores de 5 años de edad viviendo en el hogar, acceso a agua potable y lugar de defecación.

\subsubsection{Análisis con el diseño de test-negativo de casos y controles}

De los 145 casos con diarrea no colérica, 39 estaban vacunados y 106 no lo estaban. Aplicando modelos de regresión logistica, la EV fue del 87,1\% (IC 95\%: $62,4-97,0 \%$ ) y $80,2 \%$ (IC 95\%: 16,9-95,3) respectivamente. (Tabla 12)

\subsubsection{Análisis con el diseño de caso-cohorte}

En conjunto, reclutamos 360 personas vacunadas y 561 no vacunadas como parte de la cohorte con un $100 \%$ de aceptación de participación. De éstos, conseguimos recontactar durante el seguimiento con 811 (un $88 \%$ del total de participantes). En la cohorte se reportaron 28 casos con diarrea acuosa aguda, pero ninguno de ellos ingresó en un centro de salud y ninguno apareció en los registros de los CTC. A 
través del sistema de vigilancia pasivo se reclutaron 66 casos confirmados (los mismos que para el MCC y el TNCC). La EV cruda usando el diseño de caso-cohorte fue del 86,7\% (IC 95\%: 86,6-95,9\%) y la ajustada del 89,4\% (IC 95\%: 64,6 -96,9\%) (Tabla 12).

\subsubsection{Análisis estratrificado por edad, severidad y área seleccionada para la campaña de vacunación.}

Realizamos una serie de análisis estratificados para comprender cómo las estimaciones de efectividad vacunal podrían variar según la edad, la severidad de la enfermedad (determinada por el grado de deshidratación) y el área geográfica. Los niveles de protección estimados (ver Tabla 13) son similares a los presentados en los análisis principales cuando restringimos los análisis para incluir:

- Sólo a los mayores de 5 años

- Sólo a los casos con deshidratación o

- Sólo aquellos que residen en áreas seleccionadas para la vacunación

Tabla 13. Análisis estratificados por edad, severidad de la enfermedad y área seleccionada por la campaña para la vacunación

\begin{tabular}{|c|c|c|c|c|c|c|c|}
\hline & Controles & & Casos & & VE & IC 95\% & Valor $p$ \\
\hline & $\mathrm{N}$ & (\%) & $\mathrm{N}$ & (\%) & $\%$ & & \\
\hline \multicolumn{8}{|c|}{ Personas a partir de 5 años* } \\
\hline No vacunados & 231 & $(84.0)$ & 52 & $(94.5)$ & Ref & & \\
\hline Vacunados & 44 & $(16.0)$ & 3 & (5.5) & $84.3 \%$ & $(27.0-96.6)$ & 0.018 \\
\hline \multicolumn{8}{|c|}{ Casos con deshidratación severa† } \\
\hline No vacunados & 253 & $(87.2)$ & 57 & $(96.6)$ & Ref & & \\
\hline Vacunados & 37 & $(12.8)$ & 2 & (3.4) & $90.4 \%$ & $(22.7-98.8)$ & 0.028 \\
\hline \multicolumn{8}{|c|}{$\begin{array}{l}\text { Personas que residen en areas } \\
\text { seleccionadas para vacunación }\end{array}$} \\
\hline No vacunados & 62 & $(59.6)$ & 18 & $(85.7)$ & Ref & & \\
\hline Vacunados & 42 & (40.4) & 3 & (14.3) & $84.0 \%$ & $(25.2-96.6)$ & 0.020 \\
\hline
\end{tabular}

* Sólo había 11 menores de 5 años con cólera confirmado (Ninguno de los casos ni dessus controles estaban vacunados) † Solo había 7 casos con cólera confirmado (1 vacunado y 6 no vacunados; 6 pares discordantes en total).

No teníamos suficientes casos menores de cinco años, ni con deshidratación de leve a moderada para obtener estimaciones estables de la protección conferida por la OCV en estas subpoblaciones tan importantes. 


\subsubsection{Análisis de indicador de sesgo}

El análisis de indicador de sesgo incluyó 145 personas con diarrea no colérica y 227 controles apareados. En este análisis encontramos que el odds del estado vacunal no variaba de forma significativa entre los dos grupos tanto en el análisis crudo como en el ajustado ( $\mathrm{p}=0.29$ en el análisis ajustado), con lo que sugiere ausencia de sesgo de selección.

Tabla 14. Análisis de indicador de sesgo

\begin{tabular}{|c|c|c|c|c|c|c|}
\hline \multirow[t]{2}{*}{ Estado vacunal } & Controles & Casos & $\begin{array}{l}\text { Eficacia vacunal } \\
\text { cruda }\end{array}$ & Valor $p$ & $\begin{array}{c}\text { Eficacia vacunal } \\
\text { ajustada* }\end{array}$ & Valor $p$ \\
\hline & \multicolumn{2}{|c|}{ no de pacientes(\%) } & $95 \%$ & & $95 \%$ & \\
\hline No vacunado & 499 (69) & $106(73)$ & Referencia & & Referencia & \\
\hline Vacunado & $226(31)$ & $39(27)$ & $22.8 \%(-19.7-57.5 .0)$ & 0.200 & $24.6 \%(-27.5-55.5)$ & 0.292 \\
\hline
\end{tabular}

*EV ajustada por frecuencia de tratamiento del agua de consumo y disponibilidad de jabón en casa. Vivir en un área seleccionada por la campaña de vacunación fue incluida como variable de estratificación en el modelo de regresión logística condicional

Por tanto, podemos concluir que no había una asociación significativa entre el estado vacunal y la diarrea no colérica, indicando una baja probabilidad de que las estimaciones de efectividad vacunal primarias hayan sido debidas en gran medida al sesgo de comportamiento de búsqueda de atención sanitaria.

\subsubsection{Factores de confusión y de modificación de efecto: Selección del modelo para el estimador ajustado.}

Exploramos el posible efecto confusor de factores de riesgo que son bien conocidos para la infección por cólera (Tablas 10 y 11) para así poder obtener estimaciones ajustadas (Tabla 12).

\subsubsection{Diseño de casos y controles pareado}

Este análisis identificó, para el diseño de MCC, una única variable con un efecto potencial de confusión en la relación entre la ingesta de la vacuna y el estado de caso: "compartir la fuente de agua potable con un paciente de cólera durante la semana anterior ". Esta variable tenía valores de p inferiores a 0,2 tanto en comparación con el evento de interés $(p<0,001)$ como con la exposición $(p=0,15)$ (Ver Tablas 9 y 11). Por otro lado, reproducimos modelos de regresión logística 
condicional incluyendo la condición de caso/control como variable dependiente, el estado vacunal como la exposición principal y cada factor potencial de confusión para identificar las variables que modificaran la estimación de efectividad vacunal cruda más del 5\%. Desarrollamos así un modelo para cada variable incluidas en la Tabla 10 y siguiendo este procedimiento identificamos como posible confusor otra variable: "Familiar en el hogar con cólera durante la semana anterior". Esta variable modificaba la efectividad vacunal cruda del $85 \%$ al $92 \%$.

Tabla 15. Características de los vacunados y los no vacunados según el diseño

\begin{tabular}{|c|c|c|c|c|c|c|}
\hline & \multicolumn{3}{|c|}{ TNCC } & \multicolumn{3}{|c|}{ MCC } \\
\hline & $\begin{array}{l}\text { No } \\
\text { vacunados } \\
(n=169)(\%)\end{array}$ & $\begin{array}{l}\text { Vacunados } \\
(n=42)(\%)\end{array}$ & Valor $p$ & $\begin{array}{l}\text { No } \\
\text { vacunados } \\
(n=349)(\%)\end{array}$ & $\begin{array}{l}\text { Vacunados } \\
(n=47)(\%)\end{array}$ & Valor $p$ \\
\hline Media de edad (DS) & $24.35(18.40)$ & $10.55(12.58)$ & $<0.001$ & $22.5(1558.97)$ & $23.26(1330.16)$ & 0.749 \\
\hline Mujeres (\%) & $81(47.93)$ & $24(57.14)$ & 0.287 & $146(41.83)$ & $22(46.81)$ & 0.518 \\
\hline $\begin{array}{l}\text { Media del tamaño de los hogares } \\
\text { (DS) }\end{array}$ & $5.38(287.41)$ & $5.36(241.76)$ & 0.967 & $5.88(273.36)$ & $5.85(316.9)$ & 0.948 \\
\hline \multicolumn{7}{|l|}{$\begin{array}{l}\text { Nivel educativo y alfabetización } \\
(\%)\end{array}$} \\
\hline No sabe leer ni escribir & 30 (17.75) & $21(50)$ & 1 & $62(17.77)$ & $3(6.38)$ & 1 \\
\hline Sin educación formal & $3(1.78)$ & $0(0)$ & 0.986 & $6(1.72)$ & $1(2.13)$ & 0.315 \\
\hline Educación primaria & $54(31.95)$ & $12(28.57)$ & 0.007 & $120(34.38)$ & $16(34.04)$ & 0.118 \\
\hline Educación secundaria & $74(43.79)$ & $8(19.05)$ & $<0.001$ & $156(44.7)$ & $27(57.45)$ & 0.042 \\
\hline Educación universitaria & $8(4.73)$ & $1(2.38)$ & 0.117 & $5(1.43)$ & $0(0)$ & 0.99 \\
\hline $\begin{array}{l}\text { Irían a un centro de salud si } \\
\text { presentara diarrea }(\%)\end{array}$ & $166(98.22)$ & $42(100)$ & 0.987 & $345(98.85)$ & $47(100)$ & 0.985 \\
\hline $\begin{array}{l}\text { Un habitante del hogar tuvo } \\
\text { cólera la semana anterior }(\%)\end{array}$ & $26(15.57)$ & $3(7.14)$ & 0.186 & $25(7.23)$ & $4(8.51)$ & 0.773 \\
\hline $\begin{array}{l}\text { Un habitante del hogar tiene } \\
\text { cólera }(\%)\end{array}$ & $15(9.2)$ & $3(7.32)$ & 0.704 & $16(4.62)$ & $3(6.38)$ & 0.6 \\
\hline $\begin{array}{l}\text { Bebe agua de una fuente segura* } \\
(\%)\end{array}$ & $87(54.04)$ & $21(50)$ & 0.724 & $169(50)$ & $18(38.3)$ & 0.202 \\
\hline \multicolumn{7}{|l|}{$\begin{array}{l}\text { Trató el agua la semana previa } \\
\text { (ebullición, cloración, filtración) } \\
(\%)\end{array}$} \\
\hline Nunca & $74(44.85)$ & $10(23.81)$ & 1 & $136(39.08)$ & $19(40.43)$ & 1 \\
\hline Alguna vez & $67(40.61)$ & $19(45.24)$ & 0.082 & $150(43.1)$ & $21(44.68)$ & 0.995 \\
\hline Siempre & $24(14.55)$ & $13(30.95)$ & 0.004 & $62(17.82)$ & $7(14.89)$ & 0.649 \\
\hline $\begin{array}{l}\text { Comparte la fuente de consumo } \\
\text { de agua con alguien con cólera la } \\
\text { semana previa }\end{array}$ & $22(15.6)$ & $4(10.26)$ & 0.404 & $40(12.62)$ & $2(4.76)$ & 0.154 \\
\hline $\begin{array}{l}\text { Comió comida de la calle la } \\
\text { semana previa }(\%)\end{array}$ & $122(74.39)$ & $34(80.95)$ & 0.378 & $267(77.62)$ & $37(80.43)$ & 0.665 \\
\hline Tiene jabón ( autorreportado) (\%) & $127(76.05)$ & $24(57.14)$ & 0.016 & $233(66.95)$ & $33(70.21)$ & 0.655 \\
\hline $\begin{array}{l}\text { Usa servicios de saneamiento } \\
\text { gestionado de forma segura* } \\
\text { (autorreportado) (\%) }\end{array}$ & $13(7.78)$ & $1(2.38)$ & 0.238 & $25(7.18)$ & $2(4.26)$ & 0.461 \\
\hline $\begin{array}{l}\text { la letrina que usa está inundada } \\
\text { (autorreportado) (\%) }\end{array}$ & $11(7.33)$ & $4(10.81)$ & 0.488 & $22(6.67)$ & $0(0)$ & 0.985 \\
\hline $\begin{array}{l}\text { Comparte la letrina con alguien } \\
\text { con diarrea }(\%)\end{array}$ & $26(16.05)$ & $5(11.9)$ & 0.384 & $33(9.62)$ & $4(8.89)$ & 0.885 \\
\hline \multicolumn{7}{|c|}{ * según definido por JMP de WHO/UNICEF } \\
\hline
\end{tabular}


Probablemente estos dos posibles factores de confusión identificados miden una dimensión similar del riesgo de contraer cólera, así como se refleja en la prueba exacta de Fisher al explorar la asociación entre estas dos variables en todos los participantes ( $\mathrm{p}<0.001)$. Por tanto, decidimos combinar ambas variables en una sola variable llamada "contacto" que considera como expuestos a aquellos que tuvieron un familiar en el hogar con cólera en la semana anterior o que compartieron la fuente de agua de consumo con un paciente con cólera. El modelo ajustado final incluye esta variable combinada como un posible factor de confusión. Además, considerando que los casos en el análisis principal podrían venir tanto de áreas seleccionadas como no seleccionadas por la campaña de vacunación, y que por tanto tenían probablemente una línea de base diferente de riesgo de cólera, decidimos incluir en el modelo de regresión logística condicional la variable binaria "área vacunada" como estratificación

\subsubsection{Diseño de test-negativo de casos y controles}

Para el TNCC, durante el proceso de análisis bivariable con factores de riesgo bien conocidos de infección por cólera, las variables asociadas $(p<0,2)$ tanto con el evento de interés (cólera confirmado) como con la exposición (vacunación con OCV) fueron:, "educación", " al menos un familiar en el hogar con cólera en la semana anterior "y" frecuencia de tratamiento del agua" (ver Tablas 9 y 10). El modelo ajustado final incluye la variable "edad" ya que puede ser un factor de confusión asociado tanto con la cobertura vacunal como con la EV. Además incluimos la variable combinada "contacto" como un posible factor de confusión y estratificamos por "área vacunada" por las razones expuestas anteriormente.

\subsubsection{Diseño de caso-cohorte}

En el caso-cohorte, además del estado vacunal, incluimos el sexo en cada modelo multivariado debido a la sobrerrepresentación de las mujeres en la cohorte. Una parte importante de los participantes de la cohorte fue reclutada después de la inclusión de la mayor parte de los casos, en un período donde estaba disminuyendo bruscamente la incidencia del brote. Por tanto, consideramos y excluimos del análisis multivariado las variables evaluadoras de los contactos 
directos o indirectos con alguien con diarrea (compartir letrina, agua de cosnumo, hogar o asistir al funeral de alguien con cólera) para evitar artefactos que sobreestimaran el RR y por tanto sesgaran las estimaciones de EV. 
RESULTADOS |109

Tabla 16. Características de los vacunados y no vacunados en el diseño de caso-cohorte

\begin{tabular}{|c|c|c|c|c|}
\hline & $\begin{array}{l}\text { No vacunados } \\
(n=614)\end{array}$ & $\begin{array}{l}\text { Vacunados } \\
(n=361)\end{array}$ & $\begin{array}{l}\text { Valor } \\
\text { p }\end{array}$ & $\begin{array}{c}\text { Variación de } \\
\text { la VE } \\
\text { (\%) }\end{array}$ \\
\hline Edad (sd) & $24.5(15.3)$ & $20.2(16.6)$ & 0 & $-1.10 \%$ \\
\hline Sexo femenino (\%) & 56.5 & 65.9 & 0.004 & $5.80 \%$ \\
\hline \multicolumn{5}{|l|}{ Educación (\%) } \\
\hline Analfabeto & 8.5 & 16.3 & 0.001 & $-7.60 \%$ \\
\hline Educación no formal & 1.1 & 1.7 & 0.001 & $-7.60 \%$ \\
\hline Educación formal & 90.3 & 82 & 0.001 & $-7.60 \%$ \\
\hline \multicolumn{5}{|l|}{ Tipo de tratamiento de aguas (\%) } \\
\hline Cloración & 59.7 & 74.2 & 0.001 & $-16.40 \%$ \\
\hline Ebullición & 33.6 & 25 & 0.001 & $-16.40 \%$ \\
\hline Filtración & 6.7 & 0.8 & 0.001 & $-16.40 \%$ \\
\hline $\begin{array}{l}\text { Agua de consumo de una bomba, } \\
\text { embotellada o grifo (\%) }\end{array}$ & 77.6 & 78.1 & 0.88 & $0.00 \%$ \\
\hline \multicolumn{5}{|l|}{ Tratamiento agua de consumo (\%) } \\
\hline Nunca & 33.8 & 30.8 & 0.432 & $2.00 \%$ \\
\hline A veces & 32.9 & 34.7 & 0.432 & $2.00 \%$ \\
\hline Siempre & 33.3 & 34.5 & 0.432 & $2.00 \%$ \\
\hline Usa fuente de agua potable* (\%) & 77.6 & 78.1 & 0.88 & $0.00 \%$ \\
\hline $\begin{array}{l}\text { Vecino con diarrea semana } \\
\text { anterior }(\%)\end{array}$ & 8.6 & 5.7 & 0.122 & $7.70 \%$ \\
\hline $\begin{array}{l}\text { Comparte agua con alguien } \\
\text { con diarrea }(\%)\end{array}$ & 4.3 & 1.5 & 0.052 & $16.60 \%$ \\
\hline $\begin{array}{l}\text { Comparte letrina con alguien } \\
\text { con diarrea }(\%)\end{array}$ & 5.3 & 2 & 0.041 & $19.10 \%$ \\
\hline $\begin{array}{l}\text { Cólera en el hogar semana pasada } \\
(\%)\end{array}$ & 3.5 & 1.7 & 0.104 & $3.20 \%$ \\
\hline $\begin{array}{l}\text { Comparte agua o letrina con } \\
\text { alguien con diarrea o cólera en el } \\
\text { hogar semana anterior }(\%)\end{array}$ & 8.4 & 3.8 & 0.021 & $37.10 \%$ \\
\hline $\begin{array}{l}\text { Defeca en baño dentro del hogar } \\
(\%)\end{array}$ & 23.5 & 5.5 & 0 & $-14.70 \%$ \\
\hline Número de menores de 5 años (\%) & $1.7(0.81)$ & $1.8(0.8)$ & 0.173 & $-2.10 \%$ \\
\hline $\begin{array}{l}\text { Número de menores de } 5 \text { años } \\
\text { vacunados contra sarmpión (\%) }\end{array}$ & $1.6(0.78)$ & $1.7(0.7)$ & 0.052 & $-6.80 \%$ \\
\hline
\end{tabular}

*definido por el JMP de la OMS/UNICEF 
Las variables relacionadas con la gestión del agua, que diferían entre los casos y la cohorte, se correlacionaron entre sí, por lo que sólo consideramos la variable más global utilizando la definición internacional de acceso al agua potable del Programa de Monitoreo Conjunto de la OMS/UNICEF. La misma lógica fue aplicada a las variables que evalúan el uso de letrinas/defecación.

Finalmente, el criterio de información de Akaike (AIC) y el criterio de información bayesiano (BIC) acuerdan y privilegian un modelo final sin variables evaluadoras del nivel de educación.

En síntesis, en la siguiente Tabla 17 mostramos un resumen de las variables incluidas en los modelos multivariados.

Tabla 17. Resúmen de las varibales incluidas en los modelos multivariados

\begin{tabular}{|c|c|c|c|}
\hline & TNCC & MCC & CC \\
\hline Efectividad vacunal cruda (1C95\%) & $\begin{array}{c}87.1 \% \\
(62.4-97.0)\end{array}$ & $\begin{array}{c}84.7 \% \\
(27.0-96.6)\end{array}$ & $\begin{array}{c}86.7 \% \\
(56.6-95.9)\end{array}$ \\
\hline $\begin{array}{l}\text { Variables incluidas como posibles } \\
\text { confusores }\end{array}$ & & & \\
\hline Edad & $\mathrm{x}$ & & $\mathrm{x}$ \\
\hline Sexo & & & $\mathrm{x}$ \\
\hline Nivel educativo & $\mathrm{x}$ & & \\
\hline $\begin{array}{l}\text { Frequencia de tratamiento de agua de } \\
\text { consumo }\end{array}$ & $\mathrm{x}$ & & \\
\hline $\begin{array}{l}\text { Familiar del hogar con cólera semana } \\
\text { anterior }\end{array}$ & $\mathrm{x}$ & $\mathrm{x}$ & \\
\hline $\begin{array}{l}\text { Compartió fuente de agua de consumo con } \\
\text { un paciente de cólera }\end{array}$ & $\mathrm{x}$ & $\mathrm{x}$ & \\
\hline $\begin{array}{l}\text { Número de menores de } 5 \text { años viviendo en } \\
\text { el hogar }\end{array}$ & & & $\mathrm{x}$ \\
\hline Acceso agua potable & & & $\mathrm{x}$ \\
\hline Lugar de defecación & & & $\mathrm{x}$ \\
\hline Efectividad vacunal ajustada (IC95\%) & $\begin{array}{c}80.2 \% \\
(16.9-95.3)\end{array}$ & $\begin{array}{c}88.9 \% \\
(42.7-97.8)\end{array}$ & $\begin{array}{c}89.4 \% \\
(64.6-96.9)\end{array}$ \\
\hline
\end{tabular}




\subsubsection{Valores faltantes}

Las bases de datos, tanto para el caso control como para la cohorte, no contienen ningún valor faltante tanto para el evento como para la exposición. La Tabla 18 muestra las variables con datos faltantes que fueron analizadas como posibles confusores.

Tabla 18. Porcentaje de valores faltantes de las variables analizadas como posibles factores de confusión

\begin{tabular}{|c|c|c|c|c|}
\hline & $\begin{array}{l}\text { Controles } \\
(n=330)\end{array}$ & $\begin{array}{l}\text { Casos } \\
\text { confirmados } \\
(n=66)\end{array}$ & $\begin{array}{l}\text { Casos } \\
\text { sospechosos } \\
(n=211)\end{array}$ & $\begin{array}{l}\text { Cohorte } \\
(n=906)\end{array}$ \\
\hline Tamaño del hogar & $0.0 \%$ & $1.5 \%$ & $0.9 \%$ & $0.1 \%$ \\
\hline Nivel educativo & $0.0 \%$ & $0.0 \%$ & $0.0 \%$ & $1.5 \%$ \\
\hline Ir a centro de salud si diarrea & $0.0 \%$ & - & - & $0.0 \%$ \\
\hline $\begin{array}{l}\text { Familiar del hogar con cólera la } \\
\text { semana anterior }\end{array}$ & $0.6 \%$ & $1.5 \%$ & $0.9 \%$ & $0.5 \%$ \\
\hline Familiar del hogar con cólera ahora & $0.0 \%$ & $4.5 \%$ & $3.3 \%$ & $0.1 \%$ \\
\hline Usa fuente de agua potable * & $1.8 \%$ & $1.5 \%$ & $4.3 \%$ & $24.4 \%$ \\
\hline Tratamiento del agua de consumo & $0.0 \%$ & $1.5 \%$ & $1.9 \%$ & $0.8 \%$ \\
\hline $\begin{array}{l}\text { Comparte fuente de agua de consumo } \\
\text { con un paciente de cólera }\end{array}$ & $9.1 \%$ & $10.6 \%$ & $14.7 \%$ & $7.4 \%$ \\
\hline Comió comida comprada en la calle & $1.5 \%$ & $1.5 \%$ & $2.4 \%$ & $0.3 \%$ \\
\hline Jabón disponible (autoreportado) & $0.0 \%$ & $1.5 \%$ & $0.9 \%$ & $0.0 \%$ \\
\hline $\begin{array}{l}\text { Tiene saneamiento mejorado * } \\
\text { (autoreportado) }\end{array}$ & $0.0 \%$ & $1.5 \%$ & $0.9 \%$ & $0.0 \%$ \\
\hline Letrina inundada (autoreportado) & $5.2 \%$ & $15.2 \%$ & $11.4 \%$ & $0.0 \%$ \\
\hline $\begin{array}{l}\text { Comparte letrina con alguien con } \\
\text { diarrea }\end{array}$ & $1.5 \%$ & $4.5 \%$ & $3.3 \%$ & $5.6 \%$ \\
\hline
\end{tabular}

El análisis crudo no se vió afectado por los datos faltantes ya que la base de datos no contenía ninguna información ausente para el evento de interés, la exposición o el par. En el análisis multivariado, las dos variables identificadas como posibles factores de confusión contenían datos faltantes y analizamos la posible influencia de los datos faltantes en las estimaciones ajustadas de la efectividad vacunal. 
La Tabla 19 muestra las estimaciones ajustadas de la efectividad vacunal para cada una de las tres estrategias usadas para el tratamiento de valores faltantes. Incluimos como efectividad vacunal ajustada la estimación puntual y los intervalos de confianza obtenidos con los datos faltantes imputados usando la imputación múltiple con ecuaciones encadenadas.

Tabla 19. Estimaciones ajustadas de la EV considerando diversas estrategias de manejo de datos faltantes y por diseño

\begin{tabular}{|c|c|c|c|c|c|c|}
\hline & \multicolumn{2}{|c|}{ TNCC } & \multicolumn{2}{|c|}{ MCC } & \multicolumn{2}{|c|}{ CC } \\
\hline & $\begin{array}{c}\text { EV } \\
\text { ajustada } \\
*\end{array}$ & IC95\% & $\begin{array}{c}\text { EV ajustada } \\
* *\end{array}$ & IC95\% & $\begin{array}{c}\text { EV } \\
\text { ajustada } \\
\dagger\end{array}$ & IC95\% \\
\hline $\begin{array}{l}\text { Exclusión de las entradas } \\
\text { con valores faltantes }\end{array}$ & $81.2 \%$ & $(19.2-95.6)$ & $86.5 \%$ & (29.1-97.4) & $94.0 \%$ & $(52.5-99.2)$ \\
\hline $\begin{array}{l}\text { Datos faltantes como una } \\
\text { variable ficticia }\end{array}$ & $80.9 \%$ & $(20.5-95.4)$ & $87.4 \%$ & $(30.9-97.7)$ & $89.2 \%$ & $(64.4-96.7)$ \\
\hline $\begin{array}{l}\text { Imputación multiple de } \\
\text { valores faltantes }\end{array}$ & $80.2 \%$ & $(16.9-95.3)$ & $88.9 \%$ & (42.7-97.8) & $89.4 \%$ & $(64.6-96.9)$ \\
\hline
\end{tabular}

*TND: EV ajustada por edad, nivel de educación, frecuencia del tratamiento de agua de consumo y contacto (variable combinada que considera aquellos con un miembro en el hogar con cólera en la semana anterior o comparten la fuente de agua de consumo con un paciente de cólera como "expuestos"). Vivir en un área seleccionado por la campaña de vacunación se incluyo como una variable de estratificación en el modelo de regresión.

**MCC: EV ajustada por contacto. Vivir en un área seleccionado por la campaña de vacunación se incluyó como una variable de estratificación en el modelo de regresión.

†CC: EV ajustada por edad, sexo, número de niños menores de 5 años viviendo en el hogar, acceso a agua potable y lugar de defecación.

\subsubsection{Análisis de sensibilidad}

\subsubsection{Análisis de sensibilidad considerando el estado vacunal.}

Evaluamos la exposición a la vacuna de forma autorreportada y lo verificamos a través del carné de vacunación. El estado vacunal autorreportado podría verse afectado por el hecho de haber padecido un episodio de cólera y, por tanto, podría diferir según el estado de caso o de control, mientras que el extravío de los carnés de vacunación podrían conducir a una subestimación de la cobertura vacunal. Para los análisis primarios utilizamos el estado vacunal autorreportado. Para evaluar la 
sensibilidad de nuestros resultados con este supuesto, estimamos la efectividad vacunal utilizando dos esquemas alternativos de clasificación del estado vacunal:

1. Clasificando a quienes reportaron haber sido vacunados sin tener un carné de vacunación como no vacunado

2. Excluyendo a aquellos que reportaron haber sido vacunados sin tener un carné de vacunación.

Tabla 20. Análisis de sensibilidad del estado vacunal excluyendo a los individuos sin carné de vacunación y considerando los individuos sin carné como vacunados

\begin{tabular}{|c|c|c|c|c|c|c|c|}
\hline & Controles & & Casos & & EV & IC 95\% & Valor $\mathbf{P}$ \\
\hline & $\mathrm{N}$ & $(\%)$ & $\mathrm{N}$ & $(\%)$ & $\%$ & & \\
\hline \multicolumn{8}{|l|}{ Estado vacunal } \\
\hline No vacunados & 286 & $(86,7)$ & 63 & $(95,5)$ & & & \\
\hline Vacunados (con carné) & 21 & $(6,4)$ & 2 & (3) & & & \\
\hline Vacunados (sin carné) & 23 & $(6,9)$ & 1 & $(1,3)$ & & & \\
\hline \multicolumn{8}{|c|}{ Aquellos sin carné como vacunados } \\
\hline No vacunados & 286 & (87) & 63 & (95) & Ref & & \\
\hline Vacunados (con y sin carné) & 44 & (13) & 3 & (5) & 84,7 & $(27-96,6)$ & 0,017 \\
\hline \multicolumn{8}{|c|}{ Aquellos sin carné como no vacunados } \\
\hline No vacunados & 309 & $(93,6)$ & 64 & $(97)$ & Ref & & \\
\hline Vacunados (con carné) & 21 & $(6,4)$ & 2 & (3) & 62,9 & $(-93,4-92,9)$ & 0,239 \\
\hline \multicolumn{8}{|l|}{ Aquellos carné como vacunados } \\
\hline No vacunados & 267 & $(92,7)$ & 63 & $(96,9)$ & Ref & & \\
\hline Vacunados (con carné) & 21 & $(7,3)$ & 2 & $(3,1)$ & $8300 \%$ & $(-52,98,1)$ & 0,113 \\
\hline
\end{tabular}

Las estimaciones se mantenían estables cuando se eliminaron aquellos sin carné de vacunación. Sin embargo, el pequeño tamaño muestral reducía la precisión de las estimaciones de efectividad vacunal.

\subsubsection{Análisis de sensibilidad considerando la distancia entre el caso y su control}

Para controlar por la cobertura vacunal local y el riesgo de infección usamos el pareamiento geográfico, que teóricamente nos debería conducir a estimaciones directas de efectividad vacunal. Sin embargo, no está claro cuál podría ser la escala espacial más adecuada para el emparejamiento. Para evaluar la sensibilidad de nuestros resultados a la distancia entre el control y su caso (es decir, la escala espacial), estimamos la efectividad vacunal en las áreas vacunadas utilizando dos esquemas alternativos de clasificación del estado vacunal:

1. Excluyendo los pares con una distancia entre ellos de más de $150 \mathrm{~m}$ 
2. Excluyendo los pares con una distancia entre ellos de más de $300 \mathrm{~m}$

Con ambos enfoques, encontramos que nuestras estimaciones de EV excluyendo los pares con una distancia entre ellos de más de 150 metros estaban dentro del $4 \%$ de las estimaciones originales. (Ver Tabla 21)

Tabla 21. Análisis de sensibilidad del estado vacunal en los paticipantes que vivían en las áreas objeto de la campaña de vacunación excluyendo los pares cuya distancia entre el control y su caso era de más de $150 \mathrm{~m}$, más de $300 \mathrm{~m}$ y sin exclusión de distancia

\begin{tabular}{|c|c|c|c|c|}
\hline & Controles & Casos & EV cruda & Valor $p$ \\
\hline & \multicolumn{2}{|c|}{ no de pacientes(\%) } & $95 \%$ & \\
\hline \multicolumn{5}{|c|}{ Sensitive analysis distance case-control } \\
\hline \multicolumn{5}{|l|}{$<150 m$} \\
\hline No vacunados & $44(58,7)$ & $18(85,7)$ & Ref & \\
\hline Vacunados & $31(41,3)$ & $3(14,3)$ & $80,3 \%(6,8-95,8)$ & $<0,005$ \\
\hline \multicolumn{5}{|l|}{$<300 m$} \\
\hline No vacunados & $54(59,3)$ & $18(85,7)$ & Ref & \\
\hline Vacunados & $37(40,7)$ & $3(14,3)$ & $85,1 \%(28,4-96,9)$ & $<0,005$ \\
\hline \multicolumn{5}{|c|}{ No distance restriction } \\
\hline No vacunados & $62(59,6)$ & $18(85,7)$ & Ref & \\
\hline Vacunados & $42(40,4)$ & $3(14,3)$ & $84,0 \%(25,2-96,6)$ & $<0,005$ \\
\hline
\end{tabular}




\subsection{Encuesta de cobertura al final de la campaña de vacunación con OCV.}

\subsubsection{Descripción de la muestra}

Enntre el 3 y 17 de marzo de 2017 se visitaron un total de 478 hogares.

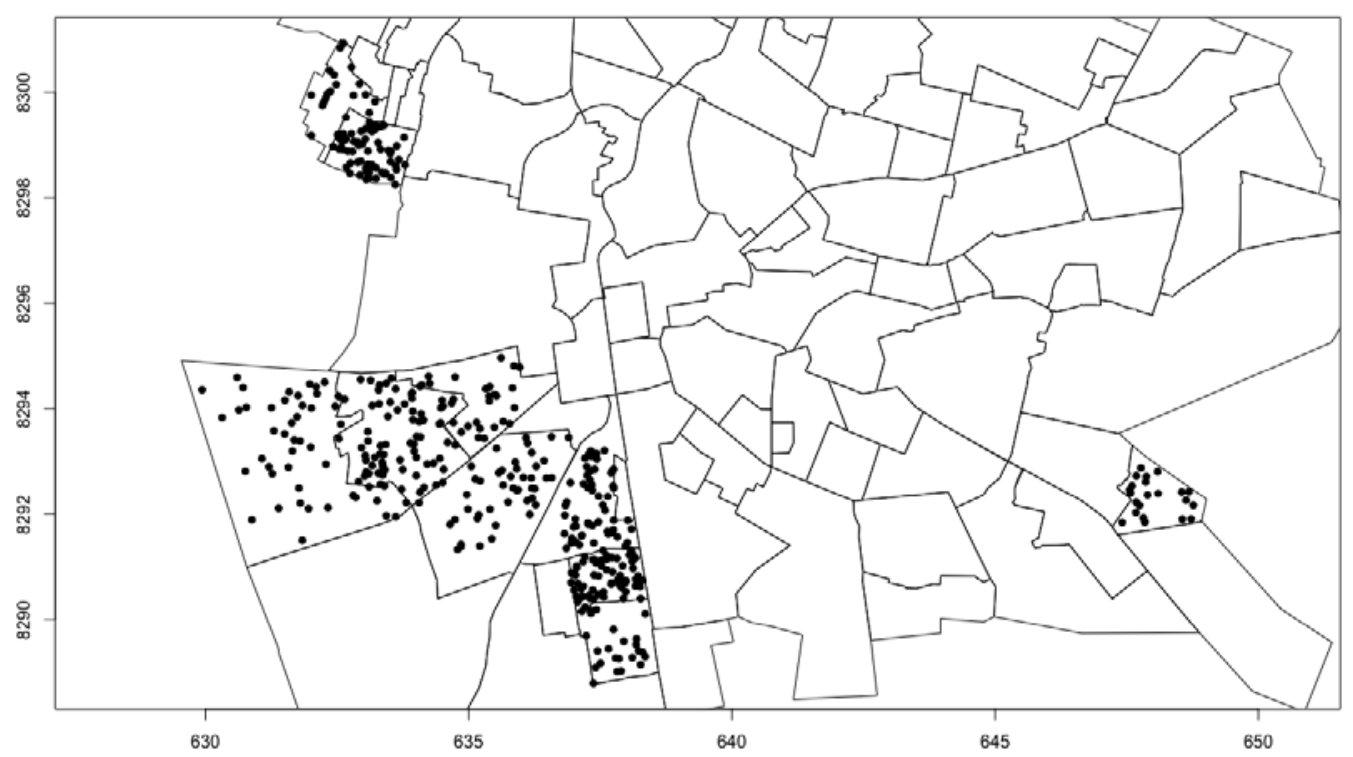

Figura 28. Mapa de Lusaka por municipios

Los puntos son los participantes de la encuesta de cobertura.

De éstos, 467 individuos fueron seleccionados para participar en la encuesta ya que, después de dos visitas, no pudimos encontrar los habitantes de 11 de los hogares. Entre estos individuos, 18 se negaron a participar y 7 no eran elegibles para participar en la encuesta. Las razones para no participar se describen en la Tabla 22.

Tabla 22. Motivos de rechazo a participar en la encuesta

\begin{tabular}{llc}
\hline & $\mathbf{n}$ & $\mathbf{\%}$ \\
\hline No quiere que le hagan preguntas. & 5 & 27,8 \\
Creencias religiosas & 2 & 11,1 \\
Miedo por los incidentes del año pasado & 2 & 11,1 \\
No está cómodo/a & 2 & 11,1 \\
No está interesado/a & 4 & 22,2 \\
No se siente bien & 1 & 5,6 \\
Ocupado/a & 2 & 11,1 \\
\hline
\end{tabular}


Al final, incluimos 442 individuos en el análisis. El tamaño medio de los hogares era de 4 habitantes (desviación estándar: 2,4). La mediana de edad fue de 21 años (rango intercuartílico (IQR): 10-34 años). La relación hombre/mujer fue de 0,64.

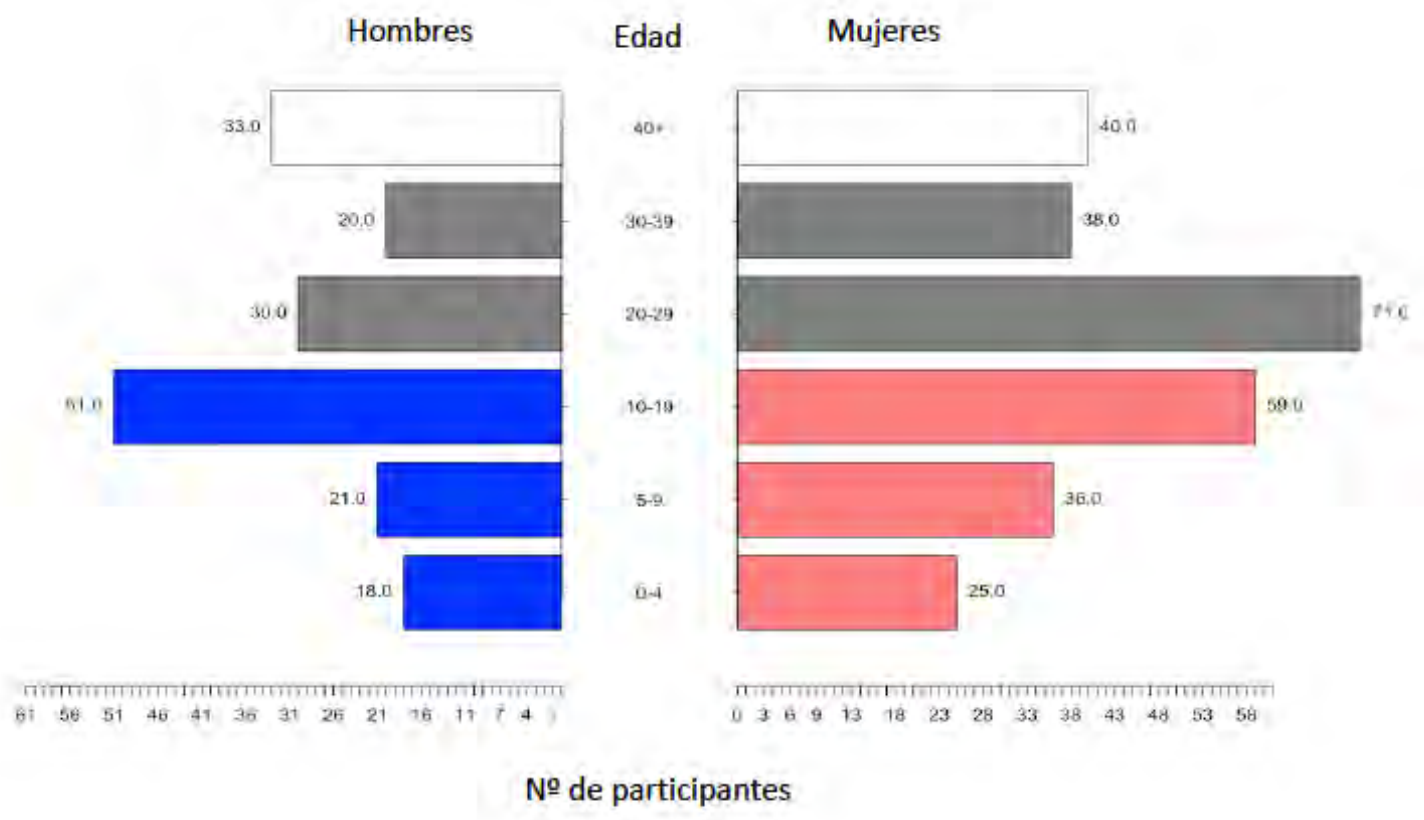

Figura 29. Pirámide poblacional de las personas participantes de la encuesta

\subsubsection{Segunda ronda de vacunación: Diciembre de 2016}

El 59\% (n= 261/442; IC 95\%: 54,3-63,7) de la población objeto de la campaña recibió una dosis de la vacuna durante la segunda ronda de vacunación con OCV en diciembre de 2016. El 24\% del total de los individuos encuestados que reportaban haber sido vacunados poseían el carné de vacunación. Los menores entre 5 y 15 años presentaban una cobertura vacunal del 68,1\% (79/116; IC95\%: 58,8-76,4) y los adultos del 32.7\% (92/281; 95\%CI: 27.3-38.6). Ver Tabla 23.

\subsubsection{Primera ronda de vacunación: Abril de 2016}

En marzo de 2017, el 44,8\% ( $n=198 / 442$; IC 95\%: 40,0-49,6) de las personas que vivían en las áreas objeto de la campaña de vacunación reportaron haber recibido una dosis de la vacuna durante la primera ronda (realizada en abril de 2016). El porcentaje de retención del carné de vacunación fue del 27,9\%. 


\subsubsection{Cobertura vacunal global con dos dosis y con una dosis única}

La cobertura vacunal con dos dosis de OCV fue del 33,9\% $(n=150 / 442$; IC 95\%: 29,5-38,6) entre la población objeto de la campaña y el 36\% reportó haber recibido una sola dosis de vacuna ( $\mathrm{n}=159 / 442$; IC del 95\%: 31,5-40,6). El porcentaje de abandono (individuos que reportaron haber tomado la vacuna en abril de 2016 y que no recibieron la segunda dosis en diciembre) fue del 10,9\% (IC 95\%: 8,1-14,1). De forma global, el 69,9\% ( $\mathrm{n}=309 / 442$; IC95\%: 65,4-74,1) reportaron haber recibido al menos una dosis de vacuna en el momento de la encuesta de cobertura.

\subsubsection{Análisis estratificado}

La Tabla 23 muestra la cobertura vacunal global con dos dosis, una dosis y la cobertura alcanzada en la primera y segunda rondas de vacunación estratificadas por grupo de edad, sexo y municipio. 
Tabla 23. Cobertura vacunal (CV) por grupo de edad, sexo y municipio

\begin{tabular}{|c|c|c|c|c|c|c|c|c|c|c|}
\hline & \multicolumn{2}{|r|}{$\mathrm{CV}$ con 2 dosis } & \multicolumn{2}{|r|}{ CV con 1 dosis } & \multicolumn{2}{|c|}{ CV con al menos 1 dosis } & \multicolumn{2}{|c|}{ CV de la $1^{\mathrm{a}}$ ronda * } & \multicolumn{2}{|c|}{ CV de la $2^{a}$ ronda } \\
\hline & $\mathbf{n}$ & $\%(95 \% \mathrm{CI})$ & $\mathbf{n}$ & $\%(95 \% \mathrm{CI})$ & $\mathbf{N}$ & $\%(95 \% \mathrm{CI})$ & $\mathbf{n}$ & $\%(95 \% \mathrm{CI})$ & $\mathbf{n}$ & $\%(95 \% \mathrm{CI})$ \\
\hline CV global & 150 & $33.9(29.5-38.6)$ & 159 & $36.0(31.5-40.6)$ & 309 & $69.9(65.4-74.1)$ & 198 & $44.8(40.0-49.6)$ & 261 & $59.0(54.3-63.7)$ \\
\hline 1 a 5 años & 25 & $58.1(42.1-72.9)$ & 13 & $30.2(17.2-46.1)$ & 38 & $88.4(74.9-96.1)$ & 27 & $62.8(46.7-77.0)$ & 36 & $83.7(69.3-93.2)$ \\
\hline 5 a15 años & 69 & $59.5(49.9-68.5)$ & 38 & $32.7(24.3-42.1)$ & 107 & $92.2(85.8-96.4)$ & 79 & $68.1(58.8-76.4)$ & 97 & $83.6(75.6-89.8)$ \\
\hline +15 años & 56 & $19.9(15.4-25.1)$ & 108 & $38.4(32.7-44.4)$ & 164 & $58.4(52.4-64.2)$ & 92 & $32.7(27.3-38.6)$ & 128 & $45.5(39.6-51.6)$ \\
\hline Mujeres & 96 & $35.8(30.1-41.9)$ & 107 & $40.0(34.0-46.1)$ & 268 & $75.7(70.2-80.7)$ & 132 & $49.2(43.1-55.4)$ & 167 & $62.3(56.2-68.1)$ \\
\hline Hombres & 54 & $31.4(24.5-38.9)$ & 52 & $30.2(23.5-37.7)$ & 106 & $61.6(53.9-68.9)$ & 66 & $38.4(31.1-46.1)$ & 94 & $54.6(46.9-62.2)$ \\
\hline Bauleni & 6 & $27.3(10.7-50.2)$ & 9 & $41(20.7-63.6)$ & 15 & $68.2(45.1-86.1)$ & 7 & 31.8 (13.9-54.9) & 14 & $63.6(40.6-82.8)$ \\
\hline Chawama & 23 & $35.4(23.9-48.2)$ & 26 & $40(28-52.9)$ & 49 & $75.4(63.1-85.2)$ & 27 & $41.5(29.4-54.4)$ & 45 & $69.2(56.5-80.1)$ \\
\hline George & 24 & $38.1(26.1-51.2)$ & 23 & $36.5(24.7-49.6)$ & 47 & $74.6(62.1-84.7)$ & 36 & $57.1(44.09-69.5)$ & 35 & $55.6(42.5-68.1)$ \\
\hline George-Soweto & 6 & $31.6(12.6-56.5)$ & 9 & $47.4(24.4-71.1)$ & 15 & $78.9(54.4-93.9)$ & 8 & $42.1(20.2-66.5)$ & 13 & $68.4(43.4-87.4)$ \\
\hline John-Howard & 10 & $41.7(22.1-63.4)$ & 9 & $37.5(18.8-59.4)$ & 19 & $79.2(57.8-92.9)$ & 10 & $41.7(22.1-63.3)$ & 19 & $79.2(57.8-92.9)$ \\
\hline Jhon Laing & 14 & $30.4(17.7-45.7)$ & 20 & $43.5(28.9-58.9)$ & 34 & $73.9(58.9-85.7)$ & 19 & $41.3(26.9-56.8)$ & 29 & $63.0(47.5-76.8)$ \\
\hline Kanyama West & 13 & $27.6(15.6-42.6)$ & 15 & $31.9(19.1-47.1)$ & 28 & $59.6(44.3-73.6)$ & 18 & $38.3(24.5-53.6)$ & 23 & $48.9(34.1-.63 .9)$ \\
\hline Misisi-Kuku & 21 & $37.5(24.9-51.4)$ & 19 & $33.9(21.8-47.8)$ & 40 & $71.4(57.8-82.7)$ & 27 & $48.2(34.6-61.9)$ & 34 & $60.7(46.7-73.5)$ \\
\hline New Kanyama & 6 & $23.1(8.97-43.6)$ & 6 & $23.1(8.9-43.6)$ & 12 & $46.1(26.6-66.6)$ & 10 & $38.5(20.2-59.4)$ & 8 & $30.8(14.3-51.8)$ \\
\hline Old Kanyana & 27 & $37.5(26.48-49.7)$ & 23 & $31.9(21.4-43.9)$ & 50 & $69.4(57.45-79.8)$ & 36 & $50.0(37.9-62)$ & 41 & $56.9(44.7-68.6)$ \\
\hline
\end{tabular}

*Esta estimación representa el porcentaje de personas viviendo en las áreas seleccionadas por la campaña de vacunación en marzo de 2017 que notificaron haber sido vacunadas en abril de 2016. 
La cobertura vacunal con dos dosis fue mayor en los menores entre 5 y 14 años (59,5\% (69/116; IC95\%: 49,9-68,5) que en las personas adultas (19,9\% (56/281; IC95\%: 15,4-25,1) y en las menores de 5 años (58,1\% (25/43 IC95\%: 42,1-72,9).

La cobertura vacunal con al menos una dosis fue mayor entre las mujeres $(75,7 \%$, IC 95\%: 70,2-80,7) que entre los hombres (61,6\%, IC 95\%: 53,9-68,9). Lo mismo sucede con la cobertura vacunal con dos dosis, que fue mayor entre las mujeres (35,8\%, IC 95\%: 30,1-41,9) que entre los hombres (31,4\%, IC 95\%: 24,5-38,9), en particular en las personas entre 25 y 50 años

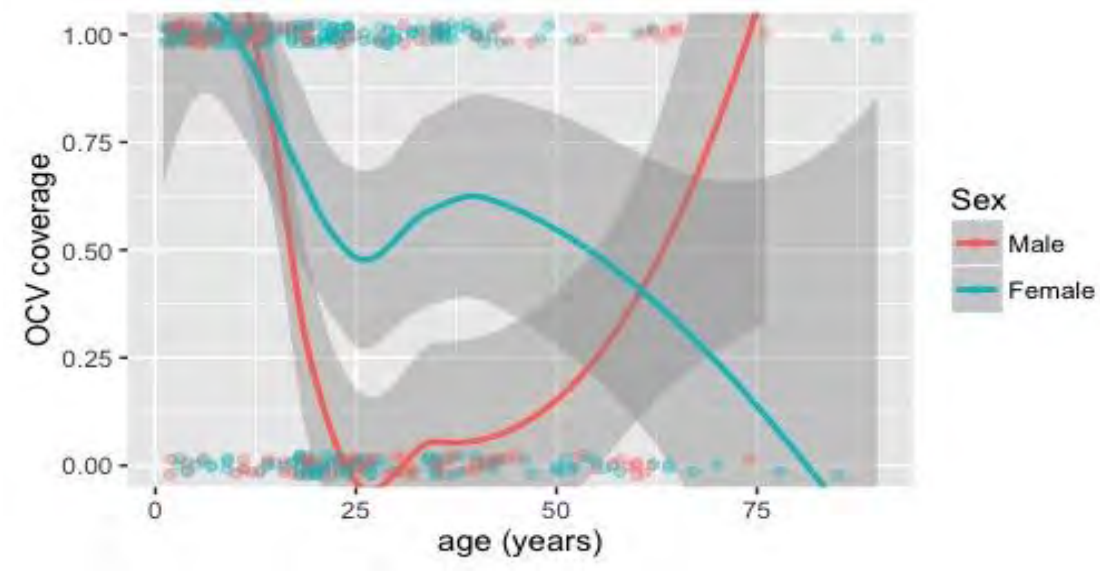

Figura 30. Cobertura vacunal con dos dosis por edad y sexo. Tomada de (128)

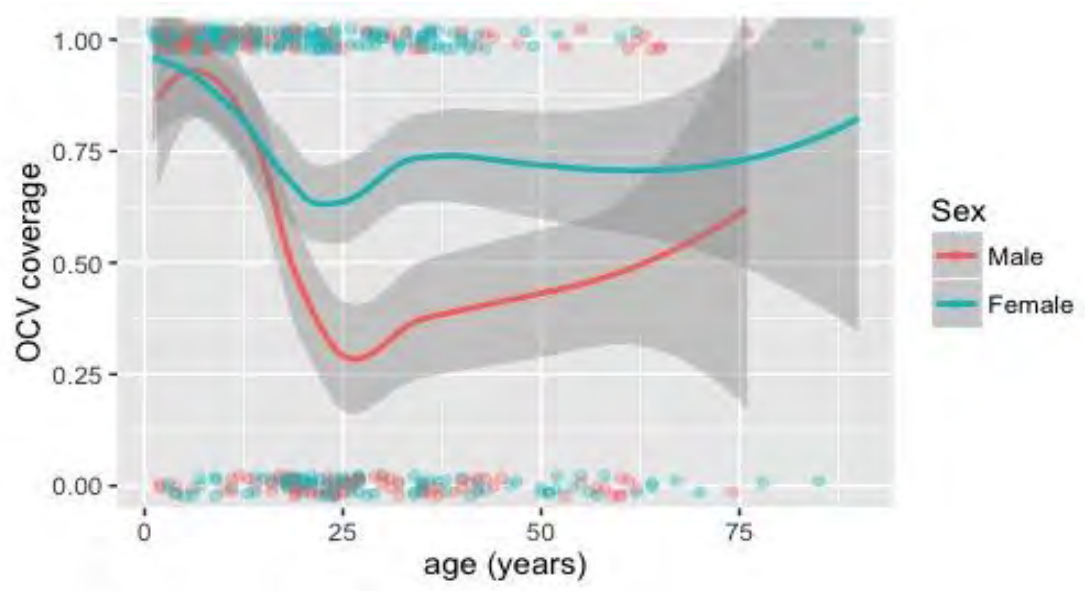

Figura 31. Cobertura vacunal con al menos una dosis por edad y sexo. Tomada de (128)

La cobertura vacunal varía según el municipio, observando la mayor cobertura con al menos una dosis de OCV en John-Howard (79,2\%, IC 95\%: 57,8-92,9) y la más baja en New Kanyama (46,1\%, IC 95\%: 26,6-66,6). La Figura 32 muestra la 
distribución geográfica de la cobertura vacunal en las diferentes áreas seleccionadas por la campaña. Este mapa indica que hay áreas con una mejor cobertura que otras, tal y como lo indica el análisis estratificado, pero también que dentro de algunos municipios como Kanyama, existía una alta heterogeneidad interna en la cobertura vacunal.
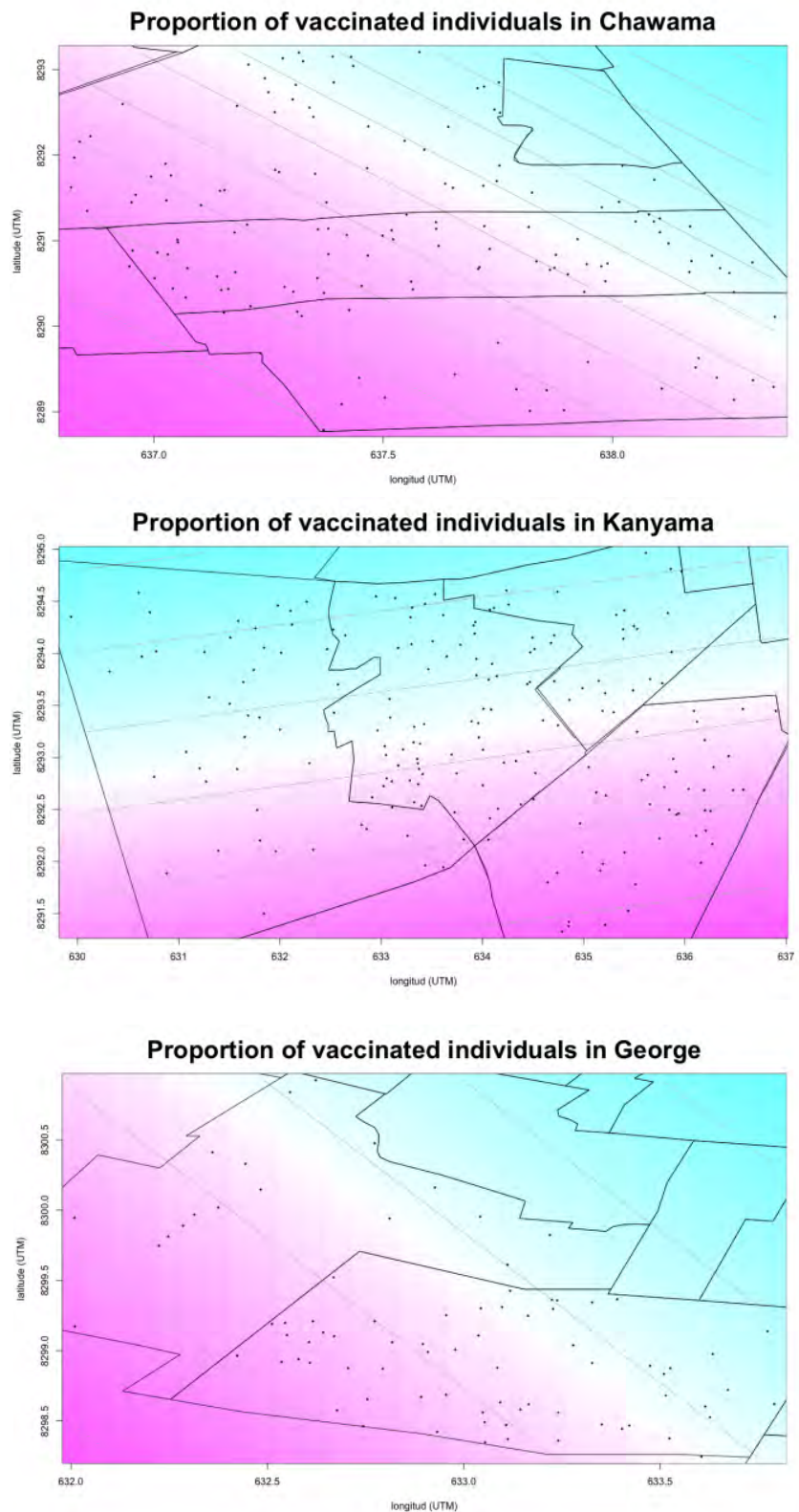

Figura 32. Distribución geográfica de la CV en Kanyama, Chawama y George 


\subsubsection{Causas del rechazo a la vacunación}

La causa más frecuente de rechazo a la vacunación es el hecho de estar ausente durante la campaña $(27,7 \%$ para la primera ronda y $25,7 \%$ para la segunda ronda). La segunda razón era la falta de tiempo (19,8\% y 24,4\%) y la tercera que en la zona donde vivía no había campaña de vacunación $(10,7 \%$ y 6,7\%). La lista completa de causas para no vacunarse se encuentra en la Tabla 24.

Tabla 24: Causas para el rechazo a la vacunación

\begin{tabular}{|c|c|c|c|c|}
\hline & \multicolumn{2}{|c|}{$1^{\underline{a}}$ ronda } & \multicolumn{2}{|c|}{$2^{\mathrm{a}}$ ronda } \\
\hline & $\mathbf{n}$ & $\%$ & $\mathbf{n}$ & $\%$ \\
\hline No había campaña de vacunación donde vivía. & 26 & 10.7 & 12 & 6.7 \\
\hline No sabía que había otra campaña de vacunación. & 20 & 8.2 & 10 & 5.6 \\
\hline Pensó que no era elegible. & 7 & 2.9 & 1 & 0.6 \\
\hline No sabía la fecha de la campaña. & 7 & 2.9 & 4 & 2.2 \\
\hline No sabía el lugar de la campaña. & 1 & 0.4 & - & - \\
\hline Rechazo por motivos religiosos. & 1 & 0.4 & 1 & 0.6 \\
\hline Consideraba que la vacuna era peligrosa. & 5 & 2.1 & 2 & 1.1 \\
\hline Consideraba que había que esperar mucho. & 1 & 0.4 & - & - \\
\hline Consideraba el puesto de vacunación demasiado lejos. & 1 & 0.4 & 2 & 1.1 \\
\hline Ausente durante la campaña. & 67 & 27.7 & 46 & 25.7 \\
\hline No tenía tiempo. & 49 & 20.2 & 43 & 24.0 \\
\hline Estaba enfermo durante campaña de vacunación. & 3 & 1.2 & 5 & 2.8 \\
\hline Había tenido malas experiencias con otras campañas en el pasado. & 2 & 0.8 & 4 & 2.2 \\
\hline Estaba hospitalizado durante campaña de vacunación & 1 & 0.4 & - & - \\
\hline El vacunador rechazó darle la vacuna. & - & - & 1 & 0.6 \\
\hline Decidió no tomar la vacuna porque estaba embarazada. & 1 & 0.4 & 4 & 2.2 \\
\hline Mal sabor. & 1 & 0.4 & 2 & 1.1 \\
\hline No dio ninguna explicación. & 16 & 6.6 & 10 & 5.6 \\
\hline Otra & 32 & 13.2 & 32 & 17.9 \\
\hline
\end{tabular}

\subsubsection{Eventos adversos después de la inmunización.}

En la encuesta se recogían los eventos adversos después de la inmunización (tanto en la primera como en la segunda ronda de vacunación). Entre los que recibieron la vacuna, el 19,7\% ( $n=39)$ declaró haber estado enfermo después de la primera ronda y el 24,1\% $(n=63)$ después de la segunda ronda. Los principales signos o 
síntomas reportados, después de la primera y segunda ronda, respectivamente, fueron náuseas, diarrea, fiebre y dolor abdominal. Entre los que dijeron que experimentaron efectos secundarios, nadie reportó haber acudido a un hospital, centro de salud o clínica después de la primera ronda, pero sí el 7,9\% (n=5/63) después de la segunda ronda. Todos los síntomas están enumerados en la Tabla 25.

Tabla 25. Eventos adversos reportados después de la inmunización

\begin{tabular}{|c|c|c|c|c|}
\hline & \multicolumn{2}{|c|}{ 1a ronda } & \multicolumn{2}{|c|}{$2^{a}$ ronda } \\
\hline & $\mathbf{n}$ & $\%$ & $\mathbf{N}$ & $\%$ \\
\hline Fiebre & 2 & 5,1 & 3 & 4,8 \\
\hline Diarrea & 4 & 10,3 & 13 & 19 \\
\hline Dolor abdominal & 1 & 2,6 & 2 & 3,2 \\
\hline Naúseas & 31 & 79,5 & 40 & 63,5 \\
\hline Cefaleas & 1 & 2,6 & 1 & 1,6 \\
\hline Debilidad general & - & - & 2 & 3,2 \\
\hline
\end{tabular}


DISCUSIÓN 


\section{DISCUSIÓN}

\subsection{Revisión sistemática y meta-análisis de vacunas inactivadas orales frente al cólera.}

Encontramos que la OCV administrada con una pauta de vacunación estándar de dos dosis proporciona un nivel de protección de moderado a alto durante al menos 3 años, con alguna evidencia que sugiere una duración de a más largo plazo. El esquema de una dosis proporciona una protección significativa a corto plazo. Sin embargo, hasta donde hemos podido revisar, no existen estudios con una variable primaria de evaluación de más de 6 meses. La eficacia de dos dosis es significativamente menor en los menores de 5 años.

La elección entre usar un esquema de una o dos dosis es compleja, particularmente en los brotes de países donde existe una escasez en el stock de vacunas (129-131). Nuestras estimaciones promedio de efectividad vacunal a corto plazo (hasta 1 año después de la vacunación) tanto con una como con dos dosis son similares. Sin embargo, esta comparativa no fue posible para los estudios de eficacia vacunal debido a la escasez de estudios. Cuando se necesita protección a corto plazo y no se pueden proporcionar dos dosis a todas las personas en riesgo, nuestros resultados sugieren que una dosis única podría proporcionar el mismo nivel de protección a corto plazo que la pauta vacunal de dos dosis. La mayoría de la evidencia científica para el esquema de dosis única proviene de estudios observacionales. Se necesita más evidencia por parte de ensayos clínicos para corroborar la creciente evidencia de los estudios observacionales que apoya la fuerte protección conferida por el esquema de una dosis. Existe un estudio que compara la eficacia a corto plazo de tres dosis de vacuna tanto con BivWC como con WC-rBS que muestra que la WCrBS confería una protección a corto plazo alta y la BivWC moderada, y concluye con que la inclusión de la subunidad B de toxina colérica recombinante podría ser la responsable del incremento de la protección a corto plazo (65). Si este hallazgo refleja una verdadera diferencia, una vacuna de dosis única WC-rBS podría proporcionar una alternativa con una mayor protección que la vacuna de células enteras. Si hay que proporcionar una dosis de refuerzo, y cuándo, sigue siendo una 
pregunta abierta y que varía según el grado en que la población haya estado previamente expuesta al Vibrio cholerae. A medida que se genere más evidencia sobre la duración de la protección conferida tanto por el régimen de dosis única como de dos dosis, aumentará la capacidad de una mejor toma de decisiones de cuando se debería usar cada pauta vacunal y el intervalo en el cual se debería administrar la dosis de refuerzo.

Las OCV, como otras vacunas orales (132), proporcionan menos protección a los niños y niñas menores de 5 años que a las personas con 5 años de edad o más. Esta diferencia de protección en función la edad podría tener implicaciones para decidir entre diferentes estrategias de vacunación, particularmente cuando se amplia su uso en países altamente endémicos como en Bangladesh. De todas formas, a pesar de la menor eficacia, la vacunación en las niñas y niños más pequeños podría tener efectos sustanciales sobre la carga de la enfermedad debido a los efectos indirectos de la vacuna (inmunidad de rebaño)(133). Son necesareos más estudios para afinar las estimaciones de protección vacunal por edad y asi aumentar la comprensión del efecto de diferentes estrategias de administración de vacunas dirigidas a diferentes grupos de edad y entender si pautas vacunales alternativas, tales como la administración de una tercera dosis, podría mejorar la protección en niños y niñas pequeños.

La epidemiología del cólera a nivel local, incluyendo las vías e intensidad de la transmisión, puede determinar qué grupos de edad tienen mayor riesgo de infectarse (134). En contextos altamente endémicos de cólera, como Bangladesh e India, las personas con cólera tienden a ser más jóvenes ya que las adultas se benefician de la protección conferida por la exposición previa a Vibrio cholerae. Dado que la eficacia de la OCV es dependiente de la edad, la distribución de la edad de las personas probablemente influye en las estimaciones de protección de los estudios realizados en diferentes contextos. La exposición frecuente en áreas endémicas puede actuar incrementando la inmunidad inducida por la vacuna y prolongar la duración de la protección, pudiendo influir en la protección aparente de la vacuna. Estos hechos, además de las diferencias en la duración de los estudios, podrían explicar por qué la efectividad vacunal de dos dosis es más alta 
que la eficacia vacunal (figura 16). India es el único país en el que se han realizado tanto estudios de eficacia (78) como de efectividad (123) con dos dosis de OCV, siendo las estimaciones de la protección a los 3 años de la vacunación muy similares (66\% y 69\% respectivamente). Esto demuestra que la epidemiología a nivel local podría explicar las diferencias aparentes entre los diseños de los estudios.

Por otro lado, en los estudios a nivel individual identificamos niveles de heterogeneidad de moderados a altos entre las estimaciones de la protección de la vacuna tanto en el análisis primario de eficacia con dos dosis como en el análisis de la efectividad promedio con una dosis. Aunque parte es explicada por la duración del estudio y la edad promedio de los pacientes, otros factores que no identificados podrían jugar un papel en dicha heterogeneidad. Un caso atípico en el análisis primario de eficacia con dos dosis lo tenemos con un ensayo clinico realizado en Perú (69), donde no se encontró protección durante los 10 meses posteriores a la vacunación. El estudio evaluó una variante de vacuna temprana producida antes de que existiera una producción a gran escala. Clemens et al sugirieron la posibilidad de una clasificación errónea de la varible "evento de interés" dentro del programa masivo de vigilancia activa basada en el hogar (con visitas dos veces por semana a 18.000 hogares), pudiendo haber sesgado los resultados hacía el efecto nulo (70).

Nuestra revisión sistemática tiene múltiples limitaciones. Debido a los pocos estudios disponibles y su diversidad en el diseño del estudio, la duración del seguimiento, el tipo de vacuna y los contextos epidemiológicos, no pudimos controlar completamente por cada factor para estimar el verdadero efecto promedio. Aquí presentamos estimaciones estratificadas para ayudar a interpretar cómo cada factor podría influir en las estimaciones de protección de la OCV. En nuestros análisis de protección con dosis única, combinamos las estimaciones de protección de dosis única de los estudios en los que fue el resultado primario y de los estudios en los que fue un resultado secundario. Especialmente en los estudios observacionales, estas estimaciones secundarias provienen de individuos que no recibieron el esquema de vacunación completo, lo que podría estar correlacionado 
con el riesgo de cólera. Si estos datos fueran de personas que no recibieron la pauta vacunal completa, podríamos haber subestimado la protección promedio con dosis única. Del mismo modo, el uso de ambos grupos de vacunas del estudio de Matlab (119), sin tener en cuenta la correlación entre ellos (grupo de placebo compartido), condujo a una ligera subestimación de la varianza en las estimaciones de eficacia vacunal promedio. Por último, aunque no se detectaron diferencias significativas entre las estimaciones de protección con diferentes tipos vacunas, el aumento de la protección antigénica con el tiempo y la inclusión de la subunidad B podrían explicar algunas diferencias no detectadas que la potencia de este estudio no pudo detectar. Sin embargo, las estimaciones promedio con dos dosis excluyendo las vacunas WC-rBS fueron similares a las estimaciones correspondientes a una combinación de ambas vacunas.

\subsection{Evaluación de la efectividad vacunal con una dosis}

Nuestro estudio confirma que una dosis de ShancholTM es suficiente para desarrollar una protección frente a la infección por cólera durante al menos dos meses después de la campaña de vacunación y que es una herramienta eficaz para el control de brotes en contextos urbanos. Además, los tres diseños que empleamos para el análisis encontraron niveles de protección comparables. Estos hallazgos son relevantes para establecer recomendaciones en el uso de vacunas como respuesta a brotes donde una protección alta a corto plazo es esencial.

Las estimaciones de EV usando el diseño de CC fueron similares a las reportadas en los análisis de MCC. El pareamiento a nivel espacial, realizándose en la escala apropiada, debería controlar las diferencias por la cobertura vacunal, proporcionando así una estimación de la protección directa de la vacuna (135). La similitud de las estimaciones de ambos diseños sugiere que la protección entre los individuos vacunados en Lusaka se debe principalmente al efecto directo de la vacuna. Sin embargo, no podemos descartar la posibilidad de que el emparejamiento espacial sea imperfecto, lo que permitiria la inclusión de controles procedentes de áreas con diferente cobertura vacunal y, por tanto, la inclusión de cierta protección indirecta en las estimaciones de eficacia vacunal del MCC. Un análisis de sensibilidad con diferentes tamaños de vecindario durante un 
estudio de cohorte en Zanzíbar sugiere que el efecto inmunidad de rebaño se mantenía estable hasta un radio de 500 m (73). En nuestro análisis de sensibidad, las estimaciones permanecen estables cuando se eliminan aquellos pares con una distancia de más de 150 m y de más de 300 m.

El análisis estratificado no tenía poder estadístico suficiente para detectar diferencias en subgrupos, pero reconfirma que la vacuna es protectora cuando restringimos el análisis a las áreas seleccionadas por la campaña de vacunación y a los casos con deshidratación severa. Además, el tamaño muestral de este estudio es relativamente grande en comparación con estudios anteriores, lo que ha permitido estimar la protección de la vacuna utilizando un diseño de casos y controles pareado, y por tanto, estimar el efecto directo de la vacuna (partiendo de la base que el lugar de residencia coincide en los pares de los casos y los controles y comparten niveles similares de cobertura vacunal). Esta fue una limitación importante en una evaluación de la protección vacunal de dosis única realizada en Sudán del Sur, previa a la nuestra, donde sólo se incluyeron 34 casos confirmados de cólera en el análisis con lo que el número limitado de pares discordantes impidió el uso del análisis de casos y controles pareado como análisis principal (90).

Además, el estudio de Lusaka se realizó en una población que no había sido expuesta al cólera recientemente. Estudios anteriores que miden la protección de una dosis plantean la posibilidad de que los esquemas de una dosis pudieran actuar principalmente como refuerzo de la inmunidad natural y que por tanto este esquema no fuera protector en poblaciones menos expuestas al cólera $(89,90,92)$. En Lusaka desde 2010 no se habían notificado ningún brote de cólera, lo que significa una ausencia de exposición masiva al cólera de cinco años. Por lo tanto, el contexto de Lusaka es una buena representación de zonas del mundo con tendencia a brotes de cólera donde períodos de calma se alternan con brotes explosivos, como ocurre en gran parte del África sub-sahariana. Según nuestros resultados, la pauta de vacunación con una dosis podría ser una herramienta excelente para controlar epidemias si las campañas de vacunación se implementan de forma oportuna y a tiempo. Sigue quedando por resolver la cuestión de si la 
dosis única sería suficiente para obtener protección en poblaciones con ausencia de inmunidad frente al cólera, como fue el caso de Haití en 2010.

Las estimaciones de efectividad aquí presentadas son casi idénticas a la protección con una dosis observada en el CC de Sudán del Sur (87\%) (86), y más altas que la protección medida en un ensayo clínico aleatorizado en Bangladesh frente al cólera severo (63\%) (88). Estas diferencias podrían ser explicadas por varios factores. Primero, es importante tener en cuenta que nuestras estimaciones solo son válidas para los primeros dos meses después de la ingesta de la vacuna, que comprende el mismo intervalo que el estudio realizado en Sudán del Sur. Esto difiere con las estimaciones de Bangladesh cuyo seguimiento se extiende a 6 meses. En nuestro estudio no fue posible un mayor tiempo de seguimiento ya que el brote fue controlado y no se reportaron más casos. No obstante, la protección inmediata después de la ingesta de vacuna es información esencial para la respuesta al brote, ya que éste es el período clave en el que se pueden producir la mayoría de los casos y fallecimientos (87). Otro factor que podría explicar las diferencias entre los estudios es la inmunidad de rebaño que confiere la OCV (75). El ensayo clínico realizado en Bangladesh fue un estudio aleatorizado a nivel individual y por tanto diseñado específicamente para medir la protección directa (88). Sin embargo, nuestro estudio es un estudio observacional, y por tanto permite la inclusión de protección indirecta en la estimación de la efectividad vacunal si el emparejamiento espacial no se realiza en la escala exacta donde ocurre la transmisión del cólera. Para explorar el efecto en las estimaciones de efectividad vacunal, llevamos a cabo un análisis de la distancia entre los pares de los casos y controles y, aunque no fue significativo, observamos que la estimación puntual era más baja cuando el análisis se restringía a menos de 50 metros, lo que indica que posiblemente podríamos incluir en nuestras estimaciones cierta protección indirecta. Esto también subraya la importancia de la transmisión en el hogar como componente clave en la propagación del cólera en Lusaka. Por otro lado, no podemos obviar la posibilidad de que el efecto de la inmunidad de rebaño esté confundiendo el verdadero efecto directo de la vacuna en Bangladesh ya que estudios previos han demostrado consistentemente una mayor protección directa en zonas con niveles de cobertura vacunal más bajos $(63,79)$. Adémas, es posible 
que nuestro estudio esté sobrerrepresentando los casos muy severos en comparación con el espectro de enfermedades incluidas en el estudio de Bangladesh, partiendo de la base de que nuestros métodos de vigilancia pasiva fueran probablemente menos sensibles para reclutar los casos leves a severos en comparación con la vigilancia activa establecida en un ensayo clínico. La OCV ha demostrado ser más efectiva frente enfermedades graves que para el cólera leve. En este sentido nuestras estimaciones deben interpretarse como protección a corto plazo para la infección severa por cólera. Por último y quizás más importante, el rango de edad de los casos confirmados de nuestro estudio es similar al rango de edad de los casos confirmados en Sudán del Sur (el 17\% de los participantes eran menores de 5 años) y mayor que el de Bangladesh (el 58\% eran menores de 5 años). Tal y como observamos durante el meta-análisis de los estudios con OCV, existe un efecto diferencial debido a la edad que podría explicar buena parte de las diferencias entre los estudios publicados de la estimación de la protección vacunal.

Un estudio implementado en Odisha (India) que utilizaba el TNCC como análisis principal y el de cohorte para validar los resultados principales, mostró que la incidencia de diarrea no colérica entre los vacunados era 2,7 veces mayor que entre los no vacunados, indicando o bien diferencias en los niveles de riesgo de enfermedades diarreicas o una heterogeneidad en el comportamiento de búsqueda de atención sanitaria entre los vacunados y los no vacunados (123). Nuestro análisis utilizando el diseño TNCC encontró estimaciones de efectividad vacunal equivalentes a las del MCC, dándo garantía de no haber cometido un sesgo grave de comportamiento de búsqueda de atención sanitaria. Además, el análisis del indicador de sesgo mostró que la probabilidad de vacunación no variaba significativamente entre los casos de diarrea no colérica y sus controles, con lo que apoya la robustez de nuestras estimaciones de EV en relación con el sesgo de comportamiento de búsqueda de atención sanitaria.

La principal limitación de nuestro estudio es el corto período de tiempo de seguimiento que comprende sólo los dos primeros meses después de la ingesta de la vacuna ya que las inclusiones en el estudio se detuvieron el 15 de junio, dos 
semanas después del último caso confirmado. Además, dos sesgos importantes podrían haber afectado nuestros resultados: el posible sesgo de clasificación errónea (tanto para el evento de interés (cólera confirmado) como para la exposición (vacunación con OCV)) y el sesgo de selección relacionado con la distribución no aleatoria de la exposición.

Para reducir el riesgo de clasificación errónea del evento de interés establecimos dos procedimientos de diagnóstico diferentes: el cultivo mediante procedimientos estándar y la PCR. La especificidad tanto del cultivo como de la PCR se considera del 100\%, aunque se ha demostrado que la PCR es más sensible que el cultivo para detectar cólera cuando se han usado antibióticos antes de la toma de la muestra. En nuestro caso, además de los 62 casos confirmados por cultivo, detectamos 4 casos adicionales que eran negativos para el cultivo pero positivos para la PCR. Usando la experiencia de estudios anteriores $(89,90)$, implementamos varios procedimientos para limitar el riesgo de clasificación errónea relacionada con la exposición incluyendo un procedimiento estándar y sistemático para introducir la campaña de vacunación a los participantes del estudio dando información sobre los organizadores de la campaña, fechas y lugares de vacunación. Durante esta explicación se mostraban imágenes de la vacuna y de un adulto tomando una dosis para identificar claramente el antígeno. Para aquellos que reportaron haber sido vacunados, les preguntamos si podían mostrar el carné de vacunación distribuido durante la campaña de vacunación y tomamos una foto si estaba disponible. Nos encontramos con que el porcentaje de retención del carné (52\%) fue menor en comparación con otros estudios $(88,136)$, lo que podría estar relacionado con el estricto proceso seguido para determinar el estado vacunal. Varias personas informaron haber perdido sus carnés de vacunación y otras que su carné se estropeó debido a la baja calidad del material (papel) de los carnés de vacunación

Durante la selección de los controles, excluimos a aquellos que buscaron tratamiento por diarrea entre el 1 de enero de 2016 y la fecha de inicio de la diarrea del caso al cual le pareabamos porque no estaban en riesgo y por tanto podrían sesgar la estimación de la efectividad vacunal. Con respecto al posible sesgo de selección, es importante mencionar que el porcentaje de individuos 
vacunados en el grupo de los controles que vivían en las áreas seleccionadas para la campaña de vacunación fue similar a la cobertura vacunal estimada en la población general, lo que garantiza la representatividad de nuestra muestra. En segundo lugar, hicimos un esfuerzo para cubrir todos los centros oficiales de tratamiento del cólera con el sistema de vigilancia reforzado donde se derivaban los casos sospechosos de cólera procedentes de las zonas con mayor riesgo de cólera en Lusaka.

\subsection{Encuesta de cobertura de la campaña de vacunación.}

En Lusaka se organizaron dos rondas de vacunación con OCV en 2016 con un número similar de dosis distribuidas en ambas rondas. La cobertura vacunal lograda en la segunda ronda (59\%) en las áreas objeto de la vacunación fue menor que la obtenida después de la primera ronda en abril de 2016 (68,6\%). Dentro del $36 \%$ de las personas vacunadas con una sola dosis de vacuna, el 30\% recibió esta dosis en abril de 2016 y el 70\% en diciembre de 2016. Eso sugiere que solo una parte de la población vacunada en abril de 2016 estaba presente en las áreas de vacunación en diciembre, limitando la posibilidad de obtener una cobertura vacunal alta con dos dosis. Estos resultados son muy relevantes teniendo en cuenta que ésta es la primera implementación de una segunda ronda de vacunación con retraso prolongado.

La cobertura vacunal con el esquema completo de dos dosis de vacuna fue del $33,9 \%$, encontrándo grandes diferencias de cobertura vacunal entre los menores (58,1\% en menores de 5 años y 59,5\% de 5 a 15 años) y los adultos (19,9\%), a pesar que este problema se detectó durante la campaña y se realizó una actividad de captación para reducir la brecha en la cobertura entre grupos de edad (107). Además, la cobertura vacunal en los hombres fue menor que en las mujeres, siendo esta diferencia mayor para al menos una dosis $(61,6 \%$ en los hombres y $75,7 \%$ en las mujeres). Este problema ya ha sido descrito en diferentes contextos como en Guinea, Tailandia y Bangladesh (137-139).

Ésta ha sido la primera campaña de vacunación con OCV que ha usado una pauta de vacunación con un intervalo tardío de ocho meses entre dosis. La mayoría de las 
encuestas de cobertura vacunal en campañas anteriores se focalizan en la estimación de la cobertura vacunal del esquema completo inmediatamente después de la implementación de la campaña estándar con dos dosis con un intervalo de dos semanas entre dosis (140-142), no abordado el cambio en la cobertura vacunal a lo largo del tiempo. Adicionalmente, la encuesta implementada en Lusaka en marzo de 2017 también permitió medir la proporción de personas en la población objeto para la campaña que habían sido vacunadas en la ronda de abril de 2016. A pesar del posible sesgo de información que puede haber afectado esta estimación, este porcentaje fue relativamente bajo, especialmente entre la población adulta, y plantea una cuestión importante sobre la necesidad de volver a vacunar para mantener un cierto nivel de cobertura vacunal a lo largo del tiempo. En este estudio, la cobertura con dos dosis (33.9\%) fue menor de lo esperado. Los movimientos poblacionales en estas comunidades urbanas son altos, probablemente relacionados con factores económicos, estacionales y laborales, especialmente en los municipios de Kanyama. Además, durante la campaña de vacunación se produjeron disturbios violentos no relacionados con la actividad de vacunación en algunos de los municipios seleccionados para la vacunación(143).

Un aspecto que podría mejorarse en futuras evaluaciones, considerando los posibles movimientos poblacionales como explicación parcial de los resultados, es incluir variables adicionales sobre cuando los individuos llegaron a las áreas objeto de la campaña y desde dónde, o por cuánto tiempo han vivído en dicha área para así caracterizar mejor los patrones de movilidad.

La segunda ronda tardía de vacunación permitió lograr una cobertura vacunal con al menos una dosis del 69,9\% justo antes del comienzo de la temporada de cólera de 2017 en Lusaka. Esta pauta de vacunación tardía podría haber sido una estrategia efectiva para alcanzar un buen nivel de protección antes de la temporada de cólera, debido a la protección similar a corto plazo tanto con una como con dos dosis; tal y como vemos tanto en nuestro estudio y en anteriores $(89,90,92,144)$ 
Las estimaciones globales tuvieron una precisión adecuada ya que logramos el tamaño muestral deseado. Sin embargo, la precisión de las estimaciones por municipio no fue óptima, especialmente en Bauleni. Considerando la alta heterogeneidad espacial observada por municipio, en el futuro se debería considerar un muestreo estratificado por unidades geográficas más pequeñas.

Una limitación adicional es el uso de la cobertura vacunal y otras medidas cuantitativas para evaluar la aceptabilidad de la campaña. La evaluación cualitativa podría enriquecer la información que tenemos sobre el conocimiento, las percepciones y las barreras que limitan el desempeño de las actividades de vacunación. Se necesitan mediciones cualitativas para comprender el mejor enfoque para vacunar a las comunidades móviles, como en las áreas urbanas seleccionadas en Lusaka.

La principal limitación de este estudio es el alto porcentaje de individuos vacunados sin carné vacunal, a pesar del breve intervalo entre la campaña de vacunación (abril 2016 y diciembre de 2016) y de las encuestas de cobertura vacunal (mayo de 2016 y marzo de 2017). En cuanto a la primera ronda de vacunación, esta situación pudo ser probablemente debida a la mala calidad del papel utilizado para impresión de los carnés. Los carnés vacunales se agotaron durante la segunda ronda de vacunación. Aunque se recomendó traer los carnés de la ronda anterior, varias personas reportaron haber olvidado o extraviado sus carnés. Cuando se agotaron los carnés de vacunación, se dieron octavillas de papel como documento de vacunación. Esto podría ser una explicación adicional de la baja retención del carné. De todas formas, la corta demora entre la campaña y el reclutamiento de los participantes en la encuesta posiblemente haya controlado el riesgo de sesgo de información del estado vacunal. A pesar de esto, la baja retención del carné vacunal nos dificulta estar seguros sobre la cobertura vacunal.

Cabe la posibilidad que un sesgo de memoria o información haya estado en juego debido al intervalo de tiempo de 11 meses entre la primera ronda y la encuesta de marzo de 2017, lo que podría haber llevado a subestimar la cobertura con dos dosis de vacuna. Pudiera ser que las personas que no tomaron la dosis de vacuna 
en diciembre de 2016 hayan tenido más dificultad para recordar si habían recibido la dosis de la ronda de abril. Esto podría explicar las grandes discrepancias en la cobertura de la primera ronda entre los adultos (y especialmente en los hombres) entre las encuestas de 2016 y 2017 (41,3\% de cobertura en los hombres en la encuesta de 2016 y 14,7\% en la encuesta de 2017). 
CONCLUSIONES

Y RECOMENDACIONES 



\section{CONCLUSIONES Y RECOMENDACIONES}

\subsection{Revisión sistemática y metaanálisis}

- Las últimas tres décadas de evidencia científica apuntan a que las vacunas orales frente al cólera son una herramienta segura, efectiva e importante para combatir la infección por cólera.

- Dos dosis de vacuna oral frente al cólera proporcionan una protección de al menos 3 años.

- Una dosis de vacuna oral frente al cólera proporciona al menos una protección a corto plazo, lo que tiene implicaciones importantes para el manejo de brotes.

- Existe una relación directa entre la mediana de edad de los casos reclutados en los estudios y la estimación del nivel de protección conferida por la vacuna.

- Las vacunas orales frente al cólera son una herramienta efectiva para su control. Si bien la vacunación por sí sola probablemente no llevará a la eliminación, puede proporcionar una importante solución provisional mientras se proporciona una mejor infraestructura de agua, saneamiento y atención médica a las poblaciones vulnerables.

- Son necesarios más estudios para estimar la eficacia vacunal por grupo de edad, especialmente en los menores de 5 años. 


\subsection{Efectividad vacunal a corto plazo con una dosis de vacuna}

- Nuestro estudio confirma que una dosis de ShancholTM puede ser una herramienta eficaz para el control de epidemias de cólera, si las campañas se implementan a tiempo, incluyendo en áreas con poca o ninguna exposición reciente al cólera.

- Los tres diseños empleados en nuestro estudio proporcionan estimaciones similares de protección alta a corto plazo para una dosis de vacuna oral frente al cólera.

- Las estimaciones provenientes de los estudios de caso-cohorte y de casos y controles pareado son las más precisas que el test negativo.

- En el estudio de caso-cohorte el poder estadísco se maximiza al poder establecer una población expuesta y no expuesta a la que se le añaden los nuevos casos incidentes.

- En el estudio de casos y controles pareado el poder estadisto se aumenta gracias a la eficiencia al combinar hasta cinco controles comunitarios para cada caso por grupo de edad, vecindario y tiempo.

- Los diseños alternativos, el test negativo de casos y controles y el casocohorte, obtuvieron estimaciones similares de eficacia vacunal que el diseño de casos y controles pareados, con la ventaja de tener un mejor control sobre sesgo de comportamiento de búsqueda de atención médica y detectar posibles efectos indirectos de la vacuna.

- El test negativo de casos y controles es una buena alternativa en situaciones de emergencia, especialmente si el reclutamiento de los controles está comprometido (por ejemplo, por razones de seguridad). 
- Los diseño de casos y controles y caso-cohorte son una opción adecuada cuando hay pocos casos después de la campaña de vacunación para asi mejorar el poder estadístico del estudio.

- Dado que altos niveles de protección a corto plazo podrían ser determinantes del impacto de cualquier campaña de vacunación, nuestros resultados apoyan el uso del régimen de una dosis de OCV en la respuesta a brotes de infección por cólera.

- Nuestros hallazgos aportan una información clave y esencial para mejorar las recomendaciones actuales de la OMS para el uso racional de la vacuna frente al cólera en entornos epidémicos.

- Se necesitan más estudios para establecer la duración de la protección proporcionada por el esquema vacunal con dosis única en menores y personas no expuestas previamente al cólera, así como el intervalo apropiado para la administración de una segunda dosis para incrementar la duración de la protección de la primera dosis.

\subsection{Cobertura vacunal de la campaña con una pauta de dos dosis de vacuna administradas de forma tardía}

- La cobertura con al menos una dosis de OCV fue adecuada para evitar un brote en las áreas vacunadas durante la temporada de lluvias de 2017 (enero a junio).

- La alta movilidad de la población sugiere que la cobertura vacunal podría disminuir con el tiempo, especialmente en los adultos, donde los niveles de cobertura vacunal son más bajos. 
- En caso de persistencia de riesgo de transmisión en Lusaka, campañas de vacunación adicionales podrían ser necesarias para mantener la protección a lo largo del tiempo.

- En contextos donde no es posible la vacunanción con dos dosis de OCV con la pauta de dos semanas que estipula la ficha técnica, como por ejemplo en una situación epidémica donde es necesaria una respuesta rápida y reactiva existiendo una reserva limitada de vacunas, es pertinente la estrategia de administrar la segunda dosis de forma tardía para el control del brote (en términos de reducción de la morbilidad, mortalidad y transmisión) con un mayor número de dosis en primera instancia e incrementar la protección de la vacuna a largo plazo.

- Las campañas vacunales anuales previas a la temporada de cólera en zonas con movilidad poblacional alta podrían ser una estrategia eficaz para reducir el riesgo de brotes en lugares con alto riesgo de transmisión del cólera.

- Se recomienda desarrollar estrategias específicas para llegar mejor a la población adulta, especialmente a los hombres, para aumentar la cobertura vacunal en los mayores de 15 años.

- Se necesita más evidencia para establecer el intervalo máximo óptimo de la segunda dosis y las variaciones en los diferentes contextos y en los patrones de movilidad. 
CONCLUSIONS

AND RECOMENDATIONS 



\section{CONCLUSIONS AND RECOMENDATIONS}

\subsection{Systematic review and meta-analysis of killed whole-cell oral cholera vaccines}

- Evidence from the past three decades points towards oral cholera vaccines being a safe, effective, and important tool to fight cholera.

- Oral cholera vaccines administered under the standard two-dose regimen provide a moderate to high level of protection for at least 3 years.

- A one-dose regimen provides significant short-term protection, which has important implications for outbreak management.

- There is a direct association between the median age of the cases recruited in the studies and the estimate of the level of protection conferred by the vaccine.

- More work is needed to refine estimates of the differential protection by age, especially in children under 5 years.

- Oral cholera vaccines are an effective tool for cholera control. Although vaccination alone will probably not lead to elimination, it can provide an important stopgap while improved water, sanitation, and health-care infrastructure are provided to vulnerable populations.

\subsection{Short-term effectiveness of a single-dose of OCV}

- This study confirms that one dose of ShancholTM could be an effective tool to control cholera during outbreaks, if campaigns are timely implemented, even in areas with little to no recent exposure to cholera. 
- The three different designs used provide similar estimates of high-level short-term protection of one dose of oral cholera vaccine.

- Estimates from the matched case-control design are more precise because we maximized statistical power and efficiency by matching up to five community controls to each case by age group, sex, neighborhood and calendar time.

- Alternative study designs (test-negative case-control and case-cohort) yielded similar estimates of vaccine effectiveness as matched case-control design design with the advantage of better controlling the healthcare seeking behavior bias and allowing the detection of eventual indirect effects of the vaccine.

- The test-negative case-control is a good alternative in emergency situations, especially if community controls recruitment is compromised (e.g. security reasons).

- Case-cohort design is an adequate option when there are few cases after vaccination to increase the study power.

- Since high levels of short-term protection could be determinants of the impact of any vaccination campaign, our results support the use of one dose regimens to improve responses during a cholera outbreak.

- Our findings provided key and essential information to improve WHO recommendations for the rational use of cholera vaccines in epidemic settings.

- Additional work is needed to determine the protection provided by a singledose in young children and persons not previously exposed to cholera and the optimal dosing interval for the second dose, which should increase the 
duration of vaccine protection among individuals primed with a one dose regimen.

\subsection{Oral cholera vaccination campaign coverage survey}

- The delayed second dose was adequate to prevent an outbreak in vaccinated areas during the 2017 rainy season (January to June)

- High population mobility suggests that the vaccination coverage may decrease over time, especially in adults, where vaccine coverage levels are lower.

- In case of persistence of risk of cholera transmission in Lusaka, additional vaccination campaigns may be necessary to maintain a certain level of vaccine coverage over time.

- In situations where it is not possible to vaccinate with two doses of oral cholera vaccine in a normal two-weeks schedule, as in epidemic situation where a prompt and reactive response is necessary and where there is a global shortage of vaccines, a strategy of administering a delayed second dose is pertinent. It allows for urgently controlling the outbreak (in terms of reducing morbidity, mortality and transmission) with a higher number of doses available together with increasing the vaccine protection in the longer term at a later step, once adequate doses of vaccine become available for the delayed second round.

- For highly mobile populations, where the vaccination coverage of mass vaccination campaigns might drop relatively quickly over time, annual preventive campaigns before the cholera season starts might be a more efficient strategy than two doses campaigns to effectively reduce the risk of outbreaks. 
- It is recommended to develop specific strategies to better reach the adult population, especially men, to increase vaccination coverage in those over 15 years.

- More evidence is needed to establish the optimal maximum interval between the two doses, also taking into account variations in different settings and mobility patterns. 
BIBLIOGRAFÍA 



\section{BIBLIOGRAFÍA}

1. David L. Heymann. Control of Communicable Diseases Manual. 20th ed. APHA Press; $12 / 14.729$ p.

2. Snow J. On the mode of communication of cholera. :32.

3. Nelson EJ, Harris JB, Morris JG, Calderwood SB, Camilli A. Cholera transmission: the host, pathogen and bacteriophage dynamic. Nat Rev Microbiol. 2009 Oct;7(10):693-702.

4. Clemens J, Shin S, Sur D, Nair GB, Holmgren J. New-generation vaccines against cholera. Nat Rev Gastroenterol Hepatol. 2011 Nov 8;8(12):701-10.

5. Sack GH, Pierce NF, Hennessey KN, Mitra RC, Sack RB, Mazumder DN. Gastric acidity in cholera and noncholera diarrhoea. Bull World Health Organ. 1972;47(1):31-6.

6. Clemens JD, Sack DA, Harris JR, Khan MR, Chakraborty J, Chowdhury S, et al. Breast feeding and the risk of severe cholera in rural Bangladeshi children. Am J Epidemiol. 1990 Mar;131(3):400-11.

7. Sircar BK, Dutta P, De SP, Sikdar SN, Deb BC, Pal SC, et al. ABO blood group distributions in diarrhoea cases including cholera in Calcutta. Ann Hum Biol. 1981 Jun;8(3):289-91.

8. Cabezas AR. Anotaciones descriptivas del último brote epidémico de cólera en España (1979) [Internet]. Isla de Arriarán: revista cultural y científica. 2000 [cited 2018 Nov 22]. Available from: https://dialnet.unirioja.es/servlet/articulo?codigo=2043345

9. Ali M, Nelson AR, Lopez AL, Sack DA. Updated global burden of cholera in endemic countries. PLoS Negl Trop Dis. 2015;9(6):e0003832.

10. Li F, Du P, Li B, Ke C, Chen A, Chen J, et al. Distribution of virulenceassociated genes and genetic relationships in non-01/0139 Vibrio cholerae aquatic isolates from China. Appl Environ Microbiol. 2014 Aug;80(16):4987-92.

11. Bhattacharya MK, Bhattacharya SK, Garg S, Saha PK, Dutta D, Nair GB, et al. Outbreak of Vibrio cholerae non-01 in India and Bangladesh. Lancet Lond Engl. 1993 May 22;341(8856):1346-7.

12. Large epidemic of cholera-like disease in Bangladesh caused by Vibrio cholerae 0139 synonym Bengal. Cholera Working Group, International Centre for Diarrhoeal Diseases Research, Bangladesh. Lancet Lond Engl. 1993 Aug 14;342(8868):387-90.

13. Nair GB, Bhattacharya SK, Deb BC. Vibrio cholerae 0139 Bengal: the eighth pandemic strain of cholera. Indian J Public Health. 1994 Jun;38(2):33-6.

14. WHO. Cholera vaccines: WHO position paper - August 2017 [Internet]. $2017 \quad$ Aug. Available from: http://apps.who.int/iris/bitstream/10665/258763/1/WER9234.pdf?ua=1

15. PNUD. Objetivos de desarrollo sostenible [Internet]. Available from: https://www.undp.org/content/undp/es/home/sustainable-developmentgoals.html

16. Kaper JB, Morris JG, Levine MM. Cholera. Clin Microbiol Rev. 1995 Jan;8(1):48-86. 
17. Waldor MK, Mekalanos JJ. Lysogenic conversion by a filamentous phage encoding cholera toxin. Science. 1996 Jun 28;272(5270):1910-4.

18. Orata FD, Keim PS, Boucher Y. The 2010 Cholera Outbreak in Haiti: How Science Solved a Controversy. PLoS Pathog [Internet]. 2014 Apr 3 [cited 2019 Mar 12];10(4). Available from: https://www.ncbi.nlm.nih.gov/pmc/articles/PMC3974815/

19. Sánchez J, Holmgren J. Cholera toxin structure, gene regulation and pathophysiological and immunological aspects. Cell Mol Life Sci CMLS. 2008 May;65(9):1347-60.

20. Faruque SM, Tam VC, Chowdhury N, Diraphat P, Dziejman M, Heidelberg JF, et al. Genomic analysis of the Mozambique strain of Vibrio cholerae 01 reveals the origin of El Tor strains carrying classical CTX prophage. Proc Natl Acad Sci U S A. 2007 Mar 20;104(12):5151-6.

21. Kim EJ, Lee D, Moon SH, Lee CH, Kim SJ, Lee JH, et al. Molecular insights into the evolutionary pathway of Vibrio cholerae 01 atypical El Tor variants. PLoS Pathog. 2014 Sep;10(9):e1004384.

22. Safa A, Nair GB, Kong RYC. Evolution of new variants of Vibrio cholerae 01. Trends Microbiol. 2010 Jan;18(1):46-54.

23. Waldor MK, Rubin EJ, Pearson GD, Kimsey H, Mekalanos JJ. Regulation, replication, and integration functions of the Vibrio cholerae CTXphi are encoded by region RS2. Mol Microbiol. 1997 Jun;24(5):917-26.

24. Mutreja A, Kim DW, Thomson NR, Connor TR, Lee JH, Kariuki S, et al. Evidence for several waves of global transmission in the seventh cholera pandemic. Nature. 2011 Sep;477(7365):462-5.

25. Sack DA, Sack RB, Nair GB, Siddique AK. Cholera. Lancet Lond Engl. 2004 Jan 17;363(9404):223-33.

26. Nair GB, Qadri F, Holmgren J, Svennerholm A-M, Safa A, Bhuiyan NA, et al. Cholera due to altered El Tor strains of Vibrio cholerae 01 in Bangladesh. J Clin Microbiol. 2006 Nov;44(11):4211-3.

27. Ansaruzzaman M, Bhuiyan NA, Nair GB, Sack DA, Lucas M, Deen JL, et al. Cholera in Mozambique, Variant of Vibrio cholerae. Emerg Infect Dis. 2004 Nov;10(11):2057-9.

28. Das B, Halder K, Pal P, Bhadra RK. Small chromosomal integration site of classical CTX prophage in Mozambique Vibrio cholerae 01 biotype El Tor strain. Arch Microbiol. 2007 Dec;188(6):677-83.

29. al KE et. Molecular insights into the evolutionary pathway of Vibrio cholerae 01 atypical El Tor variants. - PubMed - NCBI [Internet]. [cited 2019 Feb 28]. Available from: https://www.ncbi.nlm.nih.gov/pubmed/25233006

30. Chin C-S, Sorenson J, Harris JB, Robins WP, Charles RC, Jean-Charles RR, et al. The origin of the Haitian cholera outbreak strain. N Engl J Med. 2011 Jan 6;364(1):33-42.

31. Safa A, Sultana J, Cam PD, Mwansa JC, Kong RYC. Vibrio cholerae 01 Hybrid El Tor Strains, Asia and Africa. Emerg Infect Dis. 2008 Jun;14(6):987-8.

32. Johnson JA, Salles CA, Panigrahi P, Albert MJ, Wright AC, Johnson RJ, et al. Vibrio cholerae 0139 synonym bengal is closely related to Vibrio cholerae El Tor but has important differences. Infect Immun. 1994 May;62(5):2108-10.

33. Lönnroth I, Holmgren J. Subunit structure of cholera toxin. J Gen Microbiol. 1973 Jun;76(2):417-27.

34. Vanden Broeck D, Horvath C, De Wolf MJS. Vibrio cholerae: cholera toxin. Int 
J Biochem Cell Biol. 2007;39(10):1771-5.

35. Zhang RG, Scott DL, Westbrook ML, Nance S, Spangler BD, Shipley GG, et al. The three-dimensional crystal structure of cholera toxin. J Mol Biol. 1995 Aug 25;251(4):563-73.

36. Merritt EA, Sarfaty S, van den Akker F, L'Hoir C, Martial JA, Hol WG. Crystal structure of cholera toxin B-pentamer bound to receptor GM1 pentasaccharide. Protein Sci Publ Protein Soc. 1994 Feb;3(2):166-75.

37. Olivier V, Haines GK, Tan Y, Satchell KJF. Hemolysin and the Multifunctional Autoprocessing RTX Toxin Are Virulence Factors during Intestinal Infection of Mice with Vibrio cholerae El Tor 01 Strains. Infect Immun. 2007 Oct;75(10):503542.

38. Carrada-Bravo T. [The immunology of cholera and the molecular biology of cholera toxin. Recent progress and future perspectives]. Rev Alerg Mex Tecamachalco Puebla Mex 1993. 1994 Jun;41(3):69-76.

39. Clemens JD, Nair GB, Ahmed T, Qadri F, Holmgren J. Cholera. Lancet Lond Engl. 2017 Sep 23;390(10101):1539-49.

40. Chiappelli F, Khakshooy A, Balenton N. Clinical Immunology of Cholera Current Trends and Directions for Future Advancement. Bioinformation. 2017;13(10):352-5.

41. Saha D, LaRocque RC, Khan AI, Harris JB, Begum YA, Akramuzzaman SM, et al. Incomplete correlation of serum vibriocidal antibody titer with protection from Vibrio cholerae infection in urban Bangladesh. J Infect Dis. 2004 Jun 15;189(12):2318-22.

42. Bhuiyan TR, Lundin SB, Khan AI, Lundgren A, Harris JB, Calderwood SB, et al. Cholera caused by Vibrio cholerae 01 induces $T$-cell responses in the circulation. Infect Immun. 2009 May;77(5):1888-93.

43. Levine MM, Black RE, Clements ML, Cisneros L, Nalin DR, Young CR. Duration of infection-derived immunity to cholera. J Infect Dis. 1981 Jun;143(6):818-20.

44. Harris AM, Bhuiyan MS, Chowdhury F, Khan AI, Hossain A, Kendall EA, et al. Antigen-specific memory B-cell responses to Vibrio cholerae 01 infection in Bangladesh. Infect Immun. 2009 Sep;77(9):3850-6.

45. Glass RI, Becker S, Huq MI, Stoll BJ, Khan MU, Merson MH, et al. Endemic cholera in rural Bangladesh, 1966-1980. Am J Epidemiol. 1982 Dec;116(6):959-70. 46. Patel SM, Rahman MA, Mohasin M, Riyadh MA, Leung DT, Alam MM, et al. Memory B cell responses to Vibrio cholerae 01 lipopolysaccharide are associated with protection against infection from household contacts of patients with cholera in Bangladesh. Clin Vaccine Immunol CVI. 2012 Jun;19(6):842-8.

47. Holmgren J, Svennerholm AM. Mechanisms of disease and immunity in cholera: a review. J Infect Dis. 1977 Aug;136 Suppl:S105-112.

48. Glass RI, Svennerholm AM, Khan MR, Huda S, Huq MI, Holmgren J. Seroepidemiological studies of El Tor cholera in Bangladesh: association of serum antibody levels with protection. J Infect Dis. 1985 Feb;151(2):236-42.

49. Wasserman SS, Losonsky GA, Noriega F, Tacket CO, Castañeda E, Levine MM. Kinetics of the vibriocidal antibody response to live oral cholera vaccines. Vaccine. 1994 Aug;12(11):1000-3.

50. Albert MJ, Alam K, Ansaruzzaman M, Qadri F, Sack RB. Lack of crossprotection against diarrhea due to Vibrio cholerae 0139 (Bengal strain) after oral immunization of rabbits with V. cholerae 01 vaccine strain CVD103-HgR. J Infect 
Dis. 1994 Jan;169(1):230-1.

51. Clemens JD, van Loon F, Sack DA, Rao MR, Ahmed F, ChakrabortY J, et al. Biotype as determinant of natural immunising effect of cholera. Lancet Lond Engl. 1991 Apr 13;337(8746):883-4.

52. Ali M, Emch M, Park JK, Yunus M, Clemens J. Natural cholera infectionderived immunity in an endemic setting. J Infect Dis. 2011 Sep 15;204(6):912-8.

53. Pollitzer R, Burrows W. Cholera studies. IV. Problems in immunology. Bull World Health Organ. 1955;12(6):945-1107.

54. Cash RA, Music SI, Libonati JP, Craig JP, Pierce NF, Hornick RB. Response of man to infection with Vibrio cholerae. II. Protection from illness afforded by previous disease and vaccine. J Infect Dis. 1974 Oct;130(4):325-33.

55. Bornside GH. Waldemar Haffkine's cholera vaccines and the FerranHaffkine priority dispute. J Hist Med Allied Sci. 1982 Dec;37(4):399-422.

56. Mukerjee S. Preliminary studies on the development of a live oral vaccine for anti-cholera immunization. Bull World Health Organ. 1963;29(6):753-66.

57. Benenson AS, Joseph PR, Oseasohn RO. Cholera vaccine field trials in east Pakistan. 1. Reaction and antigenicity studies. Bull World Health Organ. 1968;38(3):347-57.

58. Freter R. Comparison of immune mechanisms in various experimental models of cholera. Bull World Health Organ. 1964;31(6):825-34.

59. Antibody response in the intestinal secretions of volunteers immunized with various cholera vaccines. - Abstract - Europe PMC [Internet]. [cited 2020 Mar 15]. Available from: https://europepmc.org/article/pmc/pmc2366383

60. Svennerholm AM, Jertborn M, Gothefors L, Karim AM, Sack DA, Holmgren J. Mucosal antitoxic and antibacterial immunity after cholera disease and after immunization with a combined B subunit-whole cell vaccine. J Infect Dis. 1984 Jun;149(6):884-93.

61. Richie EE, Punjabi NH, Sidharta YY, Peetosutan KK, Sukandar MM, Wasserman SS, et al. Efficacy trial of single-dose live oral cholera vaccine CVD 103HgR in North Jakarta, Indonesia, a cholera-endemic area. Vaccine. 2000 May 8;18(22):2399-410.

62. Bhattacharya SK, Sur D, Ali M, Kanungo S, You YA, Manna B, et al. 5 year efficacy of a bivalent killed whole-cell oral cholera vaccine in Kolkata, India: a cluster-randomised, double-blind, placebo-controlled trial. Lancet Infect Dis. 2013 Dec;13(12):1050-6.

63. Ali M, Emch M, von Seidlein L, Yunus M, Sack DA, Rao M, et al. Herd immunity conferred by killed oral cholera vaccines in Bangladesh: a reanalysis. Lancet Lond Engl. 2005 Jul 2;366(9479):44-9.

64. Lewis DJ, Gilks CF, Ojoo S, Castello-Branco LR, Dougan G, Evans MR, et al. Immune response following oral administration of cholera toxin $B$ subunit to HIV1-infected UK and Kenyan subjects. AIDS Lond Engl. 1994 Jun;8(6):779-85.

65. Clemens JD, Sack DA, Harris JR, Chakraborty J, Khan MR, Stanton BF, et al. Field trial of oral cholera vaccines in Bangladesh. Lancet Lond Engl. 1986 Jul 19;2(8499):124-7.

66. van Loon FPL, Clemens JD, Chakraborty J, Rao MR, Kay BA, Sack DA, et al. Field trial of inactivated oral cholera vaccines in Bangladesh: results from 5 years of follow-up. Vaccine. 1996 Feb 1;14(2):162-6.

67. Clemens JD, Sack DA, Chakraborty J, Rao MR, Ahmed F, Harris JR, et al. Field trial of oral cholera vaccines in Bangladesh: evaluation of anti-bacterial and anti- 
toxic breast-milk immunity in response to ingestion of the vaccines. Vaccine. 1990 Oct;8(5):469-72.

68. Clemens JD, Sack DA, Harris JR, Chakraborty J, Khan MR, Stanton BF, et al. Impact of B subunit killed whole-cell and killed whole-cell-only oral vaccines against cholera upon treated diarrhoeal illness and mortality in an area endemic for cholera. Lancet Lond Engl. 1988 Jun 18;1(8599):1375-9.

69. Sanchez JL, Vasquez B, Begue RE, Meza R, Castellares G, Cabezas C, et al. Protective efficacy of oral whole-cell/recombinant-B-subunit cholera vaccine in Peruvian military recruits. Lancet Lond Engl. 1994 Nov 5;344(8932):1273-6.

70. Clemens JD, Sack DA, Ivanoff B. Misleading negative findings in a field trial of killed, oral cholera vaccine in Peru. J Infect Dis. 2001 Apr 15;183(8):1306-9.

71. Taylor DN, Cárdenas V, Sanchez JL, Bégué RE, Gilman R, Bautista C, et al. Two-year study of the protective efficacy of the oral whole cell plus recombinant $B$ subunit cholera vaccine in Peru. J Infect Dis. 2000 May;181(5):1667-73.

72. Lucas MES, Deen JL, von Seidlein L, Wang X-Y, Ampuero J, Puri M, et al. Effectiveness of mass oral cholera vaccination in Beira, Mozambique. N Engl J Med. 2005 Feb 24;352(8):757-67.

73. Khatib AM, Ali M, von Seidlein L, Kim DR, Hashim R, Reyburn R, et al. Effectiveness of an oral cholera vaccine in Zanzibar: findings from a mass vaccination campaign and observational cohort study. Lancet Infect Dis. 2012 Nov;12(11):837-44.

74. Thiem VD, Deen JL, von Seidlein L, Canh DG, Anh DD, Park J-K, et al. Longterm effectiveness against cholera of oral killed whole-cell vaccine produced in Vietnam. Vaccine. 2006 May 15;24(20):4297-303.

75. Anh DD, Lopez AL, Thiem VD, Grahek SL, Duong TN, Park JK, et al. Use of oral cholera vaccines in an outbreak in Vietnam: a case control study. PLoS Negl Trop Dis. 2011;5(1):e1006.

76. Trach DD, Cam PD, Ke NT, Rao MR, Dinh D, Hang PV, et al. Investigations into the safety and immunogenicity of a killed oral cholera vaccine developed in Viet Nam. Bull World Health Organ. 2002;80(1):2-8.

77. Mahalanabis D, Lopez AL, Sur D, Deen J, Manna B, Kanungo S, et al. A Randomized, Placebo-Controlled Trial of the Bivalent Killed, Whole-Cell, Oral Cholera Vaccine in Adults and Children in a Cholera Endemic Area in Kolkata, India. PLoS ONE [Internet]. 2008 Jun 4 [cited 2018 Apr 10];3(6). Available from: https://www.ncbi.nlm.nih.gov/pmc/articles/PMC2396289/

78. Sur D, Kanungo S, Sah B, Manna B, Ali M, Paisley AM, et al. Efficacy of a LowCost, Inactivated Whole-Cell Oral Cholera Vaccine: Results from 3 Years of FollowUp of a Randomized, Controlled Trial. PLoS Negl Trop Dis. 2011 Oct 18;5(10):e1289.

79. Ali M, Sur D, You YA, Kanungo S, Sah B, Manna B, et al. Herd protection by a bivalent killed whole-cell oral cholera vaccine in the slums of Kolkata, India. Clin Infect Dis Off Publ Infect Dis Soc Am. 2013 Apr;56(8):1123-31.

80. Martin S, Lopez AL, Bellos A, Deen J, Ali M, Alberti K, et al. Post-licensure deployment of oral cholera vaccines: a systematic review. Bull World Health Organ. 2014 Dec 1;92(12):881-93.

81. EuBiologics Co. Ltd. Euvichol ${ }^{\circledR}$ (Oral Cholera Vaccine) [Internet]. 2016. Available from: http://eubiologics.com/en/products/Euvichol_insert.pdf

82. Baik YO, Choi SK, Olveda RM, Espos RA, Ligsay AD, Montellano MB, et al. A randomized, non-inferiority trial comparing two bivalent killed, whole cell, oral 
cholera vaccines (Euvichol vs Shanchol) in the Philippines. Vaccine. 2015 Nov 17;33(46):6360-5.

83. Lopez AL, Gonzales MLA, Aldaba JG, Nair GB. Killed oral cholera vaccines: history, development and implementation challenges. Ther Adv Vaccines. 2014 Sep;2(5):123-36.

84. Chen WH, Cohen MB, Kirkpatrick BD, Brady RC, Galloway D, Gurwith M, et al. Single-dose Live Oral Cholera Vaccine CVD 103-HgR Protects Against Human Experimental Infection With Vibrio cholerae 01 El Tor. Clin Infect Dis Off Publ Infect Dis Soc Am. 2016 01;62(11):1329-35.

85. Central Statistical Office. Lusaka. Zambia in figures 2018. [Internet]. Available from: http://zambia.opendataforafrica.org/ZMPHC2015/populationand-demographic-projections-2011-2035

86. ZambiaCountryProfile2011 [Internet]. [cited 2016 Oct 28]. Available from: http://www.who.int/cholera/countries/ZambiaCountryProfile2011.pdf?ua=1

87. Olu O, Babaniyi O, Songolo P, Matapo B, Chizema E, Kapin'a-Kanyanga M, et al. Cholera epidemiology in zambia from 2000 to 2010: implications for improving cholera prevention and control strategies in the country. East Afr Med J. 2013 Oct;90(10):324-31.

88. Ivers LC, Hilaire IJ, Teng JE, Almazor CP, Jerome JG, Ternier R, et al. Effectiveness of reactive oral cholera vaccination in rural Haiti: a case-control study. Lancet Glob Health. 2015 Mar;3(3):e162-8.

89. Luquero FJ, Grout L, Ciglenecki I, Sakoba K, Traore B, Heile M, et al. Use of Vibrio cholerae vaccine in an outbreak in Guinea. N Engl J Med. 2014 May 29;370(22):2111-20.

90. Azman AS, Parker LA, Rumunu J, Tadesse F, Grandesso F, Deng LL, et al. Effectiveness of one dose of oral cholera vaccine in response to an outbreak: a case-cohort study. Lancet Glob Health. 2016 Nov;4(11):e856-63.

91. Azman AS, Luquero FJ, Ciglenecki I, Grais RF, Sack DA, Lessler J. The Impact of a One-Dose versus Two-Dose Oral Cholera Vaccine Regimen in Outbreak Settings: A Modeling Study. PLoS Med. 2015 Aug;12(8):e1001867.

92. Qadri F, Wierzba TF, Ali M, Chowdhury F, Khan AI, Saha A, et al. Efficacy of a Single-Dose, Inactivated Oral Cholera Vaccine in Bangladesh. N Engl J Med. 2016 May 5;374(18):1723-32.

93. WHO | Potential use of oral cholera vaccines in emergency situations. Report of a WHO meeting. Geneva, Switzerland, 12-13 May 1999 [Internet]. WHO. [cited 2019 Mar 14]. Available from: https://www.who.int/topics/cholera/publications/WHO_CDS_CSR_EDC_99_4/en/ 94. a64_rec1-en.pdf [Internet]. [cited 2019 Mar 14]. Available from: http://apps.who.int/gb/ebwha/pdf_files/wha64-rec1/a64_rec1-en.pdf

95. Oral Cholera Vaccine stockpile for cholera emergency response. [Internet]. WHO; 2013.2 Available from: http://www.who.int/cholera/vaccines/Briefing_OCV_stockpile.pdf

96. World Health Organization, Geneva. International Coordinating Group (ICG) on vaccine provision for cholera [Internet]. Available from: http://www.who.int/csr/disease/icg/cholera/en/

97. WHO | The Global Task Force on Cholera Control [Internet]. [cited 2019 Mar 14]. Available from: https://www.who.int/cholera/task_force/en/

98. Vaccination against cholera in Juba - The Lancet Infectious Diseases [Internet]. [cited 2019 Mar 16]. Available from: 
https://www.thelancet.com/journals/laninf/article/PIIS1473-3099(17)30189$5 /$ fulltext

99. Fast rollout of cholera vaccines for people in need in Mozambique Mozambique [Internet]. ReliefWeb. [cited 2020 Jan 9]. Available from: https://reliefweb.int/report/mozambique/fast-rollout-cholera-vaccines-peopleneed-mozambique

100. Deployments from the oral cholera vaccine stockpile, 2013-2017. Releve Epidemiol Hebd. 2017 11;92(32):437-42.

101. Cochrane Handbook for Systematic Reviews of Interventions [Internet]. [cited 2019 Jun 4]. Available from: https://handbook-5-1.cochrane.org/

102. Sidik K, Jonkman JN. A comparison of heterogeneity variance estimators in combining results of studies. Stat Med. 2007 Apr 30;26(9):1964-81.

103. Viechtbauer W. Conducting Meta-Analyses in R with the metafor Package. J Stat Softw. 2010 Aug 5;36(1):1-48.

104. Raudenbush SW. Magnitude of Teacher Expectancy Effects on Pupil IQ as a Function of the Credibility of Expectancy Induction: A Synthesis of Findings from 18 Experiments. J Educ Psychol. 1984;76(1):85-97.

105. Bi Q, Ferreras E, Pezzoli L, Legros D, Ivers LC, Date K, et al. Protection against cholera from killed whole-cell oral cholera vaccines: a systematic review and meta-analysis. Lancet Infect Dis. 2017 Oct;17(10):1080-8.

106. Marc Poncin, Gideon Zulu, Caroline Voute, Eva Ferreras, Clara Mbwili Muleya, Kennedy Malama, et al. Implementation research: the feasibility of a reduced-dose mass cholera vaccination campaign in response to an outbreak in Lusaka, Zambia. Bull World Health Organ. 2018 Feb;96(2):86-93.

107. Poncin M, Zulu G, Voute C, Ferreras E, Muleya CM, Malama K, et al. Implementation research: reactive mass vaccination with single-dose oral cholera vaccine, Zambia. Bull World Health Organ. 2018 Feb 1;96(2):86-93.

108. Franke MF, Jerome JG, Matias WR, Ternier R, Hilaire IJ, Harris JB, et al. Comparison of two control groups for estimation of oral cholera vaccine effectiveness using a case-control study design. Vaccine. 2017 13;35(43):5819-27. 109. Ali M, You YA, Sur D, Kanungo S, Kim DR, Deen J, et al. Validity of the estimates of oral cholera vaccine effectiveness derived from the test-negative design. Vaccine. 2016 Jan 20;34(4):479-85.

110. Pearson AL, Rzotkiewicz A, Zwickle A. Using remote, spatial techniques to select a random household sample in a dispersed, semi-nomadic pastoral community: utility for a longitudinal health and demographic surveillance system. Int J Health Geogr. 2015 Nov 14;14:33.

111. Isolation of Vibrio cholerae from Fecal Specimens - laboratory-methods-forthe-diagnosis-of-vibrio-cholerae-chapter-4.pdf [Internet]. [cited 2016 Oct 28]. Available from: https://www.cdc.gov/cholera/pdf/laboratory-methods-for-thediagnosis-of-vibrio-cholerae-chapter-4.pdf

112. Hoshino K, Yamasaki S, Mukhopadhyay AK, Chakraborty S, Basu A, Bhattacharya SK, et al. Development and evaluation of a multiplex PCR assay for rapid detection of toxigenic Vibrio cholerae 01 and 0139. FEMS Immunol Med Microbiol. 1998 Mar;20(3):201-7.

113. Barlow WE, Ichikawa L, Rosner D, Izumi S. Analysis of case-cohort designs. J Clin Epidemiol. 1999 Dec;52(12):1165-72.

114. Applied Survival Analysis: Regression Modeling of Time-to-Event Data, Second Edition | Request PDF [Internet]. ResearchGate. [cited 2019 Mar 8]. 
Available

from:

https://www.researchgate.net/publication/230140138_Applied_Survival_Analysi

s_Regression_Modeling_of_Time-to-Event_Data_Second_Edition

115. Lee KJ, Carlin JB. Multiple imputation for missing data: fully conditional specification versus multivariate normal imputation. Am J Epidemiol. 2010 Mar 1;171(5):624-32.

116. White IR, Royston P, Wood AM. Multiple imputation using chained equations: Issues and guidance for practice. Stat Med. 2011 Feb 20;30(4):377-99.

117. Trach DD, Clemens JD, Ke NT, Thuy HT, Son ND, Canh DG, et al. Field trial of a locally produced, killed, oral cholera vaccine in Vietnam. Lancet Lond Engl. 1997 Jan 25;349(9047):231-5.

118. Sur D, Lopez AL, Kanungo S, Paisley A, Manna B, Ali M, et al. Efficacy and safety of a modified killed-whole-cell oral cholera vaccine in India: an interim analysis of a cluster-randomised, double-blind, placebo-controlled trial. The Lancet. 2009;374(9702):1694-702.

119. Clemens JD, Sack DA, Harris JR, Van Loon F, Chakraborty J, Ahmed F, et al. Field trial of oral cholera vaccines in Bangladesh: results from three-year followup. Lancet Lond Engl. 1990 Feb 3;335(8684):270-3.

120. Clemens JD, Harris JR, Sack DA, Chakraborty J, Ahmed F, Stanton BF, et al. Field trial of oral cholera vaccines in Bangladesh: results of one year of follow-up. J Infect Dis. 1988 Jul;158(1):60-9.

121. Clemens JD, Sack DA, Rao MR, Chakraborty J, Khan MR, Kay B, et al. Evidence that inactivated oral cholera vaccines both prevent and mitigate Vibrio cholerae 01 infections in a cholera-endemic area. J Infect Dis. 1992 Nov;166(5):1029-34.

122. Qadri F, Ali M, Chowdhury F, Khan AI, Saha A, Khan IA, et al. Feasibility and effectiveness of oral cholera vaccine in an urban endemic setting in Bangladesh: a cluster randomised open-label trial. Lancet Lond Engl. 2015 Oct 3;386(10001):1362-71.

123. Wierzba TF, Kar SK, Mogasale VV, Kerketta AS, You YA, Baral P, et al. Effectiveness of an oral cholera vaccine campaign to prevent clinically-significant cholera in Odisha State, India. Vaccine. 2015 May 15;33(21):2463-9.

124. Sanchez JL, Hayashi KE, Kruger HF, Meza R, English CK, Vidal W, et al. Immunological response to Vibrio cholerae 01 infection and an oral cholera vaccine among Peruvians. Trans R Soc Trop Med Hyg. 1995 Oct;89(5):542-5.

125. Guidance on how to access the Oral Cholera Vaccine (OCV) from the ICG emergency stockpile. :19.

126. Lusaka district, Zambia. Oral cholera vaccination second round 2016: technical report.

127. Zambia xenophobic riots: Two burned alive in Lusaka - BBC News [Internet]. [cited 2019 Aug 3]. Available from: https://www.bbc.com/news/worldafrica-36092917

128. Ferreras E, Matapo B, Chizema-Kawesha E, Chewe O, Mzyece H, Blake A, et al. Delayed second dose of oral cholera vaccine administered before high-risk period for cholera transmission: Cholera control strategy in Lusaka, 2016. PloS One. 2019;14(8):e0219040.

129. Parker LA, Rumunu J, Jamet C, Kenyi Y, Lino RL, Wamala JF, et al. Adapting to the global shortage of cholera vaccines: targeted single dose cholera vaccine in response to an outbreak in South Sudan. Lancet Infect Dis. 2017;17(4):e123-7. 
130. Haiti Opens a Drive to Vaccinate 820,000 as Cholera Flares - The New York Times [Internet]. [cited 2019 Sep 2]. Available from: https://www.nytimes.com/2016/11/10/world/americas/haiti-cholerahurricane-matthew.html

131. Cholera vaccine faces major test in war-torn Yemen | Science | AAAS [Internet]. [cited 2019 Sep 2]. Available from: https://www.sciencemag.org/news/2017/06/cholera-vaccine-faces-major-testwar-torn-yemen

132. Qadri F, Bhuiyan TR, Sack DA, Svennerholm A-M. Immune responses and protection in children in developing countries induced by oral vaccines. Vaccine. 2013 Jan 7;31(3):452-60.

133. Dimitrov DT, Troeger C, Halloran ME, Longini IM, Chao DL. Comparative effectiveness of different strategies of oral cholera vaccination in bangladesh: a modeling study. PLoS Negl Trop Dis. 2014 Dec;8(12):e3343.

134. Roy M. Anderson, Robert M. May. Infectious Diseases of Humans: Dynamics and Control [Internet]. Oxford Science Publications. 1991 [cited 2019 Sep 2]. Available from: https://www.amazon.es/Infectious-Diseases-Humans-DynamicsPublications/dp/019854040X

135. Halloran ME, Haber M, Longini IM, Struchiner CJ. Direct and Indirect Effects in Vaccine Efficacy and Effectiveness. Am J Epidemiol. 1991 Feb 15;133(4):323-31. 136. Halloran ME, Struchiner CJ, Longini IM. Study designs for evaluating different efficacy and effectiveness aspects of vaccines. Am J Epidemiol. 1997 Nov 15;146(10):789-803.

137. Luquero FJ, Grout L, Ciglenecki I, Sakoba K, Traore B, Heile M, et al. First outbreak response using an oral cholera vaccine in Africa: vaccine coverage, acceptability and surveillance of adverse events, Guinea, 2012. PLoS Negl Trop Dis. 2013;7(10):e2465.

138. Phares CR, Date K, Travers P, Déglise C, Wongjindanon N, Ortega L, et al. Mass vaccination with a two-dose oral cholera vaccine in a long-standing refugee camp, Thailand. Vaccine. 2016 Jan 2;34(1):128-33.

139. Khan IA, Saha A, Chowdhury F, Khan AI, Uddin MJ, Begum YA, et al. Coverage and cost of a large oral cholera vaccination program in a high-risk cholera endemic urban population in Dhaka, Bangladesh. Vaccine. 2013 Dec 9;31(51):6058-64.

140. Lam E, Al-Tamimi W, Russell SP, Butt MOI, Blanton C, Musani AS, et al. Oral Cholera Vaccine Coverage during an Outbreak and Humanitarian Crisis, Iraq, 2015. Emerg Infect Dis. 2017 Jan;23(1):38-45.

141. Uddin MJ, Wahed T, Saha NC, Kaukab SST, Khan IA, Khan AI, et al. Coverage and acceptability of cholera vaccine among high-risk population of urban Dhaka, Bangladesh. Vaccine. 2014 Sep 29;32(43):5690-5.

142. Tohme RA, François J, Wannemuehler K, Iyengar P, Dismer A, Adrien P, et al. Oral Cholera Vaccine Coverage, Barriers to Vaccination, and Adverse Events following Vaccination, Haiti, 20131. Emerg Infect Dis. 2015 Jun;21(6):984-91.

143. British Broadcasting Corporation. Zambia xenophobic riots: two burned alive in Lusaka. 2016; Available from: http://www.bbc.com/news/world-africa36092917

144. Ferreras E, Chizema-Kawesha E, Blake A, Chewe O, Mwaba J, Zulu G, et al. Single-Dose Cholera Vaccine in Response to an Outbreak in Zambia. N Engl J Med. 2018 08;378(6):577-9. 
BIBLIOGRAFÍA | 160 
ANEXOS 



\section{ANEXOS}

\subsection{Anexo 1. Publicaciones relacionadas}

1. Bi Q, Ferreras E, Pezzoli L, Legros D, Ivers LC, Date $K$, et al. Protection against cholera from killed whole-cell oral cholera vaccines: a systematic review and meta-analysis. Lancet Infect Dis. 2017 Oct;17(10):1080-8.

2. Ferreras E, Chizema-Kawesha E, Blake A, Chewe O, Mwaba J, Zulu G, et al. Single-Dose Cholera Vaccine in Response to an Outbreak in Zambia. N Engl J Med. 2018 08;378(6):577-9.

3. Ferreras E, Matapo B, Chizema-Kawesha E, Chewe O, Mzyece H, Blake A, et al. Delayed second dose of oral cholera vaccine administered before highrisk period for cholera transmission: Cholera control strategy in Lusaka, 2016. PloS One. 2019;14(8):e0219040.

4. Marc Poncin, Gideon Zulu, Caroline Voute, Eva Ferreras, Clara Mbwili Muleya, Kennedy Malama, et al. Implementation research: the feasibility of a reduced-dose mass cholera vaccination campaign in response to an outbreak in Lusaka, Zambia. Bull World Health Organ. 2018 Feb;96(2):8693.

5. Mwaba J, Ferreras E, Chizema-Kawesa E, Mwimbe D, Tafirenyika F, Rauzier J, et al. Evaluation of the SD bioline cholera rapid diagnostic test during the 2016 cholera outbreak in Lusaka, Zambia. Trop Med Int Health TM IH. 2018 May 31;

6. Ferreras $\mathbf{E}$ et al. Alternative observational designs to estimate the effectiveness of one dose of oral cholera vaccine in Lusaka, Zambia. E\&I. IN PRESS 
ANEXOS | 164 
Protection against cholera from killed whole-cell oral cholera vaccines: a systematic review and metaanalysis.

Lancet Infectious Diseases. 2017 Oct;17(10):1080-8. 



\section{Protection against cholera from killed whole-cell oral cholera vaccines: a systematic review and meta-analysis}

\section{Qifang Bi, Eva Ferreras, Lorenzo Pezzoli, Dominique Legros, Louise Clvers, Kashmira Date, Firdausi Qadri, Laura Digilio, David A Sack, Mohammad Ali, Justin Lessler, Francisco L Luquero, Andrew S Azman, on behalf of the Oral Cholera Vaccine Working Group of The Global Task Force on Cholera Control*}

\section{Summary}

Background Killed whole-cell oral cholera vaccines (kOCVs) are becoming a standard cholera control and prevention tool. However, vaccine efficacy and direct effectiveness estimates have varied, with differences in study design, location, follow-up duration, and vaccine composition posing challenges for public health decision making. We did a systematic review and meta-analysis to generate average estimates of kOCV efficacy and direct effectiveness from the available literature.

Methods For this systematic review and meta-analysis, we searched PubMed, Embase, Scopus, and the Cochrane Review Library on July 9, 2016, and ISI Web of Science on July 11, 2016, for randomised controlled trials and observational studies that reported estimates of direct protection against medically attended confirmed cholera conferred by kOCVs. We included studies published on any date in English, Spanish, French, or Chinese. We extracted from the published reports the primary efficacy and effectiveness estimates from each study and also estimates according to number of vaccine doses, duration, and age group. The main study outcome was average efficacy and direct effectiveness of two kOCV doses, which we estimated with random-effect models. This study is registered with PROSPERO, number CRD42016048232.

Findings Seven trials (with 695 patients with cholera) and six observational studies (217 patients with cholera) met the inclusion criteria, with an average two-dose efficacy of $58 \%(95 \%$ CI $42-69, \Gamma=58 \%)$ and effectiveness of $76 \%(62-85$, $\left.R^{2}=0\right)$. Average two-dose efficacy in children younger than 5 years $(30 \%$ [95\% CI $\left.15-42], I^{2}=0 \%\right)$ was lower than in those 5 years or older $(64 \%$ [ $\left.58-70], I^{2}=0 \% ; p<0 \cdot 0001\right)$. Two-dose efficacy estimates of kOCV were similar during the first 2 years after vaccination, with estimates of $56 \%\left(95 \%\right.$ CI $\left.42-66, I^{2}=45 \%\right)$ in the first year and $59 \%\left(49-67, I^{2}=0\right)$ in the second year. The efficacy reduced to $39 \%$ (13 to $57, R_{2}=48 \%$ ) in the third year, and $26 \%(-46$ to $63, R=74 \%)$ in the fourth year.

Interpretation Two kOCV doses provide protection against cholera for at least 3 years. One kOCV dose provides at least short-term protection, which has important implications for outbreak management. kOCVs are effective tools for cholera control.

Funding The Bill \& Melinda Gates Foundation.

Copyright This is an Open Access article published under the CC BY 3.0 IGO license which permits unrestricted use, distribution, and reproduction in any medium, provided the original work is properly cited. In any use of this article, there should be no suggestion that WHO endorses any specific organisation, products, or services. The use of the WHO logo is not permitted. This notice should be preserved along with the article's original URL.

\section{Introduction}

For years, cholera vaccines were used infrequently because of gaps in evidence on efficacy and field effectiveness across different populations, high costs, vaccine supply constraints, and concerns about diverting resources from other cholerarelated interventions. Killed whole-cell oral cholera vaccines (kOCVs) are now becoming part of the standard cholera control and prevention toolkit, in addition to the established water, sanitation, and hygiene interventions, surveillance, and case management. ${ }^{1}$ Although $\mathrm{kOCV}$ s have been used across multiple settings and have been shown to be safe and immunogenic, ${ }^{2-4}$ effectiveness and efficacy studies have provided a wide range of effect estimates, ${ }^{5-9}$ hindering clear communication to policy makers and clinicians.
The current formulation of kOCVs is like those first developed in the $1970 \mathrm{~s}$ and $1980 \mathrm{~s}^{10}$ and includes killed Vibrio cholerae whole cells from both main serotypes, Ogawa and Inaba, with the main antigen being the lipopolysaccharide of killed bacteria. The vaccines' lipopolysaccharide concentration has increased since the original vaccines were developed, and some kOCVs contain the cholera toxin B-subunit, which was shown to provide no added protection in follow-up assessments more than 6 months after vaccination." Available vaccines are licensed as two-dose regimens, although single-dose regimens have been tested and suggested as a possibility in outbreaks or when vaccine supply is low."
Lancet Infect Dis 2017 Published Online July 17, 2017 http: //dx.doi.org/10.1016 S1473-3099(17)30359-6 See Online/Comment http://dx.doi.org/10.1016/ 1473-3099(17)30420-6 Members listed in the appendix Department of Epidemiology, Johns Hopkins Bloomberg School of Public Health, Baltimore, MD, USA (Q Bi MHS, J Lessler PhD, A S Azman PhD); Environmental and Cancer Epidemiology Unit, National Centre for Epidemiology, Carlos III Institute of Health Madrid, Spain (E Ferreras MPH); Consortium for Biomedical Research in Epidemiology and Public Health (CIBERESP), Carlos III Institute of Health, Madrid, Spain (E Ferreras); World Health Organization, Geneva, Switzerland (L. Pezzoli PhD, D Legros MD); Department of Medicine, Division of Global Health Equity, Brigham and Women's Hospital, Boston, MA, USA (LC Ners MD); Department of Global Health and Social Medicine, Harvard Medical School, Boston, MA, USA (LC Vivers); United States Centers for Disease Control and Prevention, Atlanta, GA, USA (K Date MD): International Centre for Diarrhoeal Disease Research Bangladesh, Dhaka, Bangladesh ( $F$ Qadri PhD); International Vaccine Institute, Seoul, South Korea (L. Digilio MD); Department of International Health, Johns Hopkins Bloomberg School of Public Health, Baltimore, MD, USA (Prof D A Sack MD, M Ali PhD, FJ Luquero PhD): Epicentre, Paris, France (FJ Luquero); and Médecins Sans Frontières, Geneva, Switzerland (A S Azman) 


\section{Articles}

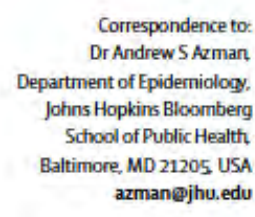

See Online for appendix
Research in context

Evidence before this study

Killed oral cholera vaccines (KOCVs) are increasingly becoming a standard cholera prevention and control tool, although a dear synthesis of the evidence supporting the degree of vaccine-derived protection is not available. We searched PubMed and Embase electronic databases for articles in English, Spanish, French, or Chinese published before April 31, 2017, using the key words "cholera" and "vaccine" and ("efficacy" or "effectiveness" or "protect" ") in the title or abstract. We also consulted members of the WHO Global Task Force for Cholera Control Oral Cholera VaccineWorking Group for any additional publications that might have been missed by the search. We identified avariety of publications from efficacy and effectiveness studies of oral cholera vaccines. In addition, a single systematic review of oral cholera vaccines, both live and killed, was identified, which covered only early efficacy and safety trials. The results showed moderate vaccine efficacy 2 years after vaccination with two doses of $\mathrm{kOCVs}$, and very scarce data from subsequentyears were available. Children younger than 5 years were observed to have lower efficacy than those aged 5 years and older.

\section{Added value of this study}

Our study builds upon the previous review of the efficacy of $\mathrm{kOCV}$ s by incorporating the additional evidence (ten new manuscripts comprising eight new studies) published since 2010 , including nearly all the evidence generated with the most widely used vaccine, Shanchol (Shantha Biotechnics,

In 2013, a global stockpile of kOCV was created by WHO to ensure vaccine availability for cholera control in outbreaks or humanitarian crises. ${ }^{12}$ Gavi, The Vaccine Alliance, later committed to fund up to 70 million doses (about US\$1.85 per dose) from 2014 to 2018 to expand the support for vaccination in emergency and non-emergency (hotspot) settings through the stockpile. ${ }^{n}$ These stockpiles, combined with the WHO prequalification of a lowcost vaccine (Shanchol; Shantha Biotechnics, Hyderabad, India) in 2011, paved the way for expanded access and increased use of the vaccine. Although travellers to cholera-prone areas commonly use kOCVs, ${ }^{13}$ most of the world's supply of $\mathrm{kOCV}$ is managed and deployed through these stockpiles. Countries wishing to use these vaccines must apply through either the emergency (International Coordinating Group) or non-emergency (Global Task Force on Cholera Control [GTFCC]) mechanisms. ${ }^{1}$ Supply of kOCV remains low relative to the size of the at-risk population. ${ }^{11}$ The WHO prequalification of a third kOCV (Euvichol; Eubiologics, Seoul, South Korea) in 2015, led to increased availability of these vaccines, opening the possibility for larger campaigns and the broader introduction of the vaccine in highburden areas. ${ }^{15}$

We present the results of a systematic review and meta-analysis of the published literature on the efficacy and effectiveness of kOCVs. Although the public health
Hyderabad, India). In contrast to the previous review, our study incorporates field effectiveness studies that are of greater relevance to field use and includes subanalyses to help elucidate the heterogeneity in efficacy or effectiveness estimates. We found that average two-dose efficacy is similar during the first 2 years after vaccination and begins to decline in the third year with positive, but not statistically significant, protection in the fourth year. However, by contrast, one large clinical trial estimated high levels of protection in the fifth year after vaccination. Short-term effectiveness (the firstyear after vaccination) is similar between one-dose and two-dose regimens. Even with the indusion of new evidence, children younger than 5 years are only about half as protected as those aged 5 years and older. Finally, we found that the median age of cases enrolled in studies had a strong positive relationship with the estimated level of protection conferred by the vaccine, which helps explain some of the differences between estimates.

Implications of all the available evidence

$\mathrm{kOCV}$ s can provide medium to high levels of protection for at least 3 years, if not longer, when provided as the standard two-dose regimen. One dose can provide similar short-term protection to two doses, making it a practical option in outbreaks in which a rapid reduction in short-term risk is needed. More research is needed to understand duration of protection of both one-dose and two-dose regimens and to understand if and when booster doses should be provided.

impact of kOCVs is derived from both the direct protection in vaccinated individuals and the indirect (herd) protection in both vaccinated and unvaccinated individuals, we focus this review on direct vaccine protection. We summarise the current state of evidence for kOCV protection to aid clinicians and public health decision makers to assess vaccine use at the individual and population levels.

\section{Methods}

\section{Search strategy and selection criteria}

This systematic review and meta-analysis adhered to the Preferred Reporting Items for Systematic Review and Meta-Analyses (PRISMA) guidelines.

We searched PubMed, Embase, Scopus, and the Cochrane Review Library databases on July 9, 2016, and ISI Web of Science on July 11, 2016, for articles containing "cholera" and "vaccine" and ("efficacy" or "effectiveness" or "protect") in the title or abstract (appendix p 2). We imposed no restrictions on publication date or language in the initial search. We consulted GTFCC Oral Cholera Vaccine Working Group members to identify additional publications.

We defined vaccine efficacy as the relative reduction in medically attended confirmed cholera risk in individuals that received the vaccine versus those who did not, as estimated by a randomised clinical trial (RCT). We 


\section{Articles}

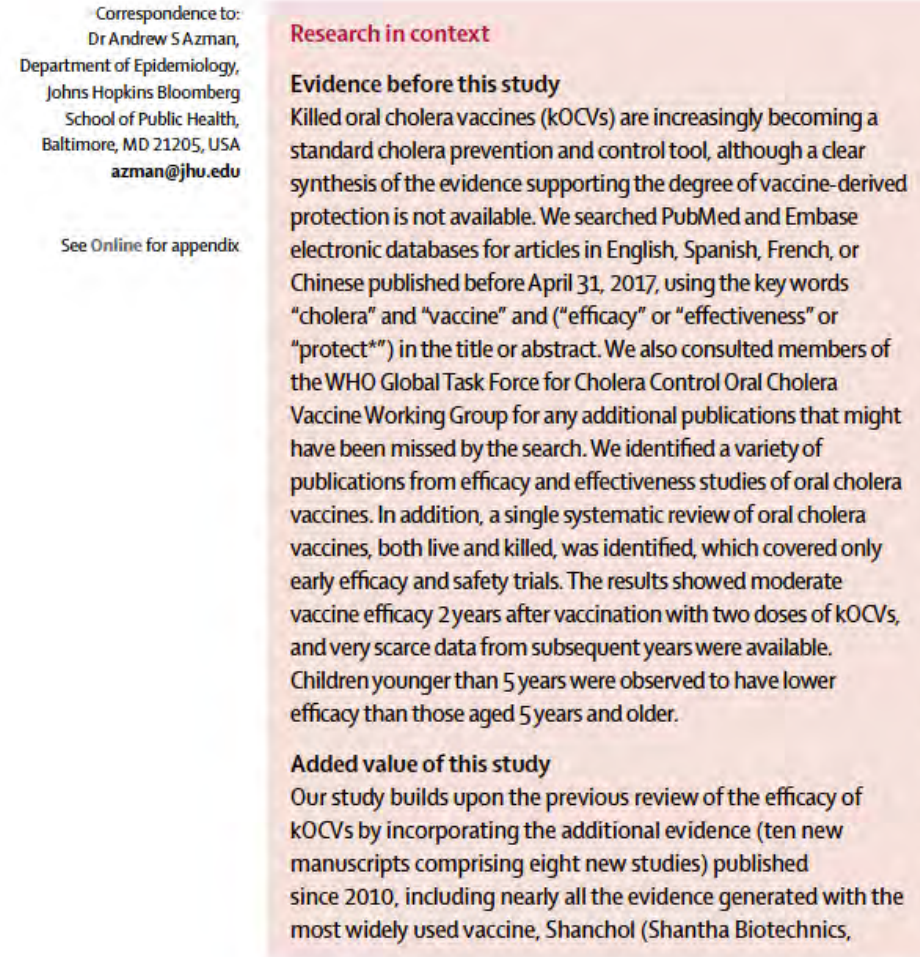

In 2013, a global stockpile of kOCV was created by WHO to ensure vaccine availability for cholera control in outbreaks or humanitarian crises. ${ }^{12}$ Gavi, The Vaccine Alliance, later committed to fund up to 70 million doses (about US\$1.85 per dose) from 2014 to 2018 to expand the support for vaccination in emergency and non-emergency (hotspot) settings through the stockpile." These stockpiles, combined with the WHO prequalification of a lowcost vaccine (Shanchol; Shantha Biotechnics, Hyderabad, India) in 2011, paved the way for expanded access and increased use of the vaccine. Although travellers to cholera-prone areas commonly use kOCVs, ${ }^{13}$ most of the world's supply of kOCV is managed and deployed through these stockpiles. Countries wishing to use these vaccines must apply through either the emergency (International Coordinating Group) or non-emergency (Global Task Force on Cholera Control [GTFCC]) mechanisms. ${ }^{1}$ Supply of kOCV remains low relative to the size of the at-risk population. ${ }^{1,1}$ The WHO prequalification of a third kOCV (Euvichol; Eubiologics, Seoul, South Korea) in 2015, led to increased availability of these vaccines, opening the possibility for larger campaigns and the broader introduction of the vaccine in highburden areas. ${ }^{15}$

We present the results of a systematic review and meta-analysis of the published literature on the efficacy and effectiveness of kOCVs. Although the public health
Hyderabad, India). In contrast to the previous review, our study incorporates field effectiveness studies that are of greater relevance to field use and includes subanalyses to help elucidate the heterogeneity in efficacy or effectiveness estimates. We found that average two-dose efficacy is similar during the first 2 years after vaccination and begins to decline in the third year with positive, but not statistically significant, protection in the fourth year. However, by contrast, one large clinical trial estimated high levels of protection in the fifth year after vaccination. Short-term effectiveness (the first year after vaccination) is similar between one-dose and two-dose regimens. Even with the inclusion of new evidence, children younger than 5 years are only about half as protected as those aged 5 years and older. Finally, we found that the median age of cases enrolled in studies had a strong positive relationship with the estimated level of protection conferred by the vaccine, which helps explain some of the differences between estimates.

Implications of all the available evidence kOCVs can provide medium to high levels of protection for at least 3 years, if not longer, when provided as the standard two-dose regimen. One dose can provide similar short-term protection to two doses, making it a practical option in outbreaks in which a rapid reduction in short-term risk is needed. More research is needed to understand duration of protection of both one-dose and two-dose regimens and to understand if and when booster doses should be provided.

impact of kOCVs is derived from both the direct protection in vaccinated individuals and the indirect (herd) protection in both vaccinated and unvaccinated individuals, we focus this review on direct vaccine protection. We summarise the current state of evidence for $\mathrm{kOCV}$ protection to aid clinicians and public health decision makers to assess vaccine use at the individual and population levels.

\section{Methods}

\section{Search strategy and selection criteria}

This systematic review and meta-analysis adhered to the Preferred Reporting Items for Systematic Review and Meta-Analyses (PRISMA) guidelines.

We searched PubMed, Embase, Scopus, and the Cochrane Review Library databases on July 9, 2016, and ISI Web of Science on July 11, 2016, for articles containing "cholera" and "vaccine" and "efficacy" or "effectiveness" or "protect") in the title or abstract (appendix p 2). We imposed no restrictions on publication date or language in the initial search. We consulted GTFCC Oral Cholera Vaccine Working Group members to identify additional publications.

We defined vaccine efficacy as the relative reduction in medically attended confirmed cholera risk in individuals that received the vaccine versus those who did not, as estimated by a randomised clinical trial (RCT). We 


\section{Articles}

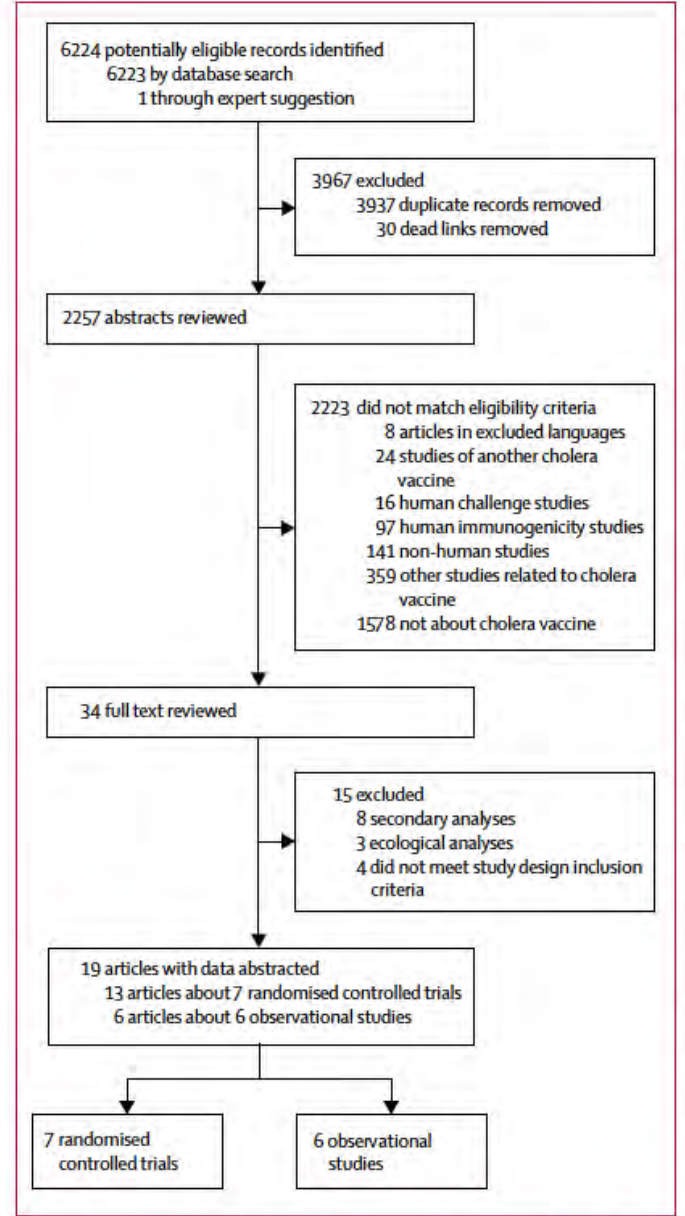

Figure 1: PRISMA flow chart highlighting details of the systematic review and data abstraction process

Of the four studies that did not meet the study design inclusion criteria, one was excluded because it included medically attended cases and those detected from active surveillance in a clinical trial, ${ }^{21}$ one was excluded because of a non-standard study design, ${ }^{21}$ the others ${ }^{3324}$ only used suspected, not confirmed cholera, as the study endpoint. The 359 other studies related to cholera vaccine that did not match eligibility criteria included commentaries, reviews, policy pieces, computational modelling, and studies with non-cholera outcomes related to any cholera vaccine.

Two studies had a low risk of bias across all domains of study quality, ${ }^{2,29}$ three had a low risk of bias across most domains but at least one area with an unclear risk of bias, ${ }^{5.2530}$ and two had at least one domain with a high risk of bias (appendix p 5). ${ }^{26,27}$

The six effectiveness studies eligible for analysis included four case-control studies, ${ }^{7.8353,36}$ one cohort study, ${ }^{34}$ and one case-cohort study. ${ }^{37}$ Most studies enrolled all individuals seeking care for diarrhoea at study health centres as suspected cholera cases then confirmed by stool culture, except two studies that used $\mathrm{PCR}^{37}$ and rapid diagnostic tests ${ }^{7}$ in their main analyses. Controls in case-control studies included people with no diarrhoea matched spatially to patients' residences, ${ }^{78,35}$ and clinicbased controls with non-cholera diarrhoea. ${ }^{36}$ Five studies included effectiveness of a two-dose regimen as their primary endpoint, ${ }^{7.834-36}$ and one study used a single-dose regimen. ${ }^{37}$ The duration between the two primary vaccine doses in observational studies ranged from 12 to 25 days. ${ }^{3.35}$ Three of the six studies ${ }^{7.835}$ had a low risk of selection bias and four ${ }^{78,35,37}$ had a low risk of bias related to the comparability of the groups both in the design and analysis. None of the case-control studies adequately reported on response rates for both cases and controls to judge the risk of bias. The cohort and the case-cohort studies had an unclear risk of bias because of inadequate reporting on the quality of the cohort follow-up and potential differences between participants who were lost to follow-up and those who remained in the cohort (appendix p 6).

Primary estimates of two-dose regimens were available in six $\mathrm{RCT}^{5,2-2,30.31}$ and five observational studies ${ }^{78,34-36}$ (tables 1, 2). Observational study estimates pertained to protection for 5-34 months after vaccination, with an 18-month weighted mean duration (figure 2). Trial estimates pertained to protection for 4-36 months, with a 28-month weighted mean duration (figure 2). The average two-dose efficacy was $58 \%$ (95\% CI $42-69$, $I^{2}=58 \%$ ) and the average two-dose effectiveness was $76 \%$ $(62-85, \quad[2=0)$. Two-dose estimates did not differ significantly by vaccine type $(\mathrm{p}=0.53$, whole-cell $v$ wC$\mathrm{BS}$ ); however, they varied by study design ( $\mathrm{p}=0.04$, observational $v s$ randomised designs). We did sensitivity analyses excluding trials using the WC-BS vaccines and found that the average two-dose efficacy $(57.4 \%$, weighted mean duration 28 months) and effectiveness (72.3\%, weighted mean duration 22 months) were similar, although slightly lower than the those from the combined analyses. We found no signs of publication bias from a visual assessment of funnel plots (appendix p 4) for observational studies and RCTs, separately.

One efficacy study ${ }^{28}$ and one effectiveness study ${ }^{37}$ used protection after one dose of KOCV as a primary outcome, both only providing estimates of short-term protection $\left(6\right.$ months $^{28}$ and 2 months $\left.\mathrm{s}^{37}\right)$. Other studies provided estimates of one-dose protection as secondary outcomes, including four observational studies ${ }^{7.3,3,36}$ and one RCT. ${ }^{28}$ Two studies containing onedose efficacy estimates (or data sufficient to estimate efficacy) did not meet inclusion criteria for the outcome of medically attended confirmed cholera. ${ }^{5,21}$ Given the paucity of evidence of longer-term single-dose protection, and the global discussions around single-dose use in outbreaks, we focused on estimating the short-term protection (up to 1 year after vaccination). The average short-term effectiveness of one-dose kOCV was $69 \%$ (95\% CI $\left.35-85, I^{2}=62 \%\right)$, although this conservatively included only two estimates of cumulative effectiveness 
Articles

\begin{tabular}{|c|c|c|c|c|c|c|c|c|}
\hline & Location & Study design & Vaccine & $\begin{array}{l}\text { Duration of } \\
\text { estimate(s)* }\end{array}$ & $\begin{array}{l}\text { Dose for } \\
\text { main } \\
\text { outcome }\end{array}$ & Study population & Serotypes & $\begin{array}{l}\text { Number of } \\
\text { patients with } \\
\text { cholerat }\end{array}$ \\
\hline Sur et al & Kolkata, India & $\begin{array}{l}\text { Cluster-randomised } \\
\text { placebo-controlled trial }\end{array}$ & Whole-cell & $\begin{array}{l}2 \text { years, }{ }^{29} 3 \text { years }(P), 31 \\
\text { and } 5 \text { years }\end{array}$ & Two & $\begin{array}{l}\text { All non-pregnant } \\
\text { individuals aged } \geq 1 \text { year }\end{array}$ & $\begin{array}{l}\text { Inaba and } \\
\text { Ogawa }\end{array}$ & 166 \\
\hline Taylor et al ${ }^{5}$ & Lima, Peru & $\begin{array}{l}\text { Individually randomised } \\
\text { placebo-controlled trial }\end{array}$ & $\begin{array}{l}\text { Whole-cell with } \\
\text { B-subunit }\end{array}$ & 2 years & Three & $\begin{array}{l}\text { All individuals } \\
\text { non-pregnant aged } \\
\text { 2-65years }\end{array}$ & $\begin{array}{l}\text { Inaba and } \\
\text { Ogawa }\end{array}$ & 7 \\
\hline Sanchez et a $\mathrm{P}^{\mathrm{p}}$ & Lima, Peru & $\begin{array}{l}\text { Individually randomised } \\
\text { placebo-controlled trial }\end{array}$ & $\begin{array}{l}\text { Whole-cell with } \\
\text { B-subunit }\end{array}$ & 5 months & Two & $\begin{array}{l}\text { Male military recruits } \\
\text { aged } 17-65 \text { years }\end{array}$ & Not reported & 16 \\
\hline 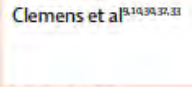 & Matlab, Bangladesh & $\begin{array}{l}\text { Individually randomised } \\
\text { placebo-controlled trial }\end{array}$ & $\begin{array}{l}\text { Whole-cell or } \\
\text { whole-cell with } \\
\text { B-subunit }\end{array}$ & $\begin{array}{l}6 \text { months }^{10} \text { and } 1 \text {, } \\
3(\mathrm{P}){ }^{30} \text { and } 4^{9} \text { years }\end{array}$ & Three & $\begin{array}{l}\text { Children aged } 2-15 \text { years } \\
\text { and all women aged } \\
>15 \text { years, non-pregnant }\end{array}$ & $\begin{array}{l}\text { Inaba and } \\
\text { Ogawa }\end{array}$ & 81 and $68 \neq$ \\
\hline Qadri et alpy & Dhaka, Bangladesh & Cluster randomised trial & Whole-cell & 2 years & Two & $\begin{array}{l}\text { All non-pregnant } \\
\text { individuals aged } \geq 1 \text { year }\end{array}$ & $\begin{array}{l}\text { Inaba and } \\
\text { Ogawa }\end{array}$ & 139 \\
\hline Qadriet ap ${ }^{8}$ & Dhaka, Bangladesh & $\begin{array}{l}\text { Individually randomised } \\
\text { placebo-controlled trial }\end{array}$ & Whole-cell & 6 months & One & $\begin{array}{l}\text { All non-pregnant } \\
\text { individuals aged } \geq 1 \text { year }\end{array}$ & $\begin{array}{l}\text { Inaba and } \\
\text { Ogawa }\end{array}$ & 101 \\
\hline Trach et aP ${ }^{6}$ & Hue, Vietnam & $\begin{array}{l}\text { Household randomised } \\
\text { trials without placebo }\end{array}$ & Whole-cell & 10 months & Two & $\begin{array}{l}\text { All individuals aged } \\
\geq 1 \text { year }\end{array}$ & Ogawa & 117 \\
\hline \multicolumn{9}{|c|}{$\begin{array}{l}\text {-When estimates pertaining to multiple durations (ie, times since vaccination) are presented, the primary endpoint duration that the trial design was based on is marked with (P). Some of the publications repor } \\
\text { multiple estimates with different cumulative durations, butwe have included the primary estimate durations from each publication here. tTotal number of patients with cholera from both vaccination and } \\
\text { placebo groups. \#Vaccine efficacy of at least one dose estimated in this study; } 81 \text { for whole-cell vaccine group and } 68 \text { for whole-cell vaccine with B-subunit group. SThe protective estimate in the study by Qadri } \\
\text { and colleagues" was characterised as efficacy because of the cluster randomised trial design. The study had no placebo group and the non-intervention groupwas used as the comparison group. We consider } \\
\text { random allocation of the exposure (vaccine) to be sufficient to classify an estimate as efficacy. The } 139 \text { patients refers to the patients in the vaccination-only intervention group that were used to assess total } \\
\text { protection. }\end{array}$} \\
\hline
\end{tabular}

\begin{tabular}{|c|c|c|c|c|c|c|c|c|}
\hline & Location & Study design & Vaccine & $\begin{array}{l}\text { Duration } \\
\text { of estimate }\end{array}$ & $\begin{array}{l}\text { Dose for } \\
\text { main } \\
\text { outcome }\end{array}$ & Study population & Serotypes & $\begin{array}{l}\text { Number of } \\
\text { patients with } \\
\text { cholera }\end{array}$ \\
\hline Wierzba et al ${ }^{\beta 5}$ & Puri District, India & Case control & Whole-cell & 34 months & Two & $\begin{array}{l}\text { All non-pregnant } \\
\text { individuals aged } \geq 1 \text { year }\end{array}$ & Ogawa & 35 \\
\hline Ivers et al ${ }^{8}$ & $\begin{array}{l}\text { Artibonite Department, } \\
\text { Haiti }\end{array}$ & Case control & Whole-cell & 22 months & Two & $\begin{array}{l}\text { All individuals aged } \\
\geq 1 \text { year }\end{array}$ & $\begin{array}{l}\text { Inaba } \\
\text { and Ogawa }\end{array}$ & 44 \\
\hline Luquero et al & $\begin{array}{l}\text { Boffa and Forecariah } \\
\text { Districts, Guinea }\end{array}$ & Case control & Whole-cell & 4 months & Two & $\begin{array}{l}\text { All individuals aged } \\
>1 \text { year }\end{array}$ & Ogawa & $26 t$ \\
\hline Khatib et $a^{34}$ & Zanzibar, Tanzania & Cohort & $\begin{array}{l}\text { Whole-cell with } \\
\text { B-subunit }\end{array}$ & 15 months & Two & $\begin{array}{l}\text { All non-pregnant } \\
\text { individuals aged } \geq 2 \text { years }\end{array}$ & Ogawa & 39 \\
\hline Lucas et als & Beira, Mozambique & Case control & $\begin{array}{l}\text { Whole-cell with } \\
\text { B-subunit }\end{array}$ & 4 months & Two & $\begin{array}{l}\text { All non-pregnant } \\
\text { individuals aged } \geq 2 \text { years }\end{array}$ & Ogawa & 39 \\
\hline Azman et al ${ }^{30}$ & Juba, South Sudan & Case cohort & Whole-cell & 2 months & One & $\begin{array}{l}\text { All individuals aged } \\
21 \text { year }\end{array}$ & Inaba & 34 \\
\hline
\end{tabular}

spanning over 1 year (figure 3D). ${ }^{8.34}$ The only published one-dose clinical trial estimated 6-month efficacy of $40 \%$ (95\% CI 11-60; figure 3B). Estimates did not vary significantly by study design $(\mathrm{p}=0.47$, randomised trial $\nu$ s observational). The average short-term one-dose effectiveness (69\% [95\% CI 35-85]; figure 3D) is similar to that of two doses (83\% [79-91]; $\mathrm{p}=0.31$; figure $3 \mathrm{C}$ ), although all evidence comes from populations in which cholera transmission regularly occurs (ie, immunologically primed populations).

We identified two efficacy studies that used three kOCV doses..$^{59}$ One study provided three doses, each 6 weeks apart (including whole-cell and WC-BS groups). ${ }^{9}$ After 3 years, the results of that study showed that the efficacy was not significantly different between two and three doses ( $64 \%$ vs $50 \%$ ) for the WC-BS group of the study, but twodose efficacy was significantly lower than three-dose efficacy for the whole-cell group (39\% vs $52 \%){ }^{30}$ The second study provided a third dose as a booster 10 months after the primary two-dose series and found that efficacy 2 years after the first dose was $82 \%$ ( $95 \%$ CI $27-95) .^{5}$

The average efficacy estimates of kOCV were similar during the first 2 years after vaccination (figure 3; appendix p 4), with estimates of $56 \%\left(95 \% \mathrm{CI} 42-66, I_{2}=45 \%\right)$ in the 
Articles

\begin{tabular}{|c|c|c|c|c|c|c|c|c|}
\hline & Location & Study design & Vaccine & $\begin{array}{l}\text { Duration of } \\
\text { estimate(s) }\end{array}$ & $\begin{array}{l}\text { Dose for } \\
\text { main } \\
\text { outcome }\end{array}$ & Study population & Serotypes & $\begin{array}{l}\text { Number of } \\
\text { patients with } \\
\text { cholerat }\end{array}$ \\
\hline Sur et al & Kolkata, India & $\begin{array}{l}\text { Cluster-randomised } \\
\text { olacebo-controlled trial }\end{array}$ & Whole-cell & $\begin{array}{l}2 \text { years, }^{.9} 3 \text { years }(P), 3^{31} \\
\text { and } 5 \text { years }^{6}\end{array}$ & Two & $\begin{array}{l}\text { All non-pregnant } \\
\text { individuals aged } \geq 1 \text { year }\end{array}$ & $\begin{array}{l}\text { Inaba and } \\
\text { Ogawa }\end{array}$ & 166 \\
\hline Taylor et al ${ }^{5}$ & Lima, Peru & $\begin{array}{l}\text { ndividually randomised } \\
\text { placebo-controlled trial }\end{array}$ & $\begin{array}{l}\text { Whole-cell with } \\
\text { B-subunit }\end{array}$ & 2 years & Three & $\begin{array}{l}\text { All individuals } \\
\text { non-pregnant aged } \\
2-65 \text { years }\end{array}$ & $\begin{array}{l}\text { Inaba and } \\
\text { Ogawa }\end{array}$ & 7 \\
\hline Sanchez et a $\mathrm{F}^{5}$ & Lima, Peru & $\begin{array}{l}\text { ndividually randomised } \\
\text { placebo-controlled trial }\end{array}$ & $\begin{array}{l}\text { Whole-cell with } \\
\text { B-subunit }\end{array}$ & 5 months & Two & $\begin{array}{l}\text { Male military recruits } \\
\text { aged } 17-65 \text { years }\end{array}$ & Not reported & 16 \\
\hline Clemens et al $\left.\right|^{3.19949 ., 31}$ & Matlab, Bangladesh Indi & $\begin{array}{l}\text { ndividually randomised } \\
\text { placebo-controlled trial }\end{array}$ & $\begin{array}{l}\text { Whole-cell or } \\
\text { whole-cell with } \\
\text { B-subunit }\end{array}$ & $\begin{array}{l}6 \text { months }{ }^{10} \text { and } 11^{, 3.35} \\
3(\mathrm{P}),{ }^{30} \text { and } 4^{9} \text { years }\end{array}$ & Three & $\begin{array}{l}\text { Children aged } 2-15 \text { years } \\
\text { and all women aged } \\
>15 \text { years, non-pregnant }\end{array}$ & $\begin{array}{l}\text { Inaba and } \\
\text { Ogawa }\end{array}$ & 81 and $68 \ddagger$ \\
\hline Qadri et al's & Dhaka, Bangladesh Clus & Cluster randomised trial & Whole-cell & 2 years & Two & $\begin{array}{l}\text { All non-pregnant } \\
\text { individuals aged } \geq 1 \text { year }\end{array}$ & $\begin{array}{l}\text { Inaba and } \\
\text { Ogawa }\end{array}$ & 139 \\
\hline Qadri et ap ${ }^{8}$ & $\begin{array}{r}\text { Dhaka, Bangladesh Indi } \\
\text { plac }\end{array}$ & $\begin{array}{l}\text { ndividually randomised } \\
\text { olacebo-controlled trial }\end{array}$ & Whole-cell & 6 months & One & $\begin{array}{l}\text { All non-pregnant } \\
\text { individuals aged } \geq 1 \text { year }\end{array}$ & $\begin{array}{l}\text { Inaba and } \\
\text { Ogawa }\end{array}$ & 101 \\
\hline Trach et a $\mathrm{P}^{6}$ & Hue, Vietnam & $\begin{array}{l}\text { Household randomised } \\
\text { trials without placebo }\end{array}$ & Whole-cell & 10 months & Two & $\begin{array}{l}\text { All individuals aged } \\
21 \text { year }\end{array}$ & Ogawa & 117 \\
\hline \multicolumn{9}{|c|}{$\begin{array}{l}\text {-When estimates pertaining to multiple durations (ie, times since vaccination) are presented, the prim } \\
\text { multiple estimates with different cumulative durations, butwe have included the primary estimate du } \\
\text { placebo groups. \#Vaccine efficacy of at least one dose estimated in this study, } 81 \text { for whole-cell vaccine } \\
\text { and colleagues" was characterised as efficacy because of the cluster randomised trial design. The study } \\
\text { random allocation of the exposure (vaccine) to be sufficient to classify an estimate as efficacy. The } 139 \\
\text { protection. }\end{array}$} \\
\hline & Location & Study design & Vaccine & $\begin{array}{l}\text { Duration } \\
\text { of estimate }\end{array}$ & $\begin{array}{l}\text { Dose for } \\
\text { main } \\
\text { outcome }\end{array}$ & Study population & Serotypes & $\begin{array}{l}\text { Number of } \\
\text { patients with } \\
\text { cholera }\end{array}$ \\
\hline Wierzba et a $\beta^{5}$ & Puri District, India & Case control & Whole-cell & 34 months & Two & $\begin{array}{l}\text { All non-pregnant } \\
\text { individuals aged } \geq 1 \text { year }\end{array}$ & Ogawa & 35 \\
\hline Ivers et al $\left.\right|^{8}$ & $\begin{array}{l}\text { Artibonite Department, } \\
\text { Haiti }\end{array}$ & t. Case control & Whole-cell & 22 months & Two & $\begin{array}{l}\text { All individuals aged } \\
\geq 1 \text { year }\end{array}$ & $\begin{array}{l}\text { Inaba } \\
\text { and Ogawa }\end{array}$ & 44 \\
\hline Luquero et al & $\begin{array}{l}\text { Boffa and Forecariah } \\
\text { Districts, Guinea }\end{array}$ & Case control & Whole-cell & 4 months & Two & $\begin{array}{l}\text { All individuals aged } \\
>1 \text { year }\end{array}$ & Ogawa & $26+$ \\
\hline Khatib et a ${ }^{34}$ & Zanzibar, Tanzania & Cohort & $\begin{array}{l}\text { Whole-cell with } \\
\text { B-subunit }\end{array}$ & 15 months & Two & $\begin{array}{l}\text { All non-pregnant } \\
\text { individuals aged } 22 \text { years }\end{array}$ & Ogawa & 39 \\
\hline Lucas et al $\left.\right|^{s 5}$ & Beira, Mozambique & Case control & $\begin{array}{l}\text { Whole-cell with } \\
\text { B-subunit }\end{array}$ & 4 months & Two & $\begin{array}{l}\text { All non-pregnant } \\
\text { individuals aged } \geq 2 \text { years }\end{array}$ & Ogawa & 39 \\
\hline Azman et aly & Juba, South Sudan & Case cohort & Whole-cell & 2 months & One & $\begin{array}{l}\text { All individuals aged } \\
21 \text { year }\end{array}$ & Inaba & 34 \\
\hline
\end{tabular}

spanning over 1 year (figure 3D). ${ }^{8.34}$ The only published one-dose clinical trial estimated 6-month efficacy of $40 \%$ (95\% CI 11-60; figure 3B). Estimates did not vary significantly by study design $(\mathrm{p}=0.47$, randomised trial $v$ s observational). The average short-term one-dose effectiveness (69\% [95\% CI 35-85]; figure 3D) is similar to that of two doses (83\% [79-91]; $\mathrm{p}=0.31$; figure $3 \mathrm{C}$ ), although all evidence comes from populations in which cholera transmission regularly occurs (ie, immunologically primed populations).

We identified two efficacy studies that used three kOCV doses. ${ }^{59}$ One study provided three doses, each 6 weeks apart (including whole-cell and WC-BS groups). ${ }^{9}$ After 3 years, the results of that study showed that the efficacy was not significantly different between two and three doses ( $64 \%$ vs $50 \%$ ) for the WC-BS group of the study, but twodose efficacy was significantly lower than three-dose efficacy for the whole-cell group (39\% vs $52 \%){ }^{30}$ The second study provided a third dose as a booster 10 months after the primary two-dose series and found that efficacy 2 years after the first dose was $82 \%(95 \%$ CI $27-95))^{5}$

The average efficacy estimates of $\mathrm{kOCV}$ were similar during the first 2 years after vaccination (figure 3 ; appendix p 4), with estimates of $56 \%\left(95 \%\right.$ CI $\left.42-66, R^{2}=45 \%\right)$ in the 


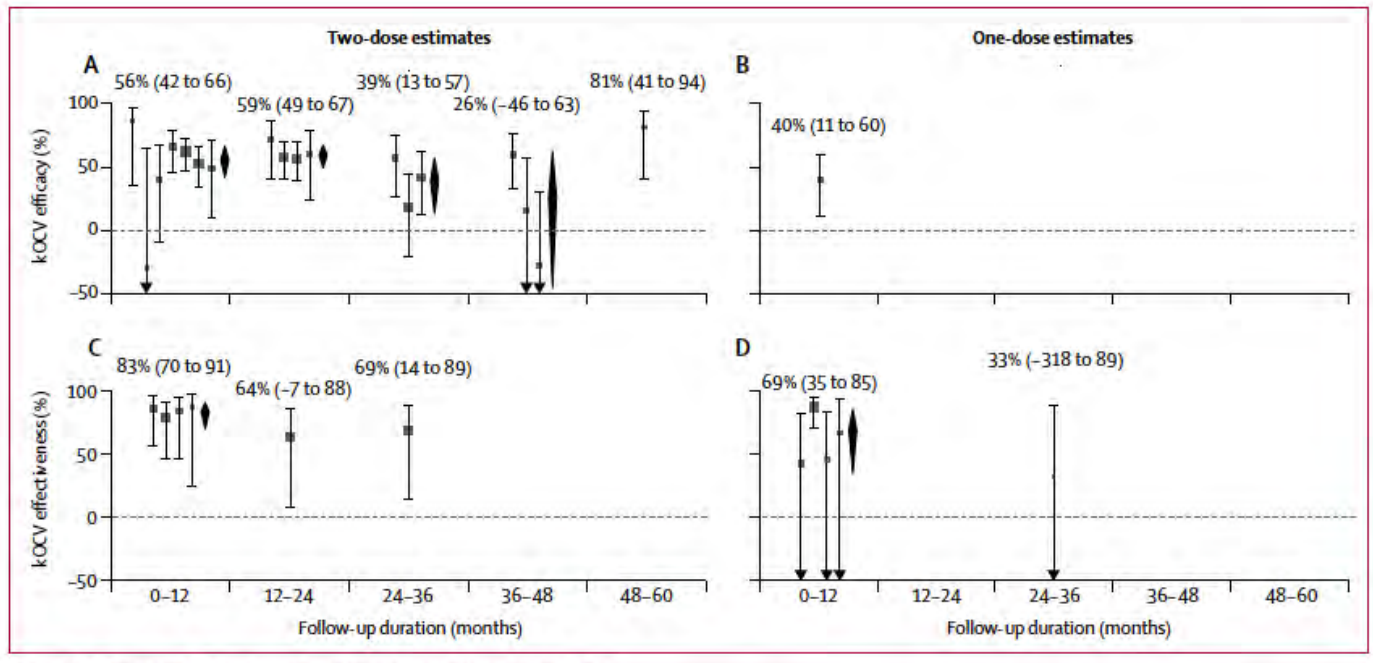

Figure 3: Efficacy and effectiveness by time since vaccination and dose

Follow-up durations are shown here as the midpoint of the time window during which the estimate was measured. (A) Two-dose efficacy estimates at $0-12$ months (from left to right, data from references 25, 5, 6, 26, 9 [WC-BS group], 9 [whole-cell group], and 27), 12-24 months (references 6, 9 [WC-BS], 9 [whole-cell], and 27), 24-36 months (references 6, 9 [WC-BS], and 9 [whole-cell]), 36-48 months (references 6, 9 [WC-BS], 9 [whole-cell]), and 48-60 months (reference 6). The study by van Loon and colleagues ${ }^{9}$ has two estimates at each relevant timepoint, because results were obtained for a whole-cell vaccine group and a whole-cell with B-subunit group. (B) One-dose efficacy estimate at 0-12 months. ${ }^{73}$ (C) Two-dose effectiveness estimates at 0-12 months (from left to right, data from references 7, 34, 35, and 8), 12-24 months, and 24-36 months. ${ }^{36}$ (D) One-dose effectiveness estimates at 0-12 months (from left to right, data from references 7, 37, 34, and 8) and 24-36 months ${ }^{36}$ Estimates are grouped by timeframe of analysis with zero representing the day of last dose of vaccine (dose dependent). Grey bars and squares show $95 \% \mathrm{Cls}$ and point estimates of efficacy or effectiveness from the literature. Black diamonds show the average efficacy or effectiveness and $95 \% \mathrm{Cl}$. Studies were grouped by time period and not all studies cover the entire 12-month period. $\mathrm{KOCV}=\mathrm{killed}$ whole-cell oral cholera vaccine. WC-BS=whole-cell with B subunit.

difference, a single-dose WC-BS vaccine could provide a more protective alternative than a whole-cell only vaccine. Whether and when to provide a booster dose remains an open question and might vary by the degree to which the population has previously been exposed to $V$ cholerae. New evidence on the duration of protection by one-dose and two-dose regimens will enhance the ability to make better decisions on when each should be used and at what intervals booster doses should be provided.

kOCVs, like other oral vaccines ${ }^{40}$ provide less protection to children younger than 5 years than to people aged 5 years or older. This differential protection by age might have implications for deciding between different vaccination strategies, particularly when kOCVs become more broadly used in highly endemic countries, such as Bangladesh. Vaccination of young children, despite the lower efficacy, might still have substantial effects on disease burden, because of indirect (herd) effects. ${ }^{41}$ More work is needed to refine estimates of the differential protection by age, to improve understanding of the effect of different age-targeted vaccine delivery strategies, and to understand whether alternative dosing regimens, such as the provision of a third dose, might enhance protection in young children.

The local epidemiology of cholera, including the pathways of transmission and the transmission intensity, can determine which age groups are at highest risk of becoming infected. ${ }^{42}$ In highly cholera-endemic settings such as Bangladesh and India, people with cholera tend

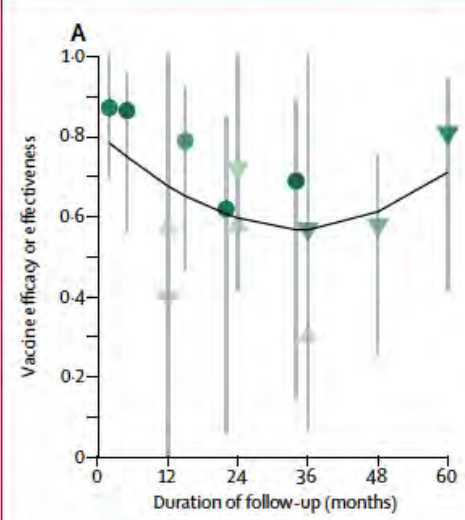

Median age of patients with cholera (years)

$\begin{array}{lllllllllllll}41.0 & 37.5 & 340 & 30.5 & 27.0 & 23.5 & 20.0 & 16.5 & 130 & 9 & 1 & 6 & 6.0\end{array}$

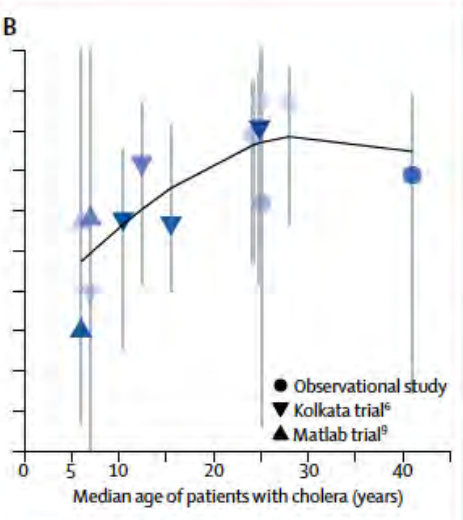

Duration of follow-up (months)

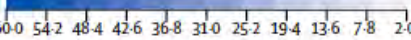

Figure 4: Relationship between protection by vaccine, duration of follow-up, and median age of patients with cholera

(A) Relationship between protection and months of follow-up. Shading shows median age of patients with cholera. (B) Relationship between protection and the median age of patients with cholera measured in years. Shading shows duration of follow-up. Lines in blackwere fit with a polynomial spline with three degrees of freedom. These plots only include a subset of data in which the age distributions of patients were available (all observational studies and two trials). ${ }^{5336-36}$ Error bars show $95 \% \mathrm{Cl}$

to be younger, since older adults benefit from protection conferred by previous exposure to $V$ cholerae. Given that efficacy of kOCVs is age dependent, the distribution of 


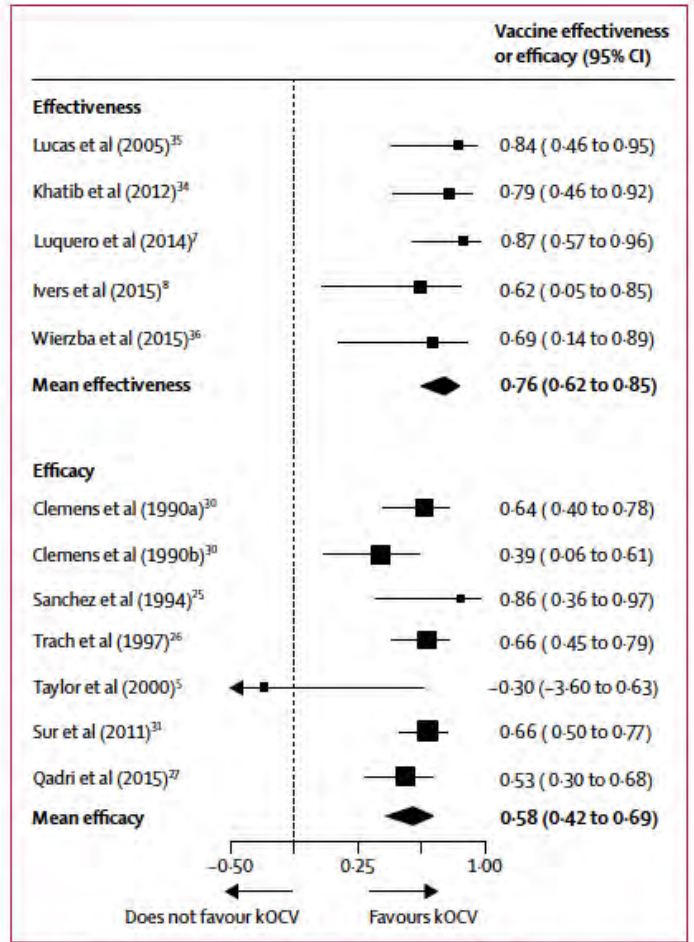

Figure 2: Effectiveness and efficacy main pooled analyses for two-dose killed whole-cell oral cholera vaccine

95\% Cls in the figure and used for meta-analyses are not necessarily the same as those in the original study because they were based on a reconstruction of a two-sided $95 \% \mathrm{Cl}$ from estimates of the standard error of the estimate from each study. All estimates (except for those from Clemens and colleagues, ${ }^{\text {pn }}$ $1990 \mathrm{a}$ and $1990 \mathrm{~b}$ ) use the main vaccine dose used in the study. Qadri and colleagues $^{\text {"I }}$ estimate is an estimate of total protection including both direct and indirect effects. Observational study effectiveness estimates had an 18-month weighted mean duration, and the trial efficacy estimates had a 28-month weighted mean duration.

first year and $59 \%(49-67,12=0)$ in the second year. The efficacy reduced to $39 \%\left(95 \%\right.$ CI 13 to $57, I^{2}=48 \%$ ) in the third year, and $26 \%(-46$ to $63, \Gamma=74 \%)$ in the fourth year, at which point the estimates of efficacy became highly variable between studies and the average efficacy confidence interval crossed zero. Only one study reported efficacy during the fifth year, which was $81 \%(95 \%$ CI $41-94){ }^{6}$

Age-group-specific estimates of protection were reported by five studies, ${ }^{25-27,30.31}$ with most dividing age groups into ages younger than 5 years, $5-15$ years, and older than 15 years. We estimated the average efficacy of $\mathrm{kOCV}$ in children younger than 5 years to be $30 \%$ ( $95 \%$ CI $15-42 ; \quad I 2=0 \%$, weighted mean duration of estimate 31 months), which is significantly less $(\mathrm{p}<0.0001)$ than in people aged 5 years or older $\left(64 \%\right.$; $95 \%$ CI $58-70 ; I^{2}=0 \%$, weighted mean duration 34 months), including estimates of efficacy in people aged 15 years and older (appendix p 3). The average effectiveness in children younger than 5 years is $78 \%$ ( $95 \% \mathrm{CI}-37$ to $96, I^{2}=0 \%$, weighted mean duration 9 months), which is similar ( $\mathrm{p}=0 \cdot 77$ ) to the effectiveness in individuals aged 5 years or older $(70 \%$, 44 to $84 ; I 2=0 \%$, weighted mean duration 14 months). However, the estimate for children younger than 5 years comes from only two studies containing a total of 18 patients younger than 5 years. ${ }^{8.35}$ In school-aged children (aged 5-15 years), the average efficacy is $80 \%$ (95\% CI 41-93), based on results of only two trials. ${ }^{2729}$

Given the differences in protection by age, we investigated whether the age distribution of cases within each study could explain the heterogeneity in efficacy or effectiveness estimates. Most studies did not report these data; however, authors of seven of the ten studies provided the requested data. ${ }^{67,9,273,34,36.37}$ We found that, in general, the older the patients, the higher the estimated protection (figure 4). The clearest example of this comes from the 5-year trial in Kolkata, ${ }^{6}$ in which a simple linear model predicts a rise of 2.0 percentage points $\left(95 \%\right.$ CI $0 \cdot 55-3 \cdot 4$, adjusted $\left.r^{2}=0.82\right)$ in efficacy for each $10 \%$ increase in the median age. Additional analyses are needed to explore this relationship between increasing age and efficacy, given that the data within studies (eg, the estimates from year to year) are correlated and that we used only a sample of data which we were able to obtain from study authors.

\section{Discussion}

Our analyses provide a summary of the available evidence on the protection conferred by kOCVs and help clarify the observed difference in estimates. We found that kOCVs administered as the standard two-dose regimen provide a moderate to high level of protection for at least 3 years, with some evidence suggesting longer lasting protection. A one-dose regimen provides significant short-term protection, although no studies with a primary endpoint of one-dose protection after longer than 6 months have been published. Two-dose efficacy is significantly less in children younger than 5 years than in people 5 years or older.

The choice of using a one-dose or two-dose regimen is difficult, particularly during outbreaks in regions where supplies are scarce. ${ }^{11,3,39}$ Our estimates of the short-term (up to 1 year after vaccination) average one-dose and two-dose effectiveness are similar, however, this comparison was not possible for efficacy studies because of scarce data. When short-term protection is needed and two doses cannot be provided to everyone at risk, our results suggest that a single dose will provide some if not the same level of short-term protection. Most evidence for the one-dose regimen comes from observational studies. More evidence from randomised trials is needed to corroborate increasing evidence that supports the strong protection conferred by a one-dose regimen. One study compared the short-term efficacy of three doses of whole-cell and WC-BS vaccines, and concluded that the inclusion of the B-subunit might have increased short-term protection. ${ }^{10}$ If this finding reflects a true 


\section{Articles}

the age of affected people probably shapes estimates of protection from studies done in different settings (appendix pp 3-4). Frequent exposure in endemic areas can act to boost vaccine-induced immunity and prolong duration of vaccine protection, and might influence the apparent protection from the vaccine. These phenomena, in addition to the differences in the durations of the studies, might explain why the two-dose effectiveness is higher than that of two-dose efficacy (figure 2). India is the only country in which both two-dose efficacy ${ }^{31}$ and effectiveness $^{36}$ studies were done, and protection estimates after about 3 years were very similar $\left(69 \%^{36}\right.$ and $66 \%^{3}$ ), showing that local epidemiology might explain apparent differences between study designs.

We identified moderate to high levels of heterogeneity between individual study estimates of vaccine protection within the primary two-dose efficacy analysis and within the average one-dose effectiveness analysis. Although some of the heterogeneity is explained by the duration of the study and the average age of patients, other unidentified factors probably also had a role. One outlier in the primary two-dose efficacy analysis, a trial done in Peru, ${ }^{25}$ found no protection during the 10 months after vaccination. The study ${ }^{25}$ assessed an early vaccine variant produced before large-scale dedicated production existed. Clemens and colleague ${ }^{43}$ suggested that misclassification of outcomes within this massive household-based active surveillance programme (with twice weekly visits to households of 18000 individuals) might have biased the results towards no effect.

This systematic review builds upon the 2011 Cochrane review $^{4}$ of oral cholera vaccination efficacy by incorporating four new manuscripts $s^{6,72.28,31}$ and two new clinical trials done since 2010 and including six fieldeffectiveness studies from a wider geographical scope, which provide measures of vaccine protection that are relevant to public health. Our estimates of two-dose efficacy and findings of low efficacy in children younger than 5 years are similar to those reported in the 2011 Cochrane review, ${ }^{4}$ which strengthens the rationale to look for alternative protection for young children through either herd immunity or the development of new vaccines. Additionally, we did subanalyses for protection by number of doses, age group, study type, and duration of protection to help explain some of the heterogeneity in estimates seen in the literature. This summary of the evidence is particularly timely because of the increases in global supply of kOCVs, and the increasing interest in incorporating its use into national cholera control plans in areas that have cholera outbreaks regularly.

This systematic review had multiple limitations. Given the few available studies and their diversity in study design, duration of follow-up, vaccine type, and epidemiological settings, we were unable to fully control for each factor in estimating the true average effect. We presented stratified estimates to help interpret how each factor might influence estimates of $\mathrm{kOCV}$ protection. In our analyses of single-dose protection, we combined estimates of one-dose protection from studies in which it was the primary outcome and studies in which it was a secondary outcome. Especially in observational settings, these secondary estimates are from individuals who did not get the full vaccine regimen, which might be correlated with cholera risk. If these data were from people who did not get the full regimen, we might have underestimated the average single-dose protection. Similarly, using both vaccine groups from the Matlab study ${ }^{30}$ without accounting for correlation between them (shared placebo group) led to slight underestimation of the variance in the average efficacy estimates. Last, although no significant differences between protection estimates using different vaccines were detected, the increase in antigen protection over time and the addition of the B-subunit might account for some undetected differences that this study was underpowered to detect. However, average two-dose estimates excluding the WC-BS vaccines were similar to the estimates pertaining to a combination of both vaccines.

In conclusion, kOCVs are effective in reducing the risk of cholera. Although vaccination alone will probably not lead to elimination of cholera, it can provide an important stopgap while improved water, sanitation, and healthcare infrastructure are provided to vulnerable populations. More work is needed to understand how and when to best use existing vaccines and to design new and more effective ones. However, the past three decades of evidence points towards $\mathrm{kOCV}$ being a safe, effective, and important tool to fight cholera.

Contributors

ASA, FJL, and DL conceptualised the paper. QB, EF, and ASA did data curation and abstraction. $\mathrm{QB}$ and $\mathrm{ASA}$ did formal analysis. $\mathrm{QB}, \mathrm{EF}$, ASA, FJL, and LP did the investigation. QB, EF, FJL, LP, and ASA prepared the original draft. All authors reviewed and provided critical feedback on the manuscript.

Declaration of interests

LP, DL, LCI, DAS, JL, and ASA report grants from the Bill \& Melinda Gates Foundation. QB, EF, KD, FQ, LD, MA, and FJL declare no competing interests.

Acknowledgments

We would like to thank the study investigators who provided supplemental data for these analyses and participants from all kOCV studies who together have made possible this new understanding of kOCVs. We also thank Maurice M M'bang'ombe (Malawi Ministry of Health), Jose Paulo (Mozambique Ministry of Health), Jeannot François (Haiti Ministry of Health), and Basu Dev Pandey (Nepal Ministry of Health) for their valuable contributions to the GTFCC related to OCV use. This study was funded by WHO by a grant from The Bill \& Melinda Gates Foundation. ASA, JL and DAS were funded by The Bill \& Melinda Gates Foundation (OPP10892431 for ASA and JL and OPP1053556 for ASA and DAS).

References

1 WHO. Weekly epidemiological record, 2 June 2017, vol. 22, 92 (pp 301-20). http://apps.who.int/iris/bitstream/10665/255611/1/ WER9222.pdf?ua=1 (accessed June 17, 2017).

2 Saha A, Chowdhury MI, Khanam F, et al. Safety and immunogenicity study of a killed bivalent (O1 and $\mathrm{O} 139)$ whole-cell oral cholera vaccine Shanchol, in Bangladeshi adults and children as young as 1 year of age. Vaccine 2011; 29: 8285-92.

3 Desai SN, Akalu Z, Teferi M, et al. Comparison of immune responses to a killed bivalent whole cell oral cholera vaccine between endemic and less endemic settings. Trop Med Int Health 2016; 21: 194-201. 
4 Jertborn M, Svennerholm AM, Holmgren J. Safety and immunogenicity of an oral recombinant cholera B subunitwhole cell vaccine in Swedish volunteers. Vacaine 1992; 10: 130-32.

5 Taylor DN, Cárdenas V, Sanchez JL, et al. Two-year study of the protective efficacy of the oral whole cell plus recombinant B subunit cholera vaccine in Peru. J Infect Dis 2000; 181: 1667-73.

6 Bhattacharya SK, Sur D, Ali M, et al. 5 year efficacy of a bivalent killed whole-cell oral cholera vaccine in Kolkata, India: a cluster-randomised, double-blind, placebo-controlled trial. Lancet Infect Dis 2013; 13: 1050-56.

7 Luquero FJ, Grout L, Ciglenecki I, et al. Use of Vibrio cholerae vaccine in an outbreak in Guinea. N Engl J Med 2014; 370: 2111-20.

8 Ivers LC, Hilaire IJ, Teng JE, et al. Effectiveness of reactive oral cholera vaccination in rural Haiti: a case-control study and bias-indicator analysis. Lancet Glob Health 2015; 3: e162-68.

9 van Loon FPL, Clemens JD, Chakraborty J, et al. Field trial of inactivated oral cholera vaccines in Bangladesh: results from 5 years of follow-up. Vaccine 1996; 14: 162-66.

10 Clemens JD, Sack DA, Harris JR, et al. Field trial of oral cholera vaccines in Bangladesh. Lancet 1986; 328: 124-27.

11 Parker LA, Rumunu J, Jamet C, et al. Adapting to the global shortage of cholera vaccines: targeted single dose cholera vaccine in respons to an outbreak in South Sudan. Lancet Infect Dis 2017; 17: e123-27.

12 WHO. Oral cholera vaccine stockpile. 2016; published online May 17. http://www.who.int/cholera/vaccines/Briefing_OCV_ stockpile.pdf?ua=1 (accessed Oct 31, 2016).

13 Valneva Products. Cholera vaccine. http://www.valneva.com/en/ products/dukoral (accessed Feb 6, 2017).

14 Ali M, Nelson AR, Lopez AL, Sack DA. Updated global burden of cholera in endemic countries. PLoS Negl Trop Dis 2015; 9: e0003832

15 Desai SN, Pezzoli L, Martin S, et al. A second affordable oral cholera vaccine: implications for the global vaccine stockpile. Lancet Glob Health 2016; 4: e223-24.

16 Elizabeth Halloran M, Longini IM Jr, Struchiner CJ. Design and analysis of vaccine studies. New York: Springer Science and Business Media, 2009: 31-32.

17 Higgins JPT, Green S. Cochrane handbook for systematic reviews of interventions. http://handbook.cochrane.org/ (accessed July 5, 2017).

18 Sidik K, Jonkman JN. A comparison of heterogeneity variance estimators in combining results of studies. Stat Med 2007; 26: 1964-81

19 Viechtbauer W, Wolfgang V. Conducting Meta-Analyses in R with the metafor Package. J Stat Softw 2010; 36: 1-48.

20 Raudenbush SW. Magnitude of teacher expectancy effects on pupil IQ as a function of the credibility of expectancy induction: A synthesis of findings from 18 experiments. J Educ Psychol 1984; 76: 85.

21 Sanchez JL, Hayashi KE, Kruger HF, et al. Immunological respons to Vibrio chderae $\mathrm{O} 1$ infection and an oral cholera vaccine among Peruvians. Trans R Soc Trop Med Hyg 1995; 89: 542-45.

22 Sévère $K$, Rouzier V, Anglade SB, et al. Effectiveness of oral choler vaccine in Haiti: 37-month follow-up. Am J Trop Med Hyg 2016; 94: $1136-42$.

23 Anh DD, Lopez AL, Thiem VD, et al. Use of oral cholera vaccines in an outbreak in Vietnam: a case control study. PLoS Negl Trop Dis 2011; 5: e1006.

24 Thiem VD, Deen JL, von Seidlein L, et al. Long-term effectiveness against cholera of oral killed whole-cell vaccine produced in Vietnam. Vaccine 2006; 24: 4297-303.

25 Sanchez JL, Vasquez B, Begue RE, et al. Protective efficacy of oral whole-cell/recombinant-B-subunit cholera vaccine in Peruvian military recruits. Lancet 1994; 344: 1273-76.
26 Trach DD, Clemens JD, Ke NT, et al. Field trial of a locally produced, killed, oral cholera vaccine in Vietnam. Lancet 1997; 349: 231-35.

27 Qadri F, Ali M, Chowdhury F, et al. Feasibility and effectiveness of oral cholera vaccine in an urban endemic setting in Bangladesh: a cluster randomised open-label trial. Lancet 2015; 386: 1362-71.

28 Qadri F, Firdausi Q, Wierzba TF, et al. Efficacy of a single-dose, inactivated oral cholera vaccine in Bangladesh. N Engl J Med 2016; 374: 1723-32.

29 Sur D, Lopez AL, Kanungo S, et al. Efficacy and safety of a modified killed-whole-cell oral cholera vaccine in India: an interim analysis of a cluster-randomised, double-blind, placebo-controlled trial. Lancet 2009; 374: 1694-702.

30 Clemens JD, Sack DA, Harris JR, et al. Field trial of oral cholera vaccines in Bangladesh: results from three-year follow-up. Lancet 1990; 335: 270-73.

31 Sur D, Kanungo S, Sah B, et al. Efficacy of a low-cost, inactivated whole-cell oral cholera vaccine: results from 3 years of follow-up of a randomized, controlled trial. PLoS Negl Trop Dis 2011; 5: e1289.

32 Clemens JD, Harris JR, Sack DA, et al. Field trial of oral cholera vaccines in Bangladesh: results of one year of follow-up. J Infect Dis $1988 ; 158: 60-69$.

33 Clemens JD, Sack DA, Rao MR, et al. Evidence that inactivated oral cholera vaccines both prevent and mitigate Vibrio cholerae $\mathrm{O} 1$ infections in a cholera-endemic area. J Infect Dis 1992; 166: 1029-34.

34 Khatib AM, Ali M, von Seidlein L, et al. Effectiveness of an oral cholera vaccine in Zanzibar. findings from a mass vaccination campaign and observational cohort study. Lancet Infect Dis 2012; 12: 837-44.

35 Lucas ME, Deen JL, von Seidlein L, et al. Effectiveness of mass oral cholera vaccination in Beira, Mozambique. $N$ Engl J Med 2005; 352: 757-67.

36 Wierzba TF, Kar SK, Mogasale VV, et al. Effectiveness of an oral cholera vaccine campaign to prevent clinically-significant cholera in Odisha State, India. Vaccine 2015; 33: 2463-69.

37 Azman AS, Parker LA, Rumunu J, et al. Effectiveness of one dose of oral cholera vaccine in response to an outbreak: a case-cohort study. Lancet Glob Health 2016; 4: e856-63.

38 Reuters. Haiti opens a drive to vaccinate 820,000 as cholera flares. Nov 9, 2016. http://www.nytimes.com/2016/11/10/world/americas haiti-cholera-hurricane-matthew.html (accessed Nov 11, 2016).

39 Kupferschmidt K. Cholera vaccine faces major test in war-torn Yemen. Washington DC: American Association for the Advancement of Science. June 28, 2017. http://www.sciencemag. org/news/2017/06/cholera-vaccine-faces-major-test-war-torn-yemen. (accessed July 11, 2017).

40 Qadri F, Bhuiyan TR, Sack DA, Svennerholm AM. Immune responses and protection in children in developing countries induced by oral vaccines. Vaccine 2013; 31: 452-60.

41 Dimitrov DT, Troeger C, Halloran ME, Longini IM, Chao DL. Comparative effectiveness of different strategies of oral cholera vaccination in bangladesh: a modeling study. PLOS Negl Trop Dis 2014; 8: e3343.

42 Anderson RM, May RM. Infectious diseases of humans: dynamics and control. Oxford: Oxford University Press, 1991.

43 Clemens JD, Sack DA, Ivanoff B. Misleading negative findings in a field trial of killed, oral cholera vaccine in Peru. J Infect Dis 2001; 183: 1306-09.

44 Sinclair D, Abba K, Zaman K, Qadri F, Graves PM. Oral vaccines for preventing cholera. Cochrane Database Syst Rev 2011. 3: CD008603. 
Single-Dose Cholera Vaccine in Response to an Outbreak in Zambia.

New England Journal of Medecine. 2018 08;378(6):577-9. 



\section{Cor $r$ espondence}

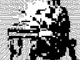

\section{Single-Dose Cholera Vaccine in Response to an Outbreak in Zembia}

To the Eifitor: Killedord doleravaine(OOA) are part of the standard response pakage to a chderaoutbreak, atthough thetwo doseregimen tients with cholera ${ }^{5}$ We asortained vacination of vacines that has been prequelified by the status by meens of strutured interviens using World Heath Organizetion (WHO) poses chet- photograps of OOS, and veified the informa lenges to timdy and efficient reative vacination tion with the use of vacination cards, when carpaigns. Peort data suggt that the first avalade Wecaladad thevacine ffectiveness doseane provides shorttemprotection, simila to that of two doses, which may lagdy dic tate the ffect of OOS dring epiderios ${ }^{24}$

A chdera outbrek wes detected in Lusaka, Zantia inFetruery 2016 a ater aperiod of 4 yers without areported case of dholera Anemegency reactive veccintion campaign was implemented in April 2016, targeting more then 500,000 pesons who wereat high risk for cholerain Luska (population, >2 million persons). The Ministry of Health, with support from Medecins sans Frontièes and the $\mathrm{W} H \mathrm{Q}$, dajoded to implement a singledose campaign to qull the epideric rapidy, in view of the insufficient number of vexcine doses that were avalade in the glode stodpile to complete a two-dose campaign In Deoertbe 2016, when morechses becameacilades a seound round of vaccintion wes org nized and the second vacine dose wes offered to pasons at risk.

Wb conducted a matched case-control study to qantify the shortterm effectiveness of a singledose OCV regimen (Shanchd) between April 25, 2016, and Ine 15, 2016. Thestudy wes aproved by two institutiond review boerds and written informed consent wes obtained fromal the participents (se the Spplementary Appendx, aciade with the full text of this lette a NEMorg). Cases of cholera were confirmed by mens of alture polymerasechainreation as say, or both Age and sexmatched controlswere selected from among the neightors of case as (1-odts ratio) × 100 using condiond logistic regression Wb also conduted a biasindictor stud indving persons with rondhderadantee and matched controls.

Weerrdled66persons with oonfirmed cholera and $\mathbf{3 3 0}$ matched controls. Veccintion with a singledose wes associated with significant protection in both the crude and afusted andyses (effectiveness in the adusted analysis, $889 \%$ $9 F \%$ corfidenceinterva, 427 to $97.8, P=0009$ ) (Tate 1). The biasindcator andysis induded 145 persons with noncholera dartea and 725 matched contrds In that andysis, we found that

\begin{tabular}{|ll|}
\hline \hline 57 & \multicolumn{1}{c|}{ this week's I etters } \\
& $\begin{array}{l}\text { Single-Dose Cholera Vaccine in Response } \\
\text { toan Outbreak in Zambia }\end{array}$ \\
579 & $\begin{array}{l}\text { ACEInhibitorsand Statinsin Addlescents } \\
\text { with Type 1 Diabetes }\end{array}$ \\
581 & $\begin{array}{l}\text { Effects of Spaceflight on Astronaut Brain } \\
\text { Structure }\end{array}$ \\
583 & $\begin{array}{l}\text { Nutritional Management of ChronicKidney } \\
\text { Disease }\end{array}$ \\
585 & AcuteGraft-versus-Host Disease \\
587 & Maternal Health in the United States \\
\hline
\end{tabular}




\begin{tabular}{|c|c|c|c|c|c|c|}
\hline \multirow[t]{2}{*}{ Analysis } & Controls & $\begin{array}{c}\text { Case } \\
\text { Patients }\end{array}$ & $\begin{array}{c}\text { Crude Estimate } \\
\text { of Vaccine Effectiveness } \\
(95 \% \mathrm{Cl})\end{array}$ & $\begin{array}{c}\text { P } \\
\text { Value }\end{array}$ & $\begin{array}{c}\text { Adjusted Estimate } \\
\text { of Vaccine Effectiveness } \\
\text { (95\% Cl) }\end{array}$ & $\begin{array}{c}\text { P } \\
\text { Value }\end{array}$ \\
\hline & \multicolumn{2}{|c|}{ no. of participants (\%) } & $\%$ & & $\%$ & \\
\hline \multicolumn{7}{|l|}{ Main vaccine-effectiveness analysis } \\
\hline Total no. of participants & 330 & 66 & & & & \\
\hline Unvaccinated participants & $286(87)$ & $63(95)$ & Reference & & Reference & \\
\hline Participants vaccinated with single dose $\dot{\gamma}$ & $44(13)$ & $3(5)$ & 84.7 (27.0 to 96.6$)$ & 0.02 & $88.9(42.7$ to 97.8$) \dagger$ & 0.009 \\
\hline \multicolumn{7}{|l|}{ Bias-indicator analysis } \\
\hline Total no. of participants & 725 & 145 & & & & \\
\hline Unvaccinated participants & $499(69)$ & $106(73)$ & Reference & & Reference & \\
\hline Participants vaccinated with single dose $\dot{\gamma}$ & $226(31)$ & $39(27)$ & $22.8(-19.7$ to 57.5$)$ & 0.20 & $24.6(-27.5$ to 55.5$) 5$ & 0.29 \\
\hline
\end{tabular}

* In the main vaccine-effectiveness analysis, a person with a confirmed case of cholera was defined as any patient with acute watery diarrhea (at least three watery stools in a 24-hour period) with a positive culture, polymerase-chain-reaction (PCR) assay results, or both for Vibrio cholerae serogroup $\mathrm{Ol}$. In the bias-indicator analysis, a person with noncholera diarrhea was defined as a patient with a suspected case of cholera but with a negative cholera culture and PCR assay results. Inclusion and exclusion criteria for the controls and case patients, as well as the laboratory methods for confirmation of cholera, are provided in the Supplementary Appendix.

$\dagger$ Study staff asked participants during a structured in-person interview at their home whether they had been vaccinated. We considered a person to be vaccinated if the person reported having received the vaccine and if the date of diarrhea onset (or, for controls, the date of diarrhea onset in the matched case patient) was at least 7 days after the receipt of vaccine. For persons who reported having been vaccinated, the interviewer asked to see the vaccination card and took a photograph of it, if available. In the main analyses, vaccination status was based on oral reporting.

$\Varangle$ The crude and adjusted estimates of vaccine effectiveness were obtained with the use of conditional logistic regression. The final adjusted model included variables that were potentially associated with the outcome and with exposure to cholera $(P<0.20)$ and those that modified the vaccine effectiveness by more than $5 \%$ in the bivariate model (i.e., sharing the source of drinking water with a person with cholera or having a household member with cholera in the previous week). Living in a vaccination area was included as a stratification variable in the regression model.

The selection of variables for inclusion in the final regression model of the bias-indicator analysis was done with the use of the same criteria that were used in the main analysis. In the bias-indicator analysis, the vaccine effectiveness estimate was adjusted by frequencies of having treated drinking water and having soap available at home. Living in a vaccination area was included as a stratification variable in the regres-
sion model.

the odds of vaccination did not vary significantly between the two groups in the crude or adjusted analyses ( $P=0.29$ in the adjusted analysis), which suggests the absence of selection bias.

Our results show the short-term effectiveness of a single dose of OCV delivered during an outbreak. Previous studies measuring the protection provided by a single dose of OCV were conducted in areas with recent exposure to cholera, which raises the possibility that single-dose regimens might act to boost natural immunity. ${ }^{2,3,5}$ Our results indicate that single-dose regimens provide protection in populations with less exposure to cholera, such as those in Lusaka and much of sub-Saharan Africa, where multiyear lull periods are punctuated by explosive outbreaks. Although additional work is needed to determine the protection provided by a single-dose vaccine in young children and persons not previ- ously exposed to cholera, the duration of protection provided by a single-dose regimen, and an appropriate interval for the administration of a second dose, our results support the use of singledose regimens to improve responses during a cholera outbreak.

Eva Ferreras, M.Pharm., M.Sc.

Epicentre

Paris, France

Elizabeth Chizema-Kawesha, M.D., M.P.H.

Ministry of Health

Lusaka, Zambia

Alexandre Blake, M.D.

Epicentre

Paris, France

Orbrie Chewe, B.Sc.

Ministry of Health

Lusaka, Zambia 
John Mwaba, M.Sc.

University Teaching Hospital

Lusaka, Zambia

Gideon Zulu, M.P.H.

Ministry of Health

Lusaka, Zambia

Marc Poncin, Ph.D.

Médecins sans Frontières

Geneva, Switzerland

Ankur Rakesh, M.B., B.S., M.P.H.

Anne-Laure Page, Ph.D.

Epicentre

Paris, France

Savina Stoitsova, M.Sc.

European Program for Intervention Epidemiology Training Stockholm, Sweden

Caroline Voute, M.P.H.

Florent Uzzeni, M.D.

Hugues Robert, B.Arch., I.D.H.A.

Micaela Serafini, M.D.

Médecins sans Frontières

Geneva, Switzerland

Belem Matapo, M.Sc.

World Health Organization

Lusaka, Zambia

Jose-Marla Eiros, M.D., Ph.D.

University of Valladolid

Valladolid, Spain

Marie-Laure Quilici, Ph.D.

Institut Pasteur

Paris, France

Lorenzo Pezzoli, D.V.M., Ph.D.

World Health Organization

Geneva, Switzerland
Andrew S. Azman, Ph.D.

Johns Hopkins Bloomberg School of Public Health

Baltimore, MD

Sandra Cohuet, M.D., M.P.H.

Epicentre

Paris, France

Iza Ciglenecki, M.D.

Médecins sans Frontières

Geneva, Switzerland

Kennedy Malama, M.D., M.P.H.

Ministry of Health

Lusaka, Zambia

Francisco J. Luquero, M.D., Ph.D.

Epicentre

Paris, France

francisco.luquero@epicentre.msf.org

Supported by Médecins sans Frontières, by a grant to Drs. Azman and Luquero from the DOVE project at Johns Hopkins Eloomberg School of Public Health, and by Institut Pasteur.

Disclosure forms provided by the authors are available with the full text of this letter at NEJM.org.

1. Martin S, Lopez AL, Bellos A, et a!. Postlicensure deploy. ment of oral cholera vaccines: a systematic review. Bull World Health Organ 2014:92:881-93.

2. Qadri F, Wierzba TF, Ali M, et al. Efficacy of a single-dose, inactivated oral cholera vaccine in Eangladesh. N Engl J Med 2016; 374:172:-32.

3. Azman AS, Parker LA, Rumunu J, et al. Effectiveness of one dose of oral cholera vaccine in response to an outbreak: a casecohort study. Lancet Glob Health 2016;4(11):e856-e863.

4. Azman AS, Luquero FJ, Ciglenecki I, Grais RF, Sack DA, Lessler J. The impact of a one-dose versus two-dose oral cholera vaccine regimen in outbreak settings: a modeling study. PLoS Med 2015;12(8):e1001867.

5. Luquero FJ, Grout L, Ciglenecki I, et al. Use of Vibrio cholerae vaccine in an outbreak in Guinea. N Engl J Med 2014;370:2111-20.

DOt: 10.1056/NEJMc1711583 


\section{Supplementary Appendix}

This appendix has been provided by the authors to give readers additional information about their work.

Supplement to: Ferreras E, Chizema-Kawesha E, Blake A, et al. Single-dose cholera vaccine in response to an outbreak in Zambia. N Engl J Med 2018;378:577-9. DOI: 10.1056/NEJMc1711583 
Table of content

1. Description of the 2016 cholera epidemic in Lusaka .......................................................... 2

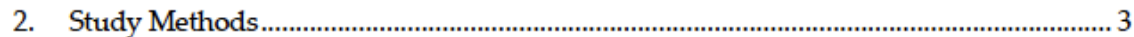

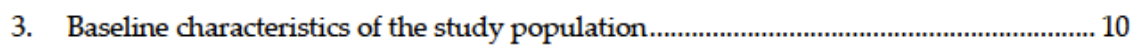

4. Stratified results by age, severity and vaccinated area .................................................... 13

5. Model selection for the multivariate analysis................................................................... 14

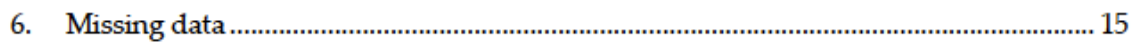

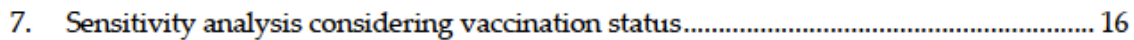

Supplement references....................................................................................................... 18 


\section{Description of the 2016 cholera epidemic in Lusaka}

Cholera is endemic in Zambia, and Lusaka, the capital, has experienced long periods with recurrent annual epidemics (from 1991 to 1999 and from 2003 to 2011) with up to 10,000 reported cases per year. ${ }^{1}$ However, no cholera cases were reported between 2012 and 2016. The historical risk of cholera within Lusaka is not homogenous, with townships in the Western part of the city typically suffering the largest burden of disease. These areas with historically high risk represent a population of around 500,000 people and are comprised of those with the lowest access to safe water and sanitation in the city. ${ }^{2}$

In 2016, the first confirmed case of cholera in Lusaka was reported on February $4^{\text {th }}$ (week 5) from Kanyama. Laboratory analyses identified that the circulating strain was Vibrio Cholera O1 Ogawa.

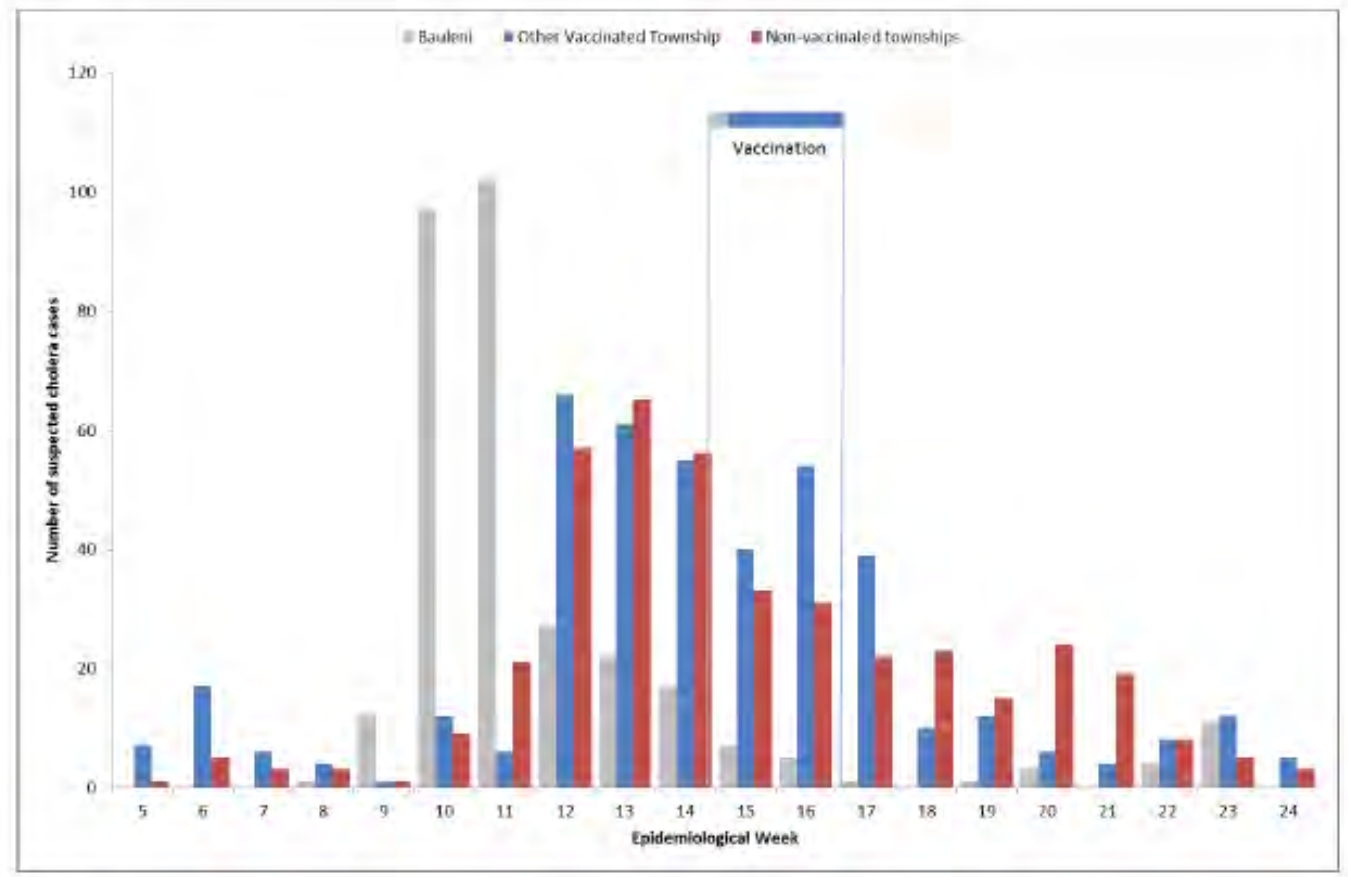

Figure S1. Suspected cholera cases by week in Bauleni Township (vaccinated area, grey), in other vaccinated areas excluding Bauleni (blue) and in areas not targeted for vaccination (red). Adapted from Poncin et al. ${ }^{3}$ 
A sharp increase (from 14 to 118 suspected cases per week) occurred during week 10, with cases primarily reported from Bauleni ( $82 \%$ of the cases in week 10). Overall, 1139 suspected cholera cases and 20 deaths were reported. The case fatality rate (CFR) was $1.76 \%$ although after excluding those dead on arrival, the CFR was $0.88 \%$ among hospitalized cases. The highest overall number of reported cases was observed during week 12, with 150 suspected cholera cases. The outbreak was declared officially over on June 15 th 2016 (week 24).

The oral cholera vaccine (OCV) campaign started on April 9 $9^{\text {th }}$ (week 14), when the peak in Bauleni was already reached, and finished on April 23 $3^{\text {rd }}$ (week 16). Four areas (Bauleni, Kanyama, George and Chawama) were targeted for the vaccination campaign based on either having the highest attack rates in the current epidemic, or being areas historically known to be prone to cholera. All the individuals 12 months old residing in these townships were targeted for vaccination. A total of 424,100 doses were administered, resulting in $73.4 \%$ administrative coverage in the areas targeted for vaccination. ${ }^{3}$ After the vaccination campaign, the epidemic continued to spread in some areas considered at lower risk and not targeted with vaccine.

\section{Study Methods}

\section{Study oversight}

This study was funded by Médecins Sans Frontières (MSF). The study protocol was approved by the Ethical Review Boards of the University of Zambia and the Johns Hopkins Bloomberg School of Public Health (USA). Written informed consent was obtained from participants or their parents/guardians. Privacy and confidentiality of the data collected from participants was ensured both during and after the study. 


\section{Cholera surveillance}

The surveillance system was reinforced with the use of standardized line-lists and case definitions in five cholera treatment centers located in Kanyama, Bauleni, Chawama, Matero and George from April 14 $14^{\text {th }}, 2016$ until the end of the outbreak (Figure S2). These clinics provided free treatment and served all the high-risk areas in Lusaka. Stool samples from all suspected cases recruited in the study were collected and sent to Kanyama clinic laboratory for microbiological testing (see laboratory methods below) at the University Teaching Hospital (Lusaka, Zambia) and Institut Pasteur (Paris, France), using previously described methods (see more details in the laboratory methods section).

\section{Study design}

We used a matched case-control design both to estimate the vaccine effectiveness and to assess potential biases related to differential health seeking behavior between vaccinated and nonvaccinated individuals (bias-indicator analysis). The vaccine effectiveness analyses use confirmed cholera cases as 'cases' and the bias indicator analysis use non-cholera diarrhea cases as 'cases' along with their matched controls. Because the vaccine was not expected to provide protection against non-cholera diarrhea, in the absence of bias, we expected a null association between vaccination and non-cholera diarrhea in the bias-indicator case-control study.

\section{Definition and selection of cases}

A suspected cholera case was any patient with acute watery diarrhea (at least three watery stools in a 24-hour period). All suspected cholera cases admitted in any of the study health

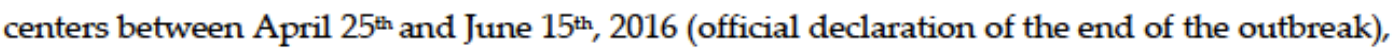
were eligible to be included in the study if she/he provided consent and fulfilled the 
following criteria: resided in the study area since April $9^{\text {th }}, 2016$ (first day of vaccination); older than 12 months; diarrhea started after April 9 th, 2016 ; and her/his residence could be located by the study team after discharge. Confirmed cholera cases were suspected cholera cases with a positive culture and/or polymerase chain reaction (PCR) result. Non-cholera diarrhea cases were defined as suspected cases with negative cholera culture and PCR results.

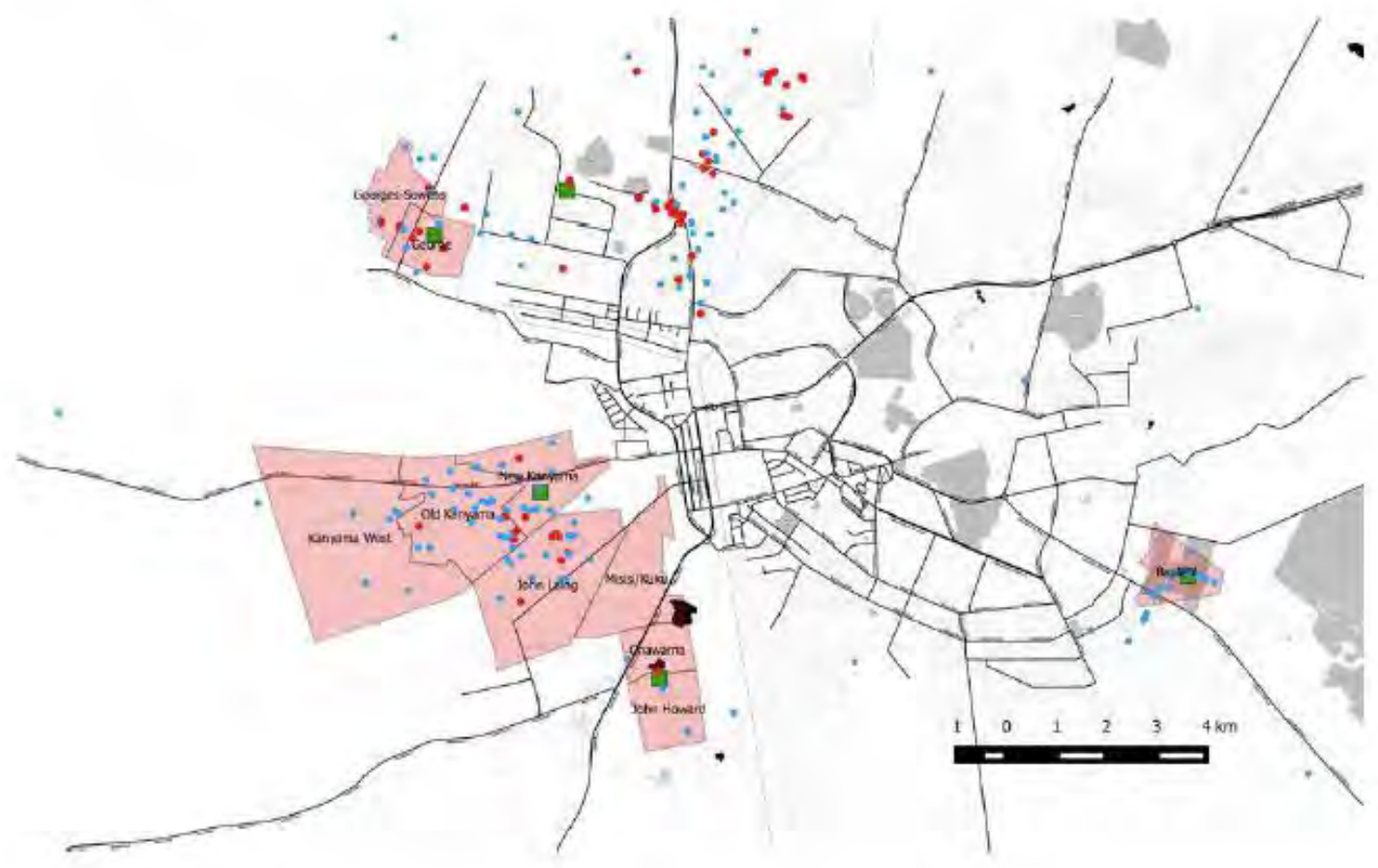

Figure S2: Map of confirmed cholera cases (red dots) and non-cholera suspected cases (blue dots) and study clinics (green squares). Vaccinated townships in Lusaka colored as light-red areas.

\section{Definition and selection of controls}

Five neighbor-controls were selected for each suspected cholera case and included in the primary and bias indicator analyses. A neighbor of the same sex and within the same age group (1-4, 5- 9, 10-19, 20-29, 30-39, and $\geq 40$ years) as the suspected cholera case was eligible 
to be a control if she/he: resided in the study area since April $9^{\text {th }}, 2016$; was older than 12 months; had not sought treatment for diarrhea at a health center between January 1st, 2016 and the date of onset of the matched case's diarrhea; and would have sought treatment in a health center if severe, watery diarrhea had developed.

\section{Ascertainment of vaccination status and potentially confounding variables}

We considered an individual vaccinated if she/he reported to have received the vaccine and her/his diarrhea onset date (or, for controls, the diarrhea onset date of her/his respective case) was at least 7 days after taking the vaccine. Study staff asked participants during a structured in-person interview at their household whether they had been vaccinated. The interviewers showed a picture of a vaccine vial and of an adult taking the vaccine, and described details of the vaccination campaign, including dates and locations, to minimize confusion with other antigens. For those reporting to have been vaccinated, the interviewer asked to see her/his vaccination card and took a photograph, if available. In the main analyses, vaccination status was based on oral reporting.

Clinical, demographic, socioeconomic, and environmental variables were collected through electronic questionnaires using Kobo Toolbox software 1.4.8 (Cambridge, MA, USA).

\section{Laboratory methods}

A stool sample was collected from all suspected cases in an unused and unchlorinated container. Fresh stools were used to perform culture and rapid diagnostic test (RDT) on site, and two drops were placed on Whatman 903 filter paper for subsequent PCR testing. In addition, about $50 \mathrm{mg}$ of stool collected with a swab were inoculated in $5 \mathrm{ml}$ of alkaline 
peptone water $(\mathrm{APW})$. After incubation at $37^{\circ} \mathrm{C}$ for $4-6 \mathrm{~h}$, this enrichment medium was used to repeat all three procedures (culture, RDT and inoculation of filter paper) (Figure S3).

Rapid diagnostic tests (direct in stool and after enrichment in APW) were performed on-site by study laboratory technicians with the purpose of having a real-time monitoring of the inclusions in the study, but were not used to define the study outcomes considering the very limited information about the performance of SD Bioline RDT. Only culture and PCR were used to define confirmed cholera cases and non-cholera watery diarrhea cases.

Culture was performed at Kanyama clinic laboratory under the supervision of University Teaching Hospital (UTH). For each specimen, two plates of Thiosulfate-Citrate-Bile-Sucrose (TCBS) agar were streaked with the fresh stool and enrichment medium, respectively. Colonies suggestive of $V$. cholerae were then sub-cultured on Mueller-Hinton (MH) agar. Colonies grown on $\mathrm{MH}$ plates were further serotyped using polyvalent $\mathrm{O} 1, \mathrm{O} 139, \mathrm{O} 1$ Inaba and $\mathrm{O} 1$ Ogawa antisera.

PCR was performed at UTH, and in parallel at Institut Pasteur using specimen stored on dried Whatman 903 filter paper. One circle containing two drops of fresh stool was placed in a microtube and rehydrated with $150 \mu \mathrm{L}$ sterile water. $200 \mu \mathrm{L}$ of $2 \%$ Chelex solution was then added and the sample was vortexed at high speed, boiled for 8 minutes and centrifuged for 2 minutes. PCR was performed on $2 \mu \mathrm{L}$ of the supernatant to detect an intergenic spacer region specific of $V$. cholerae species (ISR gene). ${ }^{\sharp}$ On samples positive for $V$. cholerae, the $r f b$ gene was amplified for the identification of V. cholerae serogroups $\mathrm{O} 1$ and $\mathrm{O} 139$, as described by Hoshino. ${ }^{5}$ On negative samples, the PCR for $V$. cholerae species was repeated on $4 \mu \mathrm{L}$. If 
negative again, a 16S RNA PCR was performed to assess the presence of DNA and/or PCR inhibitors.

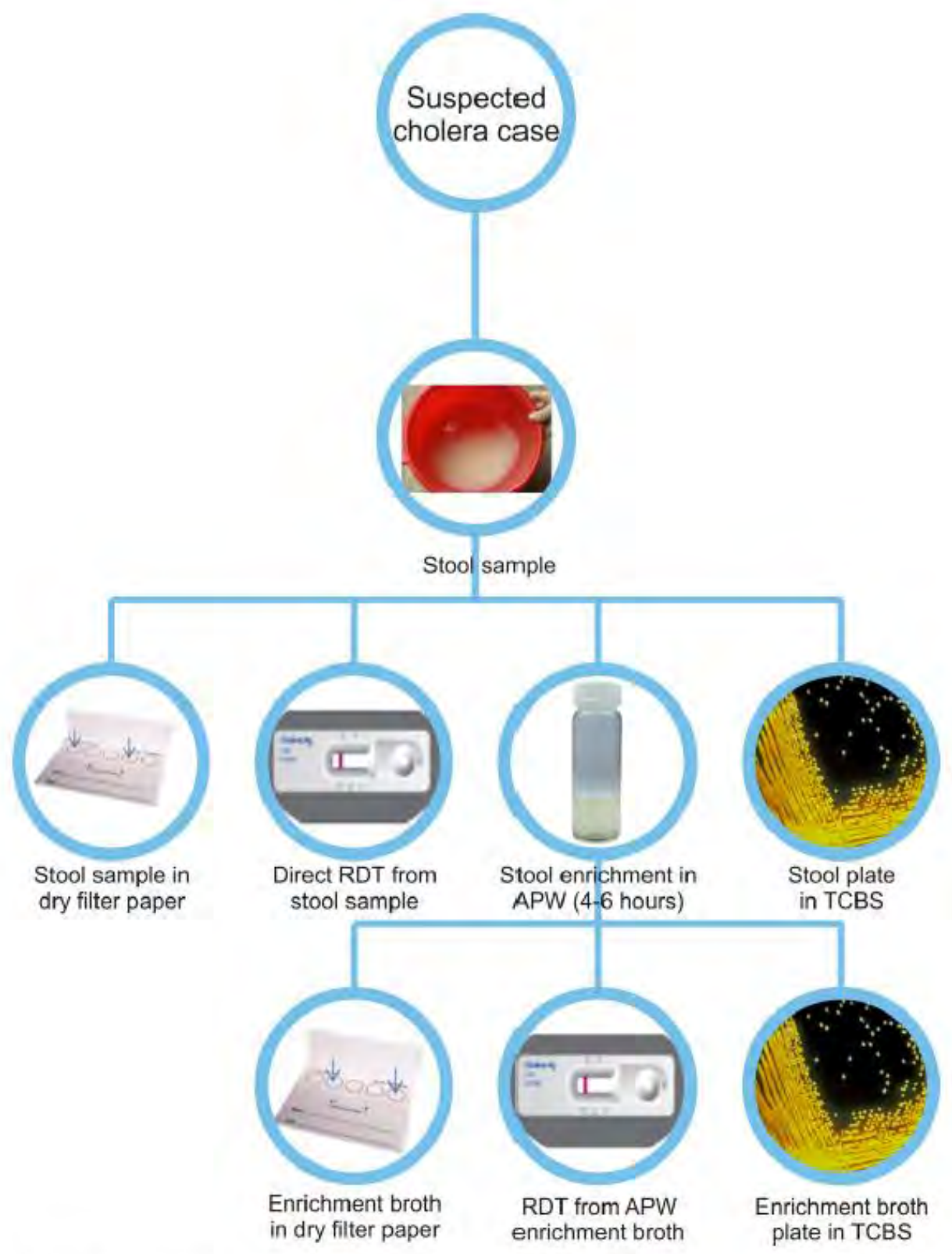

Figure S3. Description of the different laboratory procedures: culture, rapid tests and PCR analyses (from dry filter papers) 


\section{Statistical analysis}

The primary analysis assessed the protection conferred by the receipt of one dose of vaccine against confirmed cholera. We calculated that 115 cases and 575 controls (ratio of 1:5) would be needed to have $80 \%$ power to detect vaccine effectiveness of $50 \%$ with an alpha (type-I error) of $5 \%$.

We compared the odds of vaccination between confirmed cholera cases and matched controls using univariate and multivariate conditional logistic regression models to account for the matched design. We calculated the vaccine effectiveness as (1-odds ratio) $\times 100$. We also conducted stratified analyses to explore major interactions (by age, disease severity and residing in an area targeted for vaccination). Areas targeted and non-targeted for vaccination were considered to have potentially different baseline risk of exposure to cholera and were included as stratification variables in the multivariate models.

We compared demographic, environmental, and socioeconomic factors between confirmed cholera cases and their matched controls with conditional logistic regression to help assess their potential as confounders of vaccine effectiveness (see Multivariate model selection below for more details). We considered variables potentially associated with the outcome and the exposure $(\mathrm{P}<0.2)$ and those that modified the vaccine effectiveness by more than $5 \%$ in the bivariate models (including vaccination status) as potential confounders for inclusion in the final adjusted model. All P-values and 95\% confidence intervals were two-sided and considered any p-values less than 0.05 to be statistically significant. We used $\mathrm{R}$ statistical software (version 3.2.3) and the survival package for the main analyses. 
3. Baseline characteristics of the study population

From April $25^{\text {th }}$ to June $15^{\text {th }}, 2016,251$ suspected cholera cases were admitted and treated at health centers in the study area (Figure S2) and 211 of these suspected cholera cases along with 1055 controls were included in the study (Figure S4).

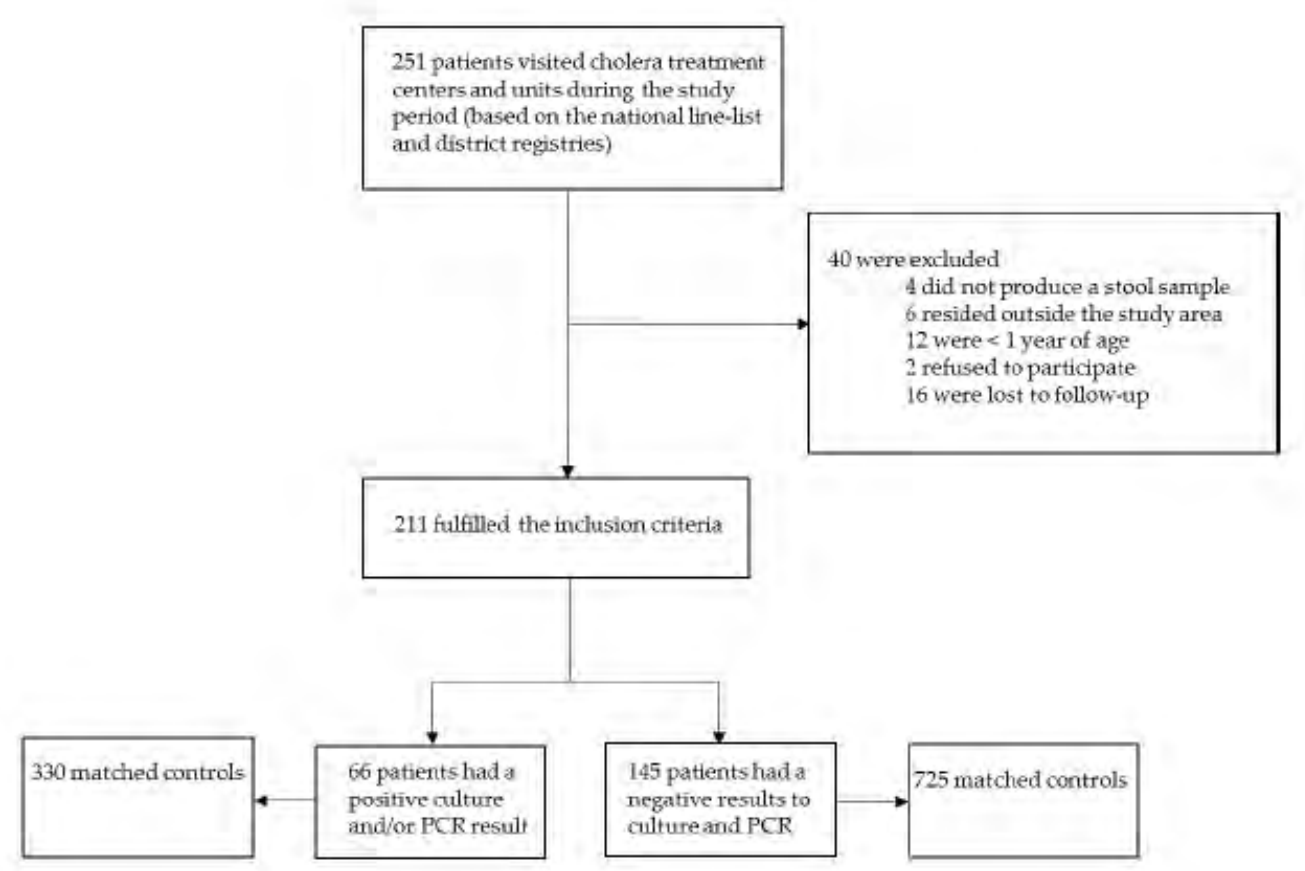

Figure S4. Study flowchart

The mean age of the suspected cholera cases included in the study was 21.6 years (standard deviation: 18.2), with $28 \%(n=59)$ of them being children under 5 years. Half $(50 \%)$ of the suspected cases were female, although among confirmed cases, $42 \%$ were female (Table S1). Overall, $39 \%(n=83)$ of the suspected cholera cases sought care on the day of symptom onset 
and $82 \%$ of the cases had some degree of dehydration at admission (55\% were severely dehydrated). Severe dehydration was more common among confirmed cholera cases than among non-cholera diarrhea cases ( $89 \%$ vs $39 \%$; Table S1).

Among the 211 suspected cholera cases included in study, $66(31 \%)$ had positive culture and/or PCR results for $V$. cholerae $\mathrm{O} 1$. All isolates were $V$. cholerae $\mathrm{O} 1$ serotype Ogawa. In addition, 145 suspected cholera cases had negative culture and PCR results and were included in the bias indicator analysis (Figure S4).

Table S1: Clinical presentation and treatment of suspected cholera cases by culture confirmation.

\begin{tabular}{|lcc|}
\hline & $\begin{array}{r}\text { Non-cholera cases } \\
\text { Female sex }\end{array}$ & Confirmed cholera cases \\
Mean age (standard deviation) & $77(53.1)$ & $\mathrm{n}=66(\%)$ \\
Dehydration stage at presentation & $21.1(19.1)$ & $28(42.4)$ \\
A (no dehydration) & $37(25.5)$ & $0(0.0)$ \\
B (mild) & $51(35.2)$ & $7(10.6)$ \\
C (severe) & $56(38.6)$ & $59(89.4)$ \\
Antibiotics within 2 days before admission & $12(8.3)$ & $8(12.1)$ \\
\hline
\end{tabular}

Cholera confirmed cases were more likely than controls to have had at least one household member with cholera in the week prior to the interview, to share drinking water with cholera patient in the week prior to the interview, to use a flooded latrine and to share a latrine with someone with diarrhea in the week prior to the interview (Table S2). 
Table S2: Characteristics of confirmed cholera cases and controls.

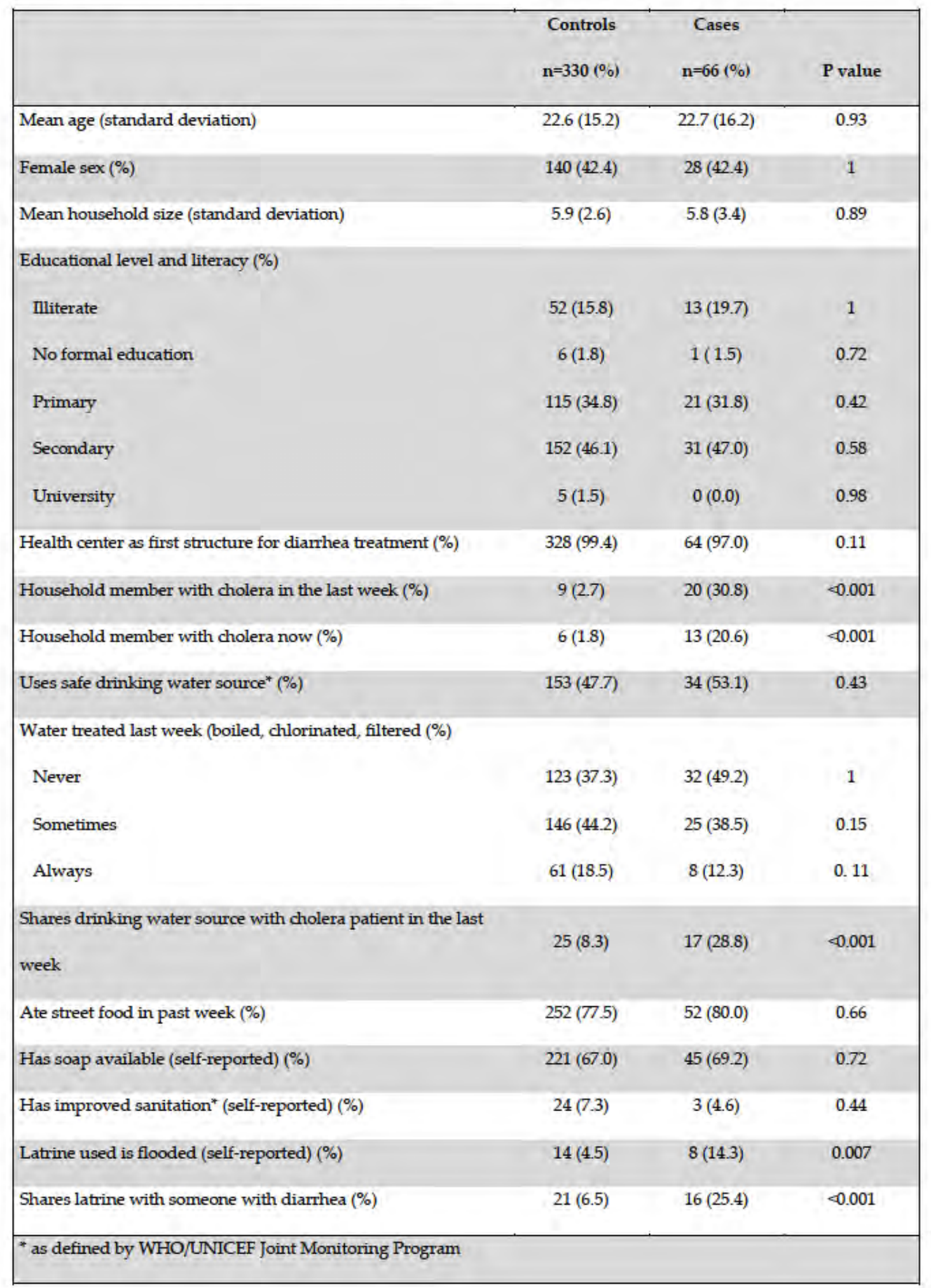




\section{Stratified results by age, severity and vaccinated area}

In addition to the main analyses presented in the manuscript, we performed a series of stratified analyses to understand how estimates of effectiveness may vary by age, disease severity and geographic area. When we restricted analyses to include (1) only those 5 years and older, (2) only severely dehydrated cases or (3) only those residing in areas targeted for vaccination, we estimated similar levels of protection to that presented in the main analyses (Table S3). We did not enroll enough cases under five years old nor enough mild to moderately dehydrated cases to obtain stable estimates of the protection conferred by OCV in these important sub-populations (Table S3).

Table S3. Stratified analyses by age, severity and vaccinated area

\begin{tabular}{|c|c|c|c|c|c|c|c|}
\hline & controls & & cases & & VE & $95 \% \mathrm{CI}$ & P value \\
\hline & $\mathrm{N}$ & $(\%)$ & $\mathrm{N}$ & $(\%)$ & $\%$ & & \\
\hline \multicolumn{8}{|c|}{ Individuals 5 years old and above" } \\
\hline Unvaccinated & 231 & $(84.0)$ & 52 & $(94.5)$ & Ref & & \\
\hline Vaccinated & 44 & $(16.0)$ & 3 & $(5.5)$ & $84.3 \%$ & (25.3 to 98.9$)$ & 0.03 \\
\hline \multicolumn{8}{|c|}{ Severely dehydrated casest } \\
\hline Unvaccinated & 253 & $(87.2)$ & 57 & $(96.6)$ & Ref & & \\
\hline Vaccinated & 37 & $(12.8)$ & 2 & $(3.4)$ & $90.4 \%$ & $(22.7$ to 98.8$)$ & 0.03 \\
\hline \multicolumn{8}{|c|}{ Individuals residing in targeted areas } \\
\hline \multicolumn{8}{|l|}{ for vaccination } \\
\hline Unvaccinated & 62 & $(59.6)$ & 18 & $(85.7)$ & Ref & & \\
\hline Vaccinated & 42 & $(40.4)$ & 3 & (14.3) & $84.0 \%$ & (25.2 to 96.6$)$ & 0.02 \\
\hline
\end{tabular}

* There were only 11 children under five years old with confirmed cholera. All under-five cases and the matchedcontrols were not vaccinated and this does not allow obtaining stable estimates of protection in this stratum. All except two of the confirmed under-five year old cases were recruited from non-targeted areas for vaccination, which explains the low exposure to vaccine in both cases and controls in this group.

t There were only 7 moderate cholera confirmed cases ( 1 vaccinated and 6 non-vaccinated cases; 6 discordant pairs in total for this group), which does not allow us to obtain stable estimates of protection in this stratum. 


\section{Model selection for the multivariate analysis}

The crude vaccine effectiveness estimates were obtained comparing the odds of vaccination between cases and controls (Table 1 in main paper). We explored the potential confounding effect of different well-known risk factors for cholera (Table S2) to obtain adjusted vaccine effectiveness estimates (Table 1 in main paper). We defined variables as possible confounders when they were associated with the outcome and with the exposure (vaccination status). We conservatively considered variables to be 'associated' when the pvalue for the variable in a univariate model (with the outcome or the exposure) was less than 0.2 . This analysis identified a single variable with potential of being a confounder in the relationship between cholera vaccine intake and case status: "share drinking water source with a cholera patient in the last week". This variable had P-values less than 0.2 when compared with the outcome $(\mathrm{P}<0.001)$ and with the vaccination status $(\mathrm{P}=0.15)$. In addition, we conducted conditional logistic regression models including the case-control status as the dependent variable, the vaccination status as the main exposure and each potential confounder to identify variables that modified the crude vaccine effectiveness estimate by more than $5 \%$. We developed one model for each variable included in Table S2, and following this procedure we identified as a possible confounder another variable: "household member with cholera in the last week". This variable modified the crude vaccine effectiveness from $85 \%$ to $92 \%$. The two potential confounders identified (share drinking water source with a cholera patient in the last week and household member with cholera in the last week) were likely measuring a similar dimension of the risk of getting cholera infection, which is reflected in a highly significant Fisher-exact test when exploring the association between these two variables across all participants $(\mathrm{P}<0.001)$. We decided to combine both variables in a single combined variable that considers those who had a 
household member with cholera in the previous week or shared the drinking water source with a cholera patient as 'exposed'. The final adjusted model includes this combined variable as a possible confounder. In addition, considering that the cases in main analysis could come from both targeted and not targeted areas for vaccination, which likely had different baseline risk of cholera, we decided included a binary 'vaccinated area' variable as a stratification variable in the conditional logistic regression model.

\section{Missing data}

The database did not contain any missing data for the outcome or the vaccination status.

Table S4 shows variables with missing data that were tested as possible confounders.

Table S4. Percentage of missing among variables tested as possible confounders.

\begin{tabular}{|lcc|}
\hline & $\begin{array}{c}\text { Controls } \\
\text { (n=330) }\end{array}$ & $\begin{array}{c}\text { Cases } \\
\text { (n=66) }\end{array}$ \\
\hline Household size & $0.0 \%$ & $1.5 \%$ \\
Educational level & $0.0 \%$ & $0.0 \%$ \\
Seeking care at health center for diarrhea & $0.0 \%$ & $0.0 \%$ \\
Household member with cholera now & $0.6 \%$ & $1.5 \%$ \\
Use safe drinking water source & $0.0 \%$ & $4.5 \%$ \\
Water treatment & $1.8 \%$ & $1.5 \%$ \\
Shares drinking water source with cholera patient & $0.0 \%$ & $1.5 \%$ \\
Ate street food in the past week & $9.1 \%$ & $10.6 \%$ \\
Had soap available (self-reported) & $1.5 \%$ & $1.5 \%$ \\
Had improved sanitation ${ }^{*}$ (self-reported) & $0.0 \%$ & $1.5 \%$ \\
Latrine used is flooded (self-reported) & $0.0 \%$ & $1.5 \%$ \\
Shares latrine with someone with diarrhea & $5.2 \%$ & $15.2 \%$ \\
\hline * as defined by WHO/UNICEF Joint Monitoring Program & $1.5 \%$ & $4.5 \%$ \\
\hline
\end{tabular}


The crude analysis was not affected by the missing data since the database did not contain any missing information for the outcome, the exposure or the matched set. For the multivariate analysis, the two variables identified as possible confounders contained missing data and we analyzed the possible influence of the missing data in the adjusted vaccine effectiveness estimates. We explored three different strategies to handle the missing values in the multivariate analysis: (i) removing the entries with missing values for any of the variables of interest, (ii) considering the missing data as a dummy variable, (iii) imputing the missing data using multiple imputation with chained equations (MICE). ${ }^{6,7}$ Following this process, we created 100 imputed data sets that were used for the multivariate analyses. Table S5 shows the adjusted vaccine effectiveness estimates for each strategy for both the primary and secondary analysis, respectively. In the main manuscript, we included the point estimate and the confidence intervals obtained with missing data imputed using MICE as the adjusted vaccine effectiveness.

Table S5. Adjusted vaccine effectiveness estimates considering different strategies to handle the missing data in the main matched case-control study.

\begin{tabular}{lccc}
\hline & Adjusted & & $95 \% \mathrm{CI}$ \\
& $\mathrm{VE}^{*}$ & \\
\hline Entries with missing data excluded & 86.5 & $(29.1$ to 97.4$)$ \\
Missing values as a dummy variable & 87.4 & $(30.9$ to 97.7$)$ \\
Multiple imputation of missing values & 88.9 & (42.7 to 97.8$)$ \\
\hline
\end{tabular}

* Vaccine effectiveness was adjusted by sharing the drinking water source with a cholera patient or having a household member with cholera in the previous week. Residing in an area targeted for vaccination was included as a stratification variable in the conditional logistic regression model.

\section{Sensitivity analysis considering vaccination status}

We assessed vaccine exposure through self-reporting, and verified vaccination through documentation of the vaccine card. Self-reported vaccination might be affected by a cholera 
episode and therefore might differ by case or control status, whereas lost vaccine cards might lead to underestimates of vaccination coverage. For the main analyses, we used the selfreported vaccination status. To assess the sensitivity of our results to this assumption, we estimated the vaccine effectiveness using two alternative vaccination classification schemes; (1) classifying those who reported to have been vaccinated without having a vaccination card as unvaccinated and (2) excluding those who reported to have been vaccinated without having a vaccination card (Table S6).

The estimates were stable when removing those without vaccination card, and slightly reduced when considering them as unvaccinated, however the small sample size reduced the precision of the vaccine effectiveness estimates.

Table S6. Sensitivity analysis on the vaccination status excluding individuals without card and considering individuals without card as unvaccinated

\begin{tabular}{|c|c|c|c|c|c|c|c|}
\hline & controls & & cases & & VE & $95 \% \mathrm{CI}$ & $P$ value \\
\hline & $\mathrm{N}$ & $(\%)$ & $\mathrm{N}$ & $(\%)$ & $\%$ & & \\
\hline \multicolumn{8}{|l|}{ Vaccination status } \\
\hline Unvaccinated & 286 & $(86.7)$ & 63 & $(95.5)$ & & & \\
\hline Vaccinated (with card) & 21 & $(6.4)$ & 2 & $(3.0)$ & & & \\
\hline Vaccinated (without card) & 23 & $(7.0)$ & 1 & (1.5) & & & \\
\hline \multicolumn{8}{|l|}{ Vaccinated without cards as vaccinated } \\
\hline Unvaccinated & 286 & $(86.7)$ & 63 & $(95.5)$ & Ref & & \\
\hline Vaccinated (with and without card) & 44 & (13.3) & 3 & $(4.5)$ & 84.7 & (27.0 to 96.6$)$ & 0.02 \\
\hline \multicolumn{8}{|c|}{ Vaccinated without cards as unvaccinated } \\
\hline Unvaccinated & 309 & (93.6) & 64 & $(97.0)$ & Ref & & \\
\hline Vaccinated (with card) & 21 & $(6.4)$ & 2 & $(3.0)$ & 62.9 & $(-93.4 \%$ to $92.9 \%)$ & 0.24 \\
\hline \multicolumn{8}{|l|}{ Vaccinated without cards excluded } \\
\hline Unvaccinated & 267 & $(92.7)$ & 63 & (96.9) & Ref & & \\
\hline Vaccinated (with card) & 21 & (7.3) & 2 & (3.1) & 83.0 & $(-52.0$ to 98.1$)$ & 0.11 \\
\hline
\end{tabular}




\section{Supplement references}

1. ZambiaCountryProfile2011 [Internet]. [cited 2016 Oct 28]. Available from: http://www.who.int/cholera/countries/ZambiaCountryProfile2011.pdf?ua=1

2. Olu O, Babaniyi O, Songolo P, et al. Cholera epidemiology in Zambia from 2000 to 2010: implications for improving cholera prevention and control strategies in the country. East Afr Med J 2013;90(10):324-31.

3. Poncin M, Zulu G, Voute C, et al. Implementation research: reactive mass vaccination with single-dose oral cholera vaccine, Zambia. Bull World Health Organ 2017; In press.

4. Chun J, Huq A, Colwell RR. Analysis of 16S-23S rRNA intergenic spacer regions of Vibrio cholerae and Vibrio mimicus. Appl Environ Microbiol 1999;65(5):2202-8.

5. Hoshino K, Yamasaki S, Mukhopadhyay AK, et al. Development and evaluation of a multiplex PCR assay for rapid detection of toxigenic Vibrio cholerae O1 and O139. FEMS Immunol Med Microbiol 1998;20(3):201-7.

6. Lee KJ, Carlin JB. Multiple imputation for missing data: fully conditional specification versus multivariate normal imputation. Am J Epidemiol 2010;171(5):624-32.

7. White IR, Royston P, Wood AM. Multiple imputation using chained equations: Issues and guidance for practice. Stat Med 2011;30(4):377-99. 
Delayed second dose of oral cholera vaccine administered before high-risk period for cholera transmission: Cholera control strategy in Lusaka, 2016.

PloS One. 2019;14(8):e0219040. 



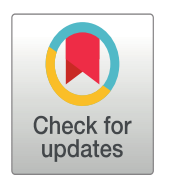

\section{G OPENACCESS}

Citation: Ferreras E, Matapo B, Chizema-Kawesha E, Chewe O, Mzyece H, Blake A, et al. (2019) Delayed second dose of oral cholera vaccine administered before high-risk period for cholera transmission: Cholera control strategy in Lusaka, 2016. PLOS ONE 14(8): e0219040. https://doi.org/ 10.1371/journal.pone.0219040

Editor: Holly Seale, University of New South Wales, AUSTRALIA

Received: February 21, 2019

Accepted: June 16, 2019

Published: August 30, 2019

Copyright: @ 2019 Ferreras et al. This is an open access article distributed under the terms of the Creative Commons Attribution License, which permits unrestricted use, distribution, and reproduction in any medium, provided the original author and source are credited.

Data Availability Statement: All relevant data are within the paper and its Supporting Information files.

Funding: This study was funded by Médecins Sans Frontières https://www.msf.org/ and the World Health Organization https://www.who.int/, who played a role in all aspects of this study, including the design, data collection, analysis, decision to publish and in the preparation of the manuscript.
RESEARCH ARTICLE

\section{Delayed second dose of oral cholera vaccine administered before high-risk period for cholera transmission: Cholera control strategy in Lusaka, 2016}

\author{
Eva Ferreras ${ }^{1,20} *$, Belem Matapo ${ }^{10}$, Elizabeth Chizema-Kawesha ${ }^{3}$, Orbrie Chewe ${ }^{3,4}$, \\ Hannah Mzyece ${ }^{3,4}$, Alexandre Blake ${ }^{2}$, Loveness Moonde ${ }^{3}$, Gideon Zulu ${ }^{3}$, Marc Poncin ${ }^{5}$, \\ Nyambe Sinyange ${ }^{3,4}$, Nancy Kasese-Chanda ${ }^{3}$, Caroline Phiri ${ }^{3}$, Kennedy Malama ${ }^{3}$, \\ Victor Mukonka ${ }^{4}$, Sandra Cohuet ${ }^{2}$, Florent Uzzeni ${ }^{5}$, Iza Ciglenecki ${ }^{5}$, M. Carolina Danovaro- \\ Holliday ${ }^{6}$, Francisco J. Luquero ${ }^{2,7 \ddagger}$, Lorenzo Pezzoli ${ }^{6 \neq}$
}

1 World Health Organization, Lusaka, Zambia, 2 Epicentre, Paris, France, 3 Ministry of Health, Lusaka, Zambia, 4 Zambia National Public Health Institute, Lusaka, Zambia, 5 Médecins Sans Frontières, Geneva, Switzerland, 6 World Health Organization, Geneva, Switzerland, 7 Department of International Health, Johns Hopkins Bloomberg School of Public Health, Baltimore, Maryland, United States of America

- These authors contributed equally to this work.

$\ddagger$ These authors also contributed equally to this work.

* ferreras_eva@yahoo.fr

\section{Abstract}

\section{Background}

In April 2016, an emergency vaccination campaign using one dose of Oral Cholera Vaccine (OCV) was organized in response to a cholera outbreak that started in Lusaka in February 2016. In December 2016, a second round of vaccination was conducted, with the objective of increasing the duration of protection, before the high-risk period for cholera transmission. We assessed vaccination coverage for the first and second rounds of the OCV campaign.

\section{Methods}

Vaccination coverage was estimated after each round from a sample selected from targeted-areas for vaccination using a cross-sectional survey in to establish the vaccination status of the individuals recruited. The study population included all individuals older than 12 months residing in the areas targeted for vaccination. We interviewed 505 randomly selected individuals after the first round and 442 after the second round. Vaccination status was ascertained either by vaccination card or verbal reporting. Households were selected using spatial random sampling.

\section{Results}

The vaccination coverage with two doses was $58.1 \%(25 / 43 ; 95 \% \mathrm{Cl}$ : $42.1-72.9)$ in children $1-5$ years old, $59.5 \%(69 / 116 ; 95 \% \mathrm{Cl}$ : $49.9-68.5)$ in children $5-15$ years old and $19.9 \%(56 /$ $281 ; 95 \% \mathrm{Cl}$ : $15.4-25.1$ ) in adults above 15 years old. The overall dropout rate was $10.9 \%$ 
Competing interests: The authors have declared that no competing interests exist.
(95\%Cl: 8.1-14.1). Overall, 69.9\% $(n=309 / 442 ; 95 \% \mathrm{Cl}: 65.4-74.1)$ reported to have received at least one OCV dose.

\section{Conclusions}

The areas at highest risk of suffering cholera outbreaks were targeted for vaccination obtaining relatively high vaccine coverage after each round. However, the long delay between doses in areas subject to considerable population movement resulted in many individuals receiving only one OCV dose. Additional vaccination campaigns may be required to sustain protection over time in case of persistence of risk. Further evidence is needed to establish a maximum optimal interval time of a delayed second dose and variations in different settings.

\section{Introduction}

Cholera remains a significant public health problem in many parts of the world. In 2016, 38 countries reported a total of 132121 cases including 2420 deaths, resulting in an overall case fatality rate (CFR) of $1.8 \%$ [1]. In Zambia, cholera has caused regular widespread epidemics during the rainy season since 1990. Annual epidemics have been reported between 2003 and 2010, mainly affecting the capital, Lusaka. No epidemics had been notified since 2011 [2,3], but a new cholera outbreak started in Lusaka in February 2016.

In April 2016, an emergency reactive vaccination campaign using Oral Cholera Vaccine (OCV) was organized in response to the epidemic [4,5] (Fig 1). In order to halt transmission within Lusaka, and to limit the probability of spread within the country, Zambia's Ministry of Health, Médecins Sans Frontières and the World Health Organization (WHO) decided to use a single dose of $\mathrm{OCV}$, based on recent data suggesting that one dose can provide similar short-

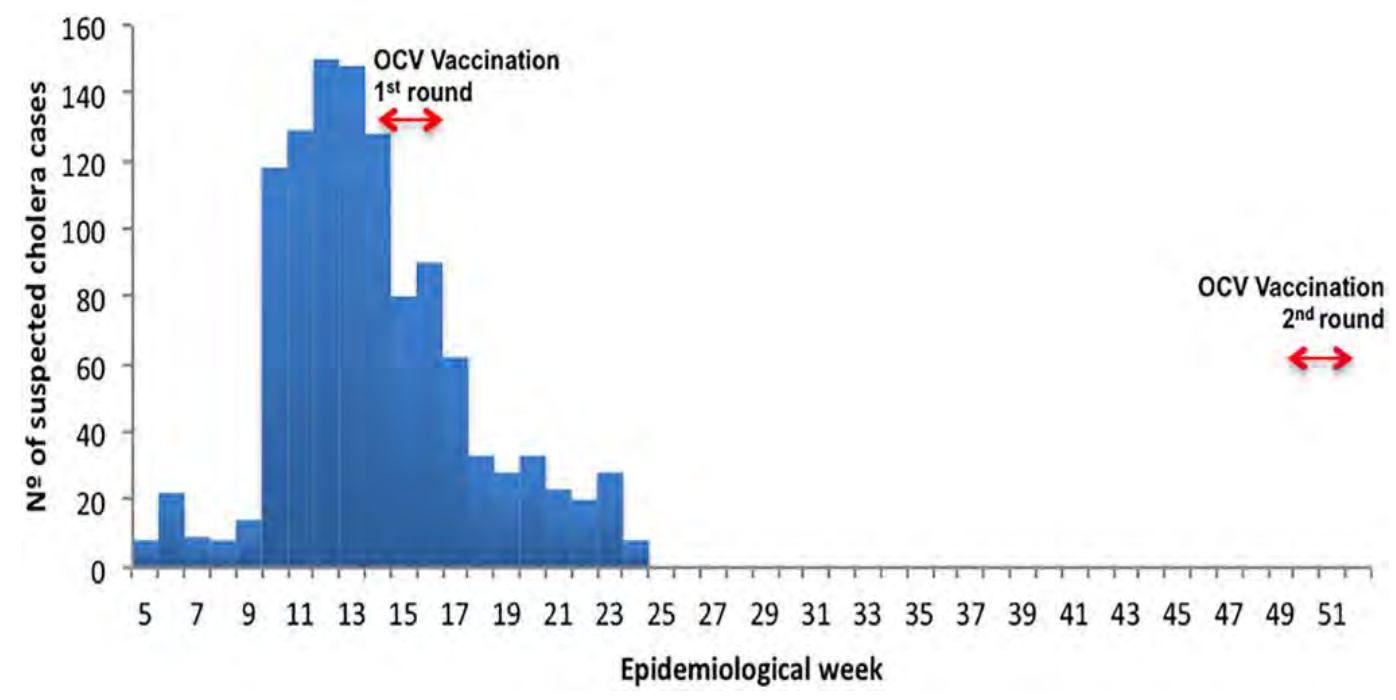

Fig 1. Cholera epidemic curve, Lusaka, Zambia, 2016. 


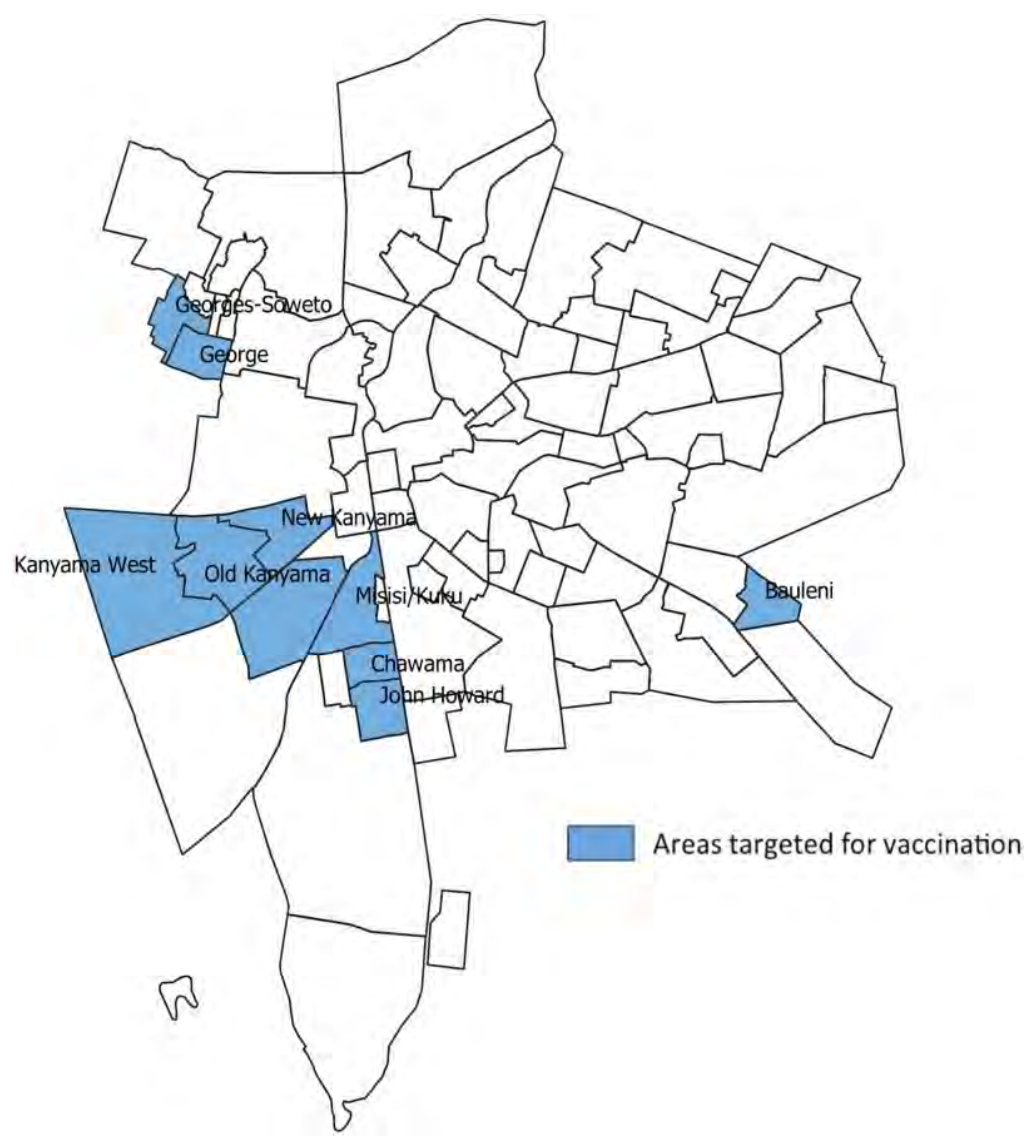

Fig 2. Selected areas for vaccination, Zambia, 2016

https://doi.org/10.1371/journal.pone.0219040.g002

term protection (estimated to be at least 6 months) compared to two doses [6-9], since there were not enough vaccines in the global stockpile to provide two doses, two weeks apart, to the population living in areas at high risk of transmission [6,8-11].

The aim of this campaign was to vaccinate the population living in areas within Lusaka at high risk of cholera to halt transmission within the city and to limit the probability of spread within the country [12].

The first OCV vaccination campaign (referred to, in this paper, as "first round") was conducted during from 9 to 23 April 2016 [5]. Four target locations were initially selected within Lusaka district, based on either cholera attack rates or as areas historically known to be prone to cholera: 1) Bauleni, 2) Kanyama (including John Laing, New Kanyama, Old Kanyama and Kanyama West), 3) George (including George Soweto) and 4) Chawama (including John Howard and Misisi-Kuku) (Fig 2).

A total of 578043 individuals aged 1 year or above were targeted and 424100 OCV doses were administered, resulting in $73.4 \%$ administrative coverage [5]. The outbreak was declared officially over on 15 June 2016 with a total of 1,139 suspected cholera cases and 10 deaths reported in health structures $(C F R=0.88)$ [5]. 
From 16 to 24 December 2016, the country conducted a second round of OCV vaccination (referred to as "second round") with the objective of increasing the duration of vaccine protection among individuals receiving the second dose and, in general, increasing the vaccinated population with any OCV dose before the rainy season (often associated with cholera). The target population was the same as for the first round. A total of 437143 doses were administered resulting in $80.4 \%$ administrative coverage [13].

We estimated vaccination coverage after each round and the dropout rate (individuals reporting being vaccinated in April in 2016 who did not receive the second dose in December) in order to assess the proportion of people who received two OCV doses and the proportion that remained partially vaccinated or unvaccinated before the start of the 2017 cholera season in Lusaka.

\section{Materials and methods}

\section{Study design}

After the first round, a sample was randomly selected from the areas considered at high risk for cholera to build a cohort within vaccinated areas and non-vaccinated areas with the main objective of estimating Vaccine Effectiveness (VE) of one OCV dose [14]. The sub-cohort selected from vaccinated areas was used to estimate the vaccination coverage. After the second round, a second independent cross-sectional survey was carried out to estimate the OCV vaccination coverage.

The study population included all individuals older than 12 months residing in Bauleni, Kanyama, Chawama and George during each vaccination round. Residents were defined as persons living (sleeping and eating) for, at least, the previous two weeks in these neighbourhoods.

For the sample size calculation, we considered the following assumptions: $50 \%$ of people would receive two doses, a confidence interval of $95 \%$ (equivalent to an alpha error of 5\%) and a precision of $5 \%$. There was no need to take into account a design effect since this was a simple random sample.

We planned to visit 442 households and to interview one person per household. The representative sample of the population was selected using spatial sampling [15] in both surveys. A random point was generated in the sampling area and was retained if it coincided with a household (+/- 10 meters error); the process was repeated until the sample size was reached. One individual was randomly selected in each household among all eligible individuals being part of the household at the time of the survey. The selection of the individual at the household was done with the help of tablet device-based software. If the selected person did not meet the eligibility criteria (older than 12 months on the first day of vaccination campaign and resided in the same household in Lusaka for at least the past two weeks), the next household on the right was selected. If the selected person refused to participate, a new random point was generated.

\section{Data collection}

Three teams comprised of 3 surveyors and 1 team leader conducted the data collection. Surveyors and team leaders were trained on the study procedures, GPS-use, sampling strategy, interviewing procedures and data collection. The questionnaire was piloted at the end of the training.

Teams conducted face-to-face interviews after obtaining written consent. A second visit was organized later in the day or on the second day if the selected participant was absent. If 
during the second visit the household members could not be found or refused to participate, that household was skipped. Household visits, absent households and refusals were recorded.

A standardized questionnaire was used to collect information about demographic data (age, sex and household size), having received a card and card availability at the time of the survey, vaccination status (self-reported and card-confirmed), reasons for non-vaccination (open question) and acceptability data (adverse events, taste and beliefs about the vaccine) using Kobo Toolbox software 1.4.8 (Cambridge, MA, USA).

\section{Data analysis}

OCV coverage of two doses (full course), with at least one dose, and single dose coverage (after the first and the second round), were calculated by dividing the number of individuals reporting being vaccinated by the survey population and expressed as a percentage. Vaccination coverage included both card-confirmed and verbally reported vaccination status. We estimated 95\% confidence intervals (Fisher's exact test).

In addition, we calculated the dropout rate between rounds as follows: Dropout rate $(\%)=$ (OCV first dose-OCV second dose/ OCV first dose) x 100.

Data analysis was carried out using R statistical software, version 3.2.3, taking into account the sampling scheme.

\section{Ethical considerations}

The Ethical Review Boards of the University of Zambia and the Johns Hopkins Bloomberg School of Public Health (USA) approved the study protocol for the cohort recruitment.

The study protocol for the coverage survey was approved by the ERES-Converge-Ethical Review Committee in Zambia and the clearance to conduct the survey was granted by the National Health Research Agency.

Privacy, confidentiality and rights of participants were guaranteed during and after the study. A signed informed consent was sought from each individual, or in case of a minor, from their guardian. From the 947 participants in both rounds, 417 were minors. All data was entered and analysed anonymously.

\section{Results}

\section{Sample description}

From 17 April 2016 to 25 May 2016, following the first round of the OCV campaign, 505 individuals were recruited from vaccinated areas in Lusaka as part of the survey cohort. The median age was 20 years old (interquartile rage (IQR): 9-30 years). The participation of males (59\%) was more than that of women. The average household size was 5 (standard deviation: 2.3). The participation rate was: $100 \%$

From 3 to 17 March 2017, 478 households were visited for the vaccination coverage survey conducted after the second round,. Occupants from 11 households could not be found after two visits; 467 individuals were screened for participation in the survey. Among these individuals, 18 refused to participate and 7 were ineligible.

Finally, 442 were included in the analysis. The average household size was 4 (standard deviation: 2.4 ). The median age was 21 years old (IQR: $10-34$ years). The male/female ratio was 0.64 . 


\section{First vaccination round: April 2016}

Overall, in the survey conducted in May 2016, 68.5\% (346/505; 95\%CI: 64.3-72.5) of the target population reported having received one OCV dose during the first round in April 2016 (Table 1). The percentage of individuals having the vaccination card among those reporting being vaccinated in the first round was $50.9 \%$.

During the coverage survey following the second OCV dose, only $44.8 \%$ (198/442; $95 \% \mathrm{CI}$ : 40.0-49.6) of people living in the targeted areas reported having been vaccinated in April 2016. When we stratified by age groups, we found that for 5 to 15 years the coverage was $68.1 \%$ ( 79 / 116; 95\%CI: 58.8-76.4) and 32.7\% (92/281; 95\%CI: 27.3-38.6) for adults. (Table 1).

\section{Second vaccination round: December 2016}

The study estimated that $59.0 \%$ (261/442; 95\%CI: 54.3-63.7) of the target population received one dose of vaccine during the second OCV round in December 2016 (Table 1). The percentage of individuals presenting the vaccination card among those reporting having been vaccinated was $24.0 \%(\mathrm{n}=83)$.

\section{Overall two dose and single dose vaccination coverage}

Coverage with two OCV doses was 33.9\% (150/442; 95\%CI: 29.5-38.6) and 36.0\% reported having received a single OCV dose (159/442; 95\%CI: 31.5-40.6). Hence, at the time of the 2017 vaccination coverage survey, $69.9 \%$ (309/442; 95\%CI: 65.4-74.1) reported to have received at least one OCV dose, in either of the two rounds, (Table 1). The dropout rate was $10.9 \%$ (95\%CI: 8.1-14.1).

\section{Stratified analysis by age, sex and township}

Table 1 shows the overall vaccination coverage with two OCV doses, with single OCV dose and the coverage achieved in the first and second vaccination rounds stratified by age group, sex and township.

Table 1. Vaccination coverage for two, one and at least one OCV dose, and for the first and the second round of the campaign; by age group, sex and township.

\begin{tabular}{|c|c|c|c|c|c|c|c|c|c|c|c|c|}
\hline & \multicolumn{2}{|r|}{2 doses VC } & \multicolumn{2}{|r|}{1 dose VC } & \multicolumn{2}{|c|}{ At least 1 dose VC } & \multicolumn{2}{|r|}{ 1st round VC } & \multicolumn{2}{|r|}{ 1st round $\mathrm{VC}^{*}$} & \multicolumn{2}{|c|}{ 2nd round VC } \\
\hline & $\mathbf{n}$ & $\%(95 \% \mathrm{CI})$ & $\mathbf{n}$ & $\%(95 \% \mathrm{CI})$ & $\mathbf{N}$ & $\%(95 \% \mathrm{CI})$ & $\mathbf{n}$ & $\%(95 \% \mathrm{CI})$ & $\mathbf{n}$ & $\%(95 \% \mathrm{CI})$ & $\mathbf{n}$ & $\%(95 \% \mathrm{CI})$ \\
\hline Overall VC & 150 & $33.9(29.5-38.6)$ & 159 & $36.0(31.5-40.6)$ & 309 & $69.9(65.4-74.1)$ & 346 & $68.5(64.3-72.5)$ & 198 & $44.8(40.0-49.6)$ & 261 & $59.0(54.3-63.7)$ \\
\hline 1 to 5 years & 25 & $58.1(42.1-72.9)$ & 13 & $30.2(17.2-46.1)$ & 38 & $88.4(74.9-96.1)$ & 51 & $85.0(73.4-92.9)$ & 27 & $62.8(46.7-77.0)$ & 36 & $83.7(69.3-93.2)$ \\
\hline 5 to 15 years & 69 & $59.5(49.9-68.5)$ & 38 & $32.7(24.3-42.1)$ & 107 & $92.2(85.8-96.4)$ & 116 & $81.1(73.7-87.2)$ & 79 & $68.1(58.8-76.4)$ & 97 & $83.6(75.6-89.8)$ \\
\hline $15+$ years & 56 & $19.9(15.4-25.1)$ & 108 & $38.4(32.7-44.4)$ & 164 & $58.4(52.4-64.2)$ & 179 & $59.3(53.5-64.9)$ & 92 & $32.7(27.3-38.6)$ & 128 & $45.5(39.6-51.6)$ \\
\hline Males & 54 & $31.4(24.5-38.9)$ & 52 & $30.2(23.5-37.7)$ & 106 & $61.6(53.9-68.9)$ & 117 & $62.2(54.9-69.2)$ & 66 & $38.4(31.1-46.1)$ & 94 & $54.6(46.9-62.2)$ \\
\hline Females & 96 & & 107 & $40.0(34.0-46.1)$ & 268 & & 229 & & 132 & & 167 & \\
\hline Bauleni & 6 & & 9 & & 15 & & 20 & & 7 & & 14 & $63.6(40.6-82.8)$ \\
\hline Chawama & 23 & $35.4(23.9-48.2)$ & 26 & $0(28-52.9)$ & 49 & $75.4(63.1-85.2)$ & 51 & $68.0(56.2-78.3)$ & 27 & $41.5(29.4-54.4)$ & 45 & $69.2(56.5-80.1)$ \\
\hline George & 24 & $38.1(26.1-51.2)$ & 23 & $36.5(24.7-49.6)$ & 47 & $74.6(62.1-84.7)$ & 62 & $87.3(77.3-94.0)$ & 36 & $57.1(44.09-69.5)$ & 35 & $42.5-68.1)$ \\
\hline George-Soweto & 6 & $31.6(12.6-56.5)$ & 9 & $47.4(24.4-71.1)$ & 15 & $78.9(54.4-93.9)$ & 15 & $71.4(47.8-88.7)$ & 8 & $42.1(20.2-66.5)$ & 13 & $68.4(43.4-87.4)$ \\
\hline John-Howard & 10 & $41.7(22.1-63.4)$ & 9 & $37.5(18.8-59.4)$ & 19 & $79.2(57.8-92.9)$ & 16 & $55.2(35.7-73.6)$ & 10 & $41.7(22.1-63.3)$ & 19 & $79.2(57.8-92.9)$ \\
\hline Jhon Laing & 14 & $30.4(17.7-45.7)$ & 20 & $43.5(28.9-58.9)$ & 34 & $73.9(58.9-85.7)$ & 27 & $50.0(36.1-63.9)$ & 19 & $41.3(26.9-56.8)$ & 29 & $63.0(47.5-76.8)$ \\
\hline Kanyama West & 13 & $27.6(15.6-42.6)$ & 15 & $31.9(19.1-47.1)$ & 28 & $59.6(44.3-73.6)$ & 29 & $56.9(42.2-70.7)$ & 18 & $38.3(24.5-53.6)$ & 23 & $48.9(34.1-.63 .9)$ \\
\hline Misisi-Kuku & 21 & $37.5(24.9-51.4)$ & 19 & $33.9(21.8-47.8)$ & 40 & $71.4(57.8-82.7)$ & 44 & $69.8(57.0-80.8)$ & 27 & $48.2(34.6-61.9)$ & 34 & $60.7(46.7-73.5)$ \\
\hline New Kanyama & 6 & $23.1(8.97-43.6)$ & 6 & $23.1(8.9-43.6)$ & 12 & $46.1(26.6-66.6)$ & 20 & $69.0(49.2-84.7)$ & 10 & $38.5(20.2-59.4)$ & 8 & $30.8(14.3-51.8)$ \\
\hline Old Kanyana & 27 & $37.5(26.48-49.7)$ & 23 & $31.9(21.4-43.9)$ & 50 & $69.4(57.45-79.8)$ & 62 & $71.3(60.6-80.5)$ & 36 & $50.0(37.9-62)$ & 41 & $56.9(44.7-68.6)$ \\
\hline
\end{tabular}

${ }^{*}$ This estimate represents the percentage of people living in the targeted areas during March 2017 survey who verbally reported having been vaccinated in April 2016.

https://doi.org/10.1371/journal.pone.0219040.t001 


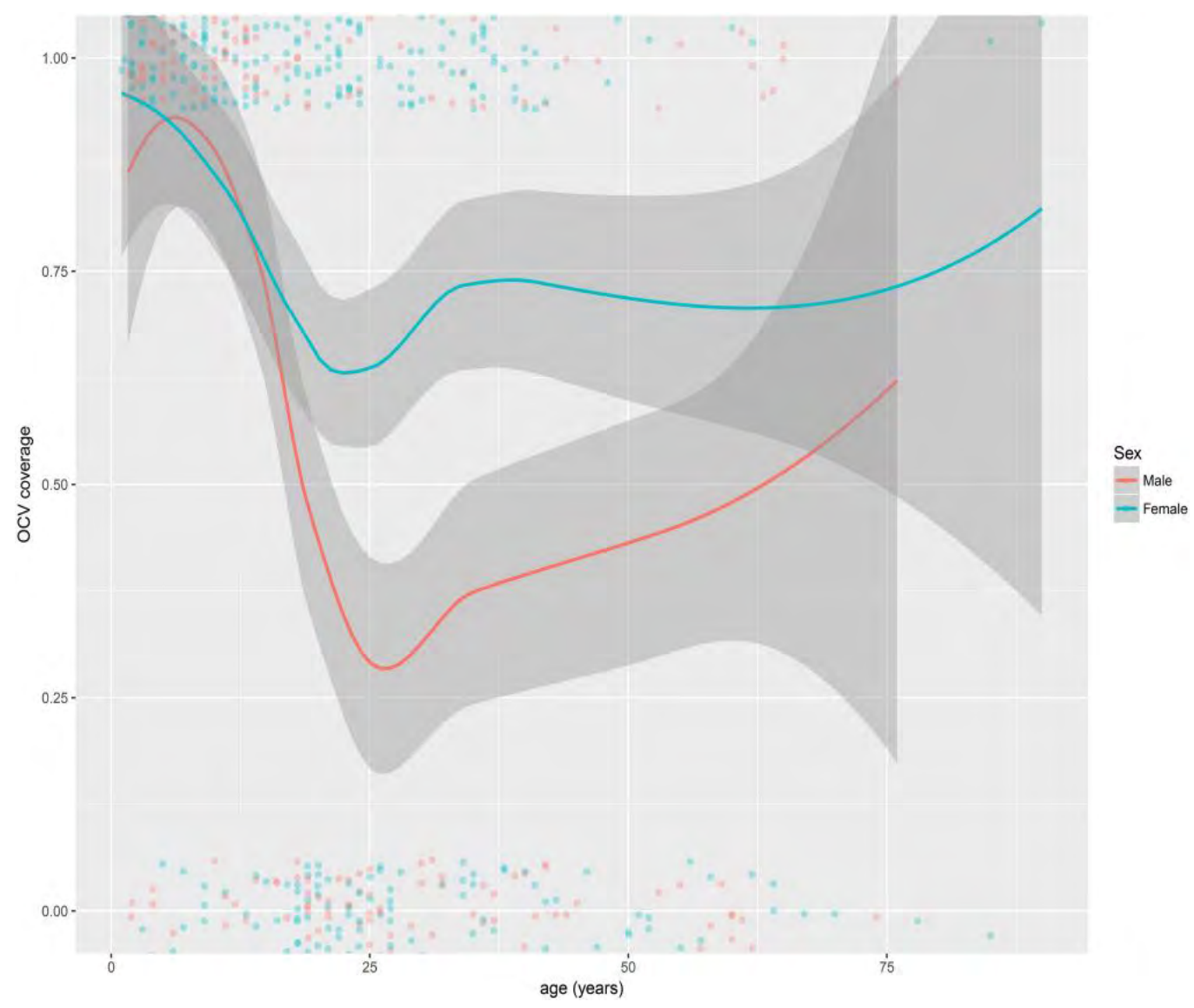

Fig 3. Vaccination coverage with at least one OCV dose by age and sex, Zambia, 2016.

https://doi.org/10.1371/journal.pone.0219040.g003

Vaccination coverage with two OCV doses was higher among children ((58.1\% (25/43; $95 \%$ CI: 42.1-72.9) for children 1-5 years old and 59.5\% (69/116; 95\%CI: 49.9-68.5) for 5-15 years old) than in adults (19.9\% (56/281; 95\%CI: 15.4-25.1) for adults above 15 years old) (Table 1$)$.

The vaccination coverage with at least one OCV dose was higher among women $75.7 \%$ (95\%CI: 70.2-80.7) than among men 61.6\% (95\%CI: 53.9-68.9) (Fig 3). This was especially true for the coverage with two doses among individuals between 25 and 50 years old (Fig 4).

The OCV coverage varied by township, with the highest vaccination coverage with at least one vaccine dose being observed in John-Howard (79.2\%, 95\%CI: 57.8-92.9) and the lowest in New Kanyama (46.1\%, 95\%CI: 26.6-66.6) (Table 1).

\section{Discussion}

Two rounds of vaccination using OCV were organized in 2016 in Lusaka with a similar number of doses distributed in both campaigns. The vaccination coverage achieved in the second round $(59.0 \%)$ in the targeted areas for vaccination was lower than the one obtained after the first vaccination round in April 2016 (68.6\%). Among the 36.0\% of individuals vaccinated with a single vaccine dose, the 30\% received this dose in April 2016 and the 70\% in December 2016. 


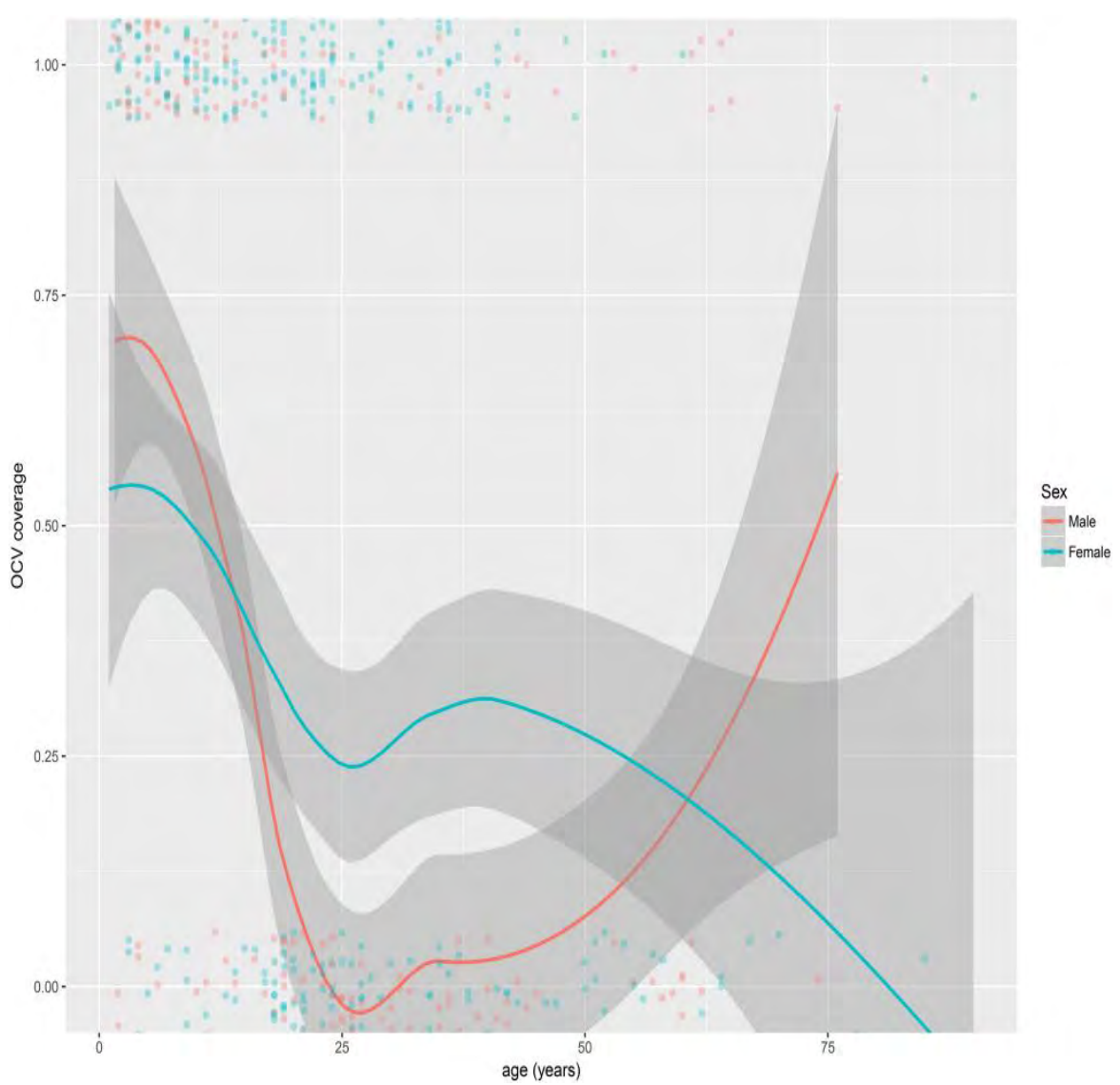

Fig 4. Vaccination coverage with two OCV doses by age and sex, Zambia, 2016.

https://doi.org/10.1371/journal.pone.0219040.g004

That suggest that only a fraction of the population vaccinated in April 2016 was still present in the vaccination areas in December, limiting the possibility to obtain high two OCV dose vaccination coverage.

The OCV vaccination coverage with a complete vaccine course was $33.9 \%$. We found large differences in two-dose vaccination coverage among children ( $58.1 \%$ in under 5 years old and $59.5 \%$ in 5 to 15 years old children) and adults (19.9\%), even if during the campaign this issue was detected and a catch-up activity was performed to narrow the gap in coverage between age groups [5]. Moreover, coverage in males was lower than in females, with this difference being higher for coverage with at least one OCV dose (61.6\% in males and $75.7 \%$ in females). Several publications have already described this issue in different contexts as in Guinea, Thailand and Bangladesh [16-18].

This was the first campaign using an eight-month delayed interval between doses. Most previous campaign coverage surveys focused on measuring full vaccination (two doses) coverage immediately after the implementation of the standard two doses campaign with a twoweek interval [19-21]. However, these evaluations have not addressed changing in OCV coverage over time. The survey implemented in Lusaka in March 2017 also allowed measuring the 
proportion of people in the target population who had been vaccinated in the April 2016 round. Despite possible information bias affecting this estimate, this percentage was relatively low, especially among the adult population, and raises an important question about the need to re-vaccinate populations to maintain a certain level of OCV coverage over time. In this study, coverage with two OCV doses (33.9\%) was lower than expected. The population mobility in these urban compounds is high and likely related to economical, seasonal, and work factors, especially in Kanyama townships. Moreover, during the 2016 OCV vaccination campaign, there were xenophobic riots in some of the targeted townships for vaccination [22].

An aspect that could be improved in future evaluations, considering the possible mobility of the population as a partial explanation of the findings, is to include additional details about when the individuals in the survey arrived to the target areas and from where, or how long they have lived in the area in order to better characterize the mobility patterns.

The delayed second OCV round allowed achieving vaccination coverage with at least one dose to $69.9 \%$ just before the start of the 2017 cholera season in Lusaka. Recent studies have shown that a single OCV dose provides a similar protection in the short term as a two-dose schedule $[6-8,14]$. Therefore, the delayed second OCV dose might have been an effective way to achieve a good level of protection before the cholera season in Lusaka and prevent or mitigate the possibility of a new outbreak in the vaccinated areas during 2017.

The desired sample size was achieved, which allowed having adequate precision for the overall estimates. However, the precision of the estimates by township, especially in Bauleni, was not optimal and stratified sampling by smaller geographical units should be considered in the future considering the differences observed by township.

The major limitation of this study was the high percentage of vaccinated individuals with missing vaccination cards despite the short interval between the vaccination campaign (April 2016 and December 2016) and the coverage surveys (May 2016 and March 2017). For the first vaccination round, this situation was likely affected by the poor-quality of the paper used for card printing. Vaccination cards ran out in the second round. Although it was recommended that people should bring their vaccination cards from the previous round, several people reported having forgotten or misplaced their cards. Plain pieces of paper were issued as proof of vaccination when the vaccination cards ran out. This could be an additional reason for the low card retention. The short delay between the campaign and the survey recruitment may have controlled the risk of having a large information bias in the vaccination status; however, it still highlights the difficulty to be certain about the vaccination coverage achieved. Also, possible recall or reporting bias may have been at play due to the 11-month delay between the first round and the March 2017 survey, which could have led to underestimating the coverage with two doses. It is likely that the people who did not take the OCV dose in December 2016 would have had more difficulties to recall having received the April OCV dose. This may explain the big discrepancies in the coverage of the first round among adults (and especially among males) between the 2016 and 2017 surveys (41.3\% of coverage among males in the 2016 survey and $14,7 \%$ in the 2017 survey).

\section{Conclusions}

The areas at highest risk of suffering cholera outbreaks were targeted for a vaccination campaign obtaining relatively high vaccine coverage (68.5\% in April and 59\% in December 2016). Overall, $69.9 \%$ of the people living in these areas, by March 2017, reported having received at least one dose of OCV. Considering the good short-term effectiveness of one vaccine dose, this might have been adequate to avoid a large outbreak in these high-risk areas during the 2017 main cholera season (January to June). On 6 October 2017 a new cholera outbreak 
was declared, having the index case in Chipata, an area not targeted during the 2016 OCV campaign.

However, the high population mobility suggests that coverage might drop over time, in particular among adults, where vaccination coverage levels are lowest (38.4\% with one dose, $58.4 \%$ with at least one dose and $19.9 \%$ with two doses). This issue should be evaluated and revaccination of these areas may be required to maintain good levels of protection. Furthermore, specific strategies may need to be developed to better reach the adult population, especially males, in order to increase OCV coverage among those aged 15 years and more.

We can conclude that, a strategy that includes a delayed second dose is pertinent in a scenario where it is not possible to vaccinate with two OCV doses in a normal two-week schedule, such as that of an epidemic situation where a prompt and reactive response is necessary and there is a limited stockpile of vaccines. This strategy allows to urgently control the outbreak with an increased number of doses (in terms of reducing morbidity, mortality and transmission) and, in addition, to increase the vaccine protection in the longer term. This example from Lusaka also suggests that for highly mobile populations, where the proportion of persons vaccinated following a mass vaccination campaigns might drop over time, a delay of eight months between OCV doses might be too long to ensure that the target population receives the recommended two doses. On the other hand, annual OCV campaigns before the cholera season might increase the number of individuals covered with at least one OCV dose and, consequently, might be also an effective strategy to reduce the risk of outbreaks in places at high risk of cholera transmission.

\section{Supporting information}

S1 Dataset.

S2 Dataset.

(XLSX)

S1 File.

(XLSX)

\section{Acknowledgments}

We would like to thank the field work team: Melody Kalombo, George Kapapi, Christabel Nkunika, Evans Mwango, Ellen Imasiku, Michael Mwamba, Gwenie Nseluke, Mercy Mutambo, Muziya Chika, Tangu Ngoma, Nicholas Zimba and Edward Chipalo for their intense and excellent work. And all people we interviewed for their patience.

\section{Author Contributions}

Conceptualization: Eva Ferreras, Belem Matapo, Elizabeth Chizema-Kawesha, Alexandre Blake, Caroline Phiri, Sandra Cohuet, Florent Uzzeni, Iza Ciglenecki, M. Carolina Danovaro-Holliday, Francisco J. Luquero, Lorenzo Pezzoli.

Data curation: Eva Ferreras, Alexandre Blake.

Formal analysis: Eva Ferreras, Alexandre Blake.

Funding acquisition: Belem Matapo, Florent Uzzeni, Iza Ciglenecki, Francisco J. Luquero, Lorenzo Pezzoli. 
Investigation: Eva Ferreras, Orbrie Chewe, Hannah Mzyece, Alexandre Blake, Loveness Moonde, Nyambe Sinyange.

Methodology: Eva Ferreras, Alexandre Blake, Francisco J. Luquero, Lorenzo Pezzoli.

Project administration: Eva Ferreras, Belem Matapo, Sandra Cohuet, Florent Uzzeni, Lorenzo Pezzoli.

Resources: Belem Matapo, Gideon Zulu, Marc Poncin, Kennedy Malama, Florent Uzzeni, Francisco J. Luquero.

Software: Eva Ferreras, Alexandre Blake.

Supervision: Eva Ferreras, Belem Matapo, Elizabeth Chizema-Kawesha, Gideon Zulu, Caroline Phiri, Kennedy Malama, Iza Ciglenecki, Francisco J. Luquero, Lorenzo Pezzoli.

Validation: Eva Ferreras, Alexandre Blake, Francisco J. Luquero.

Visualization: Eva Ferreras, Alexandre Blake, Francisco J. Luquero.

Writing - original draft: Eva Ferreras, Belem Matapo, Francisco J. Luquero.

Writing - review \& editing: Eva Ferreras, Belem Matapo, Elizabeth Chizema-Kawesha, Orbrie Chewe, Hannah Mzyece, Alexandre Blake, Loveness Moonde, Gideon Zulu, Marc Poncin, Nyambe Sinyange, Nancy Kasese-Chanda, Caroline Phiri, Kennedy Malama, Victor Mukonka, Sandra Cohuet, Florent Uzzeni, Iza Ciglenecki, M. Carolina Danovaro-Holliday, Francisco J. Luquero, Lorenzo Pezzoli.

\section{References}

1. World Health Organization. Cholera, 2016. Wkly Epidemiol Rec. 2017; 36(92):521-530.

2. ZambiaCountryProfile2011 [Internet] [cited 20 June 2019]. http://www. who.int/cholera/countries/ ZambiaCountryProfile2011.pdf?ua=1

3. Olu O, Babaniyi O, Songolo P, Matapo B, Chizema E, Kapin'a-Kanyanga M, et al. Cholera epidemiology in Zambia from 2000 to 2010: implications for improving cholera prevention and control strategies in the country. East Afr Med J. 2013; 90(10): 324-31. PMID: 26862642

4. Ministry of Health. 2010 Zambia cholera control guidelines (adapted from WHO). 1st Ed. Lusaka; 2011.

5. Poncin M, Zulu G, Voute C, Ferreras E, Muleya CM, Malama K, et al. Implementation research: the feasibility of a reduced-dose mass cholera vaccination campaign in response to an outbreak in Lusaka, Zambia. Bull World Health Organ. 2018; 96(2): 86-93.

6. Qadri F, Wierzba TF, Ali M, Chowdhury F, Khan Al, Saha A, et al. Efficacy of a Single-Dose, Inactivated Oral Cholera Vaccine in Bangladesh. N Engl J Med. 2016; 374(18): 1723-32. https://doi.org/10.1056/ NEJMoa1510330 PMID: 27144848

7. Luquero FJ, Grout L, Ciglenecki I, Sakoba K, Traore B. Heile M, et al. Use of Vibrio cholerae vaccine in an outbreak in Guinea. N Engl J Med. 2014; 370(22): 2111-20. https://doi.org/10.1056/ NEJMoa1312680 PMID: 24869721

8. Azman AS, Parker LA, Rumunu J, Tadesse F, Grandesso F, Deng LL, et al. Effectiveness of one dose of oral cholera vaccine in response to an outbreak: a case-cohort study. Lancet Glob Health. 2016; 4(11): e856-63. https://doi.org/10.1016/S2214-109X(16)30211-X PMID: 27765293

9. Bi Q, Ferreras E, Pezzoli L, Legros D, Ivers LC, Date K, et al. Protection against cholera from killed whole-cell oral cholera vaccines: a systematic review and meta-analysis. Lancet Infect Dis. 2017; 17(10): 1080-8. https://doi.org/10.1016/S1473-3099(17)30359-6 PMID: 28729167

10. Azman AS, Luquero FJ, Ciglenecki I, Grais RF, Sack DA, Lessler J. The Impact of a One-Dose versus Two-Dose Oral Cholera Vaccine Regimen in Outbreak Settings: A Modeling Study. PLoS Med. 2015; 12(8): e1001867. https://doi.org/10.1371/journal.pmed.1001867 PMID: 26305226

11. Parker LA, Rumunu J, Jamet $C$, Kenyi $Y$, Lino RL, Wamala JF, et al. Neighborhood-targeted and casetriggered use of a single dose of oral cholera vaccine in an urban setting: Feasibility and vaccine coverage. PLoS NegI Trop Dis. 2017; 11(6): e005652. https://doi.org/10.1371/journal.pntd.0005652 PMID: 28594891 
12. World Health Organization. Cholera vaccines: WHO position paper-August 2017 [Internet] [cited 20 June 2019]. http://apps. who. int/iris/bitstream/10665/258763/1/WER9234.pdf?ua=1

13. Lusaka district, Zambia. Oral cholera vaccination second round 2016: technical report. Available upon request.

14. Ferreras E, Chizema-Kawesha E, Blake A, Chewe O, Mwaba J, Zulu G, et al. Single-Dose Cholera Vaccine in Response to an Outbreak in Zambia. N Engl J Med. 2018; 378(6): 577-9. https://doi.org/10. 1056/NEJMc1711583 PMID: 29414267

15. Pearson AL, Rzotkiewicz A, Zwickle A. Using remote, spatial techniques to select a random household sample in a dispersed, semi-nomadic pastoral community: utility for a longitudinal health and demographic surveillance system. Int J Health Geogr. 2015; 14: 33. https://doi.org/10.1186/s12942-0150026-4 PMID: 26572873

16. Luquero FJ, Grout L, Ciglenecki I, Sakoba K, Traore B, Heile M, et al. First outbreak response using an oral cholera vaccine in Africa: vaccine coverage, acceptability and surveillance of adverse events, Guinea, 2012. PLoS NegI Trop Dis. 2013; 7(10): e2465. https://doi.org/10.1371/journal.pntd.0002465 PMID: 24147164

17. Phares $\mathrm{CR}$, Date $\mathrm{K}$, Travers $\mathrm{P}$, Déglise $\mathrm{C}$, Wongjindanon $\mathrm{N}$, Ortega $\mathrm{L}$, et al. Mass vaccination with a two-dose oral cholera vaccine in a long-standing refugee camp, Thailand. Vaccine. 2016; 34(1): 12833. https://doi.org/10.1016/j.vaccine.2015.10.112 PMID: 26549363

18. Khan IA, Saha A, Chowdhury F, Khan Al, Uddin MJ, Begum YA, et al. Coverage and cost of a large oral cholera vaccination program in a high-risk cholera endemic urban population in Dhaka, Bangladesh. Vaccine. 2013; 31(51): 6058-64. https://doi.org/10.1016/j.vaccine.2013.10.021 PMID: 24161413

19. Lam E, Al-Tamimi W, Russell SP, Butt MOI, Blanton C, Musani AS, et al. Oral Cholera Vaccine Coverage during an Outbreak and Humanitarian Crisis, Iraq, 2015. Emerg Infect Dis. 2017; 23(1): 38-45. https://doi.org/10.3201/eid2301.160881 PMID: 27983502

20. Uddin MJ, Wahed T, Saha NC, Kaukab SST, Khan IA, Khan Al, et al. Coverage and acceptability of cholera vaccine among high-risk population of urban Dhaka, Bangladesh. Vaccine. 2014; 32(43):56905. https://doi.org/10.1016/j.vaccine.2014.08.021 PMID: 25149429

21. Tohme RA, François J, Wannemuehler K, lyengar $P$, Dismer A, Adrien $P$, et al. Oral Cholera Vaccine Coverage, Barriers to Vaccination, and Adverse Events following Vaccination, Haiti, 20131. Emerg Infect Dis. 2015; 21(6): 984-91. https://doi.org/10.3201/eid2106.141797 PMID: 25988350

22. British Broadcasting Corporation (BBC). Zambia xenophobic riots: two burned alive in Lusaka. 2016 [cited 20 June 2019] http://www.bbc.com/news/world-africa-36092917 
The feasibility of a reduced-dose mass cholera vaccination campaign in response to an outbreak in Lusaka, Zambia.

Bulletin World Health Organization. 2018 Feb;96(2):86-93. 



\section{Research}

\section{Implementation research: reactive mass vaccination with single-dose oral cholera vaccine, Zambia}

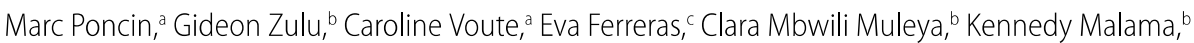
Lorenzo Pezzoli, ${ }^{d}$ Jacob Mufunda, ${ }^{e}$ Hugues Robert, ${ }^{\mathrm{a}}$ Florent Uzzeni, ${ }^{a}$ Francisco J Luquero, ${ }^{,}$Elizabeth Chizemab \& Iza Cigleneckia

Objective To describe the implementation and feasibility of an innovative mass vaccination strategy - based on single-dose oral cholera vaccine - to curb a cholera epidemic in a large urban setting.

Method In April 2016, in the early stages of a cholera outbreak in Lusaka, Zambia, the health ministry collaborated with Médecins Sans Frontières and the World Health Organization in organizing a mass vaccination campaign, based on single-dose oral cholera vaccine. Over a period of 17 days, partners mobilized 1700 health ministry staff and community volunteers for community sensitization, social mobilization and vaccination activities in 10 townships. On each day, doses of vaccine were delivered to vaccination sites and administrative coverage was estimated.

Findings Overall, vaccination teams administered 424100 doses of vaccine to an estimated target population of 578043 , resulting in an estimated administrative coverage of $73.4 \%$. After the campaign, few cholera cases were reported and there was no evidence of the disease spreading within the vaccinated areas. The total cost of the campaign - 2.31 United States dollars (US\$) per dose - included the relatively low cost of local delivery - US\$0.41 per dose.

Conclusion We found that an early and large-scale targeted reactive campaign using a single-dose oral vaccine, organized in response to a cholera epidemic within a large city, to be feasible and appeared effective. While cholera vaccines remain in short supply, the maximization of the number of vaccines in response to a cholera epidemic, by the use of just one dose per member of an at-risk community, should be considered.

Abstracts in عربي, 中文, Français, Русский and Español at the end of each article.

\section{Introduction}

The World Health Organization (WHO) has estimated that there are 1.3-4 million cholera cases and 21000-143000 cholera-related deaths each year. ${ }^{1}$ Cholera is a poverty-related disease and large-scale cholera epidemics continue to occur in low-income countries. In 2015, for example, an outbreak that involved approximately 40000 people affected parts of the Democratic Republic of Congo, Kenya and the United Republic of Tanzania. ${ }^{2}$ The prevention and control of epidemics are usually based on a multidisciplinary integrated approach that may include community sensitization, intensified epidemiological surveillance, improved access to clean water, hygiene and sanitation and the treatment of confirmed and suspected cases. Recent large-scale cholera outbreaks have shown the limitations of standard response measures and the need for improved strategies. ${ }^{2}$

The first documented campaign using oral cholera vaccine in a humanitarian context was carried out in 1997, in Uganda. ${ }^{3}$ Since then, similar preventive vaccinations have been organized in areas considered at risk of a cholera outbreak. $^{4-6}$ In recent years, increased use of oral cholera vaccine in different settings and mostly in a preventive manner has provided evidence of the feasibility and effectiveness of vaccination campaigns against cholera. ${ }^{7,8} \mathrm{~A}$ turning point in the implementation of cholera vaccination campaigns was
WHO's prequalification of the Shanchol oral cholera vaccine in 2011. ${ }^{9}$ In 2013, under the supervision of the International Coordination Group on Vaccine Provision, a global stockpile of oral cholera vaccine was created to strengthen the capacity for action against cholera in emergency settings. ${ }^{9,10}$

Timely reactive vaccinations - i.e. vaccinations in response to an existing epidemic - for cholera outbreaks are challenging, because it can take considerable time to identify and report a cholera epidemic and it is hard to predict outbreaks. Other possible challenges are inadequate financial and human resources and inadequate number of doses to target everyone at risk of cholera, especially for a multi-dose campaign. ${ }^{11}$ While the licensed protocol requires two doses of oral cholera vaccine to be given two weeks apart, the feasibility of such a regimen has been, and remains, limited by the availability of suitable vaccines doses. Given a global shortage of such vaccines, a single-dose strategy, which, given a fixed number of doses, could cover twice as many people as a two-dose regimen, should be considered. ${ }^{12}$ This strategy was first used under field conditions in 2015, in Juba, the conflict-ravaged capital of South Sudan, when more than 160000 people were vaccinated in response to a cholera outbreak. ${ }^{11}$ In a short-term observational study, the effectiveness of a single dose of vaccine in this campaign in Juba was estimated to be $87.3 \%$ ( $95 \%$ confidence interval, CI: 70.2-100.0). ${ }^{13}$ In 2014, a clinical trial in Bangladesh indicated that a single dose of oral cholera vaccine would give

a Médecins sans Frontières, 78, rue de Lausanne, Case Postale 1016, 1211 Geneva, Switzerland.

${ }^{b}$ Republic of Zambia Ministry of Health, Lusaka, Zambia.

Epicentre, Paris, France

'World Health Organization, Geneva, Switzerland

' World Health Organization, Lusaka, Zambia.

Correspondence to Marc Poncin (email: marc.poncin@geneva.msf.org).

(Submitted: 2 December 2016 - Revised version received: 30 September 2017 - Accepted: 2 October 2017 - Published online: 19 October 2017) 
$40 \%$ (95\% CI: $11-60)$ and $63 \%$ (95\% CI: 24-82) protection against all and severe episodes of cholera, respectively. ${ }^{14}$

Cholera is a public-health problem in many areas of Zambia, but is a particular problem in the capital, Lusaka. ${ }^{15}$ Although there were annual cholera epidemics in Zambia between 2003 and 2011, no confirmed cases of the disease were reported in the country in 2012-2015. When, therefore, a few people with the disease were detected in Lusaka in February 2016, general levels of immunity to cholera were assumed to be relatively low in Zambia. At the time, there was concern that there was considerable risk of an imminent major outbreak. The Lusaka District Health Office quickly organized a response according to the national guidelines on cholera control. ${ }^{16}$ In addition, the Zambian Ministry of Health, with support from Médecins Sans Frontières and WHO, implemented a reactive vaccination campaign with the aim of stopping transmission of Vibrio cholerae in Lusaka. In 2016, almost 600000 people were living in the nine townships of Lusaka that were considered at greatest risk, because they had been the foci of cholera outbreaks in the previous two decades. Given the large target population and the global shortage of appropriate vaccine doses, it was decided to use a single-dose vaccination campaign, rather than a two-dose strategy, and so allow the largest number of vulnerable people to be vaccinated with the doses that were available.

Here we describe the context of the interventions and the decision-making process and we evaluate the feasibility of conducting such a large-scale reactive campaign of cholera vaccination in high-risk and densely-populated urban areas.

\section{Methods}

Setting

Lusaka is a fast-growing city with a population of over 2 million people. Between 2003 and 2011, there were annual cholera epidemics, 26000 cholera cases and 860 cholera-related deaths recorded in the city. ${ }^{15,17}$ Over this period, Médecins Sans Frontières helped the health ministry to control the cholera outbreaks in the city and record the numbers of people with cholera per township, the seasonal pattern of cholera and assess water and sanitation quality

\section{Fig. 1. Weekly numbers of confirmed and/or suspected cases of cholera reported in Lusaka, Zambia, 2016}

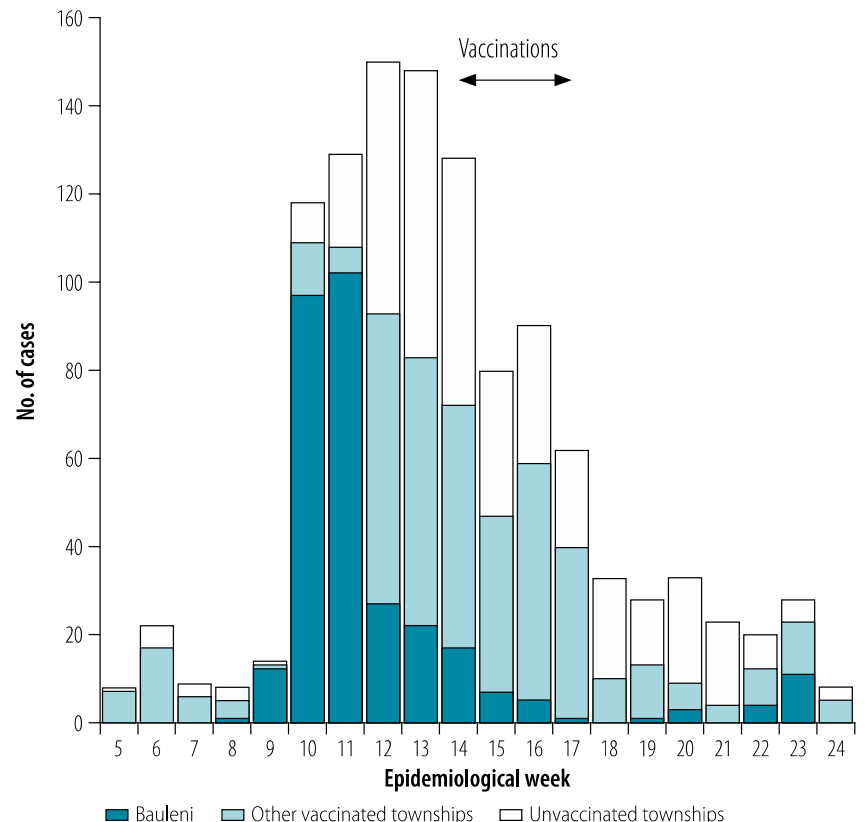

Notes: The graph shows epidemiological weeks. Single doses of oral cholera vaccine were administered between week 14 and week 17. The case numbers for Bauleni township, the other nine townships that were targeted in a mass immunization campaign based on single doses of oral cholera vaccine and the city's other townships, in which there were no immunizations with oral cholera vaccine, are presented separately.

in each township. ${ }^{17}$ Most epidemics recorded in the city since 2003 began in December/January and finished, as the rainy season ended, around April/May. ${ }^{17}$ They started in one or more of nine townships that had particularly poor water supplies and drainage systems. ${ }^{17}$

On 4 February 2016 - i.e. in epidemiological week 5 of 2016 - a person with cholera was identified in Lusaka. This represented the first confirmed case in the city since 2011. Confirmed and/or suspected cases were identified over the next few days and a cholera outbreak was declared. Laboratory analysis showed that the agent causing this outbreak was $V$. cholerae $\mathrm{O} 1$ El Tor-Ogawa. The number of confirmed and/or suspected cases increased rapidly, from 14 in epidemiological week 9 to 118 in epidemiological week 10 (Fig. 1)

\section{Decision-making and vaccine} provision

In early March 2016, the health ministry, fearing an imminent major epidemic, requested the assistance of Médecins Sans Frontières in controlling the epi- demic. There were 277 confirmed and/ or suspected cholera cases reported on 18 March. Of these cases, 57 were found positive in a rapid diagnostic test for cholera and 25 were confirmed by culture. As a result of these observations, the health ministry, Médecins Sans Frontières and WHO agreed to add vaccination to the standard cholera-control activities that had already been implemented. However, when this agreement was made, the global emergency stockpile of oral cholera vaccine, containing about 1.3 million doses, was far too small to allow Zambia and several other countries with urgent requirements for cholera vaccine to give everyone in at-risk populations two doses. We therefore decided to follow a single-dose vaccination strategy in Lusaka, to cover everyone who was older than one year and lived in a high-risk township, and to consider delivering a second dose later, when more vaccine doses became available. On March 24, the health ministry sent a request to the International Coordination Group, to access 598131 
doses from the emergency stockpile ${ }^{18}$ and they received a positive response five days later. The allocated vaccine was Shanchol (Shantha Biotechnics, Hyderabad, India) and the vaccine doses arrived in Zambia, in two shipments, on 7 and 8 April. Although Shanchol was not registered in Zambia, the health ministry approved its emergency use and facilitated the importation process.

\section{Target population}

The target population included all individuals older than one year who lived in one of the 10 townships of Lusaka that, in March 2016, were considered highrisk for cholera. Nine townships had the highest attack rates in the epidemics in 2003-2011 and one township had a high incidence of suspected cholera when the vaccine request was sent. To estimate the population of these townships, we combined population projections from the 2010 national census ${ }^{19}$ with other relevant population data (Lusaka City Council, unpublished data, 2016)

\section{Vaccination strategy}

Vaccination teams implemented a twophase strategy designed to cover the entire target population within a short period. The first phase involved the setting up of static vaccination sites, which were easy to organize and control, in health facilities or churches or schools. Each static site was covering a circular area, centred on the site, with a maximum radius of $500 \mathrm{~m}$ (Fig. 2). Each such site was scheduled to open from 07:00 to $18: 00$ on each of two to six days, the exact period depending on the turn-out of the target population. We set a vaccination target of each static site to 5500 doses per day, to match the financial and logistical resources that were available.

The second phase comprised three-day catch-up campaign in which mobile vaccination teams operated, on main roads or in markets or other socially active places, to vaccinate targeted individuals who had failed to attend the static sites.

\section{Vaccination teams}

Each vaccination team was composed of 23 volunteers and a qualified nurse from the health ministry who acted as team leader. Before the campaign, we organized a half-day training session in each high-risk township. This included a practical exercise in organizing a vaccination site. The team composition was such that, at each vaccination site, two vaccination lines, each run by two vaccinators, two people preparing vials, four recorders filling in cards and one person summarizing the records on a tally sheet, could be formed. Other team members were responsible for crowd control. In an attempt to facilitate the acceptance of the campaign, we selected the team members for each targeted township from the local population. Overall, 989 individuals created 53 teams, 42 at static sites and 11 running the mobile sites. At the height of the activity there were 17 sites working simultaneously.

\section{Fig. 2. Estimated administrative coverages in the 10 townships of Lusaka targeted in a mass immunization campaign against cholera,} Zambia, 2016

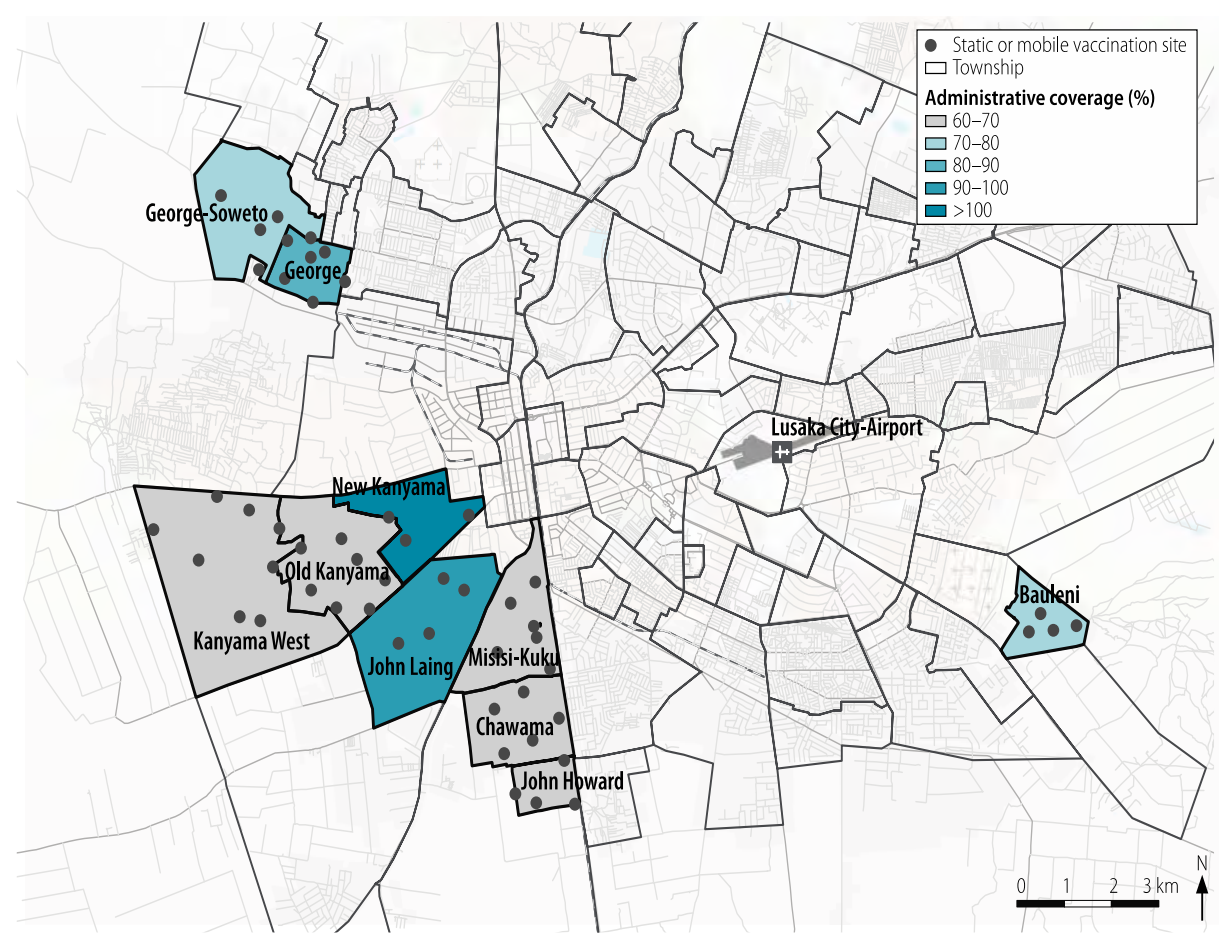

Note: Data are shown only for the areas targeted in a mass immunization campaign based on single doses of oral cholera vaccine, i.e. Bauleni township in the east of the city and nine other townships in the west 


\section{Social mobilization}

In each targeted township, qualified environmental health technicians from the health ministry organized three days of community sensitization and mobilization before the vaccinations began and then continued similar activities for the duration of the campaign. A flyer explaining the characteristics of the vaccine and the dates and locations of the vaccination sites was developed locally and handed out. Vehicles with sound systems were driven around the targeted townships to advertise the vaccinations. Awareness-raisers worked near the vaccination sites. There were another 745 individuals, again a mix of health ministry staff and community volunteers, involved in the social mobilization.

\section{Cold-chain management}

The Universal Child Immunization's Secretariat Office in Lusaka stored the vaccines in a cold room. We distributed the vaccines to vaccination sites, with icepacks, as 1500-dose boxes in their original packaging. The vaccines were used at ambient temperature on the vaccination day. The vaccinators checked the vaccine vial monitor before administering each dose

\section{Data collection and analysis}

Recorders categorized the age of each vaccinee as one to four years, five to 14 years or adult, i.e. at least 15 years, on a tally sheet, but ignored sex. On a daily basis, the recorders compiled the sheets to allow the daily evaluation of administrative coverages to be estimated each day. The estimated coverages were then used to plot a performance map for each targeted township. By rapidly sharing such maps among partners, it was possible to make quick compensations for poor coverage in particular areas, e.g. increasing the duration of the vaccination period at some sites and reinforcement of sensitization activities. We calculated vaccine wastage as the percentage of the number of doses leaving the cold room that, according to the tally sheets, were lost. We expressed cholera attack rates as the numbers of confirmed and/or suspected cases per 10000 people and we used Poisson regressions to compare such rates by age group and sex.

Although we assessed the shortterm effectiveness of the single-dose strategy and we implemented a coverage survey, the results of these activities will be reported separately.

\section{Ethics}

The vaccination campaign was conducted as part of the public health response to the cholera outbreak and was approved by the Zambian Ministry of Health.

\section{Results}

\section{Administrative coverage}

Between 9 and 25 April 2016, 424100 vaccine doses were administered to an estimated combined target population of 578043 , giving an estimated administrative coverage of $73.4 \%$. Estimated administrative coverage in the targeted townships varied between $61.9 \%$ and 105.8\% (Fig. 2)

Of the doses that vaccination teams administered, 371279 (87.5\%) were administered during the first phase - i.e. at the static sites - and the rest during the catch-up at mobile sites (Table 1) Although most of the doses used in the catch-up phase were used on adults, estimated administrative coverage remained generally higher in children than in adults (Table 1)

\section{Performance indicators}

At each of the static sites, the vaccination team administered cholera vaccine to a mean of 2256 (range: 306-5843) people per day, i.e. to about half of the target of 5500 . The corresponding number for the mobile sites was even lower: 1492 (range: 371-3757).

Vaccine wastage was less than $0.01 \%(459 / 424100)$. At the end of the campaign, 174031 doses remained in the cold room and were retained for possible use as second doses. There were no reports of doses being discarded because of invalid vaccine vial monitors.

\section{Costs}

Of the total cost of the vaccination campaign, which was 978614 United States

\begin{tabular}{|c|c|c|c|c|c|}
\hline \multirow{2}{*}{$\begin{array}{l}\text { Age } \\
\text { (years) }\end{array}$} & \multirow{2}{*}{$\begin{array}{c}\text { Target popula- } \\
\text { tion }^{\mathrm{a}}\end{array}$} & \multicolumn{3}{|c|}{ No. of vaccines (\% in age group) } & \multirow{2}{*}{$\begin{array}{c}\text { Administrative } \\
\text { coverage, } \%\end{array}$} \\
\hline & & First phase & Catch-up & Total & \\
\hline $1-5$ & 78189 & $75725(92.0)$ & $6609(8.0)$ & 82334 & 105.3 \\
\hline $5-15$ & 144652 & $163612(91.7)$ & $14839(8.3)$ & 178451 & 123.4 \\
\hline$>15$ & 355202 & $131942(80.8)$ & $31373(19.2)$ & 163315 & 46.0 \\
\hline All & 578043 & $371279(87.5)$ & $52821(12.5)$ & 424100 & 73.4 \\
\hline
\end{tabular}

dollars (US\$), US\$ 784831 (80.2\%) were used on vaccine procurement (Table 2). Local delivery cost was US $\$ 173677$, that is, a mean of just US $\$ 0.41$ per dose administered.

\section{Outbreak characteristics}

During the entire 2016 cholera outbreak in Lusaka, which ran between epidemiological week 5 and week 24, the health ministry reported 1139 confirmed and/ or suspected cholera cases (Fig. 1). Over the same period, the ministry recorded 20 cholera-related deaths, of which 10 occurred in community settings and 10 in health facilities. These 20 deaths represent $1.76 \%$ of the confirmed and/ or suspected cholera cases that were reported. The weekly incidence of cases peaked in epidemiological week 12, when 150 suspected cases were reported. In Lusaka, the overall attack rate was 4.89 per 10000 people. Attack rates were significantly higher among children younger than five years than among older individuals: 5.80 vs 4.71 per 10000 people (attack rate ratio: 1.23; 95\% CI: $1.06-1.42$ ). They were also significantly higher among males than among females: 5.20 vs 4.59 per 10000 people (attack rate ratio: 1.13 ; $95 \% \mathrm{CI}$ : 1.01-1.27).

Although we only implemented the vaccination campaign after the epidemic peaked in the Bauleni township, the campaign preceded the corresponding peaks in the other nine targeted townships (Fig. 1).

\section{Discussion}

In 10 apparently high-risk townships in Lusaka the vaccinators administered over 420000 doses of oral cholera vaccine, resulting in over $70 \%$ of the target population being vaccinated. Box 1 summarizes the major achievements and lessons learnt from the campaign. Such mass campaigns appear to be 
feasible within large urban settings. When, in 2016, the health ministry found itself faced with the threat of a major outbreak of cholera in Lusaka, it had no previous experience with vaccination campaigns against the disease. However, after careful review of the available literature, particularly the then-unpublished results of the singledose reactive campaign organized in South Sudan ${ }^{11,13}$ the health ministry took the decision to use a single-dose strategy. This was because insufficient vaccine doses were available to follow the more usual, two-dose regimen. The possibility of delivering a second dose at a later stage, once adequate doses of vaccine became available, was discussed during the planning phase. Using a combination of new stock and the doses leftover from the single-dose campaign, the health ministry administered second doses on 16-21 December 2016, i.e. before the 2016/2017 rainy season. Since then, single-dose campaigns based on oral cholera vaccine have taken place in Haiti and Mozambique. ${ }^{20}$ In April 2017, WHO's Strategic Advisory Group of Experts on immunization updated its recommendations on the use of oral cholera vaccine, stating that "a single dose strategy could be considered in areas experiencing cholera outbreaks. Considering the limited evidence about the duration of protection, additional doses might be needed to ensure longerterm protection." ${ }^{21}$

In reactive mass immunizations, a speedy response is needed if a major outbreak is to be prevented. In Lusaka in 2016, mass immunization began just 21 days after the decision to vaccinate was made and two months after the appearance of the first reported case. A key step was the rapid detection and declaration of the outbreak by the health ministry. Knowledge of the local cholera epidemiology and good collaboration between the ministry and its international partners allowed the choice of vaccination strategy, the preparation of the request for the vaccine doses from the global stockpile and the import of the released doses to proceed smoothly. This process also allowed vaccinations to begin as soon as the doses reached Lusaka. The coldchain logistics and vaccine distribution in Lusaka were simpler than those described in some other campaigns, ${ }^{7}$ thanks, in part, to the thermostability of the vaccine used.

\section{Table 2. Costs of the single-dose vaccination campaign against cholera, Lusaka, Zambia, 2016}

\begin{tabular}{lc}
\hline Characteristic & $\begin{array}{c}\text { Costs, US\$ (\% of } \\
\text { total) }\end{array}$ \\
\hline Vaccine purchase $^{\mathrm{a}}$ & $784831(80.2)$ \\
International shipment $^{\mathrm{a}}$ & $20106(2.0)$ \\
Staff incentives $^{b}$ & $65922(6.7)$ \\
Food, identification cards and other staff expenses $^{\mathrm{b}}$ & $10543(1.1)$ \\
Vaccination equipment and consumables $^{\text {Social mobilization materials and consumables }}$ & $25325(2.6)$ \\
Logistical costs of venue use and waste management $^{\text {Transport costs }}$ & $15252(1.6)$ \\
Total cost of the campaign $^{c}$ & $25081(2.6)$ \\
Total local delivery cost $^{c}$ & $31554(3.2)$ \\
\hline
\end{tabular}

US\$: United States dollars.

a The proportion of the total costs, for the 598131 imported doses, represented by the 424100 doses that were administered in the single-dose campaign.

Excluding the administrative costs for, and salaries of, any overseas personnel.

Excluding the costs of monitoring and evaluation.

\section{Box 1. Major achievements and lessons learnt from Lusaka vaccination campaign,} Zambia, 2016

\section{Outcome}

- In response to cholera outbreaks, large targeted reactive vaccination campaigns are feasible in large urban settings and can be deployed in a timely manner.

- Given a global shortage of cholera vaccines, a single-dose strategy allows a greater population to be vaccinated. In Lusaka, such a strategy allowed targeting of the entire population in the areas considered most at risk of Vibrio cholerae transmission.

- The per-dose cost of the Zambia campaign, implemented in response to an outbreak, was at least as low as that of campaigns implemented in non-outbreak settings and, since vaccination teams were underused, this could have been reduced.

\section{Implementation}

Factors that allowed a relatively quick decision-making process were: good understanding of the local cholera epidemiology, rapid confirmation and declaration of the outbreak by the health ministry and good collaboration between Médecins Sans Frontières, the health ministry and the World Health Organization in sending the vaccine request to the International Coordination Group early. In addition, the health ministry's anticipation of regulatory hurdles was a key factor in ensuring that the first use of oral cholera vaccine in Zambia began quickly.

- Use of static vaccination sites was probably a more efficient and cheaper strategy than house-to-house visits.

- Age stratification of the tally-sheet data allowed the catch-up activities to be focused mainly on adults, i.e. the age group that had relatively poor coverage in the first phase of the campaign. The recording on the tally sheets of the sex of each vaccine could have improved such focus on specific low-coverage groups. However, the coverages estimated in most urban campaigns of cholera vaccination indicate that specific approaches to improve coverage among adults, particularly men, should probably be implemented from the onset of any such campaign.

- In Lusaka and, probably, similar large urban settings, the cold chain for an oral cholera vaccine with good thermostability can be simply based on a single cold room for the time of the vaccination campaign.

Although some campaigns based on oral cholera vaccine have reached higher coverages, the overall administrative coverage achieved in Lusaka (73.4\%) was similar to that recorded in other urban campaigns. ${ }^{11,22,23}$ The accuracy of data on administrative coverage is often limited by the use of popula- tion estimates, especially when such estimates relate to a large city, such as Lusaka, that has a dynamic population and many informal settlements. During the 2016 vaccination campaign described here, there were xenophobic riots in some of the targeted townships ${ }^{24}$ and this unrest may have contributed 
to a lower coverage than initially expected. In Lusaka in 2016, as in several previous vaccination campaigns against cholera, ${ }^{6,11,23,25}$ administrative coverage was much poorer among adults than among children (Table 1). Although vaccinee sex was not recorded on the tally sheets, the vaccination teams reported that they vaccinated far fewer men than women at the static sites. While the catch-up campaign made it possible to narrow the gap in coverage between adults and children, coverage among adults, and particularly among men, remained relatively poor. In future similar campaigns, the tailoring of catch-up specifically to benefit women and, particularly, men needs to be carefully considered.

As the mean number of people vaccinated daily at each static site was considerably lower than the set target number, vaccination teams at the sites were generally underused. There was probably, therefore, scope to reduce the mean per-dose cost of the local implementation of the campaign. However, even with the underuse, the mean perdose cost of local delivery in Lusaka (US\$ 0.41 ) accounted for less than 20\% of the total per-dose costs and was lower than the corresponding values previously reported for the Shanchol vaccine. For example, it was lower than the corresponding values reported in India in 2011 (US\$0.49), ${ }^{26}$ Bangladesh in 2011 (US\$0.76), ${ }^{23}$ Guinea in 2012 (US\$ 0.89), ${ }^{27}$ and South Sudan in 2014 (US\$ 0.63). ${ }^{28}$ Between-study comparisons of per-dose costs have to be made with caution, because of the differences in the collection of cost data, estimation of per-dose costs and value of the United States dollar. ${ }^{29}$
Cholera vaccination campaign in Zambia

The number of people reported with cholera in Lusaka after the single-dose campaign remained limited and the outbreak did not spread within any of the 10 targeted townships even when access to safe drinking water and sanitation remained poor.

This large-scale single-dose campaign, run in a densely populated urban area, showed to be feasible and appeared effective. Given the continuing global shortage of cholera vaccines, the use of single doses of oral cholera vaccine will remain an important alternative vaccine-delivery strategy in future cholera epidemics.

\section{Acknowledgements}

We thank Timothy Fox, Jean-Guy Audéoud and Cecile Barrier.

Competing interests: None declared.

\section{摘要}

\section{实施研究: 赞比亚用单剂量口服霍乱疫苗进行反应性大规模疫苗接种}

目标旨在说明基于单剂量口服霍乱疫苗的创新型大规 模接种策略的实施和可行性, 以遏制大型城市环境中 的霍乱疫情。

方法 2016 年 4 月，在赞比亚卢萨卡霍乱爆发的早期阶 段, 卫生部门与无国界医生组织和世界卫生组织合作 组织了基于单剂量口服霍乱疫苗的大规模疫苗接种活 动。在 17 天的时间里，合作方共动员了 1700 名卫生 部工作人员和社区志愿者在 10 个乡镇开展社区宣传、 社会动员和疫苗接种活动。每天将疫苗剂量送到疫苗 接种处并估计接种覆盖率。

结果总体而言, 疫苗接种小组对估计的目标人

群 578043 人进行了 424100 剂疫苗接种, 估计接种覆 盖率为 $73.4 \%$ 。此项活动后, 报告的霍乱案例很少, 没有证据表明疫苗接种区域内有传染病。活动的总费 用一一每剂量 2.31 美元, 包括相对较低的本地交付成 本 (每剂量 0.41 美元)。

结论 我们发现, 使用单剂量口服疫苗的早期大规模针 对性反应性活动是为了应对大城市内的霍乱疫情而组 织起来的, 可行且有效。尽管霍乱疫苗仍然供不应求, 但每一名处于危险社区中的成员只需一个剂量, 应对 霍乱疫情所需的最大接种疫苗数量应该考虑在内。 
Evaluation of the SD bioline cholera rapid diagnostic test during the 2016 cholera outbreak in Lusaka, Zambia.

Tropical Medicine \& International Health. 2018 May 31; 



\title{
Evaluation of the SD bioline cholera rapid diagnostic test during the 2016 cholera outbreak in Lusaka, Zambia
}

\author{
John Mwaba', Eva Ferreras ${ }^{2}$, Elizabeth Chizema-Kawesa ${ }^{3}$, Daniel Mwimbe', Francis Tafirenyika ${ }^{4}$, Jean Rauzier ${ }^{5}$ \\ Alexandre Blake ${ }^{2}$, Ankur Rakesh ${ }^{2}$, Marc Poncin ${ }^{6}$, Savina Stoitsova ${ }^{7,8}$, Geoffrey Kwenda, Andrew S. Azman ${ }^{6,10}$, \\ Orbrie Chewe ${ }^{3}$, Micaela Serafini ${ }^{6}$, Chileshe Lukwesa-Musyani', Sandra Cohuet ${ }^{2}$, Marie-Laure Quilici ${ }^{5}$, \\ Francisco J. Luquero ${ }^{2}$ and Anne-Laure Page ${ }^{2}$ \\ 1 Department of Pathology and Microbiology, University Teaching Hospital, Lusaka, Zambia \\ 2 Epicentre, Paris, France \\ 3 Zambia Ministry of Health, Lusaka, Zambia \\ 4 Kanyama Clinic Laboratory, Lusaka, Zambia \\ 5 Institut Pasteur, Paris, France \\ 6 Médecins Sans Frontières, Geneva, Switzerland \\ 7 European Programme for Intervention Epidemiology Training, European Centre for Disease Prevention and Control, Stockholm, \\ Sweden \\ 8 National Institute of Public Health, National Institute of Hygiene, Warsaw, Poland \\ 9 Department of Biomedical Sciences, School of Health Sciences, University of Zambia, Lusaka, Zambia \\ 10 Department of Epidemiology, Johns Hopkins Bloomberg School of Public Health, Baltimore, Maryland
}

Abstract

OBJECTIVE To assess the performance of the SD Bioline Cholera Ag O1/O139 rapid diagnostic test (RDT) compared to a reference standard combining culture and PCR for the diagnosis of cholera cases during an outbreak.

METHODS RDT and bacterial culture were performed on site using fresh stools collected from cholera suspected cases, and from stools enriched in alkaline peptone water. Dried stool samples on filter paper were tested for V. cholerae by PCR in Lusaka (as part of a laboratory technology transfer project) and at a reference laboratory in Paris, France. A sample was considered positive for cholera by the reference standard if any of the culture or PCR tests was positive for V. cholerae O1 or O139. RESULTS Among the 170 samples tested with SD Bioline and compared to the reference standard, the RDT showed a sensitivity of $90.9 \%$ (95\% CI: 81.3-96.6) and specificity of $95.2 \%$ (95\% CI: 89.1-98.4). After enrichment, the sensitivity was $95.5 \%$ (95\% CI: 87.3-99.1) and specificity $100 \%$ (95\% CI: 96.5-100). CONCLUSION The observed sensitivity and specificity were within recommendations set by the Global Task Force for Cholera Control on the use of cholera RDT (sensitivity $=90 \%$; specificity $=85 \%$ ). Although the sample size was small, our findings suggest that the SD Bioline RDT could be used in the field to rapidly alert public health officials to the likely presence of cholera cases when an outbreak is suspected.

keywords cholera, rapid diagnostic test, diagnostic accuracy, outbreak

\section{Introduction}

Cholera is an important public health problem globally. More than 1.3 billion people are at risk, of whom 1.34.0 million contract cholera with an estimated 21000 143000 fatalities each year [1]. Most of the $\sim 150000$ cases reported each year to WHO are from Africa, Hispanolia and Asia, mainly due to lack of access to safe water, adequate sanitation and poor hygienic practices $[2,3]$. However, these figures are considered to be an underestimate for various reasons, such as fear of impact on trade and tourism, shortcomings of surveillance systems and inadequate timely detection capabilities [2].

Cholera is caused by toxigenic strains of Vibrio cholerae $\mathrm{O} 1$ and $\mathrm{O} 139$ bacteria. Identification of these bacteria in stool by culture or Polymerase Chain Reaction (PCR) is considered the gold standard for cholera diagnosis $[4,5]$. However, both these methods require good laboratory infrastructure and highly skilled staff that are often not readily available in areas where outbreaks occur. Shipment to a reference laboratory and a relatively long turn-around time for culture results, delay the 
confirmation of cholera diagnosis and implementation of response measures.

Rapid diagnostic tests (RDT) would have great value for the early detection of cholera outbreaks as tools for initial alert and for monitoring of outbreaks or seasonal peaks in endemic areas [6]. The use of RDTs could also help prioritise response to the disease in the most affected areas during large outbreaks. Although several immunochromatographic RDTs are commercially available, most of the recent diagnostic evaluations have focused on one product, Crystal VC (Arkray Health Care Private Limited, India; previously Span Diagnostics, India), which has shown high sensitivity of more than $90 \%$, but moderate specificity $(49-88 \%)$ when used directly on stools [7-11]. In addition, relatively high proportions of false-positive results with the O139 line have been reported by several teams [12-14]. The specificity of this test can be improved by a 4- to 6-h enrichment step in alkaline peptone water (APW), with the disadvantage of increasing the necessary logistics required and delaying the turn-around time for results to be available [13-15]. First data on two other tests, Artron Vibrio cholerae $\mathrm{O} 139$ and $\mathrm{O} 1$ Combo Test (Artron Laboratories Inc, Canada) and SD Bioline Cholera Ag O1/O139 RDT (Standard Diagnostics Inc., Korea), recently came from a retrospective analysis of routine data in Haiti comparing results of cholera RDTs to culture results [12]. Whereas the Artron test, like Crystal VC, showed very high sensitivity of $98.6 \%$ and modest specificity around $70 \%$, the SD Bioline RDT had a lower sensitivity of $81.1 \%$ but specificity of $92.8 \%$.

In a cholera outbreak that occurred in Lusaka, Zambia, from February to June 2016, the Ministry of Health $(\mathrm{MoH})$ of Zambia implemented an enhanced cholera surveillance system early in the course of the outbreak using the SD Bioline Cholera Ag O1/O139 rapid test. Following an emergency reactive oral cholera vaccine (OCV) campaign, organised in April 2016 by the $\mathrm{MoH}$, in collaboration with Médecins Sans Frontières, a study was implemented to estimate the vaccine effectiveness conferred by one dose of OCV [16]. Stool specimens collected from suspected cholera cases were sent to the laboratory for confirmation by culture and PCR, in addition to the RDT. We took advantage of this study to evaluate the diagnostic performance of SD Bioline RDT, aiming to identify an effective screening tool for cholera in an emergency situation or outbreak.

\section{Methods}

\section{Ethics}

This was a sub-study of the main study titled 'Effectiveness of one dose of killed whole cell cholera vaccine in response to an outbreak'. The protocol for the main study was approved by the Ethical Review Boards of the University of Lusaka (Zambia) and the Johns Hopkins School of Public Health (USA). Written informed consent was obtained from participants or their parents/guardians. Privacy and confidentiality of the data collected from participants was ensured both during and after the study.

\section{Study site and population}

This study was conducted in Lusaka district, Zambia, which has a population of approximately 2.3 million. The outbreak started on February 4th, 2016 and lasted until June 15th, 2016, and the MoH reported 1139 confirmed and/or suspected cholera cases and 20 cholerarelated deaths [17].

Two cholera treatment centres located in Kanyama and Bauleni and three cholera treatment units located in Chawama, Matero and George served as study sites. These clinics provided access to treatment to all patients coming from the high-risk areas in Lusaka. As part of enhanced surveillance, all suspected cholera cases (patients with acute non-bloody watery diarrhoea, ie. at least three liquid stools in $24 \mathrm{~h}$ ) gave a stool sample that was sent to Kanyama clinic laboratory for microbiological testing. The $\mathrm{MoH}$ enhanced capacity to carry out microbiological tests for detection and confirmation of cholera at Kanyama clinic laboratory by seconding a microbiologist from the National Reference Laboratory of the University Teaching Hospital (UTH).

Stool samples from patients with acute non-bloody diarrhea who presented from April 25th to June 15th 2016 to one of the treatment centres participating in the vaccine-effectiveness study and enrolled according to inclusion criteria [16] were included in the study. We excluded from this analysis patients enrolled after June 5 th, for whom SD Bioline rapid diagnostic testing could not be carried out because of a stock out of available kits.

\section{Laboratory procedures}

Specimen collection and preparation. Fresh stool samples were collected in a clean unchlorinated disposable container. The samples were immediately transported at room temperature (from Kanyama clinic) or in a cool box (from other study sites) to Kanyama clinic laboratory for testing.

Once the stool sample arrived in the laboratory, laboratory technologists performed cholera RDT and culture (see details below) directly from the sample. They also 
inoculated two drops in APW, which was incubated for $4-6 \mathrm{~h}$ at $37^{\circ} \mathrm{C}$. The RDT and culture were then repeated on the sample enriched in APW. Additionally, laboratory technologists placed two drops (approximately 80 $100 \mu \mathrm{l}$ ) of undiluted sample on Whatman 903 Protein Saver Card (GE Healthcare Ltd, Forest Farm, Cardiff UK), which was stored for further testing by PCR.

Rapid diagnostic test procedure. The testing was performed by qualified and trained laboratory technologists at Kanyama clinic laboratory and supervised by a microbiologist from the National Reference Laboratory. Technologists performing the rapid tests were blinded to clinical information and to the results of culture and PCR, which were performed subsequently.

SD Bioline Cholera Ag O1/O139 was used for testing on 170 samples following manufacturer's instructions when performing the tests and interpreting results. Briefly, the stool sample was collected using a cotton swab, which was then swirled in a sample collection tube pre-filled with $1 \mathrm{ml}$ of sample diluent buffer. Three to four drops of diluted sample were then added into the sample well of the test device using the cap with dropper nozzle of the collection tube. The test was read after 10 $20 \mathrm{~min}$ and interpreted as negative if only the control line appeared, positive for $\mathrm{O} 1, \mathrm{O} 139$ or both if the control line and the corresponding line(s) appeared, and invalid if the control line did not appear.

Stool culture. Stool samples were streaked out on Thiosulphate Citrate Bile Sucrose Agar (TCBS; Oxoid, UK) directly and after 4-6 h of incubation in APW. After 18-24 h incubation at $37^{\circ} \mathrm{C}$, TCBS plates were examined for the presence of yellow colonies suggestive of

$V$. cholerae. Single well-isolated yellow colonies were picked and streaked on Mueller-Hinton agar (Oxoid, UK) and incubated at $37^{\circ} \mathrm{C}$ for $24 \mathrm{~h}$. Colonies on Mueller-Hinton agar were tested for oxidase and, when positive for the oxidase reaction, testing with O1 polyvalent, O1 Inaba, O1 Ogawa and O139 antisera (Beckton Dickinson, USA) was performed as previously described [18].

PCR analysis. PCR was performed using stool samples stored on Whatman 903 Protein Saver Card kept at ambient temperature following previously described methods [13]. Total DNA extraction was performed by thermal shock method. Briefly, one circle containing dried stool was placed in a microtube and rehydrated with $150 \mu \mathrm{l}$ sterile water. Two hundred microlitres of $2 \%$ Chelex solution was then added and the sample was vortexed at high speed, boiled for $8 \mathrm{~min}$ and centrifuged for $2 \min [19]$.
Polymerase-chain reaction (PCR) was performed at Institut Pasteur, Paris, and in parallel at the UTH laboratory following same protocols as part of technology and methodology transfer. PCR was performed on $2 \mu \mathrm{l}$ of the supernatant to detect an intergenic spacer region specific of $V$. cholerae species using primer sequences (F-TTA AGC STT TTC RCT GAG AAT G and R-AGT CAC TTA ACC ATA CAA CCC G) [20]. On samples positive for $V$. cholerae, the $r f b$ gene was amplified for the identification of $V$. cholerae serogroups $\mathrm{O} 1$ and $\mathrm{O} 139$, as described by Hoshino [21]. On negative samples, the PCR was repeated on $4 \mu \mathrm{l}$ volumes. If still negative, a 16S rRNA PCR was performed on the samples to assess the presence of DNA and/or PCR inhibitors as described previously [13]. DNA from known V. cholerae O1/O139 strains supplied by Pasteur Institute, France were used as positive controls.

The technologists performing PCR were blinded to the RDT results and clinical information, but were aware of culture results.

\section{Statistical analysis}

For the reference standard, a true cholera case was defined as a suspected case with at least one culture or PCR positive for $V$. cholerae O1. A true negative case was defined as a suspected case with all culture and PCR results negative for $V$. cholerae O1. The sensitivity, specificity, positive predictive value (PPV), and negative predictive value (NPV) were estimated for both direct testing and testing after $4-6 \mathrm{~h}$ of enrichment in APW, by comparing the RDT results to the reference standard defined above. The estimates and 95\% confidence intervals for sensitivity, specificity, PPV, and NPV were estimated in Stata SE 14 (Stata Corporation, College Station, TX, USA) using the exact binomial method. The kappa coefficient was calculated to estimate the overall concordance between the rapid test and gold standard.

\section{Results}

From April 25th to June 15th, 2016, 251 patients with acute non-bloody diarrhoea were admitted and treated at health centres in the study area and 211/251 (84\%) patients were recruited in the parent vaccine effectiveness study during that period. Of these, 170/211 (81\%) had their stool samples tested with the SD Bioline RDT from April 25th to June 5th and were included in this evaluation (Figure 1). The majority of stool samples tested were from participants above 15 years of age and those who were severely dehydrated (Table 1 ). 
J. Mwaba et al. Evaluation of cholera RDT, Zambia

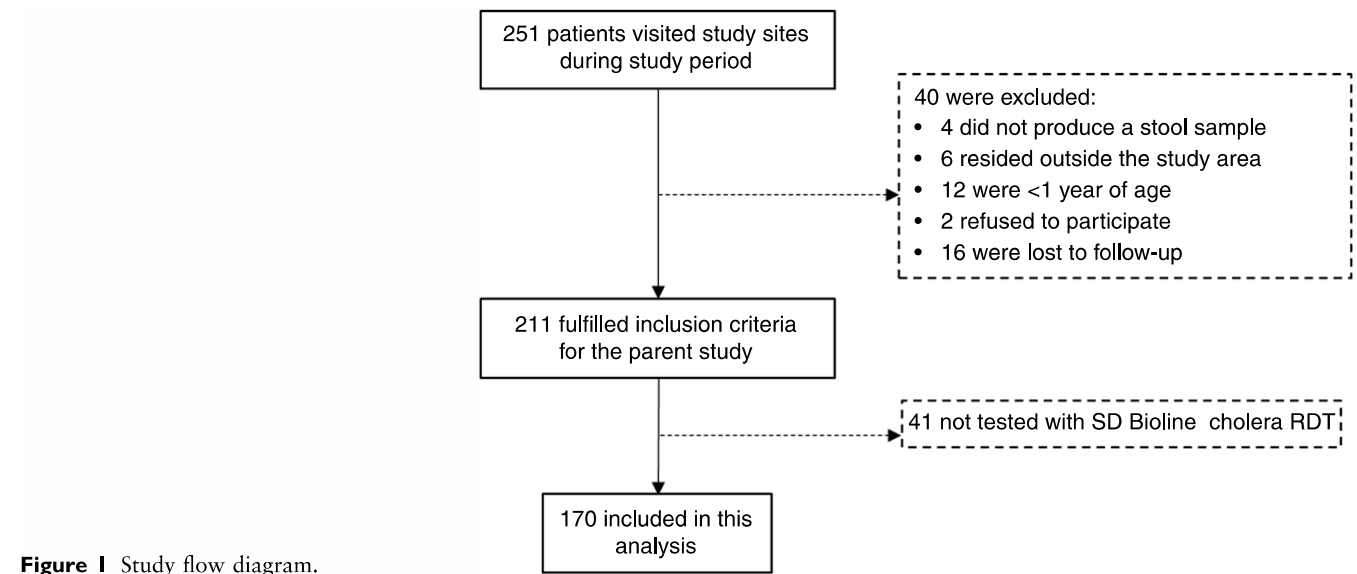

Table I Characteristics of the patients included in the study, overall and among those with cholera confirmed or not by the reference standard

\begin{tabular}{|c|c|c|c|}
\hline & $\begin{array}{l}\text { All } \\
(N=170) \\
n(\%)\end{array}$ & $\begin{array}{l}\text { Cholera } \\
(N=66) \\
n(\%)\end{array}$ & $\begin{array}{l}\text { No cholera } \\
(N=104) \\
n(\%)\end{array}$ \\
\hline Female gender & $81(47.7)$ & $28(42.4)$ & $53(51.0)$ \\
\hline Age in years, mean (SD) & $23.9(18.5)$ & $22.7(16.2)$ & $24.6(19.9)$ \\
\hline$<5$ & $38(22.4)$ & $11(16.7)$ & $27(26.0)$ \\
\hline $5-15$ & $21(12.4)$ & $11(16.7)$ & $10(9.6)$ \\
\hline$>15$ & $111(65.3)$ & $44(66.7)$ & $67(64.4)$ \\
\hline \multicolumn{4}{|l|}{ Dehydration* } \\
\hline A (no dehydration) & $11(6.5)$ & $0(0)$ & $11(10.6)$ \\
\hline B (mild) & $45(26.5)$ & $7(10.6)$ & $38(36.5)$ \\
\hline C (severe) & $113(66.5)$ & $59(89.4)$ & $54(51.9)$ \\
\hline \multicolumn{4}{|l|}{ Antibiotics } \\
\hline Within 2 days before admission & $18(10.6)$ & $8(12.1)$ & $10(9.6)$ \\
\hline At CTC before sample collection & $52(31.0)$ & $26(39.4)$ & $26(25.0)$ \\
\hline Received oral cholera vaccine & $26(15.3)$ & $6(9.1)$ & $28(26.9)$ \\
\hline
\end{tabular}

CTC, Cholera Treatment Centre; SD, standard deviation.

*1 with missing information

\section{Culture and PCR results}

Of the 170 samples tested with the SD Bioline RDT, 62 $(36.4 \%)$ samples were positive for $V$. cholerae $\mathrm{O} 1$

Ogawa by culture while $63(37.1 \%)$ samples were positive for V. cholerae $\mathrm{O} 1$ by PCR at the University Teaching Hospital (UTH), Lusaka, and 62 (36.4\%) samples positive for V. cholerae O1 by PCR at Institut Pasteur (IP), Paris. Three culture-negative specimens were detected by both PCR series, while 3 culture-positive specimens were missed by each of the PCR series. Finally,
66 patients $(38.8 \%)$ were considered positive for cholera by the reference standard and $104(61.2 \%)$ negative.

\section{Rapid diagnostic test performance}

Of the 170 samples tested with the SD Bioline RDT, 65 were positive for V.cholerae $\mathrm{O} 1$ by the RDT performed directly on stool and 63 by the RDT performed on APWenriched sample (Table 2). None of the RDTs showed a positive $\mathrm{O} 139$ line. The overall agreement between the 
J. Mwaba et al. Evaluation of cholera RDT, Zambia

Table 2 Diagnostic performance of SD Bioline performed as per manufacturer's recommendation (direct) or after enrichment in APW

\begin{tabular}{|c|c|c|c|c|c|c|}
\hline & \multicolumn{2}{|c|}{ Reference standard } & \multirow{2}{*}{$\begin{array}{l}\text { Sensitivity } \\
\%(95 \% \mathrm{CI})\end{array}$} & \multirow{2}{*}{$\begin{array}{l}\text { Specificity } \\
\%(95 \% \text { CI })\end{array}$} & \multirow{2}{*}{$\begin{array}{l}\text { PPV } \\
\%(95 \% \text { CI })\end{array}$} & \multirow{2}{*}{$\begin{array}{l}\text { NPV } \\
\%(95 \% \text { CI })\end{array}$} \\
\hline & Positive & Negative & & & & \\
\hline \multicolumn{7}{|l|}{ All $(\mathrm{N}=170)$} \\
\hline Direct & & & $90.9(81.3-96.6)$ & $95.2(89.1-98.4)$ & $92.3(83.0-97.5)$ & $94.3(88.0-97.9)$ \\
\hline Positive O1 & 60 & 5 & & & & \\
\hline Negative & 6 & 99 & & & & \\
\hline After enrichment & & & $95.5(87.3-99.1)$ & $100(96.5-100)$ & $100(94.3-100)$ & $97.2(92.0-99.4)$ \\
\hline Positive O1 & 63 & 0 & & & & \\
\hline Negative & 3 & 104 & & & & \\
\hline \multicolumn{7}{|c|}{ No prior antibiotics $(\mathrm{N}=101)$} \\
\hline Direct & & & $91.2(76.3-98.1)$ & $95.5(87.5-99.1)$ & $91.2(76.3-98.1)$ & $95.5(87.5-99.1)$ \\
\hline Positive O1 & 31 & 3 & & & & \\
\hline Negative & 3 & 64 & & & & \\
\hline After enrichment & & & $94.1(80.3-99.3)$ & $100(94.6-100)$ & $100(89.1-100)$ & $97.1(89.9-99.6)$ \\
\hline Positive O1 & 32 & 0 & & & & \\
\hline Negative & 2 & 67 & & & & \\
\hline
\end{tabular}

NPV, negative predictive value; PPV, positive predictive value.

RDT and the gold standard was kappa $=0.86$ for the direct test and kappa $=0.96$ after enrichment. The SD Bioline RDT had a sensitivity of $90.9 \%$ and specificity of $95.2 \%$ when performed directly on the stool sample, which increased to $95.5 \%$ and $100 \%$, respectively, after enrichment (Table 2). The performance estimates remained similar when analysis was restricted to patients without prior antibiotic consumption, which is sometimes considered as an exclusion criteria in diagnostic evaluations (Table 2).

\section{Discussion}

Our evaluation indicates that the SD Bioline Cholera Ag O1/O139 rapid test is promising, in terms of both sensitivity and specificity, for the diagnosis of cholera. With estimates of sensitivity at $90 \%$ and specificity at $95 \%$, the SD Bioline RDT matches the recommendations of minimal performance of $90 \%$ sensitivity and $85 \%$ specificity set forth in the Interim Technical Note on the use of cholera RDT published by the Global Task Force for Cholera Control (GTFCC) [6]. This test also matches the recommendations from a target product profile for cholera RDTs recently developed by the GTFCC [22], in terms of cost $(\sim 2 €$ per test), ease of use and clinical performance, although the confidence intervals are too wide due to the relatively small sample size in our study. This, together with the recent retrospective analysis of routine results in Haiti showing a more modest sensitivity $(81.1 \%)$ of the SD Bioline RDT compared to culture [12], highlight the need for additional prospective results on larger sample sizes and in different contexts.
The performance of the SD Bioline test reported here and in Haiti [12] suggest that the specificity of SD Bioline might be better than that of Crystal VC (49-88\%), but that its sensitivity might be lower than Crystal VC (consistently around $92-97 \%$ ) [7-11]. High sensitivity is generally considered the most important criterion for screening tests, while moderate specificity can be overcome by re-testing initially reactive samples using more specific confirmation assays. In the case of cholera, positive RDT results are currently considered as a cholera alert, which should prompt the shipment of samples to a central laboratory for confirmation by culture or PCR [6]. However, this confirmation step is sometimes challenging or not available, and further delays the implementation of response measures. The availability of a rapid test with high specificity might change the paradigm, so that positive RDT results could be considered as highly indicative of cholera, and targeted response measures can be started immediately. In this case, high specificity would be crucial, while moderate sensitivity could be overcome by testing a sufficient number of samples from suspected cholera cases to ensure that cholera is detected, as has historically been done with culture. Indeed, although considered the gold standard for cholera diagnosis, culture does not have perfect sensitivity [23]. In a recent study in South Sudan, the sensitivity of culture compared to PCR was estimated at $83 \%$ when performed on-site and $72 \%$ for a delayed culture at an international reference laboratory, which was lower than the sensitivity of SD Bioline estimated here [13].

In our study, the same number of positive results was detected by culture on site, PCR at UTH and PCR at IP, 
suggesting that PCR was not much more sensitive than culture in these conditions. In addition, each set of PCR taken individually would have missed three culture-positive results. It should be noted that culture was performed directly on fresh stools, whereas PCR was done later using stool samples stored on dry filter paper. In contrast, in the study mentioned above in South Sudan, both culture and PCR were done at a later stage from dry or wet filter paper [13]. This highlights the varying relative performance of culture and PCR depending on the sample collection and storage conditions and the need for a proper comparison of these methods. Whereas PCR could be more sensitive than culture when performed on the same volume of specimen stored in the same conditions, its added-value compared to good-quality culture on fresh stool might be limited, considering also the possible presence of PCR inhibitors in stools. However, considering the importance of the reference standard in diagnostic evaluations and the impact of an imperfect reference standard on performance estimates [7], the few additional cases identified by PCR do have their importance for proper patient classification. This should be considered when defining the reference standard for future evaluations of cholera rapid tests.

Enrichment in APW for $4-6 \mathrm{~h}$ has been reported to improve the performance of Crystal VC in several studies [13-15]. Although not recommended by the manufacturer, this enrichment step was also tested here with the SD Bioline RDT and shown to improve performance. The difference was small and, in practice, the addedvalue in performance might not be worth the added complexity and longer turn-around-time of this method for routine use. However, this method could potentially be very useful in cases where laboratory confirmation is not available and a specificity of $100 \%$ would be required.

This study had several limitations. First, the sample size was limited, in particular for cholera-confirmed cases, leading to wide confidence intervals in the estimates. Whereas studies set up in outbreak situations with comprehensive outbreak response measures often have limited sample sizes [11, 24], larger sample sizes can be obtained in endemic settings [12]. Alternately, performing meta-analyses using data from different studies and settings with similar study methods might be another way forward to get better insights into the performance of these tests. Second, the tests were done by trained laboratory technologists in a study setting, which might limit the possibility to extrapolate these results to more challenging field conditions with less-trained users.

Several factors, including those discussed above, could explain the higher sensitivity of the SD Bioline RDT in our study compared the analysis of routine data collected in Haiti [12]. First, it should be noted that due to the limited sample size in our study, the confidence intervals around the sensitivity estimates do overlap. Second, the specimen transfer method using a cotton swab might lack standardisation in the volume of specimen actually transferred into the sample collection tube, which could affect sensitivity of the assay. The format of the test kit was recently modified to include a dropper to transfer liquid stools, which should make the volume of specimen used in the assay more reproducible. Third, some characteristics of the study population, such as age, severity of disease, delay between onset and stool collection, or cholera endemicity, could have an impact on the bacterial load in stool specimens, which could in turn influence the clinical sensitivity if the bacterial loads are close to the analytical sensitivity of the assay. Population characteristics were not reported in the routine data from Haiti [12]. Finally, the reference standards used in these analyses were different, as was the type of data collection, prospective $v s$. retrospective.

In conclusion, these data on the performance of the SD Bioline Cholera Ag O1/O139 RDT suggest that this test could be used in the field to launch cholera alerts and maybe even start response measures, considering its good sensitivity (91\%) and high specificity (95\%). However, these results need to be reproduced with larger sample sizes and in different contexts representative of remote settings where cholera RDTs are most needed. Even if these evaluations confirm the good performance of this test, culture and PCR will remain paramount for the characterisation of cholera strains and understanding of global epidemiology of cholera in order to better fight this deadly disease and continuing pandemic.

\section{Acknowledgements}

We are grateful to all study participants. We wish to thank UTH microbiology members of staff who were very helpful to the team during running of PCR. We thank Children Kaluha and Iza Ciglenecki for their support to the study and Dr Roma Chilengi for critical reading of the manuscript. This work was supported by Médecins Sans Frontières - Operational Center Geneva.

\section{References}

1. Ali M, Nelson AR, Lopez AL, Sack DA. Updated global burden of cholera in endemic countries. PLoS Negl Trop Dis 2015 Jun: 9: e0003832.

2. World Health Organization. Cholera, 2015. Wkly Epidemiol Rec 2016: 91: 433-440. 
3. World Health Organization. Cholera, 2014. Wkly Epidemiol Rec 2015: 90: 517-528.

4. Dick MH, Guillerm M, Moussy F, Chaignat CL. Review of two decades of cholera diagnostics - How far have we really come? PLoS Negl Trop Dis 2012: 6: e1845.

5. Ramamurthy T, Nair GB, Quilici M-L. Cholera surveillance, rapid diagnostics and laboratory networks. Wkly Epidemiol Rec 2015: 90: 537-539.

6. Global Task Force on Cholera Control (2016). Interim technical note the use of cholera rapid diagnostic tests [Internet]. 1-5. (Available from: http://www.who.int/cholera/task force/Interim-guidance-cholera-RDT.pdf?ua=1) [7 Sep 2017]

7. Page A-L, Alberti KP, Mondonge V, Rauzier J, Quilici M-L, Guerin PJ. Evaluation of a rapid test for the diagnosis of cholera in the absence of a gold standard. PLOS ONE 2012 Jan: 7: e37360.

8. Ley B, Khatib AM, Thriemer $\mathrm{K}$ et al. Evaluation of a rapid dipstick (Crystal VC) for the diagnosis of cholera in Zanzibar and a comparison with previous studies. PLOS ONE 2012: 7: 3-10.

9. Mukherjee P, Ghosh S, Ramamurthy T et al. Evaluation of a rapid immunochromatographic dipstick kit for diagnosis of cholera emphasizes its outbreak utility. Jpn J Infect Dis 2010: 63: 234-238.

10. Boncy J, Rossignol E, Dahourou G et al. Performance and utility of a rapid diagnostic test for cholera: notes from Haiti. Diagn Microbiol Infect Dis 2013 Aug: 76: 521-523.

11. Harris JR, Cavallaro EC, De Nobrega AA et al. Field evaluation of crystal VC rapid dipstick test for cholera during a cholera outbreak in Guinea-Bissau. Trop Med Int Health 2009: 14: 1117-1121.

12. Matias WR, Julceus FE, Abelard C et al. Laboratory evaluation of immunochromato- graphic rapid diagnostic tests for cholera in Haiti. PLoS ONE 2017: 12: e0186710.

13. Ontweka LN, Deng LO, Rauzier J et al. Cholera rapid test with enrichment step has diagnostic performance equivalent to culture. PLOS ONE 2016: 11: e0168257.

14. George CM, Rashid M, Sack DA et al. Evaluation of enrichment method for the detection of Vibrio cholerae O1 using a rapid dipstick test in Bangladesh. Trop Med Int Health 2014 Mar: 19: 301-307.
15. Wang X-Y, Ansaruzzaman M, Vaz R et al. Field evaluation of a rapid immunochromatographic dipstick test for the diagnosis of cholera in a high-risk population. BMC Infect Dis 2006: 6: 17 .

16. Ferreras E, Chizema-Kawesha E, Blake A et al. Single-dose cholera vaccine in response to an outbreak in Zambia. $N$ Engl J Med 2018 Feb 8: 378: 577-579.

17. Poncin M, Zulu G, Voute C et al. Implementation research: reactive mass vaccination with single-dose oral cholera vaccine, Zambia. Bull World Health Organ 2017 96: 86-93.

18. Centers for Disease Control and Prevention. Laboratory methods for the diagnosis of epidemic dysentery and cholera. In: CDC, editor. Laboratory Methods for the Diagnosis of Epidemic Dysentery and Cholera. CDC: Atlanta, GE, 1999.

19. Debes AK, Ateudjieu J, Guenou E et al. Clinical and environmental surveillance for vibrio cholerae in resource constrained areas: application during a 1-year surveillance in the far North Region of Cameroon. Am J Trop Med Hyg 2016 Mar 2: 94: 537-543.

20. Chun J, Huq A, Colwell RR. Analysis of 16S-23S rRNA intergenic spacer regions of Vibrio cholerae and Vibrio mimicus. Appl Environ Microbiol 1999 May: 65: 2202-2208.

21. Hoshino K, Yamasaki S, Mukhopadhyay AK et al. Development and evaluation of a multiplex PCR assay for rapid detection of toxigenic Vibrio cholerae O1 and O139. FEMS Immunol Med Microbiol 1998 Mar: 20: 201-207.

22. Global Task Force on Cholera Control. Target Product Profile (TPP) for the development of improved Cholera rapid diagnostic tests [Internet]. 2017; 1-19. (Available from: http://www.who.int/cholera/task_force/cholera-rapid-diagnos tic-test.pdf?ua=1) [13 Oct 2017]

23. Alam M, Hasan NA, Sultana M et al. Diagnostic limitations to accurate diagnosis of cholera. J Clin Microbiol 2010: 48: 3918-3922.

24. Bwire G, Orach CG, Abdallah D et al. Alkaline peptone water enrichment with a dipstick test to quickly detect and monitor cholera outbreaks. BMC Infect Dis 2017: 17: 726

Corresponding Author Anne-Laure Page, Epicentre, 8 rue Saint-Sabin, 75011 Paris, France. E-mail: anne-laure.page@ epicentre.msf.org 

Alternative observational designs to estimate the effectiveness of one dose of oral cholera vaccine in Lusaka, Zambia.

Epidemiology \& Infection 



\section{Alternative observational designs to estimate the effectiveness of one dose of oral cholera vaccine in Lusaka, Zambia.}

E. Ferreras ${ }^{1 *}$, A. Blake ${ }^{1}$, O. Chewe ${ }^{2,3}$, J. Mwaba ${ }^{4,5}$, G. Zulu $^{2}$, M. Poncin ${ }^{6}$, A. Rakesh ${ }^{1}$, A. L. Page ${ }^{1}$, M. L. Quilici ${ }^{7}$, A. S. Azman ${ }^{8}$, S. Cohuet ${ }^{1}$, I. Ciglenecki ${ }^{6}$, K. Malama ${ }^{2}$, E. Chizema-Kawesha ${ }^{2}$, F. J. Luquero ${ }^{1,9}$

1. Epicentre, Paris, France

2. Ministry of Health, Lusaka, Zambia

3. Zambia National Public Health Institute, Lusaka, Zambia

4. Department of Pathology and Microbiology, University Teaching Hospital, Lusaka, Zambia

5. Centre For Infectious Diseases Research in Zambia

6. Médecins Sans Frontières, Geneva, Switzerland

7. Institut Pasteur, Paris, France

8. Department of Epidemiology, Johns Hopkins Bloomberg School of Public Health, Baltimore, MD, USA.

9. Department of International Health, Johns Hopkins Bloomberg School of Public Health, Baltimore, MD, USA.

\section{Corresponding author:}

Eva Ferreras

Calle las Saleguillas 8, 28492 Mataelpino (Spain)

ferreras_eva@yahoo.fr

This peer-reviewed article has been accepted for publication but not yet copyedited or typeset, and so may be subject to change during the production process. The article is considered published and may be cited using its DOI $10.1017 / \mathrm{S} 095026882000062 \mathrm{X}$.

Epidemiology \& Infection is published by Cambridge University Press. 


\section{Summary}

We conducted a matched case-control (MCC), test-negative case-control (TNCC), and case-cohort study in 2016 in Lusaka, Zambia, following a mass vaccination campaign. Confirmed cholera cases served as cases in all three study designs. In the TNCC, control-subjects were cases with negative cholera culture and PCR results. Matched controls by age and sex were selected among neighbors of the confirmed cases in the MCC study. For the case-cohort study, we recruited a cohort of randomly selected individuals living in areas considered at risk of cholera. We recruited 211 suspected cases (66 confirmed cholera cases and 145 non-cholera diarrhoea cases), 1055 matched controls and a cohort of 921. Adjusted vaccine effectiveness of one dose of OCV was $88.9 \%$ (95\% confidence interval (CI): 42.797.8\%) in the MCC study, $80.2 \%$ (95\% Cl: $16.9-95.3 \%)$ in the TNCC design and $89.4 \%$ (95\% Cl: $64.6-$ 96.9\%) in the case-cohort study. Three study designs confirmed the short-term effectiveness of single dose OCV. Major healthcare-seeking behavior bias did not appear to affect our estimates. Most of the protection among vaccinated individuals could be attributed to the direct effect of the vaccine. 


\section{Introduction}

Observational studies are often used to better understand how vaccines perform across a variety of real populations with different epidemiologic and geographical settings; especially as new vaccines are introduced into routine immunization schedules and the number and timing of doses changes. The evidence base produced from these evaluations is key to setting vaccine policy $(1,2)$. Evaluating vaccine effectiveness typically requires detecting and recruiting individuals with the disease of interest. For many epidemic-prone diseases, like cholera, outbreaks provide a critical window where vaccine evaluations may be feasible(3-5).

Among the study designs to evaluate vaccine effectiveness (VE) during outbreaks (6) case-control studies are the most used because of their practical design for rare diseases, as the odds ratio (OR) approximates RR and therefore can be used to estimate VE $(7,8)$. These studies are relatively quick to conduct and less expensive than cohort studies. In the traditional case-control design, controls are randomly selected members of the study population who have not developed the disease of interest prior to their inclusion. In the test-negative case-control (TNCC), the analysis is limited to those seeking health care for similar symptoms; with controls being those who test negative for the disease of interest. Test-negative controls are a good alternative in emergency situations because of their time-efficiency (9). The case-cohort is a variant of the case-control design where controls are random sampled from the initial population at risk, and may thus include both cases and non-cases. Unlike the case-control design, sampling is done a priori without regard to case status or time, providing an estimate of the RR (10). Moreover, this approach allows taking into account the variable person-time at risk in vaccinated and unvaccinated states and provides a VE estimate incorporating some degree of indirect effects (3).

Irrespective of the study design selected, an accurate estimate of VE requires the accurate ascertainment of susceptibility to the infection, vaccination status, and disease status among the study population and comparability in other characteristics among vaccinees and non-vaccinees (11). 
The absence of randomization between study groups in observational studies may lead to differences that affect their risk of infection, for reasons other than their vaccination status. If not adequately measured and adjusted for in analyses, these differences may confound the association between vaccination and the outcome.

Confounders are associated with both probability of vaccination and with the outcome. Solutions at the design-level, such as matching, or at analysis-level, through stratification or multi-variable analysis, can control confounding. In matched case-control (MCC), community control recruitment facilitates matching on key confounders such as age, neighborhood, and time (12). Spatial matching helps controlling for local variations not only in risk but also in vaccination coverage.

In MCCs, where controls are selected from the community, it is possible that they have different access to care or health care-seeking behavior compared to cases, which could lead to biased estimates of VE. This is not the case for the TNCC controls, since they are selected following care seeking (13). However, TNCC is more sensitive to disease misclassification and, therefore, risk of selection bias (14).

In February 2016 in Lusaka, Zambia a cholera outbreak was declared after 4 years with no confirmed cholera in the city. An reactive OCV campaign (15) was carried out between 9 and 25 April 2016 (16). Due to a global vaccine shortage, the Ministry of Health with support from Médecins Sans Frontières (MSF) and the World Health Organization decided to use a single dose regimen of oral cholera vaccines (OCV) to vaccinate high-risk areas to halt transmission within Lusaka and limit the probability of spread within the country.

We conducted a VE study in Lusaka, Zambia (Figure 1), using three methodologies: MCC, TNCC, and case-cohort design, to quantify the short-term protection provided by one dose of OCV (Shanchol ${ }^{\ominus}$, Shantha Biotechnics, Hyderabad, India). This setting provided a unique opportunity to measure the effect of the vaccine comparing estimates of VE from different designs to better understand the 
robustness of conclusions from the primary analysis published elsewhere (4) and to inform the design of future observational studies of OCV VE accounting for different possible source of biases.

Figure 1:Timeline, Lusaka, Zambia, 2016. *Test-negative ${ }^{* *}$ Case-control ${ }^{* * *}$ Case-cohort

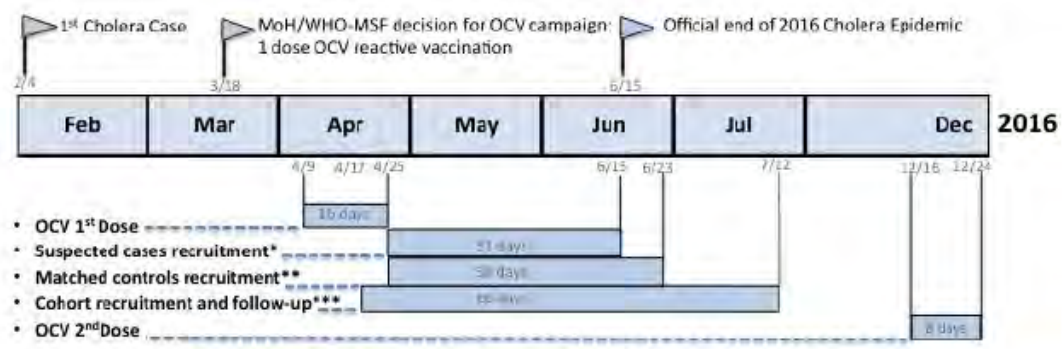

\section{Methods}

\section{Study area and cholera surveillance}

Cholera is endemic in Zambia. The high risk areas in Lusaka, defined from historical data and access to water and sanitation conditions, represent around $35 \%$ of the city's population, mainly in the western peri-urban areas of the city (17). From April 14, 2016 until the end of the outbreak, the surveillance system was reinforced with the use of standardized line-lists and case definitions in the five cholera treatment centers (CTC), located in the higher risk areas for cholera. 


\section{Definitions and laboratory confirmation}

A suspected cholera case was any person admitted in any of the CTC between 25 April and 15 June 2016 (official declaration of the end of the outbreak) with acute watery diarrhoea (at least three watery stools in a 24-hour period). All suspected cholera cases were included in the study if (1) resided in the study area since 9 April 2016 (first day of vaccination (FDV)) (2) was older than 12 months on FDV (3) diarrhoea started after FDV; and (4) her/his residence could be located by the study team after discharge

During admission, a stool sample was collected from all suspected cases in an unused and unchlorinated container. Fresh stools were used to perform culture on site, at Kanyama clinic laboratory, using standard methods (18). If written consent was obtained, two drops of stool sample were placed on Whatman 903 filter paper for subsequent PCR testing at the University Teaching Hospital (Lusaka, Zambia) and Institut Pasteur (Paris, France), using previously described methods (19)

All suspected cholera cases were included and divided into two groups based on cholera culture/PCR results. Confirmed cholera cases (culture and/or PCR positive result) were compared with noncholera diarrhoea controls (negative to culture and PCR).

A neighbor of the same sex and within the same age group (1-4, 5-9, 10-19, 20-29, 30-39, and $\geq 40$ years) as the confirmed cholera case was eligible to be a matched control if s/he: resided in the study area since FDV; was at least 12 months; had not sought treatment for diarrhoea between 1 January 2016 and the date of onset of the matched case's diarrhoea; and would have sought treatment in a CTC if severe, watery diarrhoea had developed.

\section{Study design}

We performed a case control study and a case-cohort study. After obtaining signed consent, study staff conducted a structured face-to-face interview with each suspected case at the CTC between 25 
April and 15 June 2016. After interviewing the cases, five neighbor-controls were selected per confirmed cholera case and were interviewed at their houses the same week their matched case was interviewed. In cases where the participant was a minor, study teams interviewed the parents/guardian in the presence of the minor, when possible.

From 17 April to 25 May 2016 we recruited a cohort of 906 randomly selected individuals living in areas considered at high risk of cholera transmission (some of them targeted and some of them nontargeted by the reactive OCV campaign). Cohort members were selected from townships with a probability proportional to their population size. We randomly selected households by drawing GPS positions in georeferenced polygons of the township boundaries (20). One person aged 12 months and above, from each household was randomly chosen. Participants had same eligibility criteria than described above.

Study staff first interviewed the selected cohort participants at their houses and then followed them up 24 July 2016. The occurrence of episodes of diarrhoea, both medically attended and nonmedically attended, and vaccination of non-previously vaccinated participants was checked during follow-up. Study participants recorded on the master national line list of suspected cholera cases at the end of the study would be considered as cases.

Participants were asked whether they had been vaccinated - including when, where and whether it was completely ingested - after showing a picture of a vaccine vial and of an adult taking the vaccine. The interviewers provided to each participant details of the vaccination campaign to ensure an adequate identification of the antigen. The vaccination card was systematically checked and photographed if it was provided.

Vaccination status, clinical, demographic, socioeconomic, and environmental variables were ascertained through electronic questionnaires using Kobo Toolbox software 1.4.8 (Cambridge, MA, USA). 


\section{Analysis}

The primary analysis of vaccine effectiveness was based on the MCC design, which has been published elsewhere (4). Here, we reanalysed the data adding two more approaches to estimate the effectiveness of one dose of OCV: a TNCC and a case-cohort design.

We assessed the protection conferred by the intake of one dose of vaccine against stool culture or/and PCR confirmed cholera. In our analyses a person was considered to be vaccinated seven days after ingesting the vaccine (without spit/vomit).

For the TNCC and the MCC, we compared the odds of vaccination between confirmed cholera cases and controls (non-cholera diarrhoea or matched) using univariate and multivariable conditional logistic regression models. We calculated the VE as (1-OR) x 100.

In the multivariate analysis, we explored the potential confounding effect of different well-known risk factors for cholera (Supplementary Tables S1 and S3 are available as Supplementary Material on the Cambridge Core website) to obtain adjusted VE estimates (Table 1). We defined variables as possible confounders when they were associated ( $p$-value less than 0.2 ) with the outcome and with the exposure (vaccination status). We also considered as potential confounders variables that modified the VE in more than $5 \%$ in the bivariate models (including vaccination status). We included all possible confounders in the final adjusted model.

All P-values and 95\% $\mathrm{Cl}$ were two-sided. We used $\mathrm{R}$ statistical software (version 3.2.3) and the survival package for the main analyses. Missing data were treated as described in the Supplementary Material.

For the case-cohort, we estimated unadjusted and adjusted hazard ratios (HR) of medically attended cholera comparing those who received the vaccine to those who did not. The hazard ratio (HR) was then translated into overall VE through using the formula: $V E=(1-H R) \times 100$. We used proportional hazards models with vaccination as an independent variable and a time origin of 9 April 
2016 (FDV). Cases that did not come from the cohort contributed person-time 0.01 days before his/her time of symptom onset following standard case-cohort analyses (10). To be conservative, individuals in the cohort reporting diarrhoea during study follow-up with no evidence of confirmed cholera (through matching with the line list) remained 'at risk' for cholera after the date of diarrhoea. We explored violations of non-proportionality of hazards visually and through generalized regression of the Schoenfeld residuals of vaccination with (log) time (21).

Adjusted estimates are using multiple imputation of missing values for all designs.

\section{Ethical aspects}

The study protocol was approved by the Ethical Review Boards of the University of Zambia and the Johns Hopkins Bloomberg School of Public Health (USA). Privacy and confidentiality of the data collected from participants was ensured both during and after the study. Informed consents were signed by all participants.

\section{Results}

From 25 April to 15 June 2016, 251 patients with acute watery diarrhoea were admitted and treated at health centers in the study area and of these, 211 of these suspected cholera fulfilled inclusion criteria (Figure 2). 
Figure 2. Study flowchart

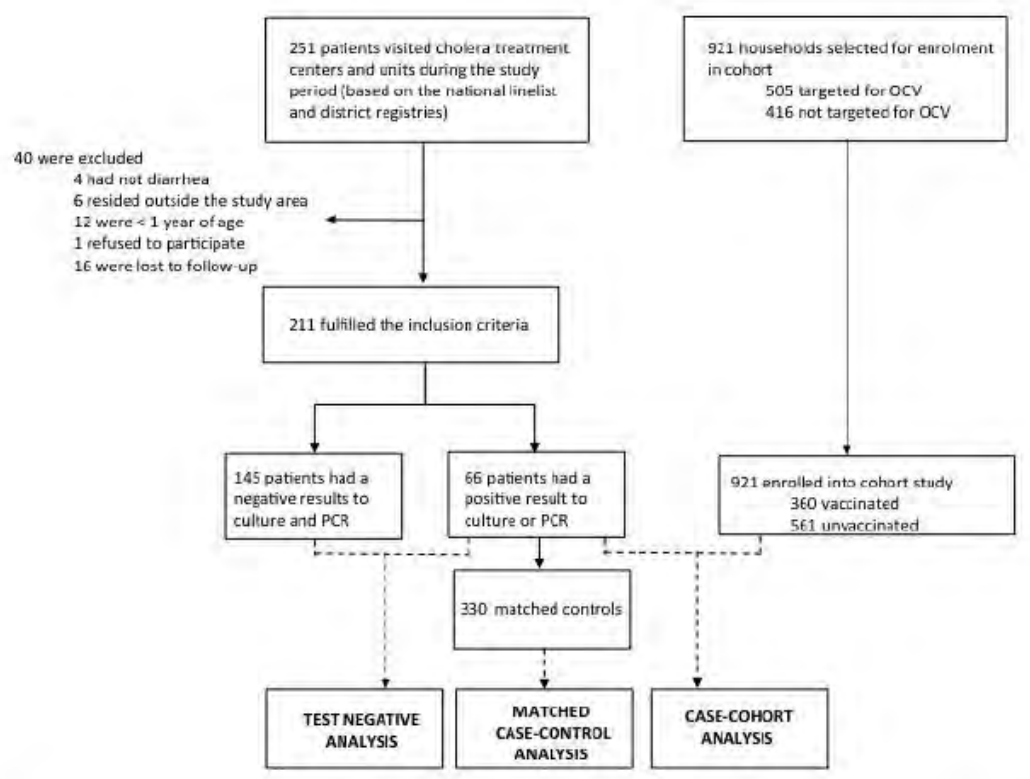

The mean age of the suspected cholera cases included in the study was 21.6 years (standard deviation: 18.2 ), with $28 \%(n=59)$ of them being children under 5 years. Half $(50 \%)$ of the suspected cases were females, although among confirmed cases, $42 \%$ were females. $82 \%$ of the cases had some degree of dehydration at admission ( $55 \%$ were severely dehydrated). Severe dehydration was more common among confirmed cholera cases than among non-cholera diarrhoea cases ( $89 \%$ vs $39 \%$ ) (Supplementary Material).

\section{Test-negative case-control analysis}

Among the 211 suspected cholera cases included in study, 66 (31\%) had positive culture and/or PCR results for $V$. cholerae 01, 63 unvaccinated and 3 vaccinated. All confirmed cases had $V$. cholerae 01 serotype Ogawa. From the 145 non-cholera diarrhoea cases, 39 were vaccinated and 106 unvaccinated. Other socio-demographic characteristics of the confirmed cholera cases and the non- 
cholera diarrhoea cases are detailed in the Supplementary Material (Table S1). Using unadjusted and adjusted logistic regression models, VE was $87.1 \%$ (95\% confidence interval (CI): 62.4-97.0\%) and 80.2\% (95\% Cl: 16.9-95.3) respectively. (Table 1)

Matched case-control analysis

In total, 330 matched controls were interviewed of which 44 were vaccinated. The median distance between cases and their matched control households was $49 \mathrm{~m}$ (interquartile range: 16.8- 119) Characteristics of the confirmed cholera cases and their matched controls were similar except that cases more frequently reported household members with recent cholera and sharing a water source/latrine with cholera/diarrhoea patients . (Table S1)

Vaccination with one dose of OCV was associated with protection against cholera, in the crude analysis ( $\mathrm{VE}=84.7 \%$; $95 \% \mathrm{Cl}$ : 27.0-96.6\%) and after adjustment for potential confounders (VE= 88.9\%; 95\% Cl: $42.7-97.8 \%)$ (Table 1).

\section{Case-cohort analysis}

Overall 360 vaccinated and 561 unvaccinated individuals were recruited as part of the cohort (100\% participation). A total of 811 participants (88\%) were successfully contacted for follow-up at the end of the outbreak. 28 cases of acute watery diarrhoea were reported within this cohort, but none of them required admission to a health structure and none appeared in the CTC registers. 66 cholera confirmed cases recruited through passive surveillance were included in the case-cohort analysis (same as in the MCC and TND).

The crude VE using the case-cohort design was $86.7 \%$ (95\% Cl: 86.6-95.9\%) and the adjusted VE was 89.4\% (95\% Cl: $64.6-96.9 \%)$ (Table 1). 


\section{Discussion}

This study aims to measure the short-term protection of a single dose of OCV. The three study designs found comparable levels of protection and confirm that single dose of OCV confers high protection against medically attended cholera infection for at least two months following immunization.

A recent study in Odisha (India) that used a TNCC as their main analysis and a cohort analysis used to validate the main results, showed that the incidence of non-cholera diarrhoea among vaccinees was 2.7 times higher than among non-vaccinees, indicating different risk of diarrhoeal diseases or heterogeneity in healthcare-seeking behavior between vaccinees and unvaccinees (22).

Our analysis using the TNCC design found comparable VE estimates as the MCC. It provides reassurance that major HSB bias was not at play. Moreover, the indicator bias analysis showed that the odds of vaccination did not vary significantly between non-cholera diarrhoea cases and their controls, as described earlier (4).

Self-reported vaccination was then not associated with non-cholera diarrhoea, which supports the robustness of our VE estimates regarding healthcare-seeking behavior bias.

We considered the analyses restricting the non-cholera diarrhoea to those with moderate to severe diarrhoea and found no differences in the estimation but in IC because of the reduced sample size. Unfortunately, we did not enroll enough cases to obtain stable VE estimates when stratifying by age and severity to explore possible effect modification.

Similarly, the VE estimates from our case-cohort study were similar to those reported in the primary matched case-control analyses. Spatial matching, if done at the appropriate scale, should control for the differences in vaccine coverage thus providing an estimate of the direct vaccine protection.(23) The similarity of the VE from both designs suggests that the protection among vaccinated individuals was mostly attributable to the direct effect of the vaccine in Lusaka. However, we cannot discount 
the possibility that the spatial matching was imperfect, allowing the inclusion of controls from areas with different vaccine coverage, and thus allowing the inclusion of indirect protection in the MCC VE estimates. A sensitive analysis with different neighborhood sizes during a cohort study in Zanzibar suggest that herd protective effect remained stable up to the size of $500 \mathrm{~m}$ radius neighborhood (24). In our sensitive analysis, the estimates remain stable when removing those with a distance more than $150 \mathrm{~m}$ and same for those with a distance more than $300 \mathrm{~m}$.

Our VE estimates are almost identical to the short-term single-dose effectiveness estimated from a CC study in South Sudan (87\%) (3) but are higher than efficacy estimated in a randomized clinical trial in Bangladesh against severe cholera (63\%) (25). Several factors might explain this difference, including different follow-up periods, different age distribution (in our study, and that of South Sudan, tended to be much older ( $17 \%$ under 5 years old) than in the Bangladesh study ( $58 \%$ of cases under 5 years old), severity profile of cases (our study includes proportionally more severe cases) and different dominant mode of transmission. Furthermore, we cannot exclude that herd protection was confounding the true direct effect of cholera vaccine in Bangladesh, since studies have consistently shown higher direct protection in areas with lower vaccination coverage (26)

Two main biases may affect our results; misclassification and selection bias linked with the nonrandom distribution of the vaccine. To reduce the chances of misclassifying case status, we used both culture and PCR, which is more sensitive and robust to antibiotic use before sample collection. In addition to the 62 cases confirmed by culture, we detected four additional cases by PCR that were negative by culture. During control ascertainment, we exclude those who sought treatment for diarrhoea between 1 January 2016 and the date of onset of the matched case's diarrhoea because they were not at risk and might bias the VE estimation. Learning from previous vaccination studies $(3,5)$, we set up several procedures to limit the risk of misclassification of vaccination status, including the use of visual aids and asking for proof of vaccination. Unfortunately, the vaccination card retention (52\%) was lower, due to the poor quality of the vaccination cards, than previously 
published studies $(5,27)$. It is possible that study participants were not representative of the at-risk population; however, our wide coverage of enhanced surveillance in the key areas of Lusaka, combined with the fact that vaccine coverage in the controls was similar to vaccine coverage estimated in the general (targeted) population, provides reassurance that these biases were minimal.

\section{Conclusions}

Our three different designs provide similar estimates of high level of short-term protection for one dose of OCV and confirm that this could be an effective tool to prevent cholera during outbreaks, even in areas with little to no recent exposure to cholera and provides high short-term protection. This finding is important to support recommendations for the use of the vaccine in response to outbreaks, where high-levels of short-term protection can greatly determine the impact of any campaign.(4).

Estimates from MCC design are more precise because we maximized statistical power and efficiency by matching up to five community controls to each case by age group, neighborhood and calendar time. Alternative study designs (TNCC and case-cohort) yielded similar estimates of VE than MCC design with the advantage of having a better control related to HSB and to detect eventual indirect effects of the vaccine. The TNCC are a good alternative in emergency situations, especially if community controls recruitment is compromised (i.e. security reasons). Case-cohort design is an adequate option when there are few cases after vaccination to improve the study power.

Cholera outbreaks are still a major public health threat, and nowadays OCV is considered as part of the public health measures available for outbreak response. But refining the assessment of the impact of OCV with observational studies design, especially to measure the long-term protection conferred by a single dose of $\mathrm{OCV}$, is still necessary to learn how to use best cholera vaccines. 


\section{Acknowledgements:}

We would like to thank Dr Mohammad Ali for his critical reading of the manuscript.

Thanks are also due to the field work team: Hannah Mzyece, Tangu Daka, Nicholas Mushimba,

Michael Mwamba, Karen Chikonka, Christine Zulu, Agnes Ndilla, Mulambo Mulonda, Melody Kalombo, Kakoma Samudata, George Kapapi, Christabel Nkunika, Evans Mwango, Ellen Imasiku, Gwenie Nseluke, Mercy Mutambo, Sarah Zymba, Loveness Moonde, Nyambe Sinyange, Francis Tafirenyika and Daniel Mwiimbe for their intense and excellent work.

And specially to thank all people we interviewed for their patience.

\section{Conflict of interest: None}

\section{References}

1. Begg N, Miller E. Role of epidemiology in vaccine policy. Vaccine. 1990 Jun;8(3):180-

2. Orenstein WA, Bernier RH, Hinman AR. Assessing vaccine efficacy in the field. Further observations. Epidemiologic Reviews. 1988;10:212-41.

3. Azman AS, Parker LA, Rumunu J, Tadesse F, Grandesso F, Deng LL, et al. Effectiveness of one dose of oral cholera vaccine in response to an outbreak: a case-cohort study. Lancet Global Health. 2016 Nov;4(11):e856-63.

4. Ferreras E, Chizema-Kawesha E, Blake A, Chewe O, Mwaba J, Zulu G, et al. SingleDose Cholera Vaccine in Response to an Outbreak in Zambia. The New England Journal of Medicine. 2018 08;378(6):577-9.

5. Luquero FJ, Grout L, Ciglenecki I, Sakoba K, Traore B, Heile M, et al. Use of Vibrio cholerae vaccine in an outbreak in Guinea. The New England Journal of Medicine. 2014 May 29;370(22):2111-20.

6. Orenstein WA, Bernier RH, Dondero TJ, Hinman AR, Marks JS, Bart KJ, et al. Field evaluation of vaccine efficacy. Bulletin of the World Health Organization. 1985;63(6):1055- 
68.

7. Greenland S, Thomas DC. On the need for the rare disease assumption in case-control studies. American Journal of Epidemiology. 1982 Sep;116(3):547-53.

8. Zhang J, Yu KF. What's the Relative Risk?: A Method of Correcting the Odds Ratio in Cohort Studies of Common Outcomes. JAMA. 1998 Nov 18;280(19):1690-1.

9. Franke MF, Jerome JG, Matias WR, Ternier R, Hilaire IJ, Harris JB, et al. Comparison of two control groups for estimation of oral cholera vaccine effectiveness using a case-control study design. Vaccine. 2017 13;35(43):5819-27.

10. Barlow WE, Ichikawa L, Rosner D, Izumi S. Analysis of case-cohort designs. Journal of Clinical Epidemiology. 1999 Dec;52(12):1165-72.

11. Orenstein WA, Bernier RH, Hinman AR. Assessing vaccine efficacy in the field. Further observations. Epidemiologic Reviews. 1988;10:212-41.

12. Chen RT, Orenstein WA. Epidemiologic methods in immunization programs. Epidemiologic Reviews. 1996;18(2):99-117.

13. Ali M, You YA, Sur D, Kanungo S, Kim DR, Deen J, et al. Validity of the estimates of oral cholera vaccine effectiveness derived from the test-negative design. Vaccine. 2016 Jan 20;34(4):479-85.

14. De Smedt T, Merrall E, Macina D, Perez-Vilar S, Andrews N, Bollaerts K. Bias due to differential and non-differential disease- and exposure misclassification in studies of vaccine effectiveness. PloS One. 2018;13(6):e0199180.

15. WHO. Oral cholera vaccines in mass immunization campaigns. Guidance for planning and use [Internet]. Available from:

http://www.who.int/cholera/vaccines/AddendumGuideVaccinationForShanchol050913.pdf? ua $=1$

16. Oral Cholera Vaccine stockpile for cholera emergency response. [Internet]. WHO; 2013. Available from: http://www.who.int/cholera/vaccines/Briefing_OCV_stockpile.pdf

17. Olu O, Babaniyi O, Songolo P, Matapo B, Chizema E, Kapin'a-Kanyanga M, et al. Cholera epidemiology in zambia from 2000 to 2010: implications for improving cholera prevention and control strategies in the country. East African Medical Journal. 2013 Oct;90(10):324-31.

18. Isolation of Vibrio cholerae from Fecal Specimens - laboratory-methods-for-thediagnosis-of-vibrio-cholerae-chapter-4.pdf [Internet]. [cited 2016 Oct 28]. Available from: https://www.cdc.gov/cholera/pdf/laboratory-methods-for-the-diagnosis-of-vibrio-choleraechapter-4.pdf 
19. Hoshino K, Yamasaki S, Mukhopadhyay AK, Chakraborty S, Basu A, Bhattacharya SK, et al. Development and evaluation of a multiplex PCR assay for rapid detection of toxigenic Vibrio cholerae 01 and 0139. FEMS Immunology and Medical Microbiology. 1998 Mar;20(3):201-7.

20. Pearson AL, Rzotkiewicz A, Zwickle A. Using remote, spatial techniques to select a random household sample in a dispersed, semi-nomadic pastoral community: utility for a longitudinal health and demographic surveillance system. International Journal of Health Geographics [Internet]. 2015 Nov 14 [cited 2017 Apr 11];14. Available from: http://www.ncbi.nlm.nih.gov/pmc/articles/PMC4647289/

21. Hosmer DW, Lemeshow S, May S. Applied Survival Analysis: Regression Modeling of Time-to-Event Data [Internet]. Hoboken, NJ, USA: John Wiley \& Sons, Inc.; 2008 [cited 2017 Apr 11]. (Wiley Series in Probability and Statistics). Available from: http://doi.wiley.com/10.1002/9780470258019

22. Wierzba TF, Kar SK, Mogasale VV, Kerketta AS, You YA, Baral P, et al. Effectiveness of an oral cholera vaccine campaign to prevent clinically-significant cholera in Odisha State, India. Vaccine. 2015 May 15;33(21):2463-9.

23. Halloran ME, Haber M, Longini IM, Struchiner CJ. Direct and Indirect Effects in Vaccine Efficacy and Effectiveness. American Journal of Epidemiology. 1991 Feb $15 ; 133(4): 323-31$.

24. Khatib AM, Ali M, von Seidlein L, Kim DR, Hashim R, Reyburn R, et al. Effectiveness of an oral cholera vaccine in Zanzibar: findings from a mass vaccination campaign and observational cohort study. The Lancet Infectious Diseases. 2012 Nov;12(11):837-44.

25. Qadri F, Wierzba TF, Ali M, Chowdhury F, Khan Al, Saha A, et al. Efficacy of a SingleDose, Inactivated Oral Cholera Vaccine in Bangladesh. The New England Journal of Medicine. 2016 May 5;374(18):1723-32.

26. Ali M, Emch M, von Seidlein L, Yunus M, Sack DA, Rao M, et al. Herd immunity conferred by killed oral cholera vaccines in Bangladesh: a reanalysis. The Lancet. 2005 Jul 2;366(9479):44-9.

27. Ivers LC, Hilaire IJ, Teng JE, Almazor CP, Jerome JG, Ternier R, et al. Effectiveness of reactive oral cholera vaccination in rural Haiti: a case-control study. Lancet Global Health. 2015 Mar;3(3):e162-8. 
Tables

Table 1. Crude and adjusted vaccine effectiveness estimates

\begin{tabular}{|c|c|c|c|c|c|c|}
\hline & 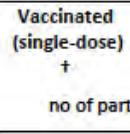 & $\begin{array}{l}\text { Unvaccinated } \\
\text {-ipants (\%) }\end{array}$ & $\begin{array}{c}\text { Crude Vaccine } \\
\text { Effectiveness } \\
\text { (95\% Confidence } \\
\text { Interval) }\end{array}$ & P value & $\begin{array}{c}\text { Adjusted Vaccine } \\
\text { Effectiveness }\end{array}$ & $P$ value \\
\hline \multicolumn{7}{|l|}{ Test-negative analysis } \\
\hline Cholera cases & $3(5)$ & $63(95)$ & Ref & & Ref & \\
\hline Non-cholera diarrhea cases & $39(27)$ & $106(73)$ & $87.1 \%(62.4-97.0)$ & $<0.01$ & ${ }^{*} 80.2 \%(16.9-95.3)$ & 0.03 \\
\hline \multicolumn{7}{|l|}{ Matched case-control analysis } \\
\hline Cholera cases & $3(5)$ & $63(95)$ & Ref & & Ref & \\
\hline Matched controls & $44(13)$ & $286(87)$ & $84.7 \%(27.0-96.6)$ & 0.02 & $\bullet 88.9 \%(42.7-97.8)$ & $<0.01$ \\
\hline \multicolumn{7}{|l|}{ Case-cohort analysis } \\
\hline Cholera cases & $3(5)$ & $63(95)$ & Ref & & Ref & \\
\hline Person time at risk (in days) & 48765.6 & 18826.0 & $86.7 \%(56.6-95.9)$ & $<0.01$ & $+89.4 \%(64.6-96.9)$ & $<0.01$ \\
\hline
\end{tabular}

${ }^{*}$ Test-negative: Vaccine effectiveness adjusted by age, education level, frequency of treating the drinking water and contact (combined variable that considers those who had a household member with cholera in the previous week or shared the drinking water source with a cholera patient as 'exposed'). Living in a vaccinated area was included as a stratification variable in the conditional logistic regression model.

** Matched case-control: Adjusted by contact. Living in a vaccinated area was included as a stratification variable in the regression model.

tCase-cohort: Vaccine effectiveness was adjusted by age, sex, number of children under 5 years of age living in the household, access to safe water, and the place of defecation. 


\subsection{Anexo 2. Listado de enfermedades bajo vigilancia semanal e incluida en el sistema de alerta temprana de Zambia}

Table 1: Suspected and Confirmed Cases and Deaths

IDSR WEEKLY REPORTING FORM

\section{Date of reporting: Reporting Period:}

\begin{tabular}{|c|c|c|c|c|}
\hline Epid-Week: & & Month: & & Year: \\
\hline District : $\quad$ Lusaka & & Province : Lusaka & & Population: \\
\hline Number of HFs: & & $\begin{array}{l}\text { \# of Expected facility } \\
\text { reports: }\end{array}$ & & Target Completeness: $100 \%$ \\
\hline & & $\begin{array}{l}\text { \# of timely facilities } \\
\text { reports: }\end{array}$ & & $\begin{array}{l}\text { \% of Health facility } \\
\text { Timeliness: }\end{array}$ \\
\hline & & \# of late facilities reports : & & $\begin{array}{l}\text { \% of Health Facility } \\
\text { Lateness: }\end{array}$ \\
\hline & & $\begin{array}{l}\text { \# of facility reports } \\
\text { received : }\end{array}$ & & $\%$ of completeness: \\
\hline Disease /Conditions & \# of Cases & Cases Sent to the Lab & $\begin{array}{l}\text { \# of Cases } \\
\text { Confirmed }\end{array}$ & Deaths (\#) \\
\hline AFP & & & & \\
\hline Cholera & & & & \\
\hline Meningitis & & & & \\
\hline Measles & & & & \\
\hline Neonatal Tetanus & & & & \\
\hline Plague & & & & \\
\hline Rabies & & & & \\
\hline Dog bites & & & & \\
\hline Dysentery & & & & \\
\hline Typhoid fever & & & & \\
\hline Yellow fever & & & & \\
\hline VHF & & & & \\
\hline Anthrax & & & & \\
\hline Avian Influenza (H) & & & & \\
\hline Trypanosomiasis & & & & \\
\hline (Bilharzia & & & & \\
\hline Chicken Pox & & & & \\
\hline Food poisoning & & & & \\
\hline Maternal Deaths & & & & \\
\hline Hypertension & & & & \\
\hline Diabetes & & & & \\
\hline Malaria & & & & \\
\hline Trachoma & & & & \\
\hline Diarrhea non bloody & & & & \\
\hline HIV Tests & & & & \\
\hline TB & & & & \\
\hline Leprosy & & & & \\
\hline Snake bite & & & & \\
\hline Mumps & & & & \\
\hline Cervical Cancer & & & & \\
\hline RTA & & & & \\
\hline Pnemonia & & & & \\
\hline TOTAL & & & & \\
\hline
\end{tabular}




\subsection{Anexo 3. Consentimientos informados}

La participación tanto en el estudio de efectividad vacunal como en la encuesta de cobertura vacunal fue informada, asentida y firmada por el participante y/o tutor legal mediante un consentimiento informado, existiendo tres tipos de formularios según la edad del participante:

- Adultos: A partir de 18 años

- Padres/tutores: para los padres o tutores de los menores de 18

- Asentimiento: para los menores entre 14 y 17 años

Para el estudio de efectividad vacunal, los formularios están adaptados en función del diseño del estudio para:

- Casos

- Controles pareados

- Miembros de la cohort

Aquí anexamos los consentimientos usados en los casos del estudio de efectividad vacunal. 


\subsubsection{Formulario de Consentimiento Informado para los casos adultos}

Study Title: The effectiveness of a single-dose of killed whole cell oral cholera vaccine (Shanchol) in an outbreak

Principal Investigator: Drs. Andrew Azman and Francisco Luquero (Johns Hopkins Bloomberg School of Public Health, USA and Epicentre)

IRB No. (JHU): 00006548

Co-Principal Investigator: Dr. Elisabeth Chizema (Ministry of Heath of Zambia)

IRB No. (UNZABREC): 00001131

PI Version, Date: Version 2.0, March 25, 2016

\section{What you should know about this study}

- You are being asked to join a research study.

- This consent form explains the research study and your part in the study.

- I will read it to you and answer any questions that you have. You may also read it yourself and take as much time as you need. Please ask any questions you have as we go through the information.

- You can choose to participate in this study or you can choose to not participate. If you decide to participate, you may change your mind and you may quit at any time.

\section{Purpose of the research}

You are being asked to participate in this research study to better understand how well one dose of oral cholera vaccine protects people from getting cholera. Médecins Sans Frontières and The Ministry of Health of Zambia organized a vaccination campaign to help protect people from getting cholera. The Johns Hopkins Bloomberg School of Public Health and Médecins Sans Frontières are working on this study as part of the follow-up for the vaccination campaign. We hope to learn more about the vaccine so that we can use it in better ways in future outbreaks.

\section{Why are we inviting you to participate in this study?}

You are being asked to be part of this study because you came with diarrhoea to this health clinic and may have cholera.

\section{What is expected from the participants of this research study?}

If you agree to participate in this study, I or another member of my team will ask you questions about your current and past health in addition to simple questions about your age and sex and vaccination history. The questions will take about 20 minutes. We will also ask for a stool sample from you to test for cholera and other factors related to diarrhea. We will also visit your home to ask a few more questions in the coming days but this should take no more than 10 minutes.

\section{Risk and benefits}

There are no benefits to you for participating in this study. However, your participation will help us better understand how well people are protected from cholera after the vaccine and design new ways to use the cholera vaccine.

The results of this study will be presented to the Ministry of Health of Zambia. We will also attempt to keep members of your community informed about the study results. 


\section{Payment}

You will receive a hygiene kit in return for your participation in this study.

Privacy, anonymity and confidentiality

The information you give to the study team will be kept confidential. We will not use your name in any report of the study. Other members of the study team may have access to your personal information. The data from this study may be published. The publication will not contain any names or data that could be used to identify you or any member of your household.

\section{Biological specimens}

The stool sample and data collected from you during this study are important to science and public health. We will use these samples to test for cholera and other things related to diarrhea. Your sample will be stored with a number assigned to it instead of your name and will be shipped to Europe or the United States for testing. You will receive no financial benefit from the use of your sample, but you can request them to be destroyed at any time.

\section{Right not to participate and withdraw}

Participating in the study is voluntary and you do not have to participate if you do not want to. If you agree to join the study now, you can even decide later to withdraw from the study. If you decide to withdraw from the study, we will not use the information you provided. We encourage you to ask questions before you decide to participate in the study. You can get back to us later if you need any other information about the study.

\section{Who do I call if I have questions or problems?}

Please contact the study coordinator with the contact information provided below if you have any questions or concerns about this study. The principal investigators may also be contacted with concerns.

\section{Contact details for research team in Lusaka:}

Name: $\quad$ Cholera Study Coordinator

Address: $\quad$ Médecins Sans Frontières

Plot 7A/377a Chila Road

PlBaeE89L

Box 52 Post net

Lusaka

Tel: +260977403034

\section{Principal investigators:}

Name: $\quad$ Dr. Francisco Luquero

Address: $\quad$ Epicentre

55 Rue Crozatier

75012, Paris, France

Tel: $\quad+\quad+33140215555$

email: $\quad$ Francisco.LUQUERO@epicentre.msf.org

\section{Co-Principal investigator:}

Name: Dr Andrew Azman,

Address: Department of Epidemiology

Johns Hopkins Bloomberg School of Public Health,

615 N. Wolfe Street

Email: $\quad$ azman@jhu.edu 
Telephone: $\quad+41-79.943 .9042$

Fax: $\quad+1-410-614-2632$

If you have questions about your rights in regards to being part of this study, if you feel like you have not been treated fairly, or if you have other concerns you may contact Dr. Ireen Subulwa:

The University Of Zambia

Biomedical Research Ethics Committee

(Unzabrec)

Ridgeway Campus

P.O. Box 50110

Lusaka, Zambia

Telephone: $260-1-256067$

\section{What does your signature on this consent form mean?}

Your signature on this form means (please initial or mark all that you agree to). If you do not mark the three boxes, we will not collect a stool sample from you.

1. Mark if you confirm that you have read or listened to this information sheet for this study, you have asked any questions you have about the study and these questions have been answered.

2. Mark if you understand that your participation is voluntary: you are free to withdraw from the study at any time and do not have to say why. If you withdraw, all information and samples you provided will be destroyed.

3. Mark if you agree to provide a stool sample to be tested for cholera and factors related to diarrhea.

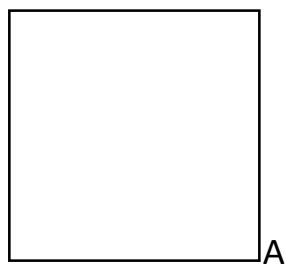

Ask the participant to mark a "left thumb impression" in this box if the participant is unable to provide a signature above. 


\subsubsection{Formulario para los padres/tutores de los casos menores}

Study Title: The effectiveness of a single-dose of killed whole cell oral cholera vaccine (Shanchol) in an outbreak

Principal Investigator: Drs. Andrew Azman and Francisco Luquero (Johns Hopkins Bloomberg School of Public Health, USA and Epicentre)

IRB No. (JHU): 00006548

Co-Principal Investigator: Dr. Elisabeth Chizema (Ministry of Heath of Zambia)

IRB No. (UNZABREC): 00001131

PI Version, Date: Version 2.0, March 25, 2016

\section{What you should know about this study}

- You are being asked to allow your child to join in a research study.

- This consent form explains the research study and your child's part in the study.

- I will read it to you and answer any questions that you or your child may have. You may also read it yourself and take as much time as you need. Please ask any questions you have as we go through the information.

- You can choose to allow your child to participate in this study or you can choose not to allow her or him to participate. If you decide to allow her or him to participate, you may change your mind and ask that they quit at any time.

- We will explain the study to your child and if they are 14years or older, we will ask them if they agree to participate in addition to asking you to allow them to participate.

\section{Purpose of the research}

Your child is being asked to participate in this research study to better understand how well one dose of oral cholera vaccine protects people from getting cholera. Médecins Sans Frontières and The Ministry of Health of Zambia organized a vaccination campaign to help protect people from getting cholera. The Johns Hopkins Bloomberg School of Public Health and Médecins Sans Frontières are working on this study as part of the follow-up for the vaccination campaign. We hope to learn more about the vaccine so that we can use it in better ways in future outbreaks.

\section{Why are we inviting your child to participate in this study?}

We are asking that you allow your child to be part of this study because she/he presented with diarrhea to a clinic treating cholera patients.

\section{What is expected from the participants of this research study?}

If you agree to allow your child to participate in this study, I or another member of my team will ask you and/or your child questions about his or her current and past health in addition to a few basic questions. The questions will take about 20 minutes. We will also ask for a stool sample from your child. We will also visit your home to ask a few more questions in the coming days but this should take no more than 10 minutes.

\section{Risk and benefits}

There are no benefits to your child for participating in this study. However, your child's participation will help us better understand how well people are protected from cholera after the vaccine and design new ways to use the cholera vaccine. 
The results of this study will be presented to the Ministry of Health of Zambia. We will also attempt to keep members of your community informed about the study results.

\title{
Payment
}

Your child will receive a hygiene kit in return for his/her participation in this study.

\section{Privacy, anonymity and confidentiality}

The information you and your child give to the study team will be kept confidential. We will not use his or her name in any report of the study. Other members of the study team may have access to his or her personal information. The data from this study may be published. The publication will not contain any names or data that could be used to identify your child nor any member of your household.

\section{Biological specimens}

The stool samples and data collected from your child during this study are important to science and public health. We will use these samples to test for cholera and other factors related to diarrhea. Your child's samples will be stored with a number assigned to it instead of your child's name and will be shipped to Europe or the United States for testing. You or your child will receive no financial benefit from the use of these samples, but you or your child can request them to be destroyed at any time.

\section{Right not to participate and withdraw}

Participating in the study is voluntary and your child does not have to participate if you or he/she does not want to. If you agree to allow your child to join the study now, you can even decide later to withdraw him or her from the study. If you decide to withdraw your child from the study, we will not use the information your child provided to us. We encourage you to ask questions before you decide whether your child should participate in the study. You can get back to us later if you need any other information about the study.

\section{Who do I call if I have questions or problems?}

Please contact the study coordinator with the contact information provided below if you have any questions or concerns about this study. The principal investigators may also be contacted with concerns.

\author{
Contact details for research team in Lusaka: \\ Name: Cholera Study Coordinator \\ Address: $\quad$ Médecins Sans Frontières \\ Plot 7A/377a Chila Road \\ PlBaeE89L \\ Box 52 Post net \\ Lusaka \\ Tel: $\quad$ +260977403034

\section{Principal investigators} \\ Name: $\quad$ Dr. Francisco Luquero \\ Address: $\quad$ Epicentre \\ 55 Rue Crozatier \\ 75012, Paris, France
}

Tel: $\quad++33140215555$

email: $\quad$ Francisco.LUQUER0@epicentre.msf.org

\section{Co-Principal investigator}




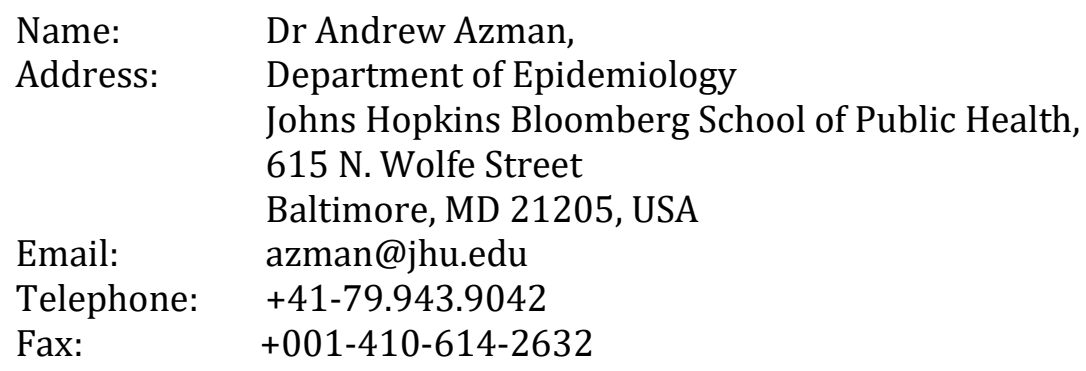

If you have questions about your child's rights in regards to being part of this study, if you feel like you or your child have not been treated fairly, or if you have other concerns you may contact Dr. Ireen Subulwa:

The University Of Zambia

Biomedical Research Ethics Committee

Ridgeway Campus

P.O. Box 50110

Lusaka, Zambia

Telephone: 260-1-256067

\section{What does your signature on this consent form mean?}

Your signature on this form means (please initial or mark all that you agree to). If you do not mark all 4 boxes, we will not collect a stool sample from your child.

4. Mark if you confirm that you have read or listened to this information sheet for this study, you have asked any questions you have about the study and these questions have been answered.

5. I am the legal guardian or parent of the child named below

6. Mark if you understand that your child's participation is voluntary: you are free to withdraw your consent for their participation in the study at any time and do not have to say why. If you withdraw your consent, all information your child provided will be destroyed.

7. Mark if you agree to allow your child to provide a stool sample to be tested for cholera and other factors related to diarrhea

\section{Assent Statement}

Print name of child participant

This research study has been explained to my child in my presence in language my child can understand. He/she has been encouraged to ask questions about the study now and at any time in the future.

Print name of Parent/Guardian

(for children $<18$ years)
Signature of Parent/Guardian - Date

Ask the guardian to mark a "left thumb impression" in this box if the parent/guardian is unable to provide a signature above. 


\subsubsection{Formulario de Asentimiento Informado para los menores maduros}

Study Title: The effectiveness of a single-dose of killed whole cell oral cholera vaccine (Shanchol) in an outbreak

Principal Investigator: Drs. Andrew Azman and Francisco Luquero (Johns Hopkins Bloomberg School of Public Health, USA and Epicentre)

IRB No. (JHU): 00006548

Co-Principal Investigator: Dr. Elisabeth Chizema (Ministry of Heath of Zambia)

IRB No. (UNZABREC): 00001131

PI Version, Date: Version 2.0, March 25, 2016

\section{Are you 14 years or older but less than 18 years old?}

If no, assent should not be taken.

If yes, proceed with reading the following:

\section{Statement to be read to child in the presence of their parent of guardian:}

A disease called cholera can make people sick. There is a vaccine that you may have been given to help make sure you don't get sick from cholera. Some people who get the vaccine may still get cholera though. We want to learn how often this happens and how to make sure all kids and adults are safe.

If you agree to help us, we will ask you some questions. The questions will take about 20 minutes. If you do not want to answer any question, you do not have to. If you want to stop at any time, tell us and we will stop.

If case:

We would like to test your poop to see if the diarrhea you have is cholera and to look for other things that may be related to diarrhea. A nurse will take a sample from your poop bucket so it will not bother you.

Your parent/guardian has said that it would be all right for you to take part in this study, but it is your decision. If you decide to be in the study now, you can change your mind later. You can ask me any questions you want. We will keep all the information you give to us private.

If you sign or mark this paper, it means that you understand what I have said and that you want to be in the study. If you don't want to be in the study, don't sign this paper. Being in the study is up to you, and no one will be upset if you don't sign this paper or if you change your mind later.

The above statement has been read to the child and the child agrees to participate in the research project.

Print Child's Name

Date
Signature or Left Thumb Impression of

Child 
ANEXOS | 262

Print name of

Signature of Parent/Legal Guardian

Date

Parent/Legal Guardian

Print Name Person Obtaining Date

Consent

Consent

Signature of Person Obtaining

Consent 
10.4 Algoritmo para la confirmación por PCR.

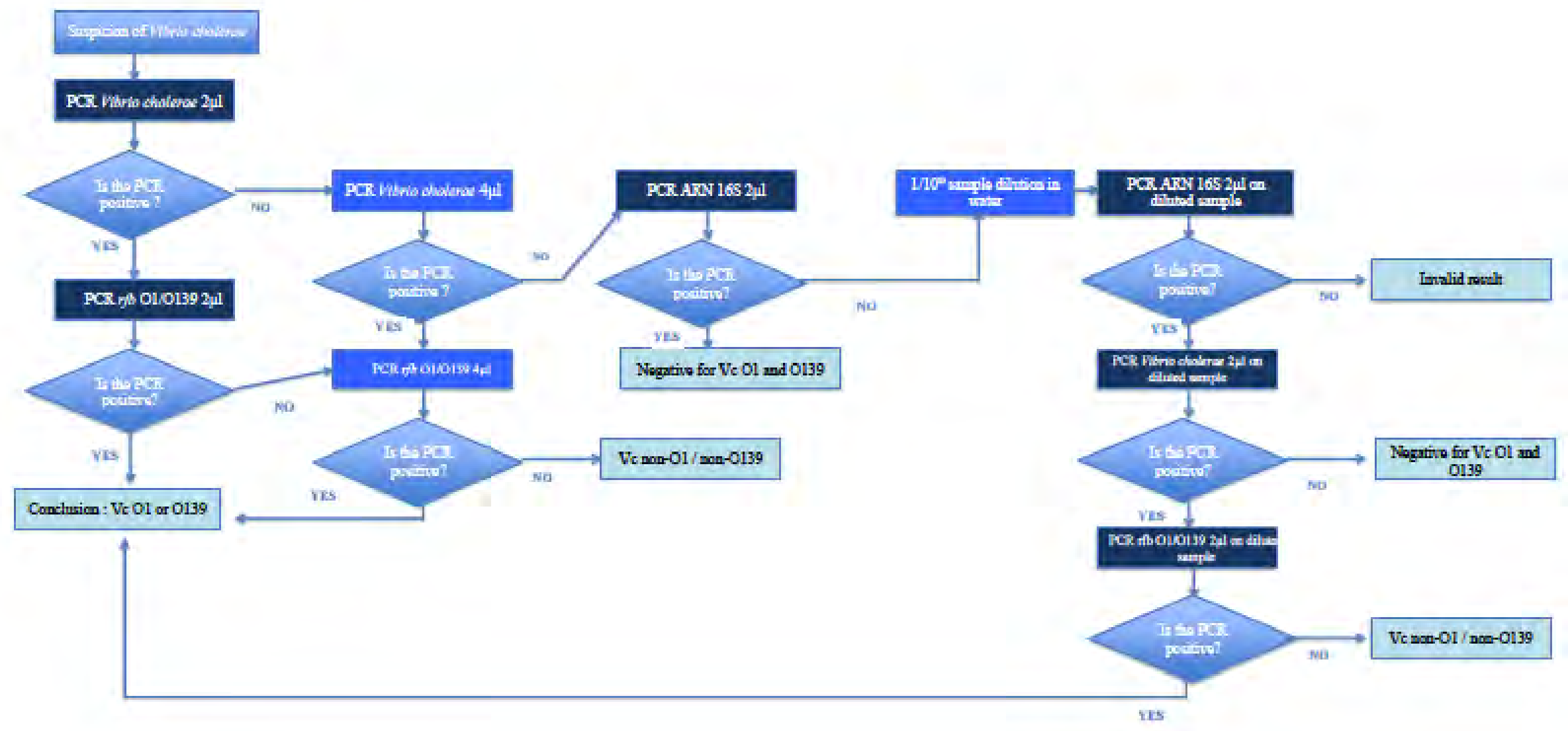


ANEXOS | 264

10.5 Anexo 5. Cuestionarios 
10.5.1 Cuestionario general estudio de eficacia vacunal

\section{The effectiveness of a single-dose of killed whole cell oral cholera vaccine (Shanchol) in an outbreak}

\begin{tabular}{|llr|}
\hline \multicolumn{1}{|c|}{ IDENTIFICATION OF THE HEALTH FACILITY } & \\
X1 & PlACE WHERE THE QUESTIONNAIRE WAS COMPLETED: & PARTICIPANT'S HOME [_] \\
& & BAULEN CTC [_] \\
& KANYAMA CTC ([_] \\
X2 & MATERO CTC [_] \\
& DATE OF COMPLETION, (TODAY DATE): & (dd/mm/yyy) \\
X3 $\quad$ Name of interviewer & \\
\hline
\end{tabular}

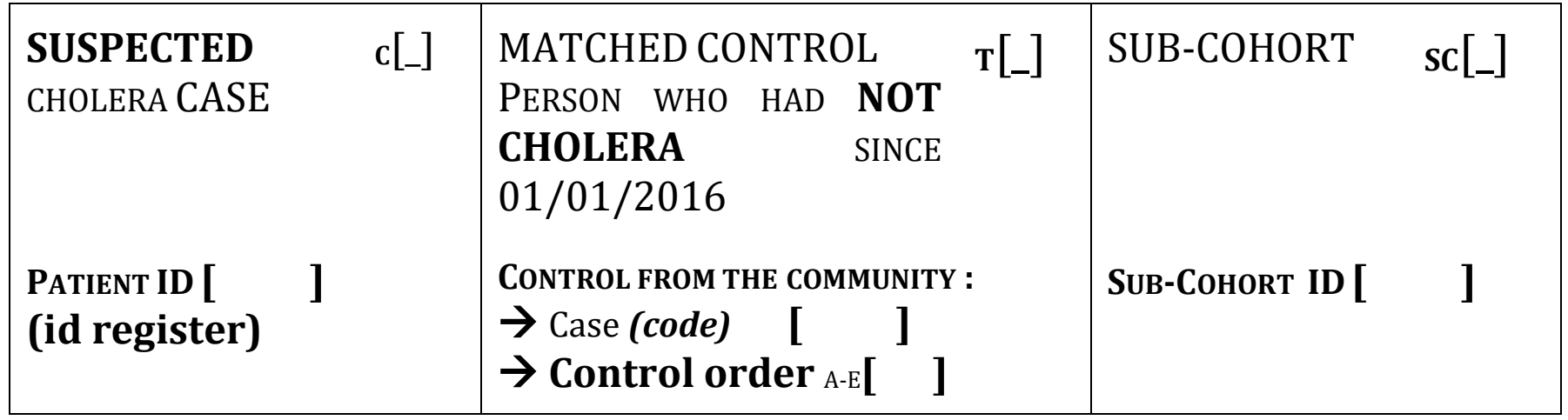

\section{IDENTIFICATION (to be completed for the case and the controls)}

X7 SEX :

X8 AGE:

X9 SPECIFy ADDRESS (AND VillaGE):

X10 PHONE NumBer:

$$
\text { (10 DIGITS) }
$$




\begin{tabular}{|c|c|c|c|c|}
\hline \multirow[t]{2}{*}{ B } & \multicolumn{4}{|l|}{ SUSPECTED CHOLERA PATIENTS } \\
\hline & \multicolumn{4}{|c|}{ INFORMATION COLLECTED DURING THE CONSULTATION IN THE HEALTH FACILITY } \\
\hline B1 & \multicolumn{3}{|c|}{$\begin{array}{l}\text { Identification number of the suspected case in the cholera [ } \\
\text { register }\end{array}$} & ] \\
\hline B2 & \multicolumn{3}{|c|}{ Date of admission at the CTC $\quad \ldots \ldots . . . . \ldots . .}$. & ........... \\
\hline B3 & \multicolumn{2}{|l|}{ Date of diarrhea onset } & \multicolumn{2}{|c|}{$\ldots \ldots / \ldots \ldots \ldots / \ldots \ldots \ldots . .}$. \\
\hline B4 & \multicolumn{2}{|l|}{ Type of diarrhea: } & \multicolumn{2}{|c|}{$\begin{array}{l}\text { Watery } 1[-] \\
\text { Bloody } 2[] \\
\text { Other } 3[-]\end{array}$} \\
\hline B5 & \multicolumn{4}{|l|}{ Dehydration: } \\
\hline B6 & \multicolumn{2}{|l|}{ The patient is still admitted in the CTC: } & \multicolumn{2}{|c|}{ Yes 1 [_] No o[_] } \\
\hline B7 & \multicolumn{2}{|l|}{ If « No », date of discharge: } & \multicolumn{2}{|c|}{................../2016 } \\
\hline B8 & $\begin{array}{l}\text { Did the patient receive antibiotics in the CTC } \\
\text { before the sample was collected? }\end{array}$ & Yes 1 [_] No o[_] & \multicolumn{2}{|c|}{ Don't Know 9[_] } \\
\hline \multirow[t]{3}{*}{ B9 } & $\begin{array}{l}\text { Did patient take antibiotics within the past } 2 \\
\text { days before arriving at the center? }\end{array}$ & Yes 1[_] No o[_] & Don’t Kr & $\mathrm{W} 9$ [_] \\
\hline & \multicolumn{4}{|l|}{ INCLUSION CRITERIA } \\
\hline & & & Yes & No \\
\hline B9 & \multicolumn{2}{|c|}{$\begin{array}{l}\text { Have you had at least three watery stools in } 24 \text { hours since the } \\
\text { onset of diarrhea? }\end{array}$} & $1[$ [ $]$ & ${ }_{0}[$ [_] \\
\hline B10 & \multicolumn{2}{|l|}{ Did the diarrhea start after $11 / 04 / 2016 ?$} & 1 [_] & ${ }_{0}[$ [_] \\
\hline B11 & \multicolumn{2}{|c|}{ Was the patient 12 months or older on $01 / 04 / 2016 ?$} & ${ }_{1}[$ [] & ${ }_{0}[$ [_] \\
\hline B12 & \multicolumn{2}{|c|}{$\begin{array}{l}\text { Has the patient resided in the same household for at least the } \\
\text { past two weeks? }\end{array}$} & 1 [_] & ${ }_{0}[$ [_] \\
\hline B13 & \multicolumn{2}{|c|}{$\begin{array}{l}\text { Has the patient (and/or guardian) provided informed consent to } \\
\text { participate? }\end{array}$} & 1[_] & ${ }_{0}[$ [_] \\
\hline \multicolumn{5}{|c|}{ ATtENTION : } \\
\hline
\end{tabular}




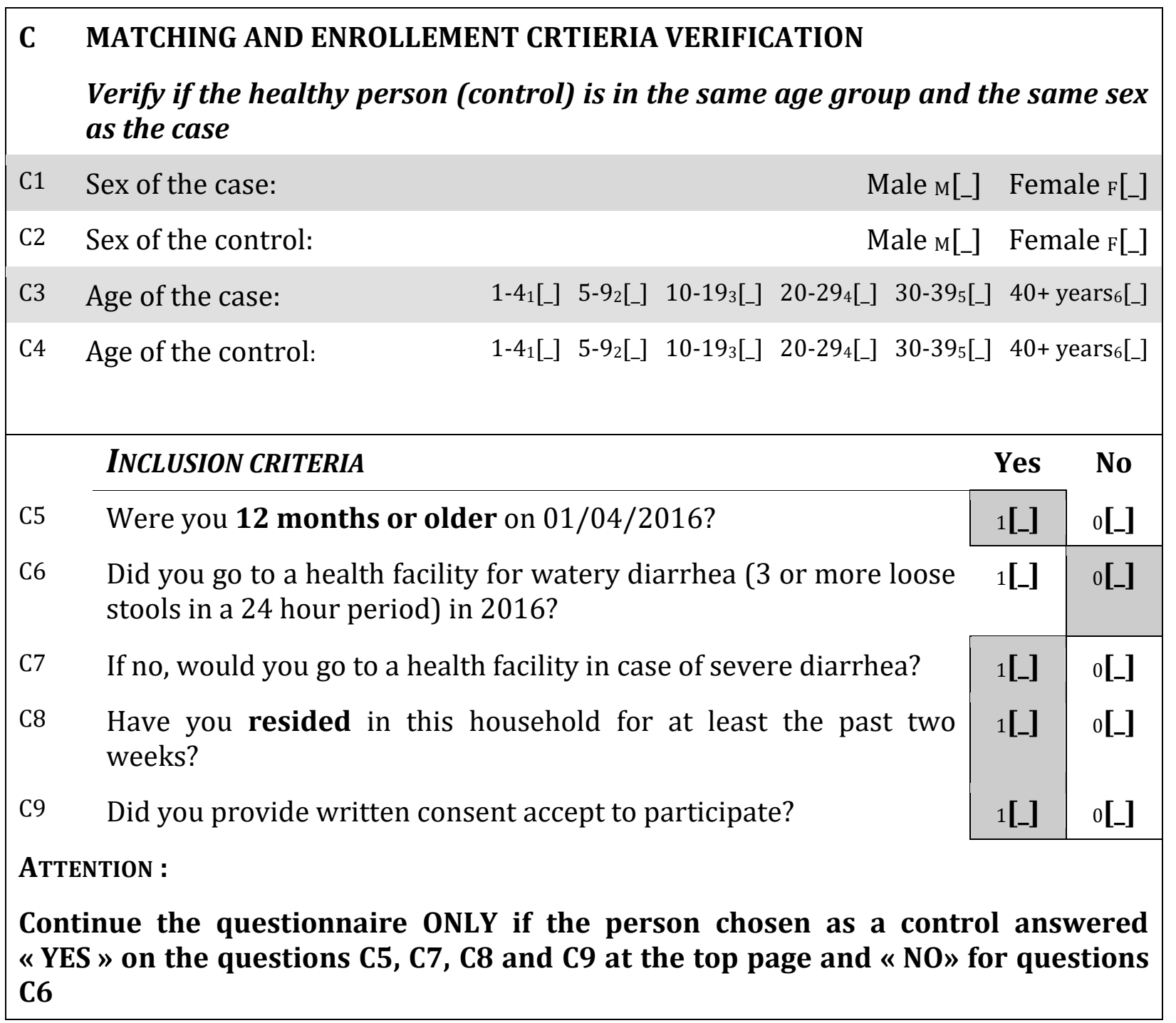

\begin{tabular}{|c|c|c|c|}
\hline CA & \multicolumn{3}{|l|}{ COHORT ENROLLEMENT CRTIERIA VERIFICATION } \\
\hline & \multicolumn{3}{|l|}{ INCLUSION CRITERIA } \\
\hline & & Yes & No \\
\hline Ca1 & Were you 12 months or older on $01 / 04 / 2016 ?$ & 1 [_] & ${ }_{0}[-]$ \\
\hline $\mathrm{Ca} 2$ & $\begin{array}{l}\text { Did you go to a health facility for watery diarrhea ( } 3 \text { or more loose } \\
\text { stools in a } 24 \text { hour period) in } 2016 ?\end{array}$ & $1[$ [_] & 0 [_] \\
\hline $\mathrm{Ca} 3$ & If no, would you go to a health facility in case of severe diarrhea? & 1 [_] & ${ }_{0}[-]$ \\
\hline $\mathrm{Ca} 4$ & $\begin{array}{l}\text { Have you resided in this household for at least the past two } \\
\text { weeks? }\end{array}$ & 1 [_] & 0 [_] \\
\hline $\mathrm{Ca} 5$ & Did you provide written consent accept to participate? & 1 [_] & ${ }_{0}[-]$ \\
\hline \multicolumn{4}{|c|}{ ATTENTION : } \\
\hline \multicolumn{4}{|c|}{$\begin{array}{l}\text { Continue the questionnaire ONLY if the person answered «YES » on the questions } \\
\text { Ca1, Ca3, Ca4 and Ca5 and « NO» for question Ca2 }\end{array}$} \\
\hline
\end{tabular}




\begin{tabular}{|c|c|c|}
\hline A & RESIDENCE & \\
\hline $\mathbf{A 1}$ & When did you arrive to Lusaka? & 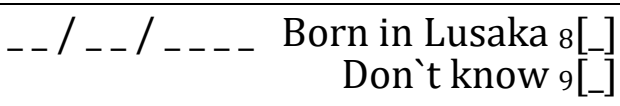 \\
\hline A2 & If unknown, did you arrive in $2016 ?$ & Yes 1[_] No o[_] Don't Know 9[_] \\
\hline A3 & What Country or Province in Zambia did you & \\
\hline
\end{tabular}

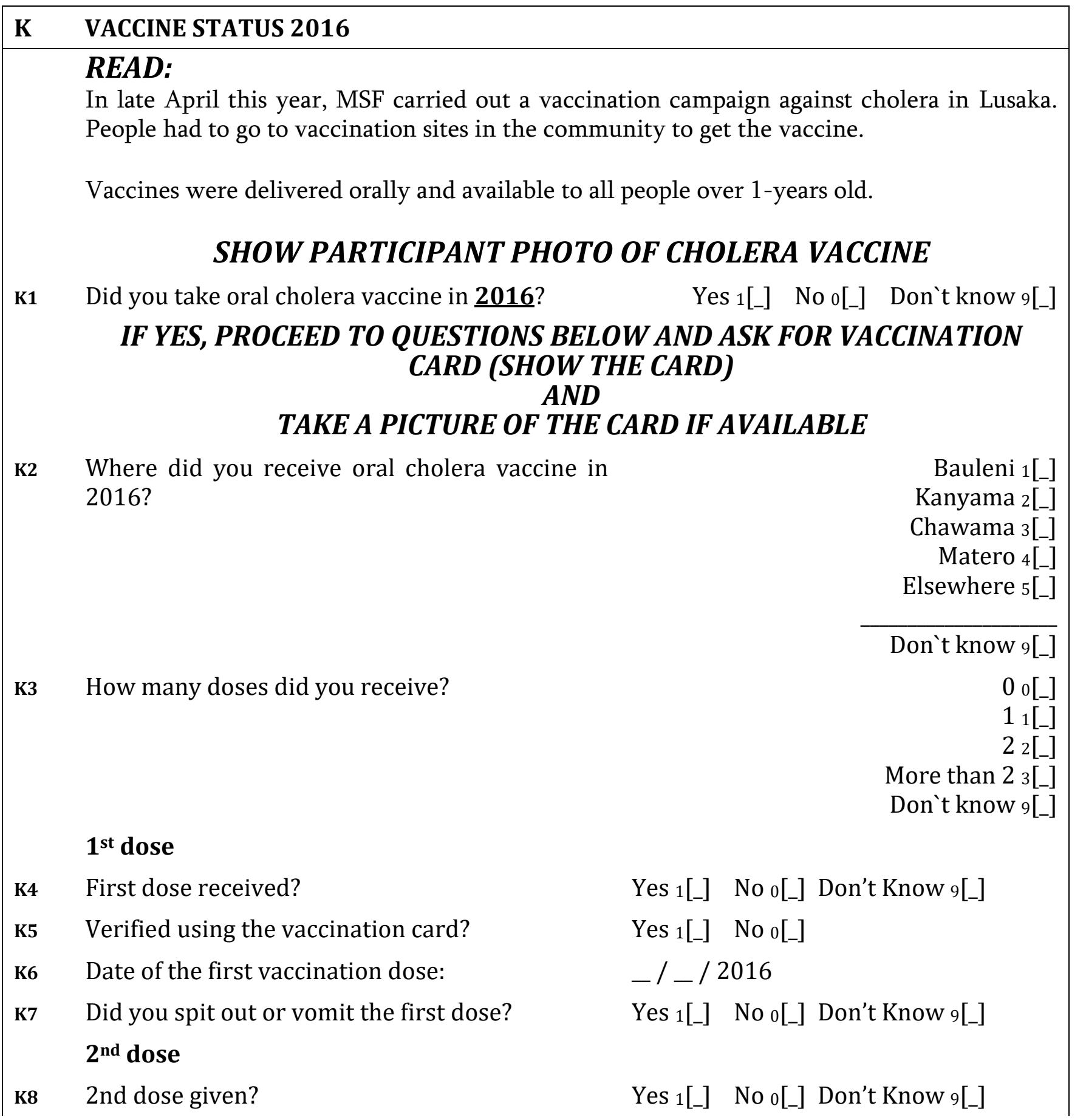


к9 Verified using the vaccination card?

K10 Date of the second vaccination dose:

K11 Did you spit out or vomit the second dose? $3^{\text {rd }}$ dose

K12 3rd dose given?

K13 Verified using the vaccination card?

K14 Date of the third vaccination dose :

K15 Did you spit out or vomit the third dose?

K16 Did you receive a hygiene kit with soap and water treatment supplies at the same time you got vaccine?

K17 Did anyone explain how to use the soap and/or water treatment supplies at the time you were vaccinated?

K18 Did anyone discuss how to prevent cholera and/or diarrhea with you at the time you were vaccinated?
Yes 1[_] No 0[_]

- /_ / 2016

Yes 1[_] No 0[_] Don't Know 9[_]

Yes 1[_] No 0[_] Don't Know 9[_]

Yes 1[_] No 0[_]

_/_ / 2016

Yes 1[_] No 0[_] Don't Know 9[_]

Yes 1[_] No 0[_] Don't Know 9[_]

Yes 1[_] No 0[_] Don't Know 9[_]

Yes 1[_] No 0[_] Don't Know 9[_]

\section{SOCIO ECONOMIC STATUS}

D1 What is your current job?

Vendor 1 [_]

Community Health Worker 2[_] Medical staff 3 [_] Pupil/student/child 4[_] Cleaner 5[_] No work 6[_] Others 7[_] Don`t know 9[_]

D2 What is the highest education None (illiterate) 0 [_] level you have achieved? None (literate) 1 [_] Primary school 2[_] Secondary school 3[_] University (or higher) 4 [_] Don`t know/don`t remember 9[_]

D3 Does your household have?
(read the questions one by on $)$

Radio Motorbike Mobile phone Generator Television Fridge Oven
Yes 1[_] No 0[_] Don't Know 9[_] Yes 1[_] No 0[_] Don't Know 9[_] Yes 1[_] No 0[_] Don't Know 9[_] Yes 1[_] No 0[_] Don't Know 9[_] Yes 1[_] No 0[_] Don't Know 9[_] Yes 1[_] No 0[_] Don't Know 9[_] Yes 1[_] No 0[_] Don't Know 9[_] 


\begin{tabular}{|c|c|c|}
\hline D4 & $\begin{array}{l}\text { How many people live currently in the household } \\
\text { (including you)? }\end{array}$ & [_- ] Don't know 9[_] \\
\hline D5 & How many children less than 5 years old? & [_-_ Don't know 9[_] \\
\hline D6 & $\begin{array}{l}\text { How many children less than } 5 \text { years old are } \\
\text { vaccinated against measles? }\end{array}$ & Don't know 9[_] \\
\hline D7 & How many children between 5 and 15 years old? & Don't know 9[_] \\
\hline D8 & How many children between 5 and 15 go to school? & [__] Don't know 9[_] \\
\hline
\end{tabular}

\begin{tabular}{|ll|}
\hline E & ACCESS TO HEALTH CARE \\
\hline E1 & $\begin{array}{l}\text { If you had severe diarrhea, where would you } \\
\text { go first to get treatment? } \\
\text { List in order the way the person tells you }\end{array}$ \\
& \\
E2 & $\begin{array}{l}\text { Which means of transport would you use to } \\
\text { go there? }\end{array}$
\end{tabular}

E3 How much time does it take you to go to there?

\section{Hospital 1[_] Health Center (PHCC) 2[_] Oral Rehydration Post $3[$ [_] Cholera Treatment Center 4[_] Traditional Healer 5[_] Private Clinic 6[_] Nowhere (would stay at home) $7[$ [_] Others 8[_] Yes 1[_] No 0[_] Don't Know 9[_] By foot 1 [_] Bicycle 2[_] Motorbike 3[_] Car 4[_] Public transport 5[_] Others 6[_] \\ Don't know 9[_] minutes}

\section{F HISTORY OF CHOLERA AND CONTACTS WITH SUSPECTED CASES}

F1 At this moment, does anyone in your household have cholera?

F2 Did any of your family members (excluding you) suffer from Yes 1[_] No 0[_] Don`t know/remember 9[_] cholera during the last week?

F3 Did any of your neighbors or friends suffer from cholera during the last week?

F4 Have you participated in a burial or funeral of someone suspected to have cholera during the last week?

\section{G WATER SOURCE AND STORAGE}

G1 What was the main source of drinking water for your household 
during the last week?

(Tick the case, do not suggest the various possible answer(s))
Natural source (river, stream, lake, pond) 3[_]

Borehole 4 [_]

Shallow well 5[]

Factory filled bottle 6[_] Locally re-filled bottle $7[$ [_]

Other 8 [_]

Don`t know 9[_]

No 0[_] At least one day 1[_] Every day 2[_] Don`t know 9[_]

Chlorination 1[_] Boiling 2[_] Filter 3 [_] Other 4[_] Don't know 9[_]

Yes 1[_] No o[_]

Doesn't Store Drinking Water 3[_] Don`t know 9[_]

Yes 1[_] No o[_]

Don`t know 9[_] Not applicable (alone) 8[_] cholera during the last week?

\section{H FOOD CONSUMED DURING THE LAST WEEK}

H1 Have you consumed food or drink (i.e. fresh juice) prepared in the Never 0[_] At least once 1[_] Every day 2[_] market or by a street vendor during Don`t know $9\left[\_\right]$ the past week?

\section{HYGIENE PRACTICE}

I1 Do you have soap (for hand washing) in the household at present?

2 When do you usually wash your hands?

(Don't suggest the answers, cross only the ones mentioned by the participant).

Yes 1[_] No o[_]

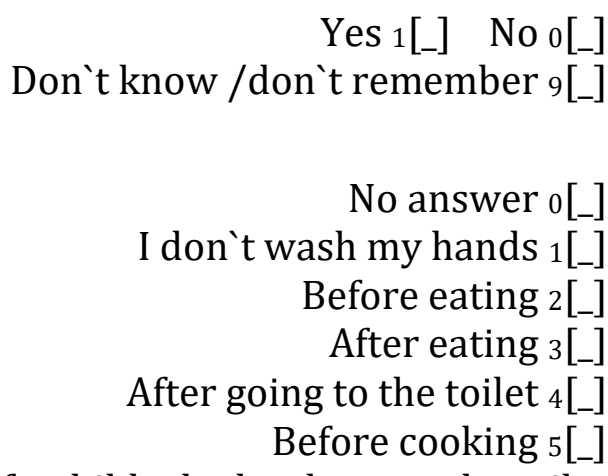

After taken care of a child who has been to the toilet

$6[$ [_]

Others $8[-]$

\section{J TOILETS/LATRINES}

J1 Where do you normally defecate?
None, defecation is done anywhere outside 1 [_]

Toilet inside the house 2 [_]

Latrine in common use (shared by several families) 3[_]

Locked latrine (few families) 4 [_]

Hole (no cement) 5[_]

Container or plastic bag 6[_] 
ANEXOS | 272

\begin{tabular}{|c|c|c|c|}
\hline & & & Otherg [_] \\
\hline $\mathrm{J} 2$ & $\begin{array}{l}\text { Do you have a toilet/latrine in } \\
\text { your house or on your } \\
\text { property? }\end{array}$ & & Yes 1[_] No o[_] \\
\hline $\mathbf{J} 3$ & $\begin{array}{l}\text { Did anyone you share your } \\
\text { latrine with suffer from severe } \\
\text { diarrhea during the last week? }\end{array}$ & Don`t know 9[_] & $\begin{array}{cc}\text { Yes 1[_] } & \text { No o[_] } \\
\text { Not applicable (NA) } 8[-]\end{array}$ \\
\hline $\mathbf{J 4}$ & Is the latrine flooded? & Not possible to see $\left.{ }_{3}[]\right]$ & $\begin{array}{c}\text { Yes 1[_] No 0[_] } \\
\text { NA 8[_] } \\
\text { Don`t know 9[_] }\end{array}$ \\
\hline
\end{tabular}

\section{THANK YOU!}

GPS COORDINATES OF THE HOUSEHOLD: LAT:N LONG: W

PERSON FILLING THE QUESTIONNAIRE

Name:

Signature:

SUPERVISOR

Name:

Signature: 
10.5.2 Cuestionario de seguimiento de la cohorte

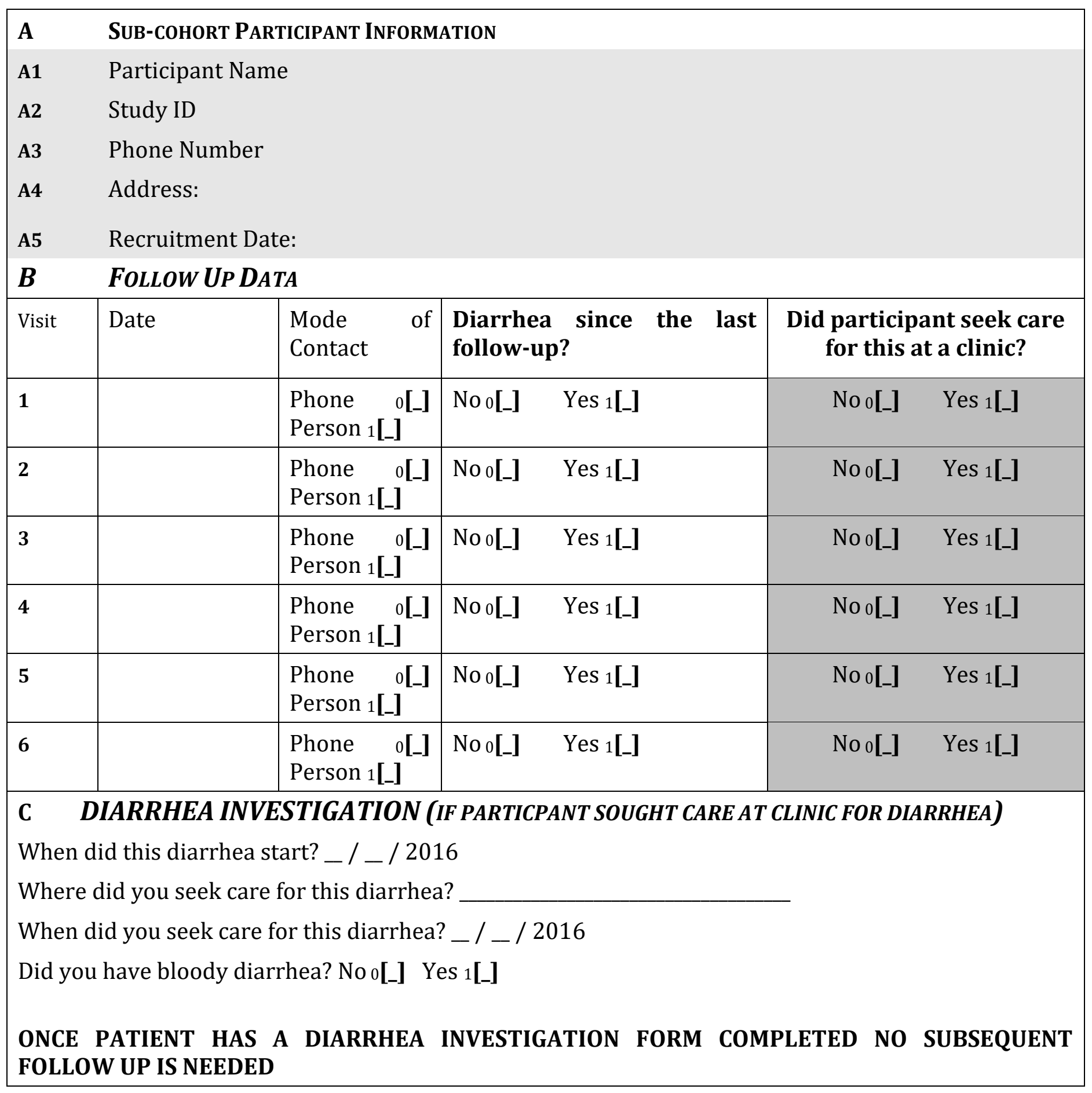


10.5.3 Cuestionario de la encuesta de cobertura vacunal

Post-campaign vaccination coverage survey following the administration of the second dose of oral cholera vaccine in Lusaka, Zambia

\section{BASICS}

X2 DATE OF COMPLETION, (TODAY DATE):

X3 Name of interviewer

X4 Assigned GPS ID

\section{IDENTIFICATION}

X7 SEX :

MALE ${ }_{\text {m[_] }}$

FEMALE F[_]

X8 AGE:

[ ] YEARS

X9 SPECIFY ADDRESS (AND VILLAGE):

X10 PHONE Number:

$$
\text { (10 DIGITS) }
$$




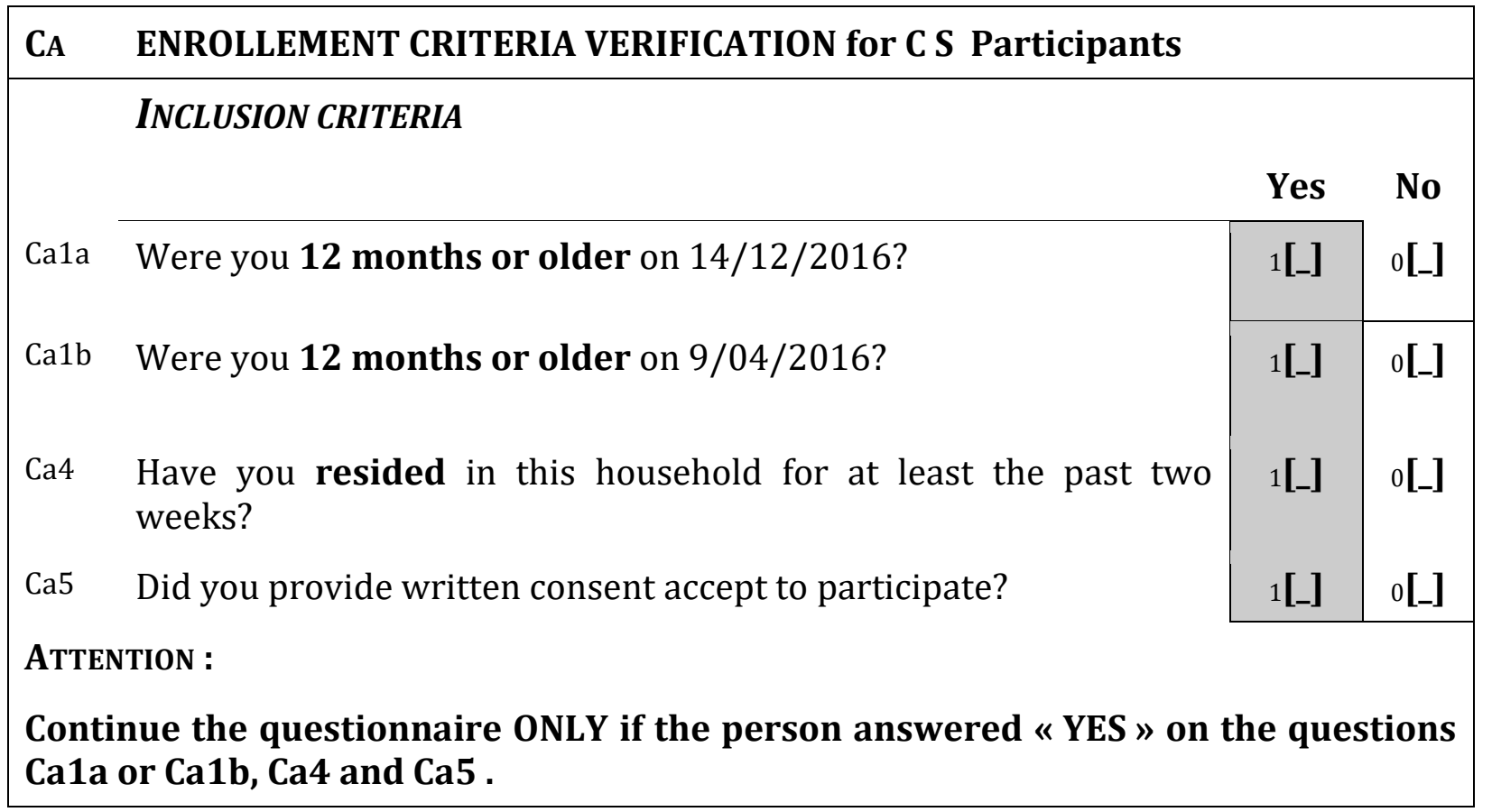

\begin{tabular}{|llr|}
\hline E & EDUCATIONAL LEVEL & \\
\hline E1 & What is the highest education level you have & None (illiterate) $0\left[\_\right]$ \\
& achieved? & None (literate) 1[_] \\
& Primary school 2[_] \\
& Secondary school $3\left[\_\right]$ \\
& & University (or higher) 4[_] \\
& & \\
& & \\
& & \\
& & \\
\end{tabular}

\section{K VACCINE STATUS DECEMBER 2016 CAMPAIGN}

\section{READ:}

In december 2016, Ministry of Health carried out a vaccination campaign against cholera in Lusaka. People had to go to vaccination sites in the community to get the vaccine.

Vaccines were delivered orally and available to all people over 1-years old.

\section{SHOW PARTICIPANT PHOTO OF CHOLERA VACCINE}

K1 Did you take oral cholera vaccine in December 2016?

Yes 1[_] No o[_] Don't know 9[_]

\section{IF YES, PROCEED TO QUESTIONS BELOW AND ASK FOR VACCINATION CARD (SHOW THE CARD) AND \\ TAKE A PICTURE OF THE CARD IF AVAILABLE}


K1b Why participant hasn't received a vaccination card? (if K1a=no)

K1c Does participant have vaccination card?

K1d Can you show me your vaccination card?

K1e Reasons for not be able to show vaccination card (If $k 1 d=n o$ )

K2 Reason for not taking the vaccine (If $K 1=$ no)

\section{Yes 1[_] No 0[_] \\ Yes ${ }_{1}[$ ] No 0 [_]}
Misplace/ lost 0 [_] Destroyed/ threw away1[_]
Other 9[_]

There was no vaccination campaign where she/he lived o[_]

Did not know there was another vaccination campaign ${ }_{1}$ [_]

Thought he/she wasn't eligible 2[_]

Did not know the date of the campaign3[_] Did not know the location of the campaign

Refusal because of tradition 5[_]

Refusal because of religious beliefs6[_] The vaccine is considered dangerous7[_]

Wait considered too long [_] $_{3}$ Vaccination site deemed too far 9[_] There was not enough vaccine in the vaccination sites 10 [_]

Absent during the campaign 11 [_] Did not have time12[_]

Was ill during the vaccination campaign 13[_] Bad experiences with other vaccines in the past 14[_]

Hospitalized at the time of the vaccination campaign15[_]

The vaccinator refused to give the person vaccine 16[_] Decided not to get vaccinated because she was pregnant 17[_]

Taste is bad18[_] No explanation 19 [_]

Other $20[-]$

K3 Where did you receive oral cholera vaccine in december 2016?
Bauleni 1[_] Kanyama 2[_] Chawama 3[_] George 4[_] 
K5 Did you spit out or vomit the second dose?

Did anyone discuss how to prevent cholera K6 and/or diarrhea with you at the time you were vaccinated?

K7 Verified using the vaccination card?

к8 Date of the second vaccination dose :

K8a

K8b
Fever ${ }_{1}\left[\_\right]$ Diahorrea 2[_] Abdominal pain 3[_] Nausea 4[_] Vomiting 5[_] Headache 6[_] General weakness 7[_] Other (especify)8[_]

K8c Did you go to a health facility or vaccination post Yes 1[_] No o[_] Don't Know 9[_] after feeling unwell?

K8d Where did you seek care for this adverse event? (if $K 8 \mathrm{c}=\mathrm{Yes}$ )

\section{H VACCINE STATUS APRIL 2016 CAMPAIGN}

\section{READ:}

In April 2016, Ministry of Health with Medecins sans Frontieres carried out a vaccination campaign against cholera in Lusaka. People had to go to vaccination sites in the community to get the vaccine.

Vaccines were delivered orally and available to all people over 1-years old.

\section{SHOW PARTICIPANT PHOTO OF CHOLERA VACCINE}

H1 Did you take oral cholera vaccine in April 2016?

Yes 1[_] No 0[_] Don`t know 9[_]

\section{IF YES, PROCEED TO QUESTIONS BELOW AND ASK FOR VACCINATION CARD (SHOW THE CARD) \\ AND \\ TAKE A PICTURE OF THE CARD IF AVAILABLE}


H1b Why participant hasn't received a vaccination card? (if H1a=no)

H1c Does participant have vaccination card?

H1d Can you show me your vaccination card?

H1e Reasons for not be able to show vaccination card (If $H 1 d=n o$ )

H2 Reason for not taking the vaccine (If H1=no)

\section{Yes 1[_] No 0[_] \\ Yes ${ }_{1}[$ ] $\quad$ No 0 [_]}
Misplace/ lost 0 [_] Destroyed/ threw away1[_]
Other 9[_]

There was no vaccination campaign where she/he lived o[_]

Did not know there was another vaccination campaign ${ }_{1}$ [_]

Thought he/she wasn't eligible 2[_]

Did not know the date of the campaign3[_] Did not know the location of the campaign

Refusal because of tradition 5[_]

Refusal because of religious beliefs6[_] The vaccine is considered dangerous7[_]

Wait considered too long [_] $_{3}$ Vaccination site deemed too far 9[_] There was not enough vaccine in the vaccination sites 10 [_]

Absent during the campaign 11 [_] Did not have time12[_]

Was ill during the vaccination campaign 13[_] Bad experiences with other vaccines in the past 14[_]

Hospitalized at the time of the vaccination campaign15[_]

The vaccinator refused to give the person vaccine 16[_] Decided not to get vaccinated because she was pregnant 17[_]

Taste is bad18[_] No explanation 19 [_]

Other $20[-]$

H3 Where did you receive oral cholera vaccine in april 2016?
Bauleni 1[_] Kanyama 2[_] Chawama 3[_] George 4[_] 
H5 Did you spit out or vomit the first dose?

Did anyone discuss how to prevent cholera H6 and/or diarrhea with you at the time you were vaccinated?

H7 Verified using the vaccination card?

H8 Date of the first vaccination dose :

H8a Did you feel any discomfort after taking the Yes 1[_] No 0[_] Don't Know 9[_] vaccine?

H8b What type of symptoms did you feel? (if $8 a=y e s$ )
Yes 1[_] No 0[_] Don't Know 9[_]
Yes 1[_] No 0[_] Don't Know 9[_]

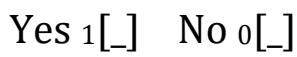

$-/$ / $/ 2016$

Fever 1[_] Diahorrea 2[_] Abdominal pain 3[_] Nausea 4[_] Vomiting 5[_] Headache 6[_] General weakness 7[_] Other (especify)8[_]

H8c Did you go to a health facility or vaccination post Yes 1[_] No 0[_] Don't Know 9[_] after feeling unwell?

H8d Where did you seek care for this adverse event? (if $H 8 \mathrm{c}=\mathrm{Yes}$ )

\section{THANK YOU!}

ENTER ANY COMMENTS ABOUT THE VISIT:

GPS COORDINATES OF THE HOUSEHOLD: LAT:N LONG: W PERSON FILLING THE QUESTIONNAIRE

Name: Signature:

SUPERVISOR

Name: 
ANEXOS | 280 